The Alaska Volcano Observatory is a cooperative program of the U.S. Geological Survey, University of Alaska Fairbanks Geophysical Institute, and the Alaska Division of Geological and Geophysical Surveys. The Alaska Volcano Observatory is funded by the U.S. Geological Survey Volcano Hazards Program and the State of Alaska

\title{
2006 Volcanic Activity in Alaska, Kamchatka, and the Kurile Islands: Summary of Events and Response of the Alaska Volcano Observatory
}

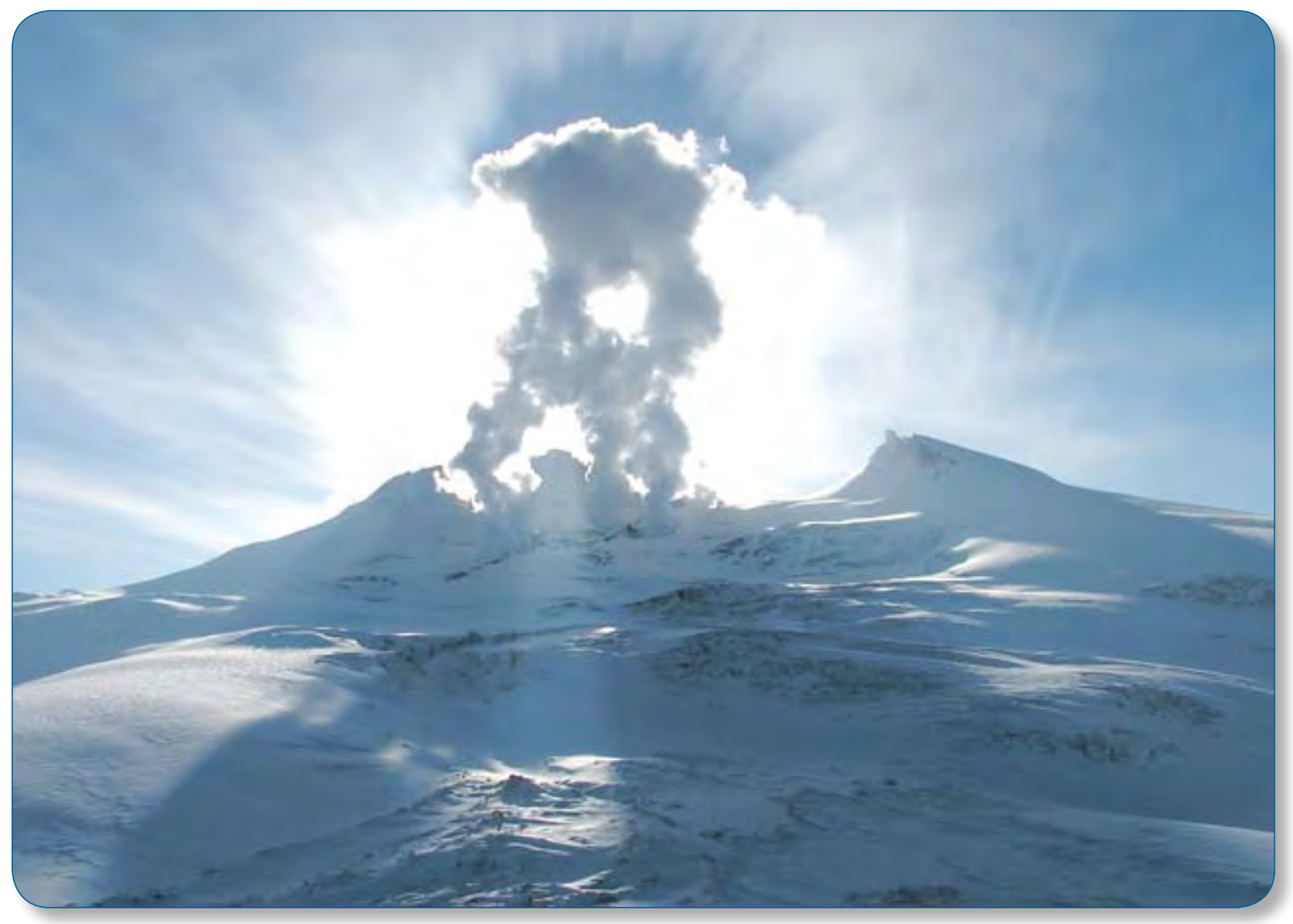

Scientific Investigations Report 2008-5214 
Cover: Water vapor and volcanic gas billows from a line of explosion and/or collapse pits in the glacial ice cover north of the summit of Fourpeaked volcano. In the middleground, glacial ice shows disruption from an outburst flood on September 17, 2006, the day of a phreatic eruption seen from Homer, Alaska. Photograph by K. Lawson, UAFGI, October 20, 2006. AVO database image url: http://www.avo.alaska.edu/image.php?id=12404. 


\section{Volcanic Activity in Alaska, Kamchatka, and the Kurile Islands: Summary of Events and Response of the Alaska Volcano Observatory}

By Christina A. Neal, Robert G. McGimsey, James P. Dixon, U.S. Geological Survey, and Alexander Manevich, Institute of Volcanology and Seismology, and Alexander Rybin, Institute of Marine Geology and Geophysics

The Alaska Volcano Observatory is a cooperative program of the U.S. Geological Survey, University of Alaska Fairbanks Geophysical Institute, and the Alaska Division of Geological and Geophysical Surveys. The Alaska Volcano Observatory is funded by the U.S. Geological Survey Volcano Hazards Program and the State of Alaska.

Scientific Investigations Report 2008-5214

U.S. Department of the Interior

U.S. Geological Survey 


\section{U.S. Department of the Interior DIRK KEMPTHORNE, Secretary}

\section{U.S. Geological Survey \\ Mark D. Myers, Director}

\section{U.S. Geological Survey, Reston, Virginia: 2009}

For product and ordering information:

World Wide Web: http://www.usgs.gov/pubprod

Telephone: 1-888-ASK-USGS

For more information on the USGS — the Federal source for science about the Earth, its natural and living resources, natural hazards, and the environment:

World Wide Web: http://www.usgs.gov

Telephone: 1-888-ASK-USGS

Any use of trade, product, or firm names is for descriptive purposes only and does not imply endorsement by the U.S. Government.

Although this report is in the public domain, permission must be secured from the individual copyright owners to reproduce any copyrighted materials contained within this report.

Suggested citation:

Neal, C.A., McGimsey, R.G., Dixon, J.P., Manevich, Alexander, and Rybin, Alexander, 2009, 2006 Volcanic activity in Alaska, Kamchatka, and the Kurile Islands: Summary of events and response of the Alaska Volcano Observatory: U.S. Geological Survey Scientific Investigations Report 2008-5214, 102 p. 


\section{Contents}

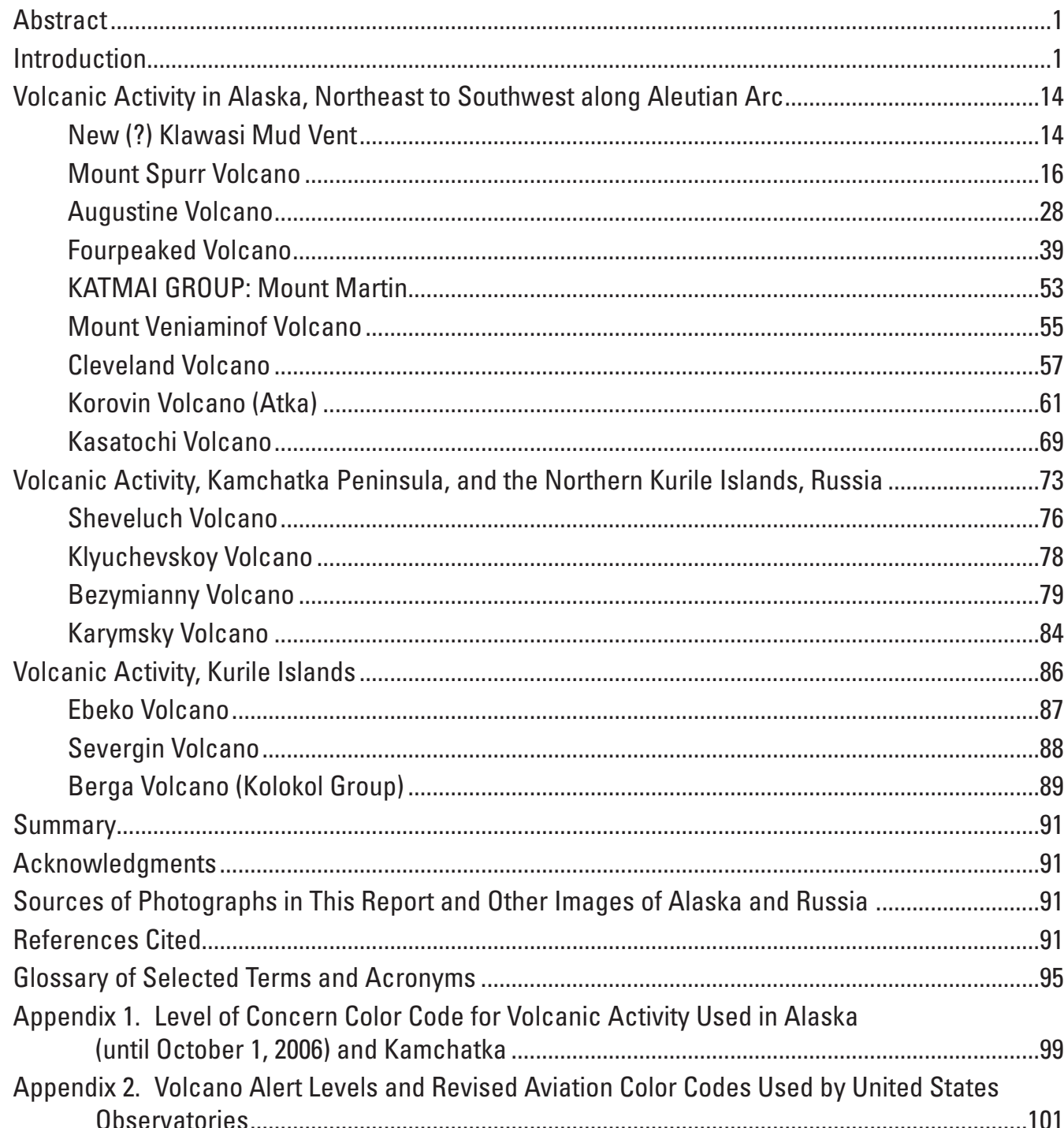




\section{Figures}

Figure 1. Map showing historically active and selected older volcanoes in Alaska along with place names used in this report

Figure 2. Map showing mud volcanoes and possible new mud vent in the Copper River basin

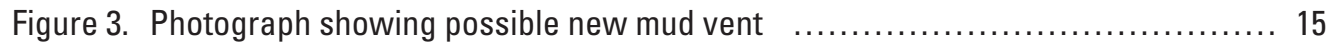

Figure 4. Photograph showing summit ice cauldron at Mount Spurr, March 2006 .......... 19

Figure 5. Forward Looking Infrared Radiometer image mosaic (right) and correlative video frame capture (left) of the north shoreline of the warm lake within the summit ice cauldron

Figure 6. Photograph showing aerial view of Mount Spurr cauldron, April 2006 ........... 21

Figure 7. Photograph showing aerial view of Mount Spurr ice cauldron looking northeast showing area of pressurized fumarolic jets on the sloping crater floor

Figure 8. Photograph showing southeast flank of Mount Spurr summit cone showing slab avalanche

Figure 9. Photographs showing view looking northwest of changes at Mount Spurr summit immediately prior to cauldron opening in June $2004(A)$ to growth of the cauldron to maximum size 2 years later in June $2006(B)$

Figure 10. Photograph showing oblique aerial view of the upper southeast flank of the Mount Spurr summit cone....

Figure 11. Photograph showing southern flank of Mount Spurr volcanic complex showing the summit cone, summit caldera ice field, Kidazgeni Glacier, Crater Peak, and location of hydrothermal water sample collected on April 14, 2006

Figure 12. Photograph showing fumarolic plume trailing to the south from Mount Spurr as seen from Anchorage, September 10, 2006

Figure 13. Photograph showing aerial view of the flank of Augustine Volcano, January 12, 2006

Figure 14. Photograph showing eruption cloud from Augustine Volcano as seen from Kokhanok, Alaska, January 13, 2006

Figure 15. Photograph showing first sighting of new lava at the summit of Augustine Volcano, January 16, 2006

Figure 16. Photograph showing steam and gas plume containing minor ash extending northeastward from Augustine Volcano during the continuous eruption phase of activity, January 30, 2006

Figure 17A. Photograph showing view of the north flank of Augustine Volcano with a towering steam and gas plume rising from the 2006 lava dome at the summit, May 2006

Figure 17B. Photograph showing steaming blocks of dome rock on the surface of the Rocky Point pyroclastic flow fan on the north flank of Augustine Volcano, February 8, 2006.

Figure 18. Forward Looking Infrared Radiometer (FLIR) and visual images of Augustine Volcano's north flank showing the active lava-flow lobes and summit lava dome

Figure 19. Photograph showing spalling of hot rock from the front of the unstable northern lava flow created this block and ash avalanche and elutriate cloud as photographed from offshore about 8:00 a.m. ADT, May 26, 2006 


\section{Figures-Continued}

Figure 20. Photograph showing oblique aerial view, towards the southwest, of the summit region of Augustine Volcano, August 7, 2006

Figure 21. Photograph showing aerial view of the 2006 lava dome and upper reaches of the lava-flow lobes showing the diversity of surface textures related to extrusion

Figure 22. Preliminary geologic map of products from the 2005-06 eruption of Augustine Volcano and location of primary geophysical and visual monitoring instrumentation sites....

Figure 23. Photograph showing eruptive plume rising above Fourpeaked volcano on September 17, 2006

Figure 24. Map showing Cook Inlet showing the location of Fourpeaked volcano $\ldots \ldots \ldots \ldots . . .40$

Figure 25. Map showing radar data for the September 17 plume from Fourpeaked volcano

Figure 26. Map showing sulfur-dioxide cloud detected on September 17, 2006, by the OMl sensor

Figure 27. Photograph showing dark, muddy debris flow that exited cracks in glacial ice about $4 \mathrm{~km}$ (2.5 mi) north of Fourpeaked summit on September 17, 2006

Figure 28. Photograph showing aerial view of vents through glacial ice and the source of the September 17, 2006, eruption at Fourpeaked volcano

Figure 29. Photograph showing aerial view of vents and pits through glacial ice and the source of the September 17, 2006, eruption at Fourpeaked volcano

Figure 30. Photograph showing view into the bottom of one of the non-venting pits at Fourpeaked volcano

Figure 31. Photograph showing aerial view of debris outflow chasm below the eruption site at Fourpeaked volcano

Figure 32. Close-up photograph of the cavernous point of origin of the September 17, 2006, outflow event at an elevation of about 5,000 $\mathrm{ft}(1500 \mathrm{~m})$ on the glacier draining the northwest flank of Fourpeaked volcano

Figure 33. Photograph showing view looking upslope into the deeply incised canyon produced during the outflow event

Figure 34. Photograph showing block of glacial ice in levee produced by the outburst flood from Fourpeaked volcano, September 17, 2006

Figure 35. Preliminary map of selected features and deposits related to the September 17, 2006, eruption of Fourpeaked volcano

Figure 36. Photograph showing Alaska Volcano Observatory geologist samples very fine dusting of ash from the September 17, 2006, phreatic eruption of Fourpeaked volcano

Figure 37. Photograph showing summit crater, shallow lake, fumaroles, and plume at Mount Martin, one of the Katmai group volcanoes

Figure 38. Plots of seismicity reflecting the seismic swarm at Mount Martin, January 2006 ... 54

Figure 39. Alaska Volcano Observatory web camera image from Perryville showing a low-level ash and gas emission from the intracaldera cone of Veniaminof Volcano, March 23, 2006

Figure 40. Photograph showing aerial view of the summit caldera of Veniaminof Volcano, June 5, 2006

Figure 41. Photograph showing eruption cloud from Cleveland volcano as seen from the International Space Station, May 23, 2006. 


\section{Figures-Continued}

Figure 42. Video frame grab of an eruption in progress at Cleveland volcano,

August 24, 2006

Figure 43. Collection of daytime thermal images of Cleveland taken by the Advanced Spaceborne Thermal Emission and Reflection Radiometer (ASTER) sensor at 22:35 UTC on November 4, 2006

Figure 44. Photograph showing a vapor plume rises above the Korovin volcano summit crater, October 29, 2006 .

Figure 45. ASTER satellite image of a portion of Atka Island showing a fresh ash (?) deposit on the upper flank and crater rim of Korovin, November 18, 2006.........63

Figure 46. Photograph showing aerial view into the summit crater of Korovin ............. 64

Figure 47. Photograph showing view of the east flank of Korovin volcano, July 7, $2004 \ldots . .65$

Figure 48. InSAR interferogram for the northern part of Atka Island showing the circular pattern of uplift that occurred during July through October 2006

Figure 49. Photograph showing a puff of vapor rises above the Korovin summit crater,

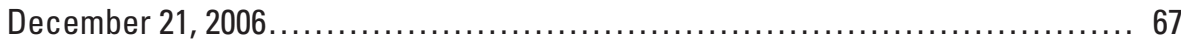

Figure 50. Telephoto image showing a robust, continuous plume of water vapor rises from Korovin volcano, December 24, 2006.

Figure 51. Map and photographs of thermal areas on north Atka Island based on fieldwork in 2004

Figure 52. Photograph showing view of the lake at Kasatochi from the south rim of the caldera, May 26, 2006

Figure 53. Telephoto view of the lake at Kasatochi from the south rim of the caldera, June 2, 2006

Figure 54. QuickBird satellite image of Kasatochi volcano taken at 22:45:59 UTC on April 9, 2004

Figure 55. Photograph showing view towards the southeast from the rim of the lake-filled summit crater of Kasatochi volcano, August 3, 2004.

Figure 56. Map of Kamchatka Peninsula and the northern Kurile Islands of Alaid and Paramushir ....

Figure 57. Photograph showing Sheveluch Volcano in eruption viewed to the north from Klyuchi, December 17, 2006

Figure 58. MODIS image of ash cloud from Sheveluch Volcano on December 27, 2006, at 0135 UTC

Figure 59. Photograph showing aerial view of Klyuchevskoy Volcano during a helicopter overflight, August 11, 2006

Figure 60. Photograph showing aerial view of the summit crater and active dome of Bezymianny Volcano, April 1, 2006

Figure 61. Photograph showing Bezymianny eruption cloud, May 9, 2006. 80

Figure 62. Photograph of new seismic station being installed as part of a network for monitoring Bezymianny Volcano

Figure 63. Map showing seismic stations (white triangles) in the vicinity of the Klyuchevskoy group of volcanoes and Sheveluch (northernmost volcano), 2006 ... 82

Figure 64. Photograph showing Bezymianny Volcano from the south, December 27, $2006 \quad \ldots 83$

Figure 65. Photograph showing Karymsky Volcano in eruption as seen through the haze from the cockpit of a jet flying at 9,100 m altitude $(29,800 \mathrm{ft}) \mathrm{ASL}$, June $28,2006 \quad \ldots 84$ 


\section{Figures-Continued}

Figure 66. MODIS image of Karymsky Volcano eruption cloud, November 7, $2006 \quad \ldots \ldots \ldots . . .85$

Figure 67. Plot showing number of shallow earthquakes per day at Karymsky

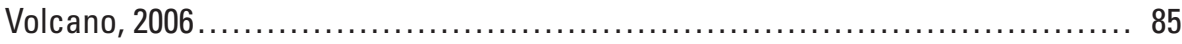

Figure 68. Map of Kurile Islands with place names used in this report $\ldots \ldots \ldots \ldots \ldots \ldots \ldots \ldots \ldots$

Figure 69. Satellite image composites of possible activity from Severgin Volcano .......... 88

Figure 70. Photograph showing Berga Volcano showing central lava dome with active fumarolic emission within the 2-km (1.2-mi) diameter Berg caldera, 1996 ......... 89

Figure 71. Photograph showing strong water vapor and volcanic-gas emission at Berga Volcano, 2005

\section{Tables}

Table 1. History of seismic monitoring of Alaskan volcanoes from August 1971 through December 2006

Table 2. Summary of 2006 VOLCANIC ACTIVITY in Alaska, including actual eruptions, possible eruptions, unusual increases in seismicity or fumarolic activity .......... 5

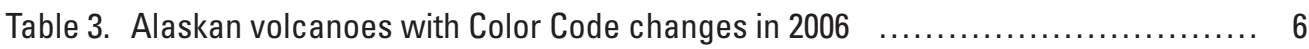

Table 4a. Compilation by year of volcanoes included in an Alaska Volcano Observatory Annual Summary, 1992-2006

Table 4b. Compilation by volcano for particular years included in an Alaska Volcano Observatory Annual Summary, 1992-2006

Table 5. Chronology of events and observations relating to volcanic unrest at Mount Spurr, Alaska, 2004-06

Table 6. Chemical analyses of water sampled at the Crater Creek warm springs and the Kidazgeni Glacier outlet stream

Table 7. Preliminary chronology of major events and selected formal Alaska Volcano Observatory notifications pertaining to the 2005-06 unrest and eruption of Augustine Volcano, Alaska

Table 8. 2006 activity at Cleveland volcano, compiled from Alaska Volcano Observatory information-release statements, internal-log entries, and summaries

Table 9. Seismically monitored volcanoes of Kamchatka as of December 2006.

Table 10. Summary of VOLCANIC ACTIVITY on Kamchatka Peninsula and in the Kurile Islands, Russia, 2006 75

Table 11. Kamchatkan volcanoes with Color Code changes in 2006 


\section{Conversion Factors and Datum}

Inch/Pound to SI

\begin{tabular}{lcl}
\hline Multiply & By & To obtain \\
\hline acre & 4,047 & square meter $\left(\mathrm{m}^{2}\right)$ \\
cubic mile $\left(\mathrm{mi}^{3}\right)$ & 4.168 & cubic kilometer $\left(\mathrm{km}^{3}\right)$ \\
foot $(\mathrm{ft})$ & 0.3048 & meter $(\mathrm{m})$ \\
foot $(\mathrm{ft})$ & 0.000305 & kilometer $(\mathrm{km})$ \\
inch (in.) & 25.4 & millimeter $(\mathrm{mm})$ \\
inch (in.) & 2.54 & centimeter $(\mathrm{cm})$ \\
mile (mi) & 1.609 & kilometer $(\mathrm{km})$ \\
ton per day (ton/d) & 0.9072 & metric ton per day \\
\hline
\end{tabular}

Temperature in degrees Fahrenheit $\left({ }^{\circ} \mathrm{F}\right)$ may be converted to degrees Celsius $\left({ }^{\circ} \mathrm{C}\right)$ as follows:

${ }^{\circ} \mathrm{C}=\left({ }^{\circ} \mathrm{F}-32\right) / 1.8$.

SI to Inch/Pound

\begin{tabular}{lcl}
\hline Multiply & \multicolumn{1}{c}{ By } & To obtain \\
\hline cubic kilometer $\left(\mathrm{km}^{3}\right)$ & 0.2399 & cubic mile $\left(\mathrm{mi}^{3}\right)$ \\
kilometer $(\mathrm{km})$ & 0.6214 & mile $(\mathrm{mi})$ \\
kilometer $(\mathrm{km})$ & 3,281 & foot $(\mathrm{ft})$ \\
meter $(\mathrm{m})$ & 3.281 & foot $(\mathrm{ft})$ \\
centimeter $(\mathrm{cm})$ & 0.3937 & inch (in.) \\
metric ton per day & 1.1022 & ton per day (ton/d) \\
millimeter $(\mathrm{mm})$ & 0.03937 & inch (in.) \\
square meter $\left(\mathrm{m}^{2}\right)$ & 0.0002471 & acre \\
\hline
\end{tabular}

Temperature in degrees Celsius $\left({ }^{\circ} \mathrm{C}\right)$ may be converted to degrees Fahrenheit $\left({ }^{\circ} \mathrm{F}\right)$ as follows:

$$
{ }^{\circ} \mathrm{F}=\left(1.8 x^{\circ} \mathrm{C}\right)+32 \text {. }
$$

Datum

Altitude and elevation as used in this report, refers to distance above sea level, unless otherwise noted. 


\title{
2006 Volcanic Activity in Alaska, Kamchatka, and the Kurile Islands: Summary of Events and Response of the Alaska Volcano Observatory
}

\author{
By Christina A. Neal', Robert G. McGimsey', James P. Dixon², Alexander Manevich ${ }^{3}$, and Alexander Rybin ${ }^{4}$
}

\section{Abstract}

The Alaska Volcano Observatory (AVO) responded to eruptions, possible eruptions, and volcanic unrest at or near nine separate volcanic centers in Alaska during 2006. A significant explosive eruption at Augustine Volcano in Cook Inlet marked the first eruption within several hundred kilometers of principal population centers in Alaska since 1992. Glaciated Fourpeaked Mountain, a volcano thought to have been inactive in the Holocene, produced a phreatic eruption in the fall of 2006 and continued to emit copious amounts of volcanic gas into 2007. AVO staff also participated in hazard communication and monitoring of multiple eruptions at seven volcanoes in Russia as part of its collaborative role in the Kamchatka and Sakhalin Volcanic Eruption Response Teams.

\section{Introduction}

The Alaska Volcano Observatory (AVO) monitors, reports, and studies volcanic unrest at Alaskan volcanoes. The year 2006 was dominated by 3 months of eruptive activity at Augustine Volcano in Cook Inlet, and a surprising phreatic eruption at the ice-clad Fourpeaked volcano on the northern Alaska Peninsula. AVO also responded to new and ongoing volcanic unrest at several other volcanoes in Alaska (fig. 1).

As of December 31, 2006, 30 of the more than 40 historically active volcanoes are instrumented with a network of seismometers sufficiently reliable in their

${ }^{1}$ U.S. Geological Survey, Alaska Volcano Observatory, Alaska Science Center, 4210 University Dr., Anchorage, Alaska 99508-4664.

${ }^{2}$ U.S. Geological Survey Alaska Volcano Observatory, Alaska Science Center, 903 Koyukuk Drive, Fairbanks, Alaska 99775-7320.

${ }^{3}$ Kamchatka Volcanic Eruptions Response Team, Institute of Volcanology and Seismology, Piip Blvd., 9 Petropavlovsk-Kamchatsky, Russia 683006.

${ }^{4}$ Sakhalin Volcanic Eruptions Response Team, Institute of Marine Geology and Geophysics, Nauki Street Yuzhno-Sakhalinsk, Russia 693022. operation to consistently track earthquake activity (fig. 1;

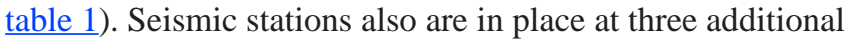
volcanoes (Little Sitkin, Semisopochnoi, Fourpeaked (fig. 1); however, telemetry links are intermittent and background seismicity has not been confidently determined. Thus, AVO does not yet consider these volcanoes formally monitored with seismic instrumentation. AVO's volcano monitoring program also includes daily analysis of satellite imagery, web cameras, occasional overflight observations and airbornegas measurements, and compilation of pilot reports and observations of local residents and mariners. In addition, AVO receives real-time deformation information from permanent Global Positioning System (GPS) stations at four Alaskan volcanoes (Okmok, Augustine, Akutan, and Mount Spurr). In recent years, periodic analysis of Interferometric Synthetic Aperture Radar (InSAR) imagery also has been used to detect deformation at volcanoes in Alaska (Lu and others, 2003; Lu, 2007; Lu and others, (2007).

AVO also participates in satellite monitoring of Russian volcanoes and assists in disseminating hazard information on behalf of the Kamchatkan Volcanic Eruption Response Team (KVERT; Kirianov and others, 2002) and the Sakhalin Volcanic Eruption Response Team (SVERT; Rybin and others, 2004). In 2006, AVO assisted in broadcasting alerts about eruptive activity at four Russian volcanoes in Kamchatka (Sheveluch, Klyuchevskoy, Bezymianny, and Karymsky). Ebeko, a volcano on Paramushir Island in the North Kuriles, experienced a period of increased fumarolic output. No other volcanoes in the Kuriles exhibited significant unrest in 2006, although Russian satellite monitoring detected clouds of possible volcanic origin from two small island volcanoes, Severgin and Berga. SVERT issued no formal warnings in 2006. 


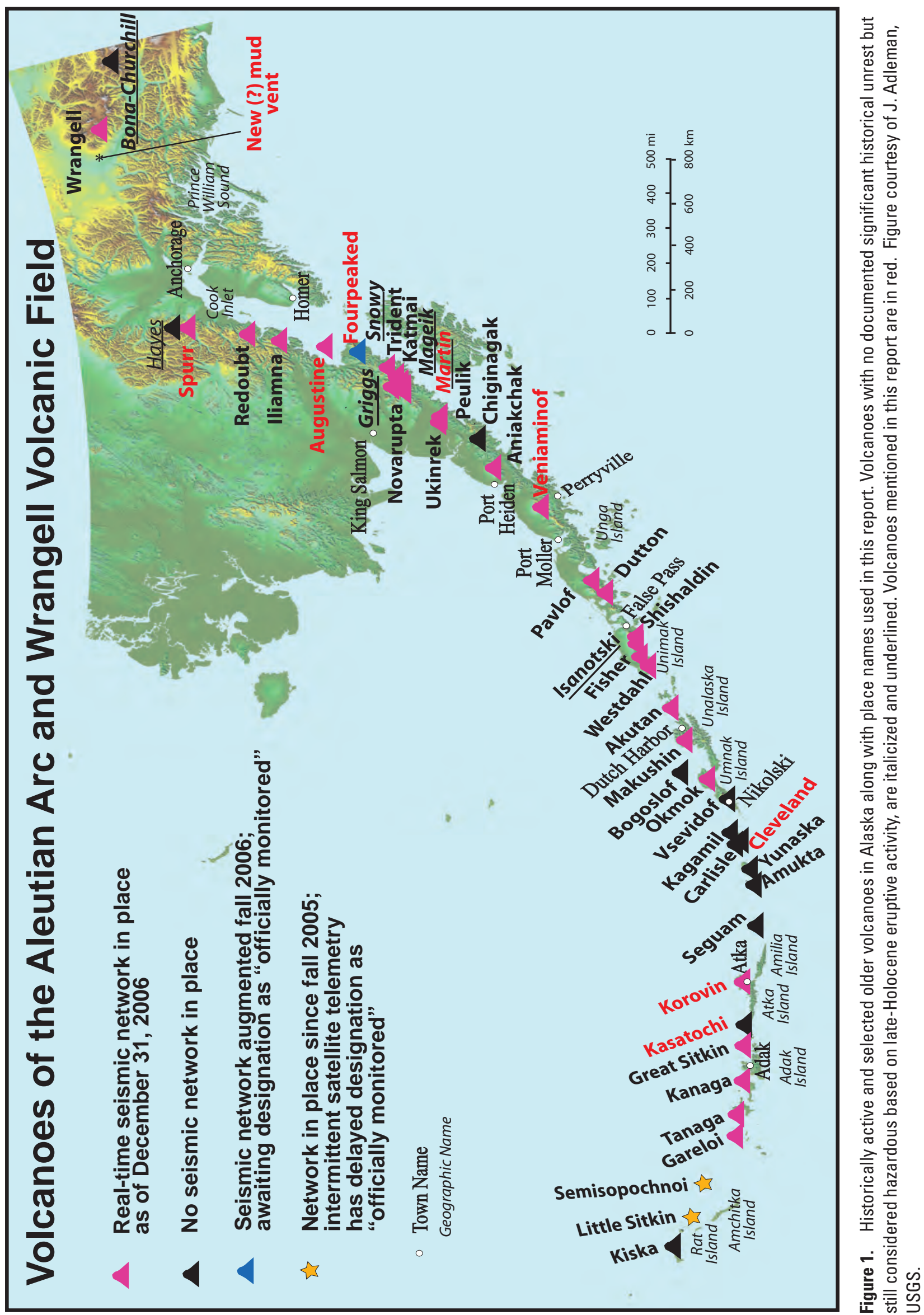


Table 1. History of seismic monitoring of Alaskan volcanoes from August 1971 through December 2006.

[History of seismic monitoring compiled by J. Dixon, U.S. Geological Survey (2006). "First station installed" is defined as the receipt of real-time data from the station. This date can be many months following initial fieldwork at the volcano. Alaska Volcano Observatory (AVO) considers the seismic network "complete" following installation and data transmission from a minimum of four seismic stations. Typically, AVO seismologists wait about six months or more to understand background rates of seismicity before formally declaring a volcano seismically monitored and adding it to the monitored list. We note here the first mention of the seismic status of each monitored volcano in the AVO weekly update. Regularly issued written information statements began during the Redoubt eruption in 1989-90 and were expanded to include all Cook Inlet volcanoes in April 1991. The Magnitude of Completeness is the lowest magnitude that can confidently be located for activity detected in 2006]

\begin{tabular}{|c|c|c|}
\hline Volcano & Approximate start date of seismic monitoring & $\begin{array}{l}\text { Magnitude of } \\
\text { completeness }\end{array}$ \\
\hline Wrangell & $\begin{array}{l}\text { First station installed - July } 2000 \\
\text { Network complete - August } \mathbf{2 0 0 1} \\
\text { Added to monitored list in weekly update - November } 2001\end{array}$ & 0.9 \\
\hline Spurr & $\begin{array}{l}\text { First station installed - August } 1971 \\
\text { Network complete - August } \mathbf{1 9 8 9} \\
\text { Added to monitored list in weekly update - April } 1991\end{array}$ & 0.2 \\
\hline Redoubt & $\begin{array}{l}\text { First station installed - August } 1971 \\
\text { Network complete - August } \mathbf{1 9 8 8} \\
\text { Added to monitored list in weekly update - April } 1991\end{array}$ & 0.1 \\
\hline Iliamna & $\begin{array}{l}\text { First station installed - September } 1987 \\
\text { Network complete (Min } 4 \text { stations) - September } 1994 \\
\text { Added to monitored list in weekly update - April } 1991\end{array}$ & -0.4 \\
\hline Augustine & $\begin{array}{l}\text { First station installed - October } 1976 \\
\text { Network complete - August } \mathbf{1 9 7 8} \\
\text { Added to monitored list in weekly update - April } 1991\end{array}$ & 0.0 \\
\hline Fourpeaked & $\begin{array}{l}\text { First station installed - September } 2006 \\
\text { Network complete (Min } 4 \text { stations) - October } \mathbf{2 0 0 6} \\
\text { Added to monitored list in weekly update - not yet added }\end{array}$ & 0.7 \\
\hline Katmai-North (Snowy) & $\begin{array}{l}\text { First station installed - August } 1988 \\
\text { Network complete - October } 1998 \\
\text { Added to monitored list in weekly update - December } 1998\end{array}$ & 0.5 \\
\hline $\begin{array}{l}\text { Katmai-Central (Griggs, } \\
\text { Katmai, Novarupta, } \\
\text { Trident) }\end{array}$ & $\begin{array}{l}\text { First station installed - August } 1988 \\
\text { Network complete (Min } 4 \text { stations) - July } 1991 \\
\text { Added to monitored list in weekly update - November } 1996\end{array}$ & 0.5 \\
\hline $\begin{array}{l}\text { Katmai-South } \\
\quad \text { (Martin, Mageik) }\end{array}$ & $\begin{array}{l}\text { First station installed - August } 1988 \\
\text { Network complete - July } 1996 \\
\text { Added to monitored list in weekly update - November } 1996\end{array}$ & 0.2 \\
\hline Ukinrek Maars/ Peulik & $\begin{array}{l}\text { First station installed - March } 2005 \\
\text { Network complete (Min } 4 \text { stations) - March } 2005 \\
\text { Added to monitored list in weekly update - April } 2005\end{array}$ & 0.9 \\
\hline Aniakchak & $\begin{array}{l}\text { First station installed - July } 1997 \\
\text { Network complete - July } 1997 \\
\text { Added to monitored list in weekly update - November } 1997\end{array}$ & 1.7 \\
\hline Veniaminof & $\begin{array}{l}\text { First station installed - February } 2002 \\
\text { Network complete - February } \mathbf{2 0 0 2} \\
\text { Added to monitored list in weekly update - September } 2002\end{array}$ & 1.5 \\
\hline Pavlof & $\begin{array}{l}\text { First station installed - July } 1996 \\
\text { Network complete - July } \mathbf{1 9 9 6} \\
\text { Added to monitored list (in weekly update - November } 1996\end{array}$ & 0.7 \\
\hline
\end{tabular}


Table 1. History of seismic monitoring of Alaskan volcanoes from August 1971 through December 2006.-Continued

[History of seismic monitoring compiled by J. Dixon, U.S. Geological Survey (2006). "First station installed" is defined as the receipt of real-time data from the station. This date can be many months following initial fieldwork at the volcano. Alaska Volcano Observatory (AVO) considers the seismic network "complete" following installation and data transmission from a minimum of four seismic stations. Typically, AVO seismologists wait about six months or more to understand background rates of seismicity before formally declaring a volcano seismically monitored and adding it to the monitored list. We note here the first mention of the seismic status of each monitored volcano in the AVO weekly update. Regularly issued written information statements began during the Redoubt eruption in 1989-90 and were expanded to include all Cook Inlet volcanoes in April 1991. The Magnitude of Completeness is the lowest magnitude that can confidently be located for activity detected in 2006]

\begin{tabular}{|c|c|c|}
\hline Volcano & Approximate start date of seismic monitoring & $\begin{array}{l}\text { Magnitude of } \\
\text { completeness }\end{array}$ \\
\hline Dutton & $\begin{array}{l}\text { First station installed - July } 1988 \\
\text { Network complete - July } \mathbf{1 9 9 6} \\
\text { Added to monitored list in weekly update - November } 1996\end{array}$ & 0.9 \\
\hline Shishaldin (and Isantoski) & $\begin{array}{l}\text { First station installed - July } 1997 \\
\text { Network complete - July } \mathbf{1 9 9 7} \\
\text { Shishaldin added to list in weekly update - November } 1997 \\
\text { Isantoski added to list in weekly update - December } 1998\end{array}$ & 0.5 \\
\hline Westdahl (and Fisher) & $\begin{array}{l}\text { First station installed - August } 1998 \\
\text { Network complete - October } 1998 \\
\text { Added to monitored list in weekly update - December } 1998\end{array}$ & 0.6 \\
\hline Akutan & $\begin{array}{l}\text { First station installed - March } 1996 \\
\text { Network complete - July } 1996 \\
\text { Added to monitored list in weekly update - November } 1996\end{array}$ & 0.4 \\
\hline Makushin & $\begin{array}{l}\text { First station installed - July } 1996 \\
\text { Network complete - July } 1996 \\
\text { Added to monitored list in weekly update - November } 1996\end{array}$ & 1.0 \\
\hline Okmok & $\begin{array}{l}\text { First station installed - January } 2003 \\
\text { Network complete - January } \mathbf{2 0 0 3} \\
\text { Added to monitored list in weekly update - January } 2004\end{array}$ & 0.9 \\
\hline Korovin & $\begin{array}{l}\text { First station installed - July } 2004 \\
\text { Network complete - July } 2004 \\
\text { Added to monitored list in weekly update - December } 2005\end{array}$ & 0.8 \\
\hline Great Sitkin & $\begin{array}{l}\text { First station installed - September } 1999 \\
\text { Network complete - September } 1999 \\
\text { Added to monitored list in weekly update - December } 1999\end{array}$ & 0.6 \\
\hline Kanaga & $\begin{array}{l}\text { First station installed - September } 1999 \\
\text { Network complete - September } 1999 \\
\text { Added to monitored list in weekly update - December } 2000\end{array}$ & 1.2 \\
\hline Tanaga & $\begin{array}{l}\text { First station installed - August } 2003 \\
\text { Network complete - August } \mathbf{2 0 0 3} \\
\text { Added to monitored list in weekly update - June } 2004\end{array}$ & 1.1 \\
\hline Gareloi & $\begin{array}{l}\text { First station installed - August } 2003 \\
\text { Network complete - September } \mathbf{2 0 0 3} \\
\text { Added to monitored list in weekly update - June } 2004\end{array}$ & 1.0 \\
\hline Semisopochnoi (Cerberus) & $\begin{array}{l}\text { First station installed - September } 2005 \\
\text { Network complete - September } \mathbf{2 0 0 5} \\
\text { Added to monitored list in weekly update - not yet added }\end{array}$ & 1.2 \\
\hline Little Sitkin & $\begin{array}{l}\text { First station installed - September } 2005 \\
\text { Network complete - September } \mathbf{2 0 0 5} \\
\text { Added to monitored list in weekly update - not yet added }\end{array}$ & 0.6 \\
\hline
\end{tabular}




\section{New volcano hazard alert system announced in 2006}

The USGS Volcano Hazards Program adopted a unified hazard warning system in late 2006 (Gardner and Guffanti, 2006). The long-used, level of concern color code system became an aviation-only message. A parallel system of volcano alert levels communicates the overall hazard level at a volcano using terms more consistent with National Weather Service messages: NORMAL, ADVISORY, WATCH, WARNING. AVO began to use this code in late September. Appendixes 1 and 2 explain the previous level of concern code system and the new system. Also note that KVERT continued to use the old color code system through 2006 and into 2007 (appendix 1).

This report summarizes volcanic activity in Alaska, Kamchatka, and the Kuriles in 2006 and briefly describes AVO's operational response. Descriptions are presented in geographic order from northeast to southwest along the Aleutian Arc, and north to south in Kamchatka and the Kuriles. Each event summary ends with a paragraph providing background comments on the volcano in question. Information is derived primarily from AVO daily status reports, weekly updates and special information releases, internal bimonthly reports, AVO email and online electronic logs, and the Smithsonian Institution Global Volcanism Network Bulletins that are available at URL: http://www.volcano.si.edu/reports/ bulletin/index.cfm. Table 1 is a history of seismic monitoring of Alaskan volcanoes from August 1971 through December 2006. Table 2 summarizes 2006 volcanic activity in Alaska. Table 3 summarizes changes in color codes in 2006 for Alaskan volcanoes. Table 4 presents cross-referenced lists of volcanic activity by year and by volcano for all previous reports (1992-2006).
Only activity that resulted in a significant investment of staff time (defined here as several hours or more for reaction, tracking, and follow-up) is included. Where more extensive published documentation for an episode of unrest exists, we provide key references. Over the course of the year, AVO typically receives dozens of reports of steaming, unusual cloud sightings, or false eruption reports. Most of these are resolved very quickly and are not tabulated here as part of the response record. On rare occasions, AVO issues an information release to dispel rumors of volcanic activity. In years past, we have used the phrase "suspect volcanic activity" (SVA) to characterize unusual activity that is subsequently determined to be normal or merely enhanced fumarolic activity, weatherrelated phenomena, or other non-volcanic events. Beginning with this year's compilation, we have ceased using this term as it has presented us with problems of consistency.

Table 2. Summary of 2006 VOLCANIC ACTIVITY in Alaska, including actual eruptions, possible eruptions, unusual increases in seismicity or fumarolic activity.

[Location of volcanoes shown in figure 1]

\begin{tabular}{|c|c|c|}
\hline Volcano & Date of activity & Type of activity \\
\hline Mount Spurr & Ongoing & $\begin{array}{l}\text { Waxing and waning of ice-cover on summit geothermal lake. No further } \\
\text { increases in seismicity or gas output. }\end{array}$ \\
\hline Augustine & January 11 - end of March & Explosions and lava effusion January-March. \\
\hline Fourpeaked & September 17 - end of year & Phreatic eruption in September, continued vigorous magmatic degassing. \\
\hline Veniaminof & Intermittently throughout the year & $\begin{array}{l}\text { Minor steam and ash plumes; persistent seismicity indicative of phreatic (?) } \\
\text { activity from the intracaldera cinder and spatter cone. }\end{array}$ \\
\hline Cleveland & Intermittently throughout the year & Explosions and small ash clouds. \\
\hline Korovin & Intermittently throughout the year & $\begin{array}{l}\text { Periods of tremor, volcano-tectonic seismicity, increased fumarolic output, } \\
\text { and disappearance of the summit lake at Korovin. }\end{array}$ \\
\hline
\end{tabular}


Table 3. Alaskan volcanoes with Color Code changes in 2006.

[Description of Level of Concern Color Codes is shown in appendix 1. Local times (AST) are only shown where color code changes were short-lived during rapidly evolving events. NA (not assigned): Volcanoes that do not have a realtime seismic network are not assigned a color code GREEN because without seismic data, Alaska Volcano Observatory has no definitive information that the level of activity at the volcano is at background]

\begin{tabular}{|c|c|}
\hline Color Code & Date of change \\
\hline \multicolumn{2}{|r|}{ MOUNT SPURR } \\
\hline YELLOW & January $1-F e b r u a r y ~ 21$ \\
\hline GREEN & February 21-December 31 \\
\hline \multicolumn{2}{|r|}{ AUGUSTINE } \\
\hline YELLOW & January $1-102110$ \\
\hline ORANGE & January 10 2110- January 110550 \\
\hline RED & January $110550-$ January 120825 \\
\hline ORANGE & January $120825-$ January 130400 \\
\hline RED & January 13 0400-January 150945 \\
\hline ORANGE & January 15 0945-January 170800 \\
\hline RED & January 17 0800-January 180950 \\
\hline ORANGE & January 18 0950-January 272035 \\
\hline RED & January 27 2035-February 10945 \\
\hline ORANGE & February $10945-$ April 280945 \\
\hline YELLOW & April 280945 -August 91500 \\
\hline GREEN & August 9-December 31 \\
\hline \multicolumn{2}{|r|}{ FOURPEAKED } \\
\hline Not Assigned & January $1-$ September 20 \\
\hline YELLOW & September 20-December 31 \\
\hline \multicolumn{2}{|r|}{ MARTIN } \\
\hline GREEN & January 1-January 10 \\
\hline YELLOW & January $10-$ January 27 \\
\hline GREEN & January 27-December 31 \\
\hline \multicolumn{2}{|r|}{ VENIAMINOF } \\
\hline GREEN & January 1-March 3 \\
\hline YELLOW & March 3-December 31 \\
\hline \multicolumn{2}{|r|}{ CLEVELAND } \\
\hline Not Assigned & January 1-February 6 \\
\hline RED & February $61025-1655$ \\
\hline ORANGE & February 6 1655-February 111355 \\
\hline YELLOW & February 11 1355-February 201355 \\
\hline Not Assigned & February 20 1355-May 23 \\
\hline YELLOW & May 23-May 26 \\
\hline Not Assigned & May 26-September 7 \\
\hline YELLOW & September 7-October 28 \\
\hline ORANGE & October $28-$ October 30 \\
\hline YELLOW & October 30-December 31 \\
\hline \multicolumn{2}{|r|}{ KOROVIN } \\
\hline GREEN & January 1-February 22 \\
\hline YELLOW & February 22-March 8 \\
\hline GREEN & March 8-November 6 \\
\hline YELLOW & November 6-December 31 \\
\hline
\end{tabular}

\section{Increasing monitoring, increasing information, more to report}

As AVO has expanded instrumental monitoring and made use of the increasing number of high resolution satellite platforms, the threshold of detection of volcanic unrest in Alaska has lowered considerably. In addition, increasing air and marine-vessel traffic in the Aleutians along with improved Internet and other telecommunications infrastructure in remote Alaska, and the highly visible web presence of AVO may contribute to the increased the number of reports of volcanic activity we receive, evaluate, and log. The focus of this report is on volcanic activity that represents a significant departure from 'background', a somewhat loosely defined state of quiet at a given volcano. For a more quantitative picture of the level of volcanic unrest, readers are referred to the catalog of seismicity at Alaskan volcanoes, also produced on an annual basis (for example, Dixon and others, 2006).

Altitudes and elevations reported are in feet and/or meters above sea level (ASL) unless noted, and time is reported as Alaska Standard Time (AST), Alaska Daylight Time (ADT), Kamchatkan Standard Time (KST), or Kamchatkan Daylight Time (KDT) as needed, with Coordinated Universal Time (UTC) in parentheses. For most satellite or geophysical instrumentation references, times are given in UTC. We preserve English or Inch-Pound units of measurement especially where they reflect the primary observations of distance or altitude such as those commonly received via pilot reports and aviation authorities in the United States. Elsewhere, measurements are presented in International System of Units (SI) with Inch-Pound Units in parentheses for convenience. Volcano locations in latitude and longitude and summit elevations are taken from the Alaska Volcano Observatory database and may differ slightly from previously published compilations. 
Table 4a. Compilation by year of volcanoes included in an Alaska Volcano Observatory Annual Summary, 1992-2006.

[Volcanoes are presented in geographical order from northeast to southwest along the Wrangell-Aleutian volcanic arc and north to south along Kamchatka and the Kurile Islands. Prior to 1995, Alaska Volcano Observatory did not report on Russian volcanoes]

\begin{tabular}{ccc}
\hline \multicolumn{2}{c}{ Volcanoes mentioned } \\
\hline Alaskan & Russian \\
\hline & 1992 & \\
\hline
\end{tabular}

Spurr/Crater Peak

Iliamna

Redoubt

Mageik (Katmai Group)

Westdahl

Akutan

Bogoslof

Seguam

1993

\begin{tabular}{l}
\hline Churchill \\
Sanford \\
Spurr/Crater Peak \\
Veniaminof \\
Shishaldin \\
Makushin \\
Seguam \\
Kliuchef (Atka) \\
Kanaga \\
\hline
\end{tabular}

Sanford

Iliamna

Katmai Group (Martin,

Mageik, Trident)

Veniaminof

Kupreanof

Shishaldin

Makushin

Cleveland

Kanaga

1995

\begin{tabular}{lc}
\hline & 1995 \\
\hline $\begin{array}{l}\text { Katmai Group (Martin) } \\
\text { Veniaminof }\end{array}$ & $\begin{array}{l}\text { Bezymianny } \\
\text { Khishaldin } \\
\text { Makushin } \\
\text { Kliuchef (Atka) } \\
\text { Kanaga }\end{array}$ \\
\hline & \\
\hline $\begin{array}{l}\text { Wrangell } \\
\text { Iliamna }\end{array}$ & \\
Katmai Group (Martin, \\
$\quad$ Mageik, Trident, Mount \\
$\quad$ Katmai) & Klyuchevskoy \\
Pavlof & Kezymianny \\
Shishaldin & Avachinsky \\
Westdahl & Mutnovsky \\
& Alaid (Kurile Islands)
\end{tabular}


Table 4a. Compilation by year of volcanoes included in an Alaska Volcano Observatory Annual Summary, 1992-2006.—Continued

[Volcanoes are presented in geographical order from northeast to southwest along the Wrangell-Aleutian volcanic arc and north to south along Kamchatka and the Kurile Islands. Prior to 1995, Alaska Volcano Observatory did not report on Russian volcanoes]

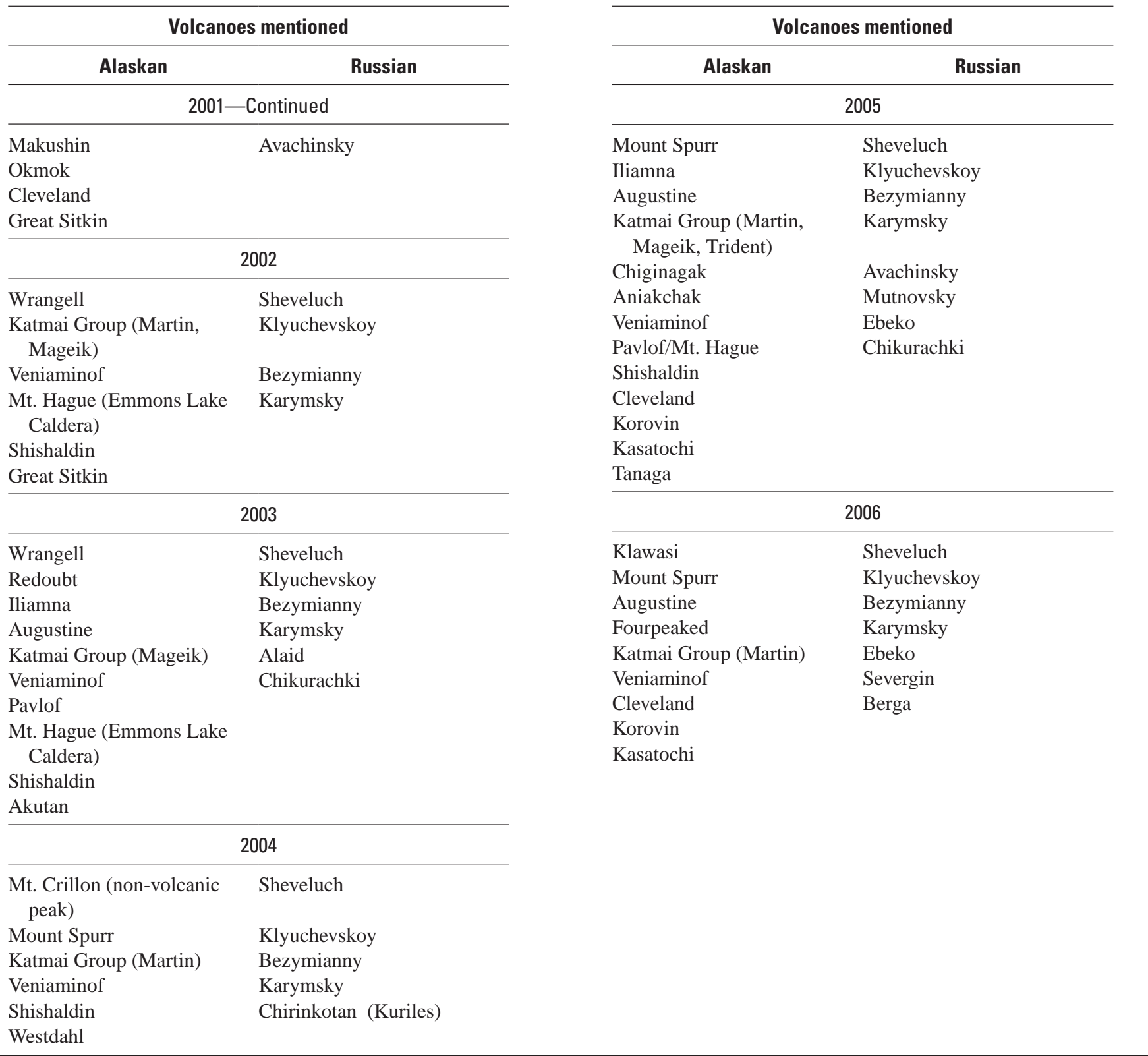


Table 4b. Compilation by volcano for particular years included in an Alaska Volcano Observatory Annual Summary, 1992-2006.

[Suspect Volcanic Activity (SVA) is defined as a report of eruption or possible eruption that is normal fumarolic activity or non-volcanic phenomena, such as weather related. PIREP, pilot weather report]

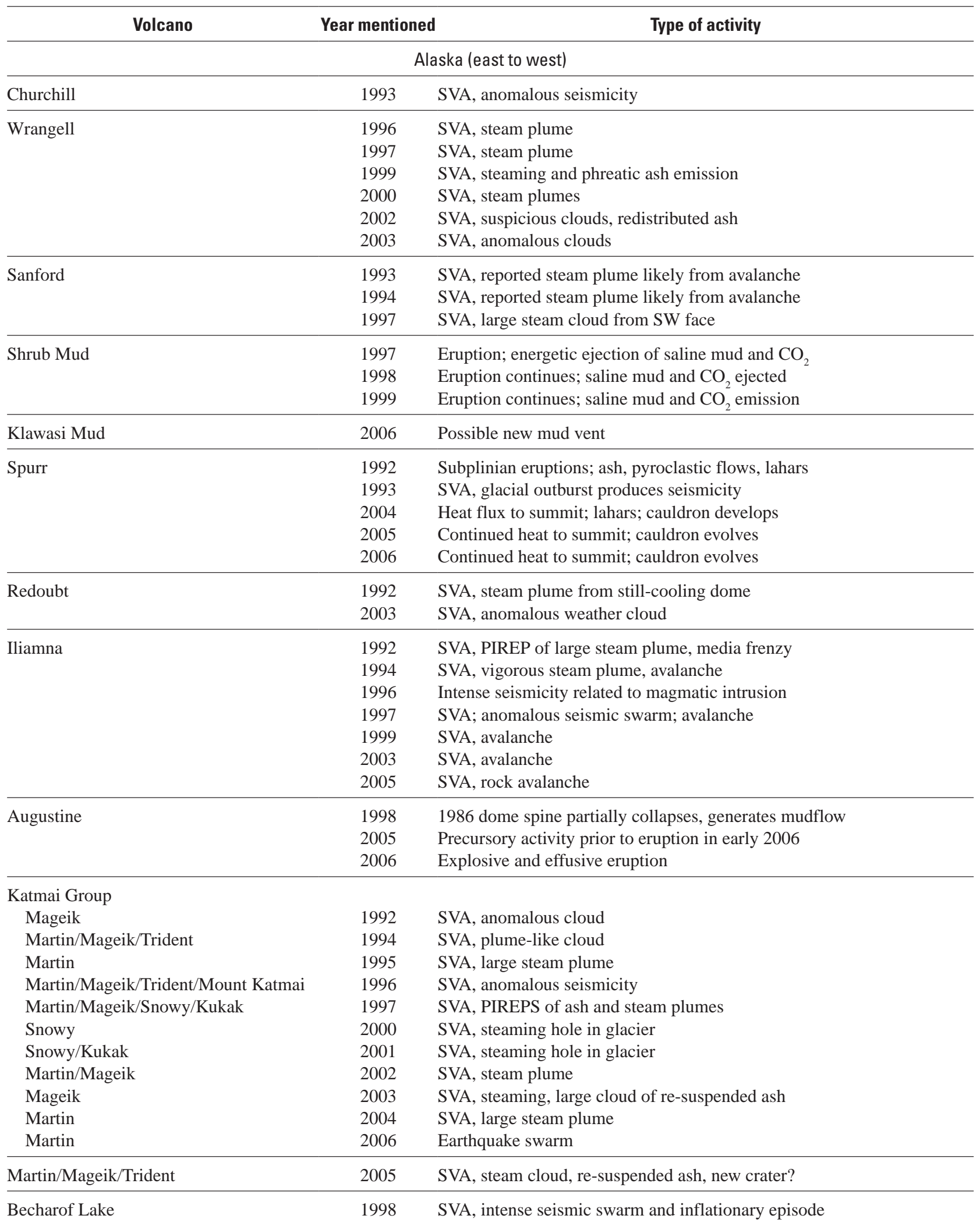


Table 4b. Compilation by volcano for particular years included in an Alaska Volcano Observatory Annual Summary, 1992-2006.-Continued

[Suspect Volcanic Activity (SVA) is defined as a report of eruption or possible eruption that is normal fumarolic activity or non-volcanic phenomena, such as weather related. PIREP, pilot weather report]

\begin{tabular}{|c|c|c|}
\hline Volcano & Year mentioned & Type of activity \\
\hline \multicolumn{3}{|c|}{ Alaska (east to west)—Continued } \\
\hline Chiginagak & $\begin{array}{l}1997 \\
1998 \\
2000 \\
2005\end{array}$ & $\begin{array}{l}\text { Minor eruptive activity, new fumarole field } \\
\text { SVA, continuation of increased fumarolic activity } \\
\text { SVA, steam emissions from fumarole field } \\
\text { Heat to summit; acidic flood; cauldron develops }\end{array}$ \\
\hline Aniakchak & 2005 & SVA, anomalous seismicity, thermal anomaly \\
\hline Veniaminof & $\begin{array}{l}1993 \\
1994 \\
1995 \\
1999 \\
2002 \\
2003 \\
2004 \\
2005 \\
2006\end{array}$ & $\begin{array}{l}\text { Low-level eruption and lava flows } \\
\text { Strombolian eruption and lava flows } \\
\text { Strombolian eruptions } \\
\text { SVA, extreme discharge and turbid river } \\
\text { Low-level phreatic eruptions } \\
\text { Low-level phreatic eruptions } \\
\text { Weak phreatic and Strombolian eruption } \\
\text { Intermittent phreatic and Strombolian eruption } \\
\text { Intermittent phreatic and Strombolian eruption }\end{array}$ \\
\hline Kupreanof & 1994 & SVA, PIREP of unusual steam plume \\
\hline Pavlof & $\begin{array}{l}1996 \\
1997 \\
1999 \\
2001 \\
2005\end{array}$ & $\begin{array}{l}\text { Strombolian eruption } \\
\text { Strombolian eruption concludes } \\
\text { SVA, summit snow melt, ash dustings, steam plumes } \\
\text { SVA, steaming, possible ash, sulfur smell } \\
\text { SVA, mis-located steam plume }\end{array}$ \\
\hline Hague (Emmons Lake Caldera) & $\begin{array}{l}2002 \\
2003 \\
2005\end{array}$ & $\begin{array}{l}\text { SVA, increase in fumarolic activity in summit crater } \\
\text { SVA, crater lake drains, refills, drains } \\
\text { SVA, steam plume }\end{array}$ \\
\hline Frosty & 2001 & SVA, rock fall avalanches \\
\hline Shishaldin & $\begin{array}{l}1993 \\
1994 \\
1995 \\
1996 \\
1997 \\
1998 \\
1999 \\
2000 \\
2001 \\
2002 \\
2003 \\
2004 \\
2005\end{array}$ & $\begin{array}{l}\text { Minor phreatic } \\
\text { SVA, PIREP of minor steam/ash } \\
\text { Minor eruptive activity, steam/ash } \\
\text { Eruption; steam/ash and thermal anomaly } \\
\text { Minor eruptive activity, steam/ash } \\
\text { Minor eruptive activity, steam/ash } \\
\text { Strombolian eruption } \\
\text { Minor eruptive activity, steam/ash } \\
\text { Minor unrest, seismicity increase, steam clouds } \\
\text { SVA, shallow seismicity; PIREP of possible eruption } \\
\text { SVA, steam plumes } \\
\text { Small steam and ash plumes } \\
\text { SVA, increased seismicity, steam plumes prompt PIREPS }\end{array}$ \\
\hline Westdahl & $\begin{array}{l}1992 \\
1996 \\
2004\end{array}$ & $\begin{array}{l}\text { Fissure eruption, lava fountains, ash clouds, lava flow } \\
\text { SVA, suspicious weather cloud on satellite image } \\
\text { SVA, seismic swarm }\end{array}$ \\
\hline Akutan & $\begin{array}{l}1992 \\
1996 \\
1998 \\
2003\end{array}$ & $\begin{array}{l}\text { SVA, steam/ash emissions } \\
\text { Intensive seismicity, ground cracking } \\
\text { SVA, tremor-like seismicity } \\
\text { SVA, anomalous steam plume }\end{array}$ \\
\hline Makushin & $\begin{array}{l}1993 \\
1994\end{array}$ & $\begin{array}{l}\text { Minor phreatic } \\
\text { SVA, PIREP of minor steam/ash }\end{array}$ \\
\hline
\end{tabular}


Table 4b. Compilation by volcano for particular years included in an Alaska Volcano Observatory Annual Summary, 1992-2006.-Continued

[Suspect Volcanic Activity (SVA) is defined as a report of eruption or possible eruption that is normal fumarolic activity or non-volcanic phenomena, such as weather related. PIREP, pilot weather report]

\begin{tabular}{|c|c|c|}
\hline Volcano & Year mentioned & Type of activity \\
\hline \multicolumn{3}{|c|}{ Alaska (east to west) —Continued } \\
\hline Makushin-Continued & $\begin{array}{l}1995 \\
2001\end{array}$ & $\begin{array}{l}\text { SVA, steam plume } \\
\text { SVA, increase in seismicity }\end{array}$ \\
\hline Bogoslof & 1992 & Dome extrusion, ash and steam emissions \\
\hline Okmok & $\begin{array}{l}1997 \\
2001\end{array}$ & $\begin{array}{l}\text { Strombolian eruption } \\
\text { SVA, seismic swarm }\end{array}$ \\
\hline Vsevidof & 1999 & SVA, sighting of ash after regional earthquake \\
\hline Cleveland & $\begin{array}{l}1994 \\
1997 \\
2001 \\
2005 \\
2006\end{array}$ & $\begin{array}{l}\text { SVA, possible steam/ash emission } \\
\text { Minor eruption, steam/ash } \\
\text { Eruption; gas/ash, lava/debris flows } \\
\text { Intermittent explosions } \\
\text { Intermittent explosions }\end{array}$ \\
\hline Amukta & $\begin{array}{l}1996 \\
1997\end{array}$ & $\begin{array}{l}\text { Small eruption; ash emission } \\
\text { SVA, PIREP of small ash eruption }\end{array}$ \\
\hline Seguam/Pyre Peak & $\begin{array}{l}1992 \\
1993\end{array}$ & $\begin{array}{l}\text { Minor eruptive activity, steam/ash emissions } \\
\text { Fissure eruption produces lava flow and ash cloud }\end{array}$ \\
\hline Kliuchef (Atka) & $\begin{array}{l}1993 \\
1995\end{array}$ & $\begin{array}{l}\text { SVA, audible rumbling, strong sulfur odor } \\
\text { SVA, large steam plume, strong sulfur odor }\end{array}$ \\
\hline Korovin (Atka) & $\begin{array}{l}1996 \\
1998 \\
2005 \\
2006\end{array}$ & $\begin{array}{l}\text { SVA, PIREP of ash cloud, suspicious cloud on satellite image } \\
\text { Eruption; explosions and ash fall } \\
\text { Minor eruption, steam and ash } \\
\text { Seismic swarms, uplift, increased fumarolic activity }\end{array}$ \\
\hline Kasatochi & $\begin{array}{l}2005 \\
2006\end{array}$ & $\begin{array}{l}\text { SVA, unusual bubbling; floating scum on crater lake } \\
\text { Continued bubbling in intracaldera lake }\end{array}$ \\
\hline Great Sitkin & $\begin{array}{l}2001 \\
2002\end{array}$ & $\begin{array}{l}\text { SVA, anomalous seismicity } \\
\text { SVA, seismic swarm, tremor }\end{array}$ \\
\hline Kanaga & $\begin{array}{l}1993 \\
1994 \\
1995 \\
1996\end{array}$ & $\begin{array}{l}\text { SVA, increased steaming } \\
\text { Eruption; steam/ash and lava flow } \\
\text { Minor eruptive activity, steam/ash and lava } \\
\text { Possible eruption and ash emission }\end{array}$ \\
\hline Tanaga & 2005 & SVA, anomalous seismicity, including a period of tremor \\
\hline \multicolumn{3}{|c|}{ Kamchatka and northern Kurile Islands (north to south) } \\
\hline Sheveluch & $\begin{array}{l}1997 \\
1998 \\
1999 \\
2000 \\
2001 \\
2002 \\
2003 \\
2004 \\
2005 \\
2006\end{array}$ & $\begin{array}{l}\text { Dome extrusion } \\
\text { Lava dome growth } \\
\text { Lava dome growth and collapse, ash } \\
\text { Lava dome growth, ash } \\
\text { Lava dome growth and collapse, ash } \\
\text { Lava dome growth, ash, pyroclastic flows } \\
\text { Lava dome growth, ash, pyroclastic flows, lahar } \\
\text { Lava dome growth, pyroclastic flows, lahars, ash } \\
\text { Lava dome growth, dome collapse, pyroclastic flows, ash } \\
\text { Lava dome growth, dome collapse, explosions }\end{array}$ \\
\hline Klyuchevskoy & $\begin{array}{l}1996 \\
1997 \\
1998\end{array}$ & $\begin{array}{l}\text { Gas/ash eruption } \\
\text { Gas/ash eruption } \\
\text { Gas/ash eruption }\end{array}$ \\
\hline
\end{tabular}


Table 4b. Compilation by volcano for particular years included in an Alaska Volcano Observatory Annual Summary, 1992-2006.-Continued

[Suspect Volcanic Activity (SVA) is defined as a report of eruption or possible eruption that is normal fumarolic activity or non-volcanic phenomena, such as weather related. PIREP, pilot weather report]

\begin{tabular}{|c|c|c|}
\hline Volcano & Year mentioned & Type of activity \\
\hline \multicolumn{3}{|c|}{ Kamchatka and northern Kurile Islands (north to south)—Continued } \\
\hline \multirow[t]{8}{*}{ Klyuchevskoy-Continued } & 1999 & Gas/ash eruption \\
\hline & 2000 & Vulcanian explosions \\
\hline & 2001 & Fumarolic plume \\
\hline & 2002 & Elevated seismicity, gas-rich explosion \\
\hline & 2003 & Elevated seismicity, ash explosion, Strombolian activity \\
\hline & 2004 & Elevated seismicity \\
\hline & 2005 & Strombolian eruption, lava flows, lahars \\
\hline & 2006 & Increased seismicity, thermal anomaly, no eruption \\
\hline \multirow[t]{12}{*}{ Bezymianny } & 1995 & Explosive eruption \\
\hline & 1996 & Lava extrusion \\
\hline & 1997 & Dome collapse and explosive eruption \\
\hline & 1998 & Degassing and spalling of new dome \\
\hline & 1999 & Degassing and spalling of new dome, ash \\
\hline & 2000 & Dome growth, explosive eruption \\
\hline & 2001 & Accelerated dome growth, pyroclastic flows \\
\hline & 2002 & Accelerated dome growth, explosions, pyroclastic flows \\
\hline & 2003 & Dome growth and explosive collapse \\
\hline & 2004 & Minor explosive eruptions, gas and steam emissions \\
\hline & 2005 & Dome growth continues, two explosive episodes \\
\hline & 2006 & Dome growth continues, two explosive episodes \\
\hline \multirow[t]{12}{*}{ Karymsky } & 1995 & Increased seismicity \\
\hline & 1996 & Explosive eruption \\
\hline & 1997 & Low level Strombolian eruptions \\
\hline & 1998 & Low level Strombolian eruptions \\
\hline & 1999 & Low level Vulcanian and Strombolian eruptions \\
\hline & 2000 & Low level Vulcanian and Strombolian eruptions \\
\hline & 2001 & Low level Vulcanian and Strombolian eruptions \\
\hline & 2002 & Low level Vulcanian and Strombolian eruptions, explosions, avalanches \\
\hline & 2003 & Vulcanian and Strombolian eruptions intensify \\
\hline & 2004 & Low level Vulcanian and Strombolian eruptions \\
\hline & 2005 & Low level Vulcanian and Strombolian eruptions, explosions, lava, ash fall \\
\hline & 2006 & Low level Vulcanian and Strombolian eruptions \\
\hline \multirow[t]{3}{*}{ Avachinsky } & 1996 & Increased seismicity \\
\hline & 2001 & Increased seismicity, phreatic explosion \\
\hline & 2005 & Increased seismicity, thermal anomalies \\
\hline \multirow[t]{3}{*}{ Mutnovsky } & 1996 & Fumarolic plume \\
\hline & 2000 & Gas and steam explosion \\
\hline & 2005 & Increased fumarolic activity \\
\hline \multirow[t]{2}{*}{ Alaid (Kurile Islands) } & 1996 & Ash plume \\
\hline & 1997 & SVA \\
\hline \multirow[t]{2}{*}{ Ebeko } & 2005 & Increased fumarolic activity and phreatic eruptions \\
\hline & 2006 & Increased fumarolic activity \\
\hline \multirow[t]{2}{*}{ Chikurachki } & 2003 & Strombolian and Vulcanian eruption, ash fall \\
\hline & 2005 & Brief explosion produces ash and ash fall \\
\hline Severgin & 2006 & Phreatic or fumarolic activity \\
\hline Chirinkotan & 2004 & Brief, low-level steam, gas, and ash emission \\
\hline Berga & 2006 & Phreatic or fumarolic activity \\
\hline
\end{tabular}




\section{What is an "eruption"?}

The specific use of the term 'eruption' varies from scientist to scientist and there is no universally agreed-upon definition. Here, we adopt usage of the Smithsonian Institution's Global Volcanism Program, which defines eruptions as, “...events that involve explosive ejections of fragmental material, the effusion of liquid lava, or both. This fragmental material may be old as well as new; the explosive interaction of volcanically generated heat and near-surface water can cause dramatic eruptions without any fresh volcanic material reaching the surface." (http://www.volcano.si.edu/faq/index.cfm?faq=02) The element of this definition we wish to emphasize are the verbs 'eject' and 'effuse' which refer to dynamic surface processes that pose some level of hazard. The presence or absence of often ambiguous 'juvenile material' or fresh magma is not relevant to this use of the term eruption, particularly when communicating a potential hazard which makes no distinction between juvenile and non-juvenile eruption products. This definition would not, however, include passive volcanic degassing or hydrothermal-fluid discharge unless accidental solid fragments are entrained.

\section{What is an "historically active volcano"?}

AVO defines an "active" volcano as a volcanic center that has had an eruption (see above) or period of intense seismic or fumarolic activity that is inferred to reflect magma at shallow levels within the volcano. The "historic" period in Alaska is considered post mid-1700s when written records of volcanic activity were first compiled. We include some volcanoes on our list of 'potentially active' volcanoes that do not exactly fit this criteria because geologic evidence suggests that they have been active within the last few thousand years and as such, although not historically active, they retain a potential for hazardous activity that requires careful monitoring. As geologic understanding of Alaska's volcanoes improves through additional fieldwork and modern radiometric-dating techniques, our list of "active" volcanoes will undoubtedly evolve. A case in point from 2006: Fourpeaked Mountain, thought not to have erupted in the Holocene, produced a phreatic eruption in the fall of 2006. It now ranks as an historically active volcano, despite not appearing on the list prior to 2006. 


\title{
Volcanic Activity in Alaska, Northeast to Southwest along Aleutian Arc
}

\author{
New (?) Klawasi Mud Vent \\ $62^{\circ} 033^{\prime} 31.1 ” \mathrm{~N}$ \\ $145^{\circ} 03^{\prime} 45.2^{\prime} \mathrm{W} \quad$ (GPS coordinates recorded by observer on the ground) \\ Copper River Basin \\ Discharge of cold mud and water
}

AVO was contacted in April 2006 by a long-time Copper River Valley resident to report a possible new mud vent near the Klawasi group mud volcanoes west of Mt. Drum in the Wrangell Mountains (figs. 2 and $\underline{3}$ ). AVO received photos of the feature that had first been seen by backcountry travelers on March 30, 2006. Observers described mud and water erupting gently from a single spot in low-lying, spruceforested terrain. The flow was watery, covering several acres without accumulating much landform relief. Observers Brad Henspeter and his son saw no steaming and found the erupting mixture cold to their touch (they estimated the temperature of the muddy water to be in the 40s [Fahrenheit]; air temperature was reported as below zero). Vegetation in the area showed no signs of chronic stress, also suggesting that the mudflows were new.

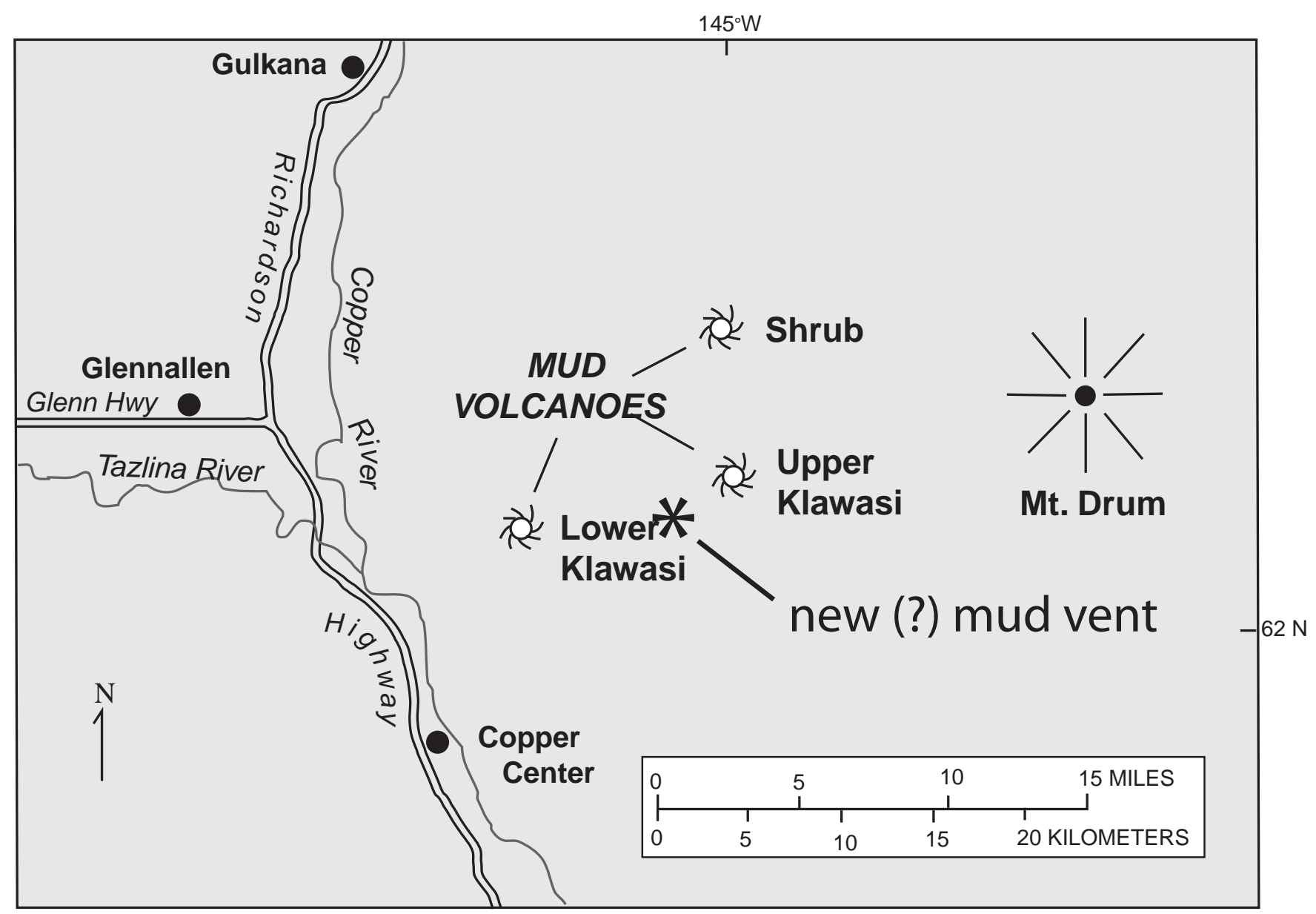

Modified from Richter and others (1995).

Figure 2. Mud volcanoes and possible new mud vent in the Copper River basin. Wrangell St. Elias National Park and Preserve includes land east of the Copper River on this schematic map. 


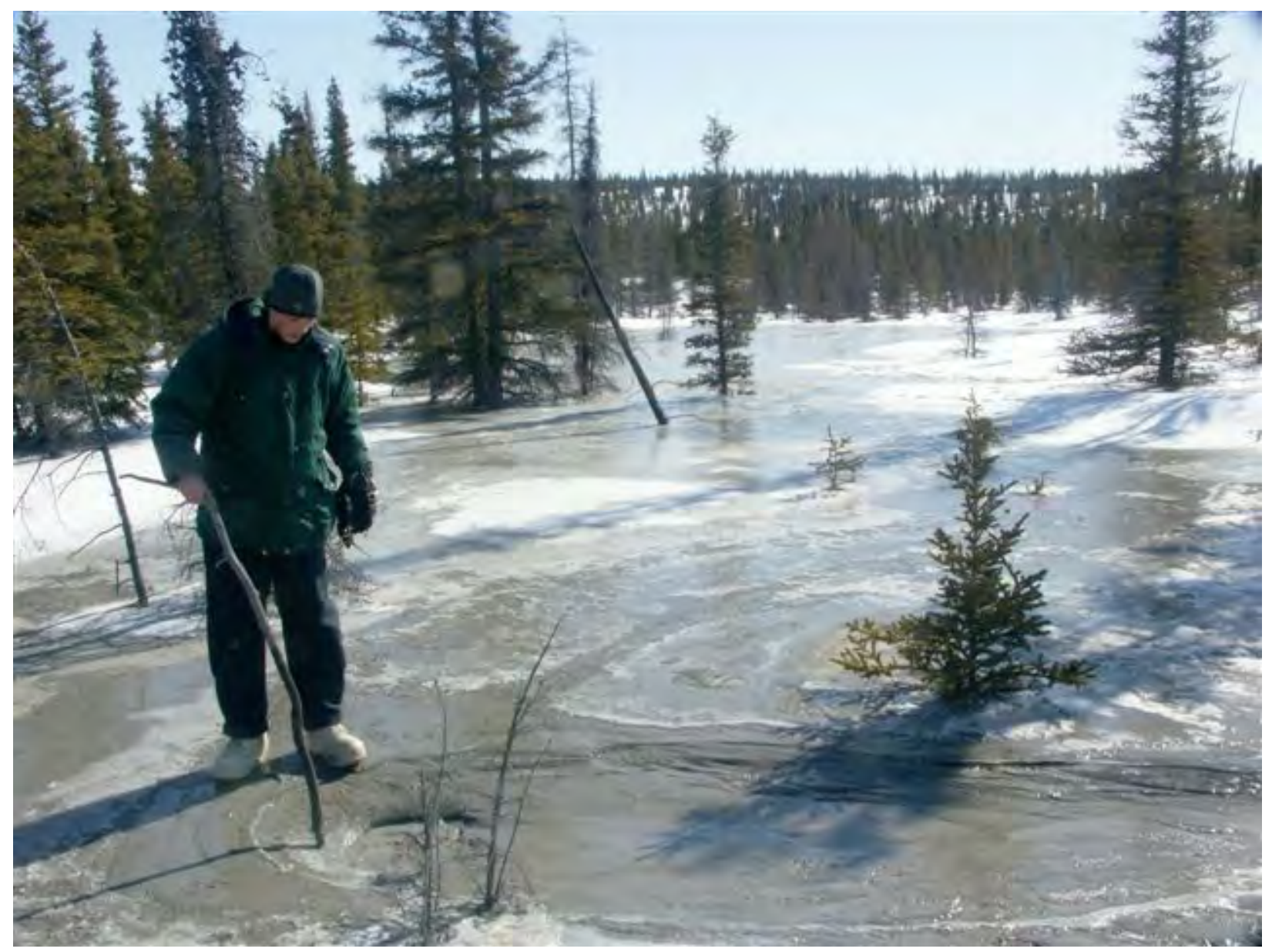

Figure 3. Possible new mud vent. Photograph by B. Henspeter (used with permission), March 30, 2006.

The area of potentially new activity is about $4 \mathrm{~km}$ (2.5 mi) southwest of the long-known and active Upper Klawasi mud vent and about $12 \mathrm{~km}(7.5 \mathrm{mi})$ south-southwest of Shrub, a mud volcano that has been actively erupting since 1997 (fig. 2; McGimsey and Wallace, 1999). U.S. Geological Survey (USGS) scientists have been intermittently documenting the eruption of Shrub, where measured carbon dioxide is derived from a combination of magmatic and metamorphic sources (Nichols and Yehle, 1961; Richter and others, 1998; Sorey and others, 2000). This new and yet unnamed vent is near a cleared seismic line in the middle of remote spruce forest. There is no river nearby that might suggest an overflow origin for this feature. The cause and significance of the mud and water eruption remain uncertain. 


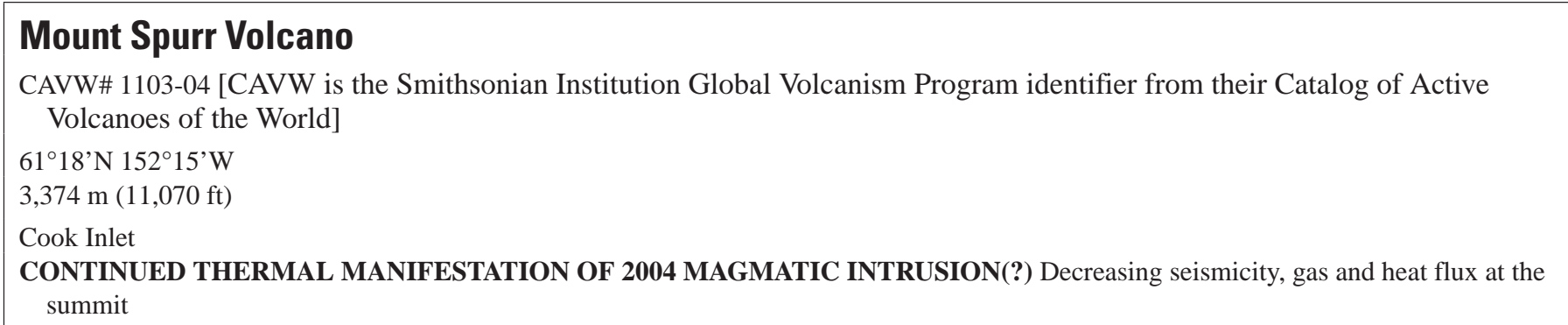

The Level of Concern Color Code for Mount Spurr at the beginning of 2006 was YELLOW due to continued abovebackground seismicity, magmatic degassing, and the presence of an open, warm lake within a 300-m-diameter (980 ft) rockand ice-walled cauldron atop the summit cone. Following months of no significant change in activity, AVO downgraded the Level of Concern from YELLOW to GREEN on February 21. The information release cited a steady decrease in shallow seismicity between April and June 2005, after which earthquake activity remained slightly elevated above background levels through the remainder of 2005 and into 2006. By May 2006, seismicity at Mount Spurr had returned to background levels and remained there with few exceptions through the end of 2006. Intermittent observations permitted sporadic documentation of ongoing changes in the summit area as the geothermal activity continued to disrupt the ice field around the summit cone (table 5).

One seismic swarm of note occurred on April 11 and 12, 2006, when a shallow ( $<5 \mathrm{~km}$ [3 mi] below sea level) swarm of 157 volcano-tectonic earthquakes was detected $1-3 \mathrm{~km}$ (0.6-1.9 mi) west of Mount Spurr. The events occurred over a 19-hour time period (from 20:00 UTC April 11 to 15:00 UTC April 12) and included four, 1-hour-long pulses of activity. Focal mechanisms for the largest events $(\mathrm{Ml}=\sim 2.3)$ were consistent with other historical earthquakes in this area (John Power, USGS, oral commun., 2006).

The summit cauldron (or crater) and warm lake had remained relatively constant in size and character from late August 2005 into early 2006 (Coombs and others, 2006a; McGimsey and others, 2007). Photographs of the lake during overflights throughout the year show a series of stranded shorelines on the northern lake edge indicating lake-level drop sometime before early summer. Additionally, progradation of the shoreline in the northeast sector occurred as fragmental debris rained down the steep, exposed rock in the enclosing crater walls.
Climbers reaching the Mount Spurr summit in March 2006 photographed the milky, blue-green melt lake (fig. 4), and reported noxious, irritating, sulfurous gas (both rotten egg and burned match smells) on the north rim of the cauldron.

AVO scientist Rick Wessels conducted a Forward Looking Infrared Radiometer (FLIR) survey of the Mount Spurr summit, Crater Peak, and the Kidazgeni Glacier on April 14. Thermal areas on the outside of the summit cone ranged from 25 to $45^{\circ} \mathrm{C}$, and several, possibly new areas of steaming were identified on the south side of the summit cone and north of the "flatiron" (Coombs and others, 2006a). Inside the ice cauldron, the most prominent and vigorous of native sulfur-encrusted fumaroles at the northeast shoreline gave temperatures as high as $150^{\circ} \mathrm{C}$ (fig. 5). A long-term feature, a vigorous jet (hereafter named "Jumbo Jet") partially was ringed by dry ground, similar to views in early March (fig. 4). Waves of yellow-tinted material could be seen pulsing out through the water from Jumbo Jet. A minimum FLIR temperature of this roiling zone of water was $25^{\circ} \mathrm{C}$, although the average temperature for the overall lake was $11^{\circ} \mathrm{C}$. On the adjacent shoreline, about a dozen separate fumarolic point sources marked by bright yellow sulfur encrustations were producing high velocity, visible vapor jets. FLIR temperatures were obtained through a thin veil of steam, hence temperatures likely are minimums. Normally steaming areas on the floor of Crater Peak, the historically active flank vent of Mount Spurr $3 \mathrm{~km}$ (1.9 mi) from the summit lake, indicated maximum temperatures of about $45^{\circ} \mathrm{C}$-not a significant change from previous measurements.

More bare rock along the sheer north and west cauldron walls became exposed during the spring and into summer 2006, and the lake remained milky, light blue-green water and mostly ice free (figs. 6 and 7). Beginning in mid-July, AVO observers noted slow accumulation of snow and ice debris on the lake surface, particularly below the southwest cauldron wall. During a July 12 overflight, nearly the entire lake was frozen or snow-covered (fig. 7). 
Table 5. Chronology of events and observations relating to volcanic unrest at Mount Spurr, Alaska, 2004-06.

[Modified from Coombs and others (2006a) and McGimsey and others (2007). AVO, Alaska Volcano Observatory; AST, Alaska Standard Time; ASTER, Advanced Spaceborne Thermal Emission and Reflection Radiometer; FLIR, Forward Looking Infrared Radiometer used to delineate objects of different temperature; ${ }^{\circ} \mathrm{C}$, degrees Celsius; $\mathrm{ft}$, foot; $\mathrm{m}$, meter; $\mathrm{m}^{2}$, square meter; -, no data]

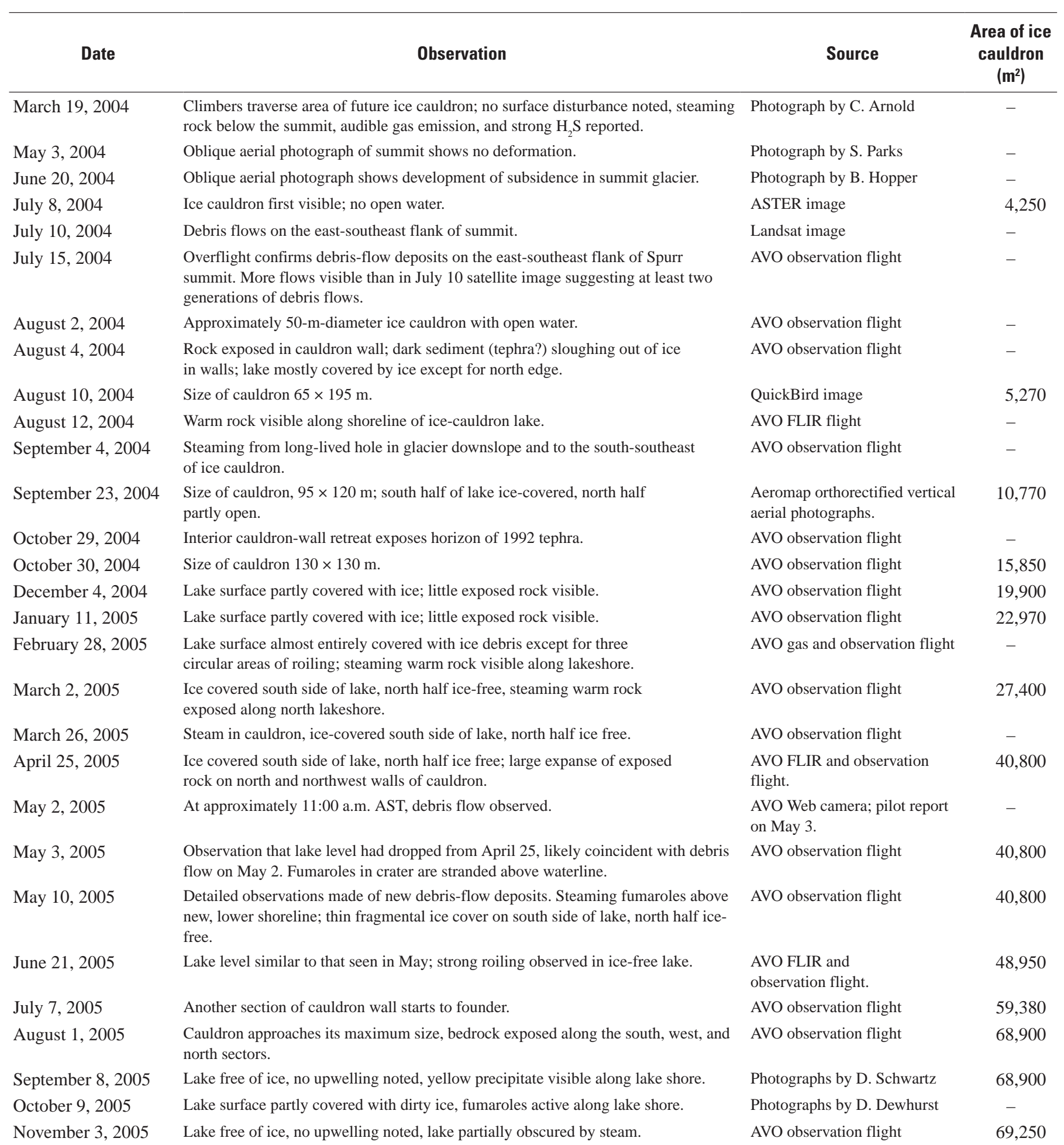


Table 5. Chronology of events and observations relating to volcanic unrest at Mount Spurr, Alaska, 2004-06.-Continued

[Modified from Coombs and others (2006a) and McGimsey and others (2007). AVO, Alaska Volcano Observatory; AST, Alaska Standard Time; ASTER, Advanced Spaceborne Thermal Emission and Reflection Radiometer; FLIR, Forward Looking Infrared Radiometer used to delineate objects of different temperature; ${ }^{\circ} \mathrm{C}$, degrees Celsius; $\mathrm{ft}$, foot; $\mathrm{m}$, meter; $\mathrm{m}^{2}$, square meter; - , no data]

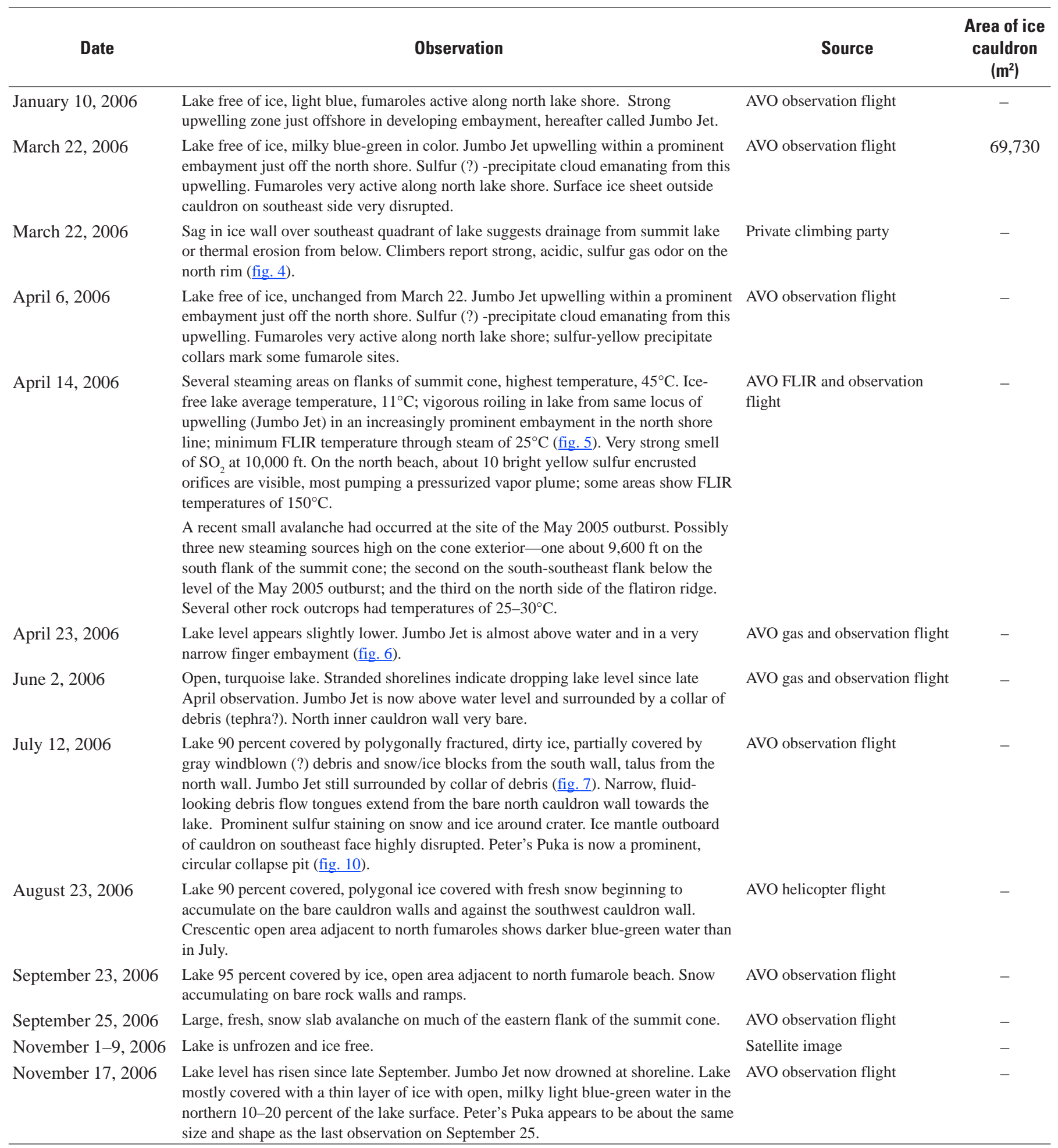




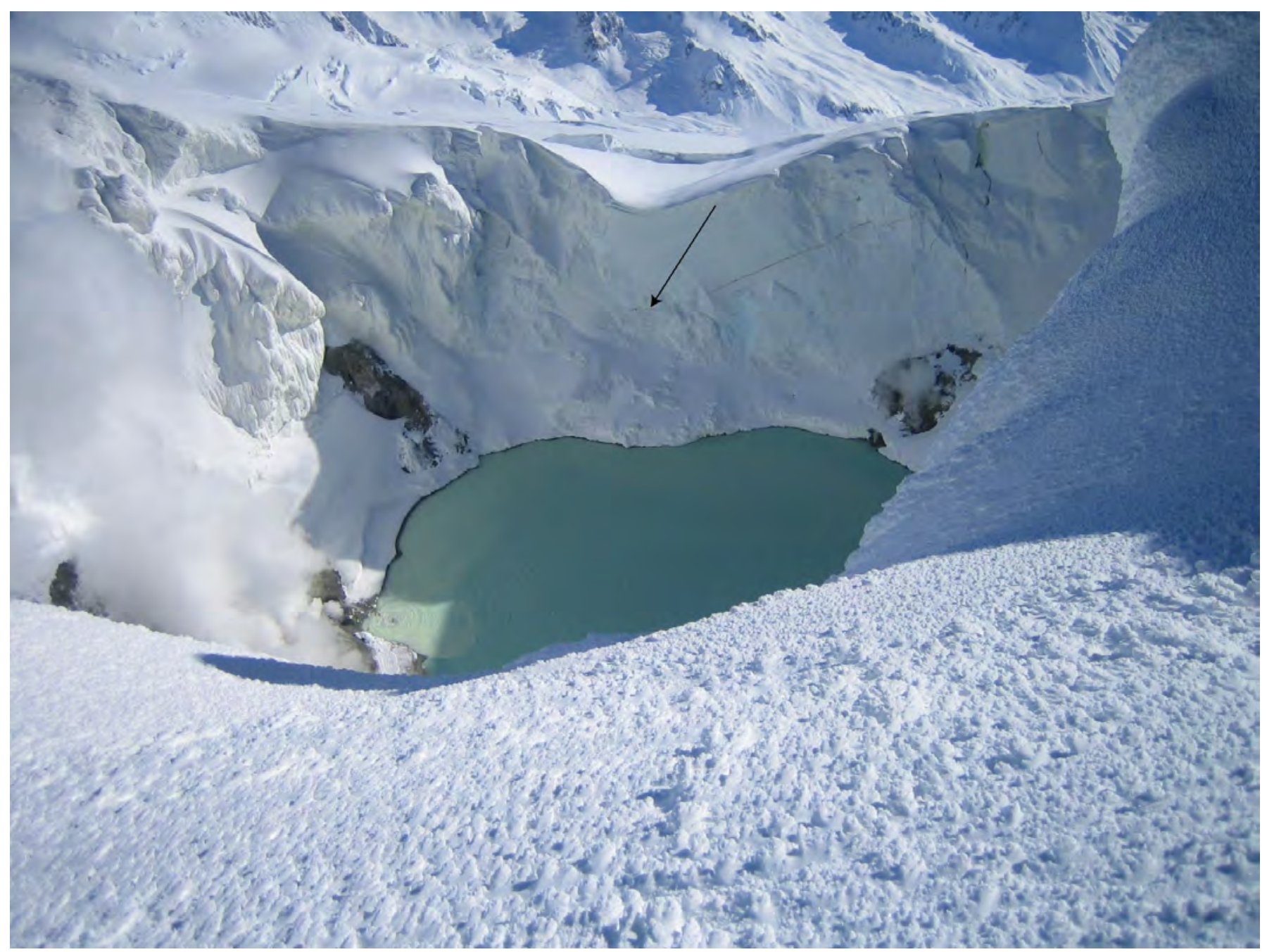

Figure 4. Summit ice cauldron at Mount Spurr, March 2006. View is to the southeast. Note sag in ice on far wall of cauldron, indicated by bend in dark, buried tephra layer (arrow). Coombs and others (2006a) suggest the sag in the ice forming the southeastern rim of the ice cauldron possibly marks a spillway channel for water that overflows the cauldron bedrock basin and travels beneath the ice into the Kidazgeni Glacier drainage. Alternatively, this could be a zone of higher heat flow beneath the ice (Erin Pettit, USGS, oral commun., 2007). Note the plume of yellow precipitate emanating from an area of upwelling in the sunny north shoreline area of the lake at left. Photograph by climber Nathen Bluett (used with permission), March 22, 2006. 


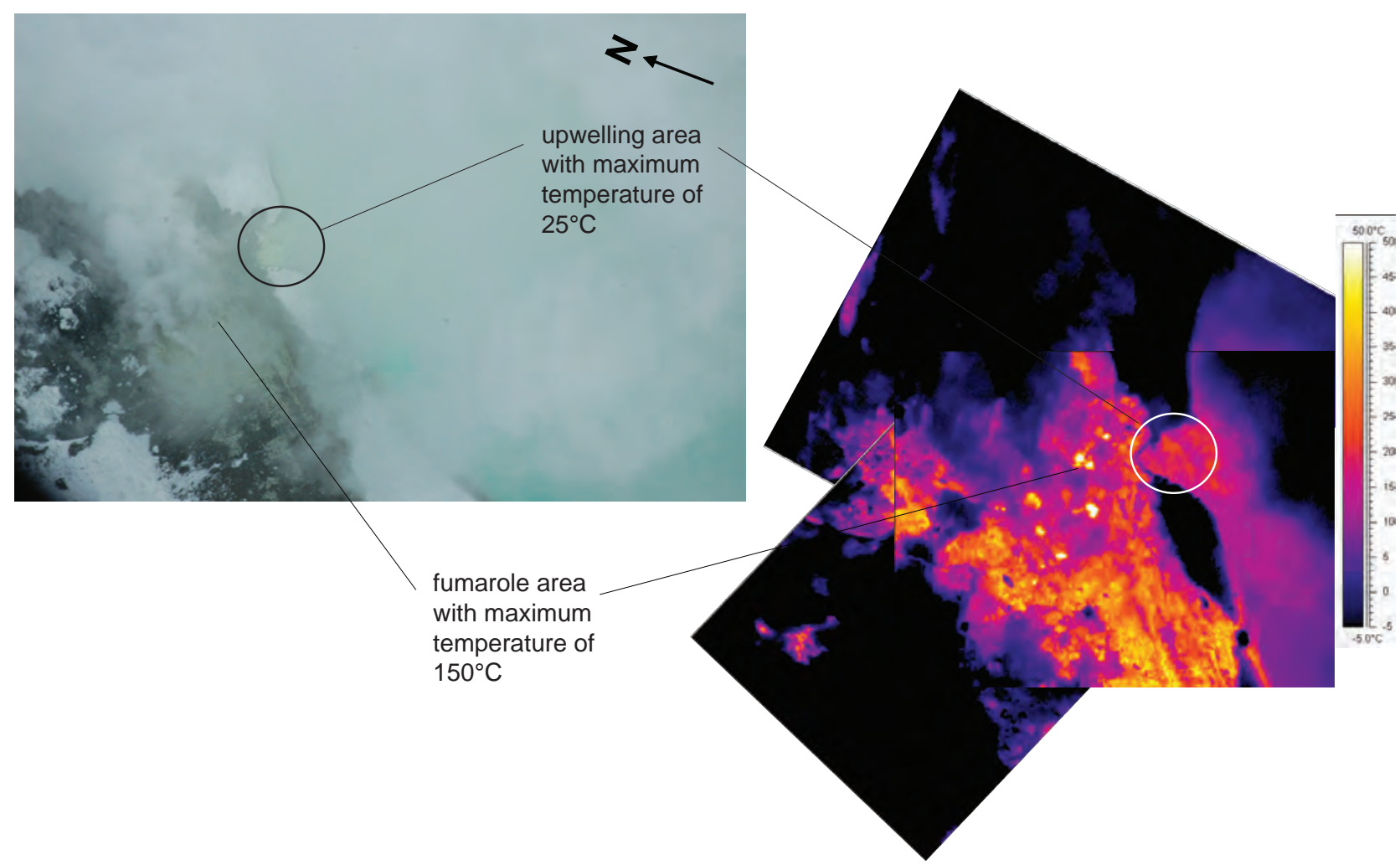

Figure 5. Forward Looking Infrared Radiometer image mosaic (right) and correlative video frame capture (left) of the north shoreline of the warm lake within the summit ice cauldron. Prepared by R.L. Wessels, AVO/USGS, April 14, 2006. Images are oriented in approximately the same direction with north to the upper left. The area of upwelling still submerged at lakeshore (circled) is informally referred to as "Jumbo Jet" and has been the longest-lived, consistently most vigorous fumarolic source in the lake.

The cauldron lake was similarly covered with ice and snow during overflights in late August and into September. Satellite imagery indicated the lake became mostly open again in early November; however, the lake was largely covered when seen again from a fixed wing aircraft on November 17 (table 5). Whether or not this spot observation of an open lake in early November represented a transient heating event or some other process is unclear; the infrequent observations made at irregular intervals make it difficult to discern any systematic trend or cause of ice-cover variations. The last 2006 overflight of Mount Spurr by AVO was on November 17. The lake was open only along a sliver of the northeastern shoreline near the fumarole field. Lake water was still a milky light blue with a prominent yellow particulate plume emanating from
Jumbo Jet. Interestingly, Jumbo Jet was surrounded by water, not dry material as it was in the late summer, indicating a slight rise in lake level from mid-summer into the fall.

The summit cone of Mount Spurr is a locus of many slab avalanches, and one such fresh avalanche was observed during an airborne gas flight on September 25 (fig. 8). Frequent avalanching from the southeastern and southern flanks of the summit cone may in part be due to geothermal heating of the glacier bed and increased melting and instability.

A prominent change in 2006 was an enlargement of a feature called "Peter's Puka," a pit in the ice outside the cauldron that was initially a tensional crevasse on the southeast summit slope during the very early stages of cauldron formation (fig. 9; fig. 10). Over time, the crevasse gradually 


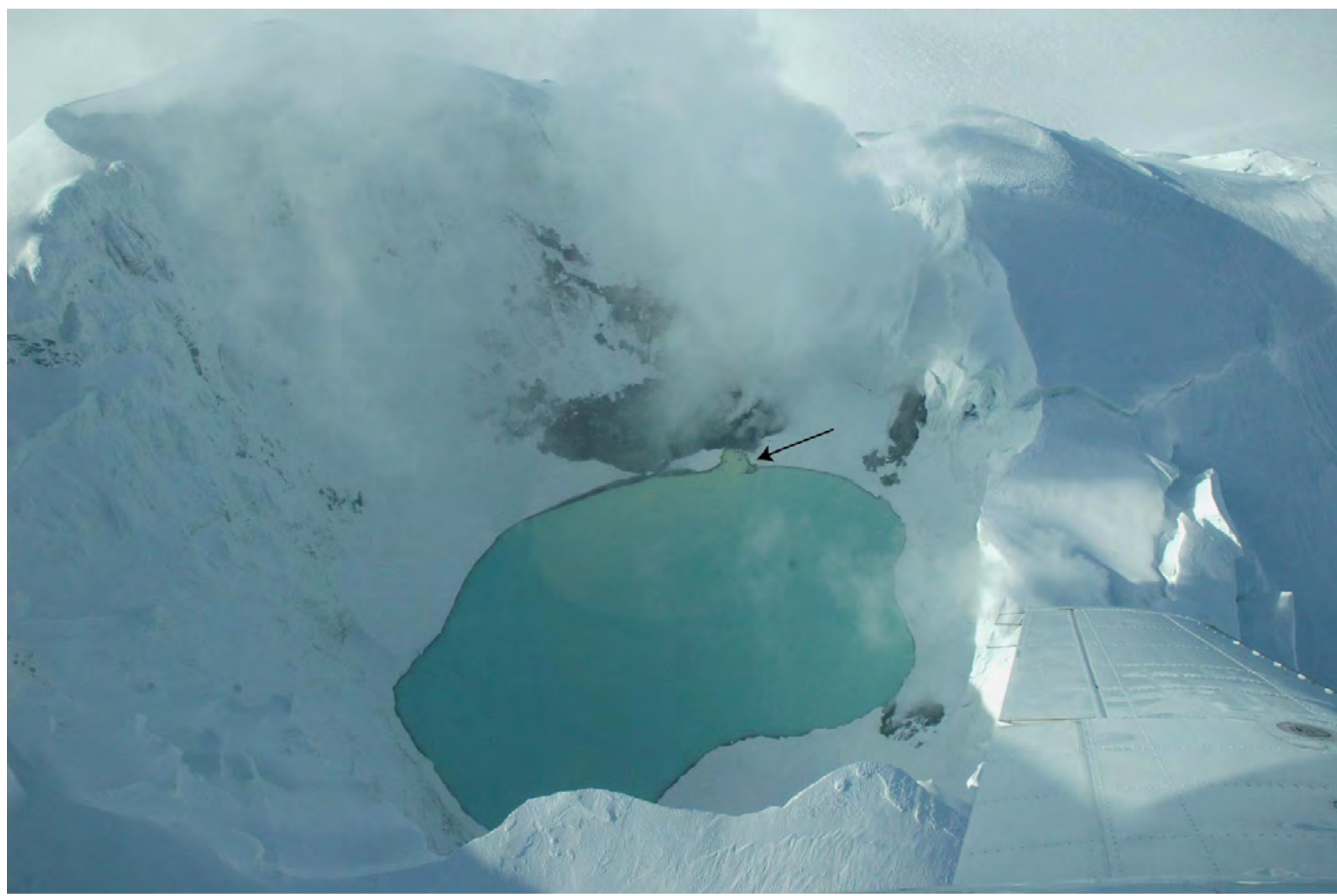

Figure 6. Aerial view of Mount Spurr cauldron, April 2006. The lake is about $200 \mathrm{~m}(660 \mathrm{ft})$ across. Note Jumbo Jet, the prominent fumarole on the north shoreline (arrow), producing a plume of yellow sulfur precipitate extending nearly halfway across the lake. View is to the north. Photograph by C.A. Neal, AVO/USGS, April 23, 2006. AVO database image at URL: http:// www.avo.alaska.edu/image.php?id=12560.

enlarged and became a fairly consistent source of vapor plumes. By the summer of 2006, this feature had become a large cleft and steaming collapse pit in the highly disrupted ice sheet mantling the upper southeast face of the Mount Spurr summit cone (fig. $9 B$ ). Adjacent ice showed clear evidence of thinning and wasting as bare ground became exposed (elevated temperatures were confirmed by FLIR imagery) and the opening of crevasses indicated wholesale slumping and downslope motion of ice and possibly large scale slumping (fig. 10). Immediately upslope of "Peter's Puka" on the southeast rim of the cauldron was the prominent sag in the ice, first noted by climbers in March (fig. 4). The proximity of this sag and the highly disrupted and thermally active "Peter's Puka" area could indicate a previously unknown area of surface thermal activity related to the 2004 event. Alternatively, this corridor may be a preferred pathway for warm water leaking from the summit lake at the base of the ice.

Intermittent airborne measurements of volcanic gases (carbon dioxide, $\mathrm{CO}_{2}$; hydrogen sulfide, $\mathrm{H}_{2} \mathrm{~S}$; and sulfur dioxide, $\mathrm{SO}_{2}$ ) in 2006 indicated small but measurable quantities mostly below levels measured in late 2004 and 2005 (Doukas and McGee, 2007). The AVO web camera and observers on the ground and from the air frequently noted white vapor plumes issuing from the summit crater. Yellow, sulfur-stained snow and ice on the summit crater rim were often reported by passing pilots. AVO also received several pilot reports of sulfurous odors in the vicinity of Mount Spurr over the course of 2006 


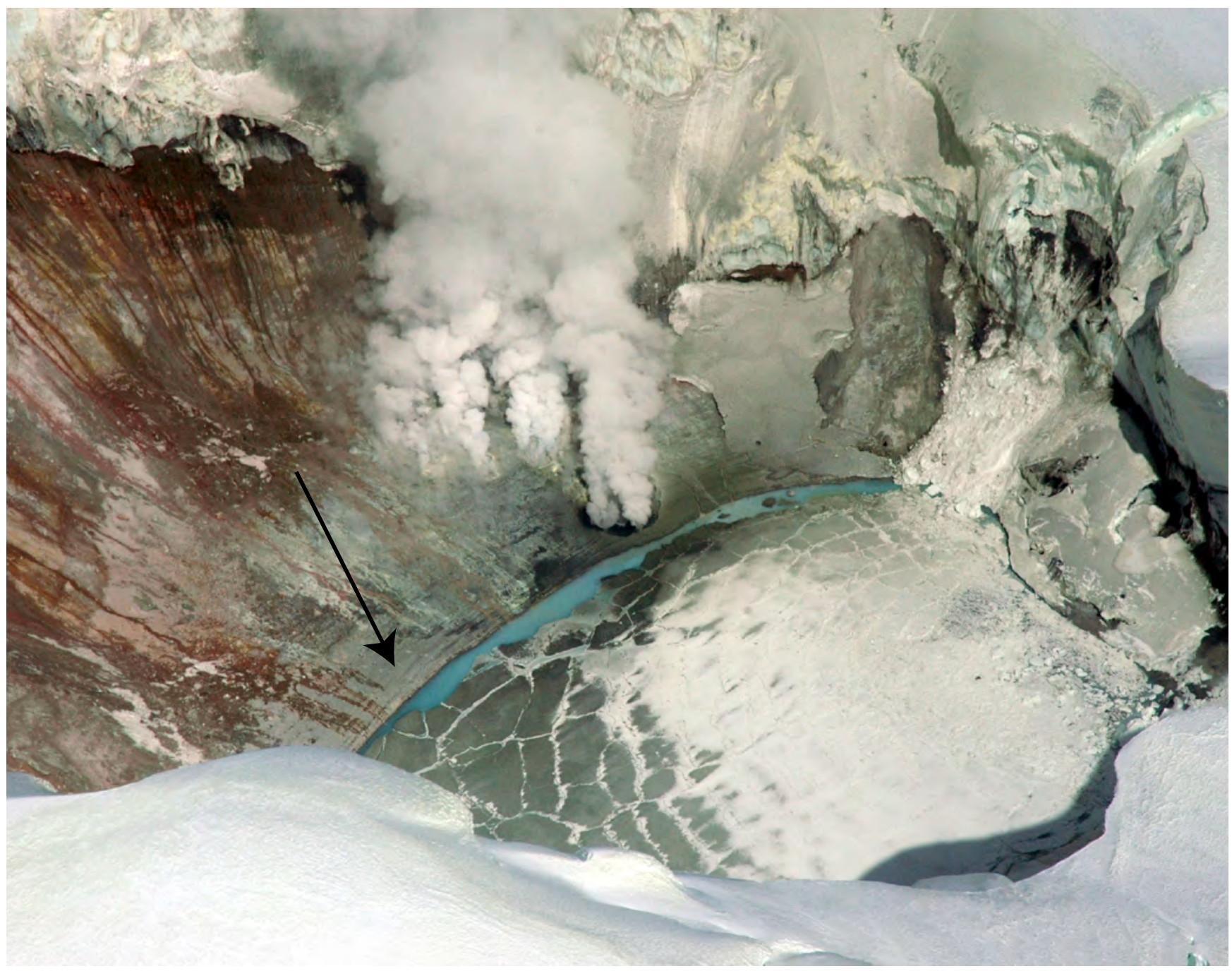

Figure 7. Aerial view of Mount Spurr ice cauldron looking northeast showing area of pressurized fumarolic jets on the sloping crater floor. Note dry ground surrounding Jumbo Jet along the shoreline. The circular, slightly raised rim indicates possible sustained ejection or remobilization of debris by pressurized fumarolic emission. Multicolored debris flow tongues extend down the colluvial ramp at the base of the north crater wall. Sulfur-tinted ice and snow cling to the cauldron walls and rim. Note strandlines along north shoreline (arrow) reflecting successive drops in lake level during the first half of 2006. Patches of dark debris atop lake ice likely reflects wind-blown material from exposed rock, talus, and beach deposits. Fracture pattern of ice indicates perturbation of the ice sheet by wind, current, or freeze-thaw. Photograph by R.G. McGimsey, AVO/USGS, July 12, 2006. AVO database image at URL: http://www.avo.alaska.edu/image.php?id=10765.

In April 2006, AVO scientists sampled water discharging from the west arm of the Kidazgeni Glacier that drains the southeast sector of the summit cone-the area most profoundly impacted by repeated debris outbursts since 2004 (fig. 11). A geothermal fluid input is confirmed by high anion content and high conductivity. However, the water does not appear to be the extremely acidic composition expected if derived from the sulfur-rich summit lake (table 6; W.C. Evans, USGS, written commun., 2006). Prior to this sampling, however, only the weak thermal springs southwest of Crater Peak (fig. 11), described decades ago by Turner and Wescott (1986) and Motyka and others (1993), were known as a source of geothermal waters at Mount Spurr. It is possible that the geothermal signature in the Kidazgeni outlet reflects a previously unknown Crater Peak source and not input from the Spurr summit system. Additional work is needed to more fully understand this hydrothermal system and potential hydrologic pathways within and beneath ice and volcanic rock at Mount Spurr. 


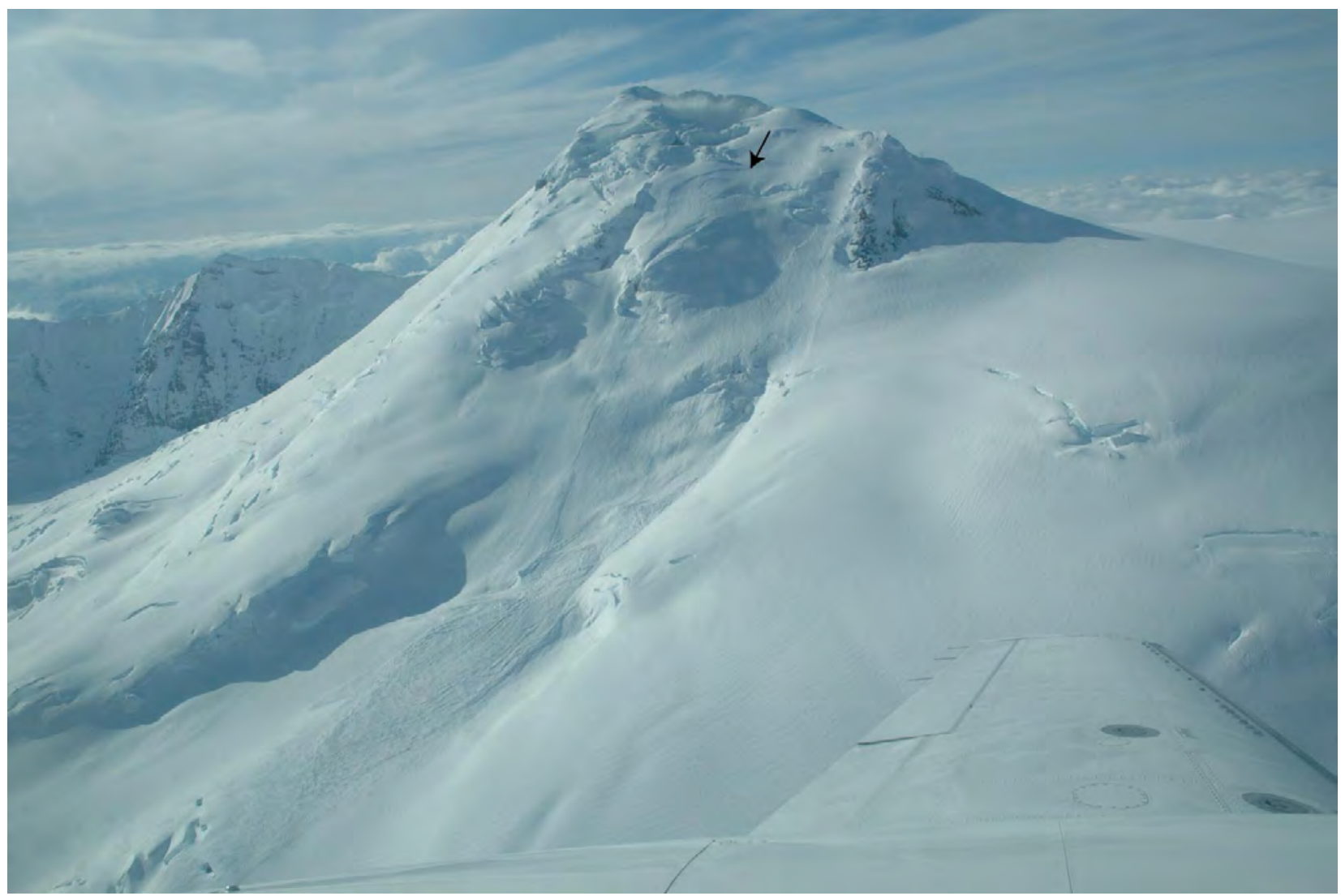

Figure 8. Southeast flank of Mount Spurr summit cone showing slab avalanche. Arrow indicates avalanche scar. Photograph by M.P. Doukas, AVO/USGS, September 25, 2006. AV0 database image at URL: http://www.avo.alaska.edu/ image. php?id=11389.

Table 6. Chemical analyses of water sampled at the Crater Creek warm springs and the Kidazgeni Glacier outlet stream.

[See figure 11 for sampling site location. Analyses by M.A. Huebner, U.S. Geological Survey, Menlo Park, California. UTM, Universal Transverse Mercator; $\mu \mathrm{S} / \mathrm{cm}$, microsiemens per centimeter; ${ }^{\circ} \mathrm{C}$, degrees Celsius; $\mathrm{mg} / \mathrm{L}$, milligrams per liter; nm, not measured; <, less than]

\begin{tabular}{|c|c|c|c|}
\hline $\begin{array}{l}\text { Field parameters and } \\
\text { chemical analysis }\end{array}$ & Upper Crater Creek & Lower Crater Creek & $\begin{array}{c}\text { Kidazgeni Glacier Outflow } \\
\text { O6SPCN001A }\end{array}$ \\
\hline \multicolumn{4}{|l|}{ Field parameters } \\
\hline Date sampled & $6-26-05$ & $06-26-05$ & 04-14-06 \\
\hline Sampled by & Waythomas and Wallace & Waythomas and Wallace & Neal \\
\hline UTM north (N. latitude) & 6789737 (61.239796) & $6789295(61.235847)$ & (61.209917) \\
\hline UTM east (W. longitude) & $541018(152.23584)$ & $540825(152.23925)$ & (152.178948) \\
\hline Datum & WGS 84 & WGS 84 & WGS 84 \\
\hline \multicolumn{4}{|l|}{ Chemical analysis } \\
\hline Conductivity $(\mu \mathrm{S} / \mathrm{cm})$ & 2,320 & 1,653 & 1,000 \\
\hline $\mathrm{pH}$, field (units) & 8.3 & 7.4 & 8.0 \\
\hline pH, laboratory (units) & 7.63 & 8.05 & $\mathrm{~nm}$ \\
\hline Temperature $\left({ }^{\circ} \mathrm{C}\right)$ & 23.0 & 27.3 & $11.8-12.3$ \\
\hline Fluoride (mg/L) & 0.56 & 0.40 & 0.54 \\
\hline Chloride $(\mathrm{mg} / \mathrm{L})$ & 320 & 370 & 116 \\
\hline Sulfate $(\mathrm{mg} / \mathrm{L})$ & 150 & 260 & 122 \\
\hline Bromine (mg/L) & 0.88 & 0.96 & 0.18 \\
\hline Nitrate as nitrogen $(\mathrm{mg} / \mathrm{L})$ & $<0.1$ & $<1.1$ & 0.08 \\
\hline Phosphate as phosphorus (mg/L) & $<0.1$ & $<0.1$ & $<0.1$ \\
\hline Bicarbonate as $\mathrm{HCO}_{3}(\mathrm{mg} / \mathrm{L})$ & 238 & 493 & $\mathrm{~nm}$ \\
\hline
\end{tabular}




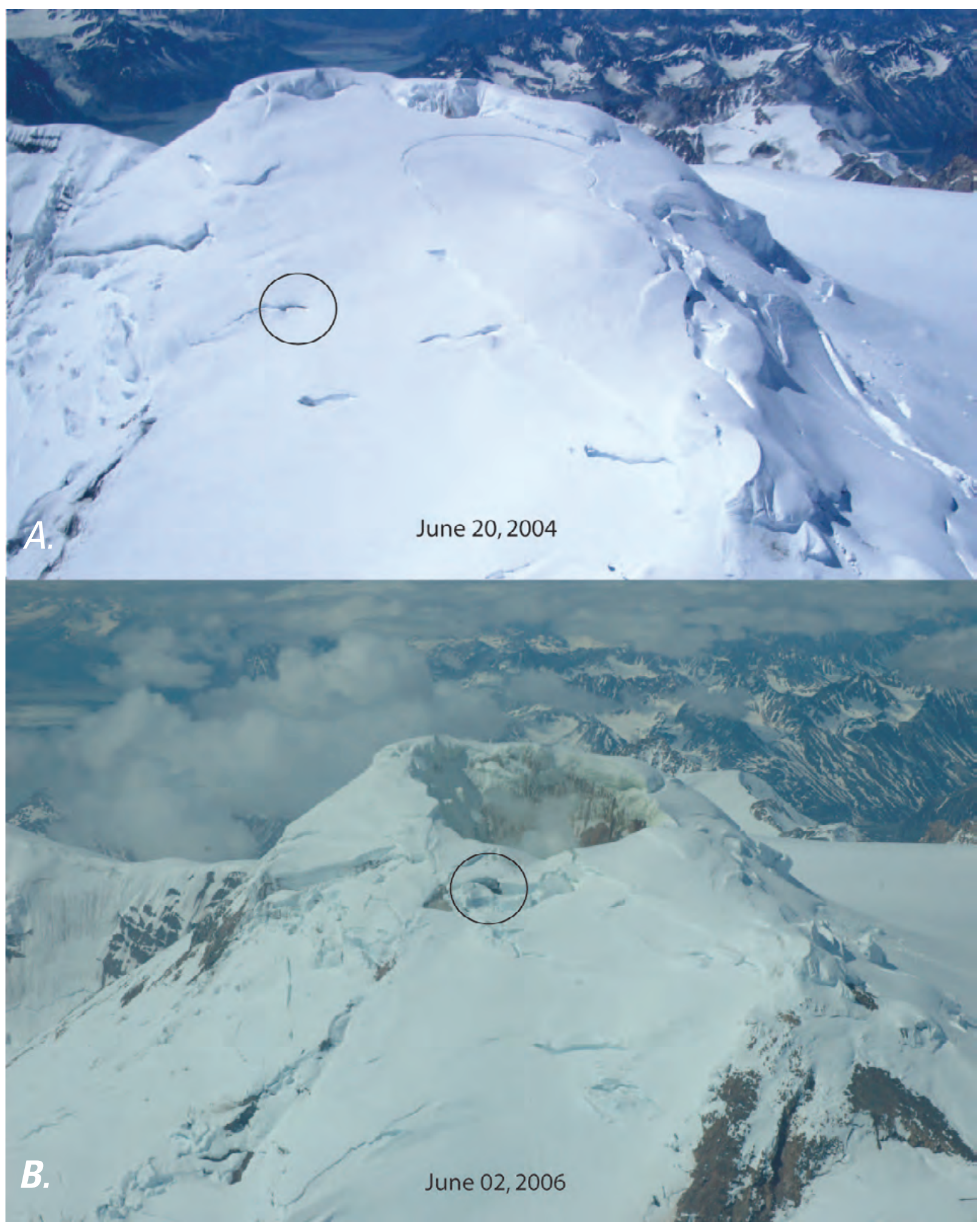

Figure 9. View looking northwest of changes at Mount Spurr summit immediately prior to cauldron opening in June 2004 $(A)$ to growth of the cauldron to maximum size 2 years later in June $2006(B)$. Circled in black in both photographs is the feature "Peter's Puka" discussed in text. Photograph $A$ by B. Hopper (used with permission), June 20, 2004. Photograph $B$ by R.G. McGimsey, AVO/USGS, June 2, 2006. AVO database image at URL: http://www.avo.alaska.edu/image.php?id=10150. 


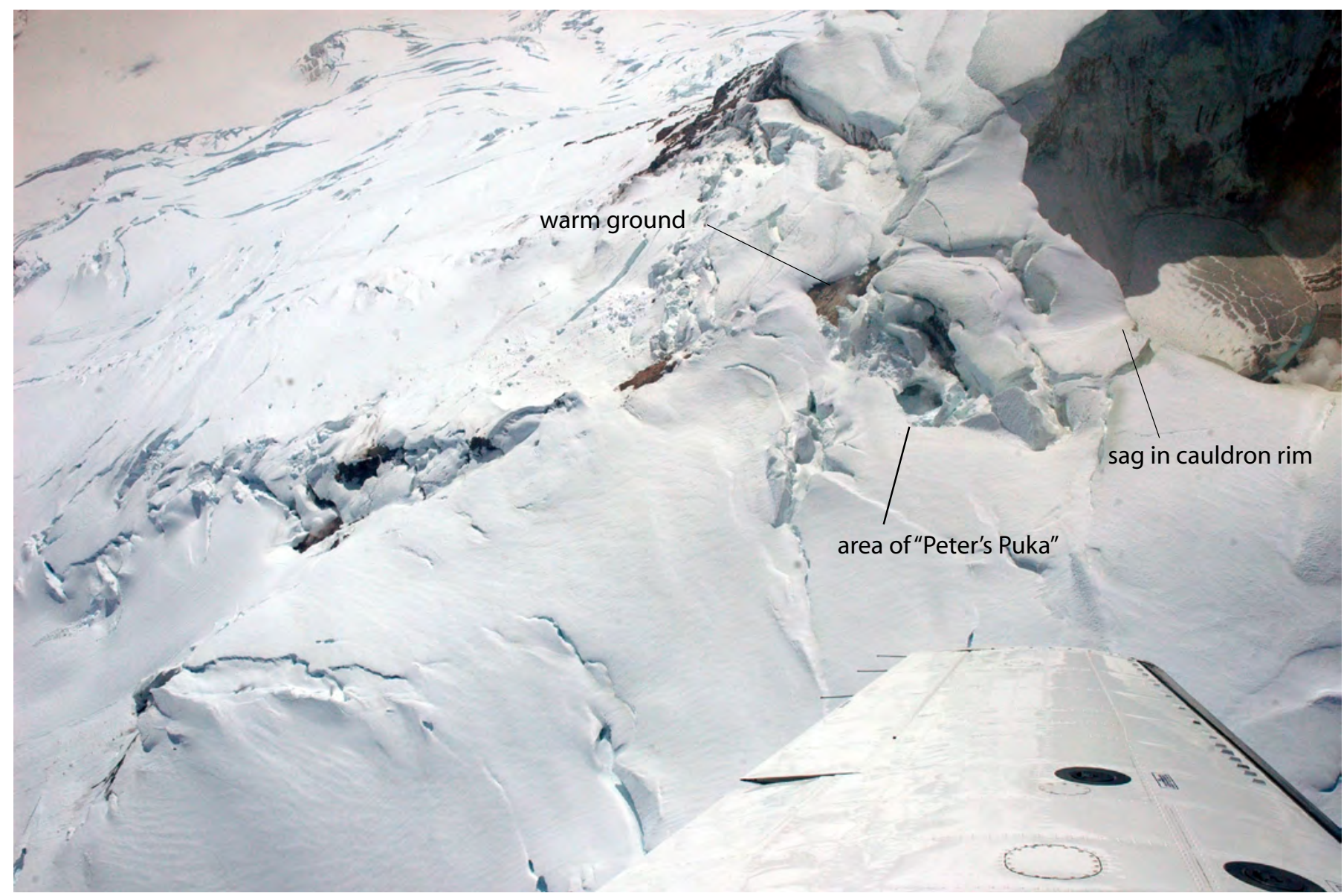

Figure 10. Oblique aerial view of the upper southeast flank of the Mount Spurr summit cone. Much of the cauldron and ice-covered lake visible at upper right. Photograph by R.G. McGimsey, AVO/USGS, July 12, 2006. AVO database image at URL: http://www.avo.alaska. edu/image.php?id=10776.

Despite the return to Level of Concern Color Code GREEN in early 2006, AVO's information release included commentary on the nature of ongoing volcano hazards at Mount Spurr, indicating that conditions remained dangerous for skiers, snowboarders, mountaineers, pilots, and other visitors. The release described a number of potential hazards including unstable snow and ice likely to persist in and around the summit area, especially near the unstable walls of the cauldron; volcanic gas; occasional felt earthquakes large enough to disturb steep or unstable areas of ice and snow; and the potential for water still impounded in the summit cauldron to produce floods of debris or water on the upper flanks of the summit cone, especially in the southeast quadrant.

Ongoing geothermal activity at the Mount Spurr summit produced occasional dramatic views of the fumarolic plume from the Kenai Peninsula and Anchorage (fig. 12). 


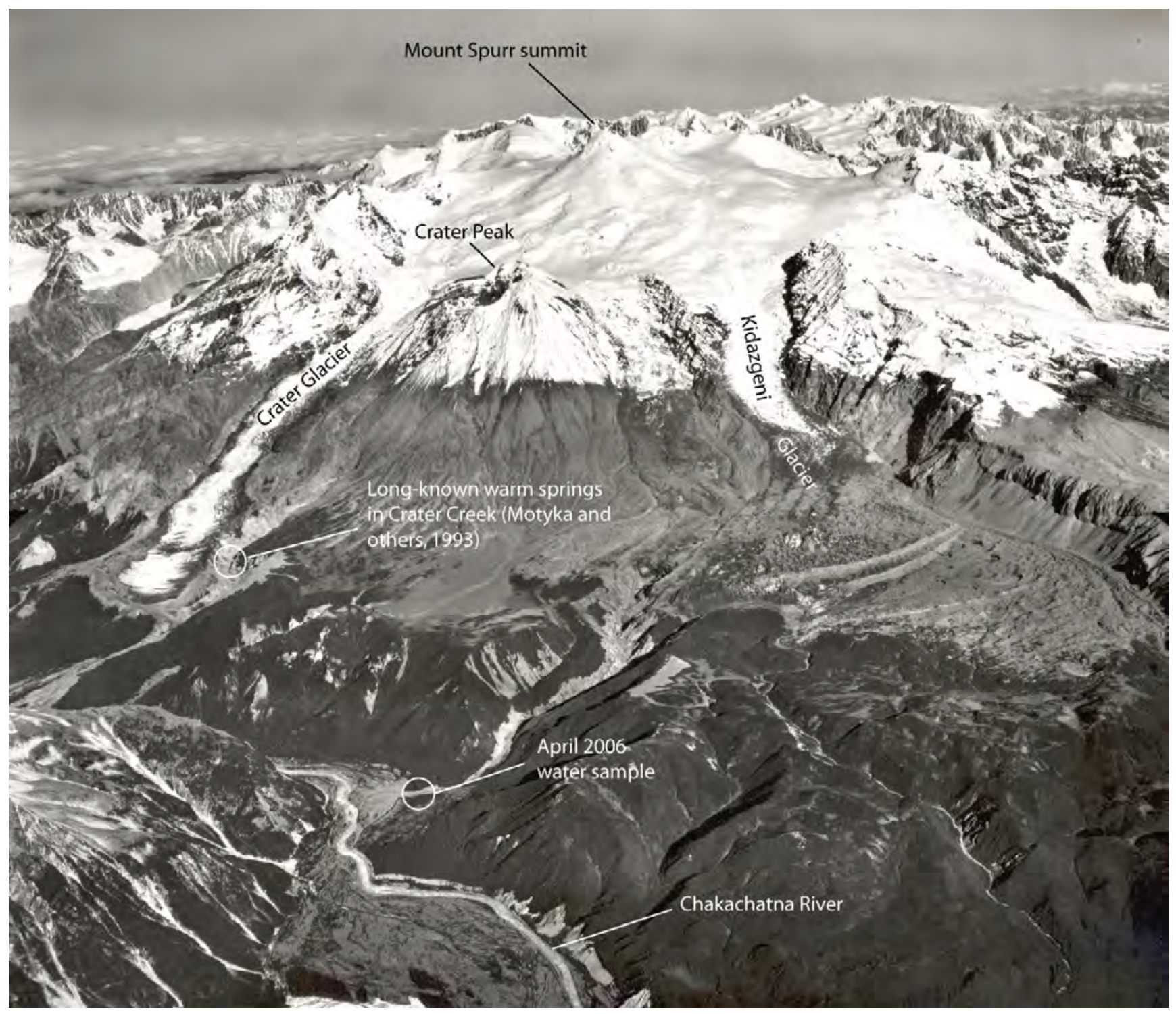

Figure 11. Southern flank of Mount Spurr volcanic complex showing the summit cone, summit caldera ice field, Kidazgeni Glacier, Crater Peak, and location of hydrothermal water sample collected on April 14, 2006. Approximate location of Crater Creek thermal springs also circled. Photograph by A. Post, USGS, September 4, 1964. AVO database image at URL: http://www.avo. alaska.edu/image. php?id=1244. 


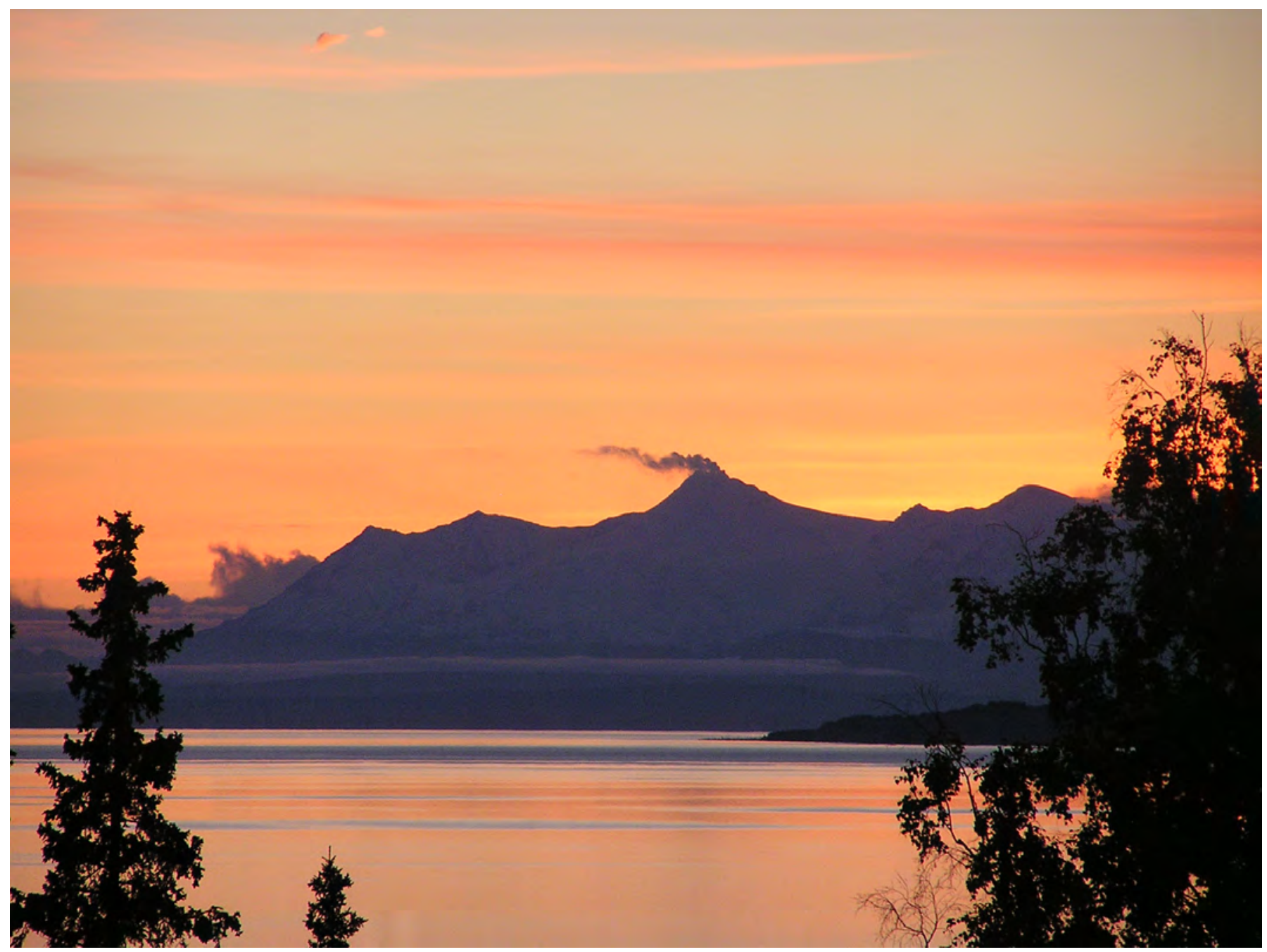

Figure 12. Fumarolic plume trailing to the south from Mount Spurr as seen from Anchorage, September 10, 2006. Photograph by James Copen (used with permission).

Mount Spurr, a 3,374-m-high (11,070 ft) ice- and snowcovered stratovolcano, is $125 \mathrm{~km}$ (80 mi) west of Anchorage. Explosive historical eruptions occurred in 1953 and 1992 from Crater Peak, a satellite vent $3 \mathrm{~km}(1.9 \mathrm{mi})$ south of Spurr's summit (Keith, 1995 and references therein). Each of these eruptive phases produced ash falls on populated areas of south-central Alaska. The summit of Mount Spurr is a largely ice-covered feature previously interpreted as a lava-dome complex (Nye and Turner, 1990); the last known significant eruption based on correlation of tephra deposits was about 5,200 years ago (Riehle, 1985). The current activity is the first well-documented historical unrest related to the true summit of Mount Spurr (Power, 2004). 


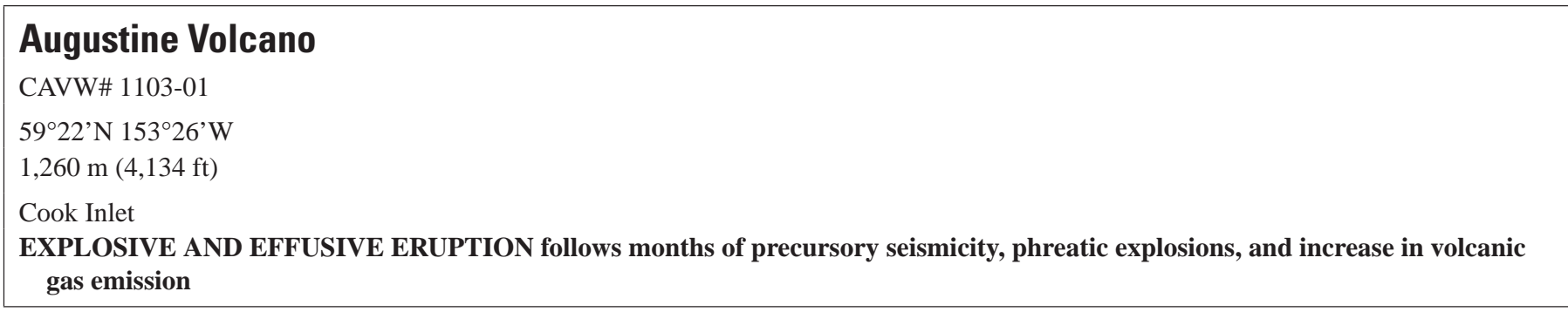

Cook Inlet's most active stratovolcano, Mount St. Augustine, transitioned from mild unrest in 2005 into a fullblown explosive and effusive eruption in the first 3 months of 2006 (Power and others, 2006). Following several months of precursory seismicity, deformation, increased fumarolic and degassing activity in the summit crater, and a series of small phreatic eruptions in December 2005, a vent-clearing explosion on January 11 heralded the beginning of the main eruptive phase (Cervelli and others, 2006; Power and others, 2006). Over the course of the next 20 days, 13 explosions sent ash between 4 and $15 \mathrm{~km}(13,000$ and 50,000 ft) ASL (figs. 13 and 14). Ash clouds drifted in all directions from the volcano, but predominantly to the northwest, northeast, east, and southeast, dusting several communities with less than 1 $\mathrm{mm}$ of ash (Wallace and others, 2006). On-island, pyroclastic flows, surges, avalanches, ash fall, and ballistic showers swept most of the volcano's flanks at one time or another. Interaction of hot pyroclastic debris with snow and ice on the volcano produced mixed avalanches and lahars, some of which reached the sea (Bull and others, 2006; Coombs and others, 2006b). A new lava dome was first sighted in the summit crater on January 16 (fig. 15); however, seismicity reflective of dome growth was noted as early as January 12 (Power and others, 2006).

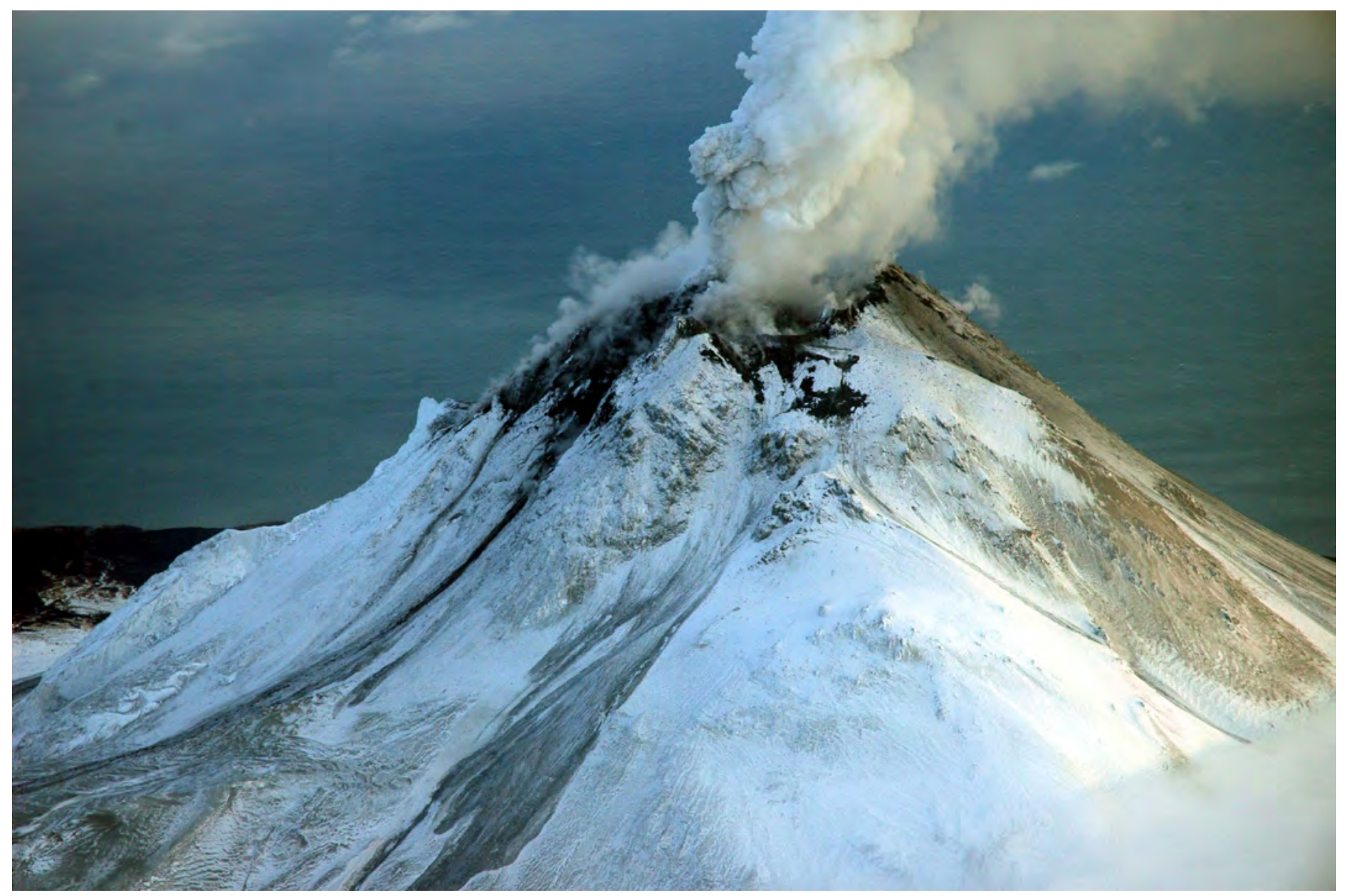

Figure 13. Aerial view of the flank of Augustine Volcano, January 12, 2006. Note lobes of mixed snow and tephra avalanche deposits. Photograph by R.G. McGimsey, AVO/USGS. AVO database image at URL: http://www.avo.alaska.edu/image.php?id=5931. 


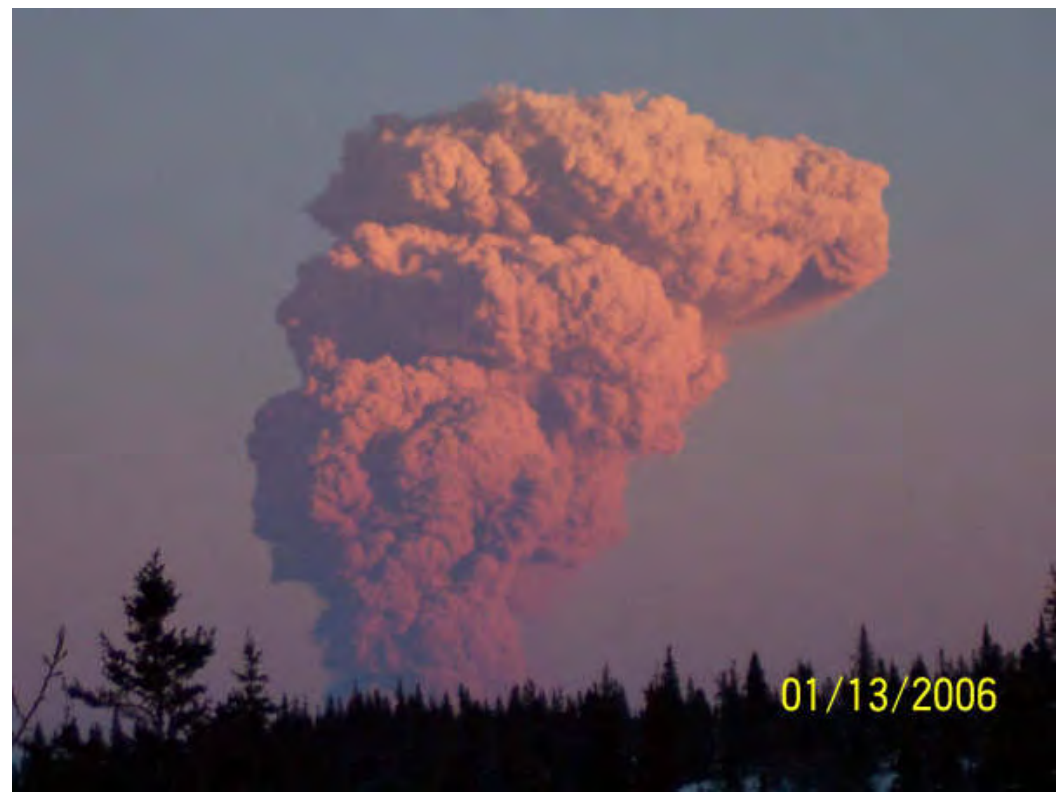

Figure 14. Eruption cloud from Augustine Volcano as seen from Kokhanok, Alaska, January 13,2006 . Kokhanok is on the southeast shoreline of Lake lliamna, about $80 \mathrm{~km}$ (50 mi) west of the volcano. Photograph by Gerald Andrew (used with permission) between approximately 4:45 p.m. and 5:00 p.m. AST. AVO database image at URL: http:// www.avo.alaska.edu/image. .php?id=6020.

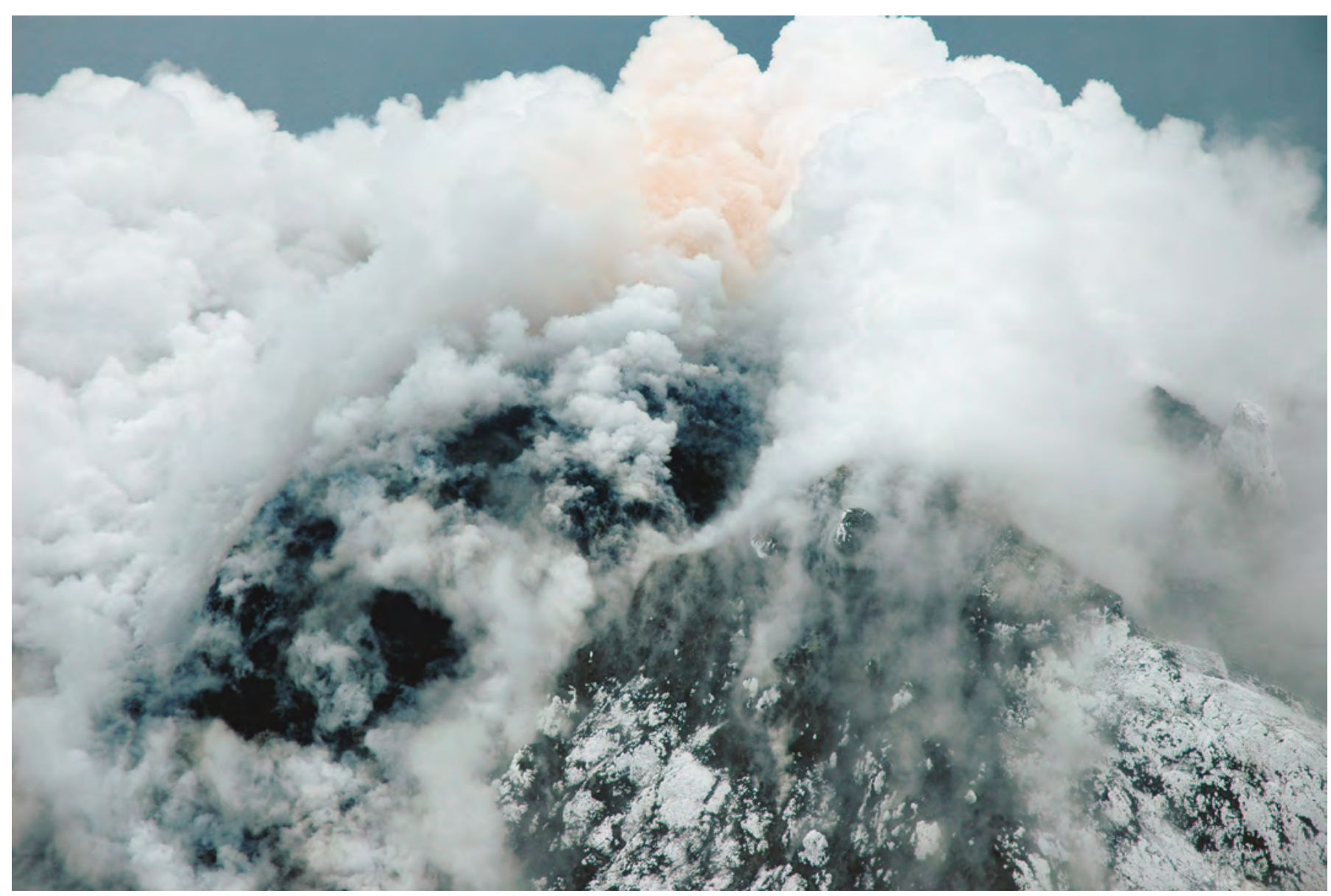

Figure 15. First sighting of new lava at the summit of Augustine Volcano, January 16, 2006. This aerial view shows the dark, ovoid new dome, about $180 \mathrm{~m}(590 \mathrm{ft})$ across, steaming and degassing profusely inside the summit crater. The new dome emerged from a vent that likely was excavated through the 1986 lava dome during the January 11-13 explosions. The yellow-orange color in steam probably indicates the presence of sulfur in the cloud (Mike Doukas, USGS, oral commun., 2006). Photograph by R.G. McGimsey, AVO/USGS. 
The eruption transitioned into a more continuous ash emission phase on January 28 (fig. 16). This phase was characterized by ash plumes generally lower than during the explosive phase, and the generation of more voluminous and pumiceous, high-silica andesite pyroclastic flows down the north flank of the volcano. Pumiceous pyroclastic flows and denser block and ash flows nearly reached the sea near Rocky Point on the north shore of the island (fig. 17). This phase of the eruption had the highest mass-flux rate of material based on mapped volumes of pyroclastic and effusive products (Michelle Coombs, USGS, written commun., 2006).

Beginning on February 2 or 3, effusive activity became dominant and a new lava dome began to fill much of the summit crater. Eventually, two lobes of blocky, low silicaandesite lava advanced north and northeast down the upper flank of the volcano (fig. 18). Intermittent spalling of debris from these flows produced a growing apron of block and ash avalanche deposits. A hiatus in effusive activity occurred between about February 10 and March 3 based on retrospective analyses of seismicity and morphologic changes at the summit (Michelle Coombs, USGS, oral commun., 2007). Effusion resumed in early March, with an especially vigorous period of lava effusion between March 8 and 14. "Drumbeat" seismic events, interpreted as signals related to the eruption of viscous lava (Iverson and others, 2006), also were occasionally recorded, especially during the vigorous effusion of mid-March. Seismicity associated with avalanching of hot debris from the two active lava-flow lobes extending north and northeast from the summit lava dome, was frequently recorded on the AVO network. A lightsensitive camera stationed on the coast near Homer (fig. 1) captured excellent imagery of the growing lava-flow lobes and associated avalanches. The more significant avalanches produced localized block and ash flows as well as limited ash plumes that rose less than $10,000 \mathrm{ft}$; mariners just offshore photographed one such avalanche on May 26 (fig. 19). Toward the waning portion of the eruption, the most active area for such gravitational collapse events was in a chute that headed on the northwest margin of the northern lava-flow lobe.

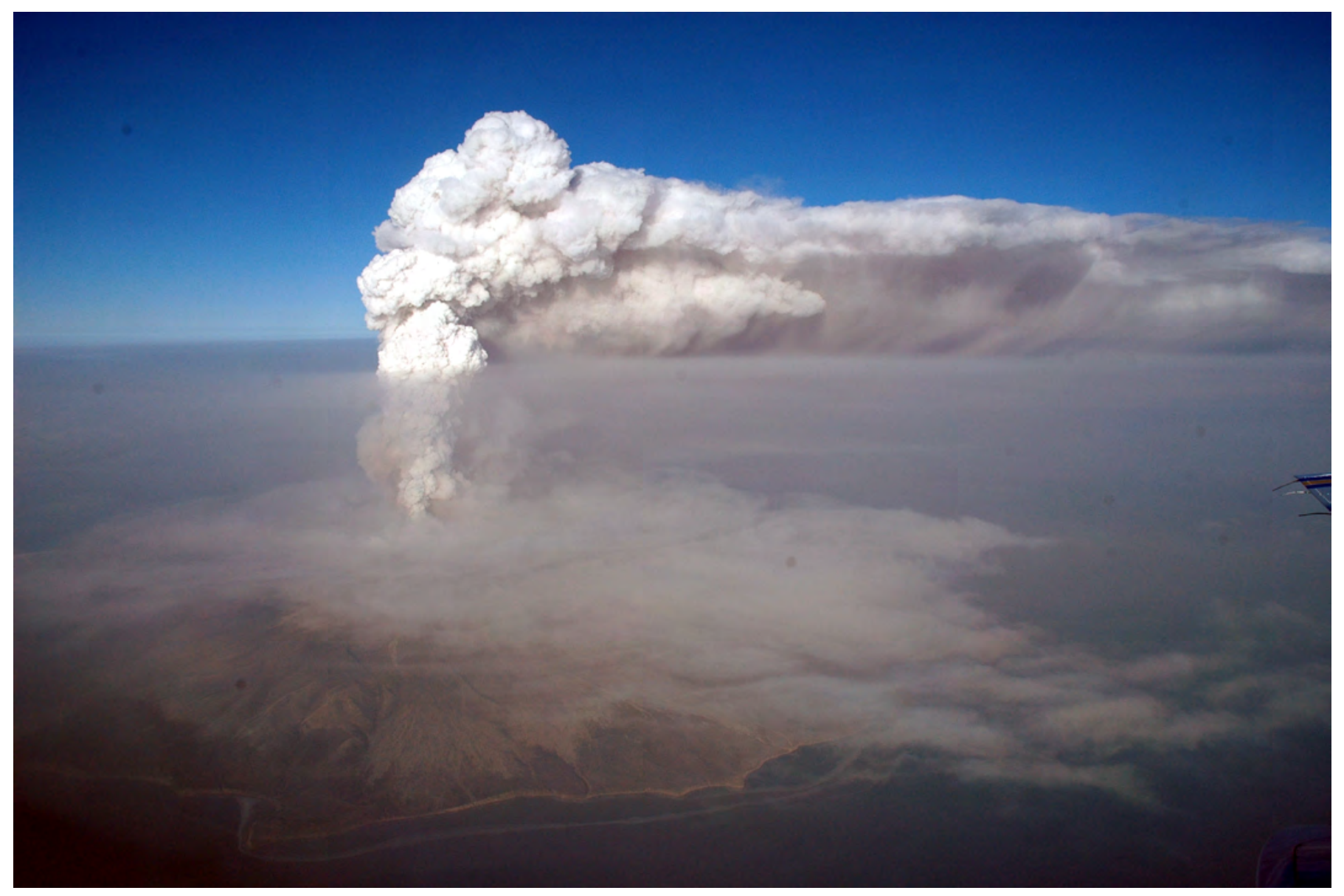

Figure 16. Steam and gas plume containing minor ash extending northeastward from Augustine Volcano during the continuous eruption phase of activity, January 30, 2006. Photograph by R.G. McGimsey, AVO/USGS. View from south-southeast. 


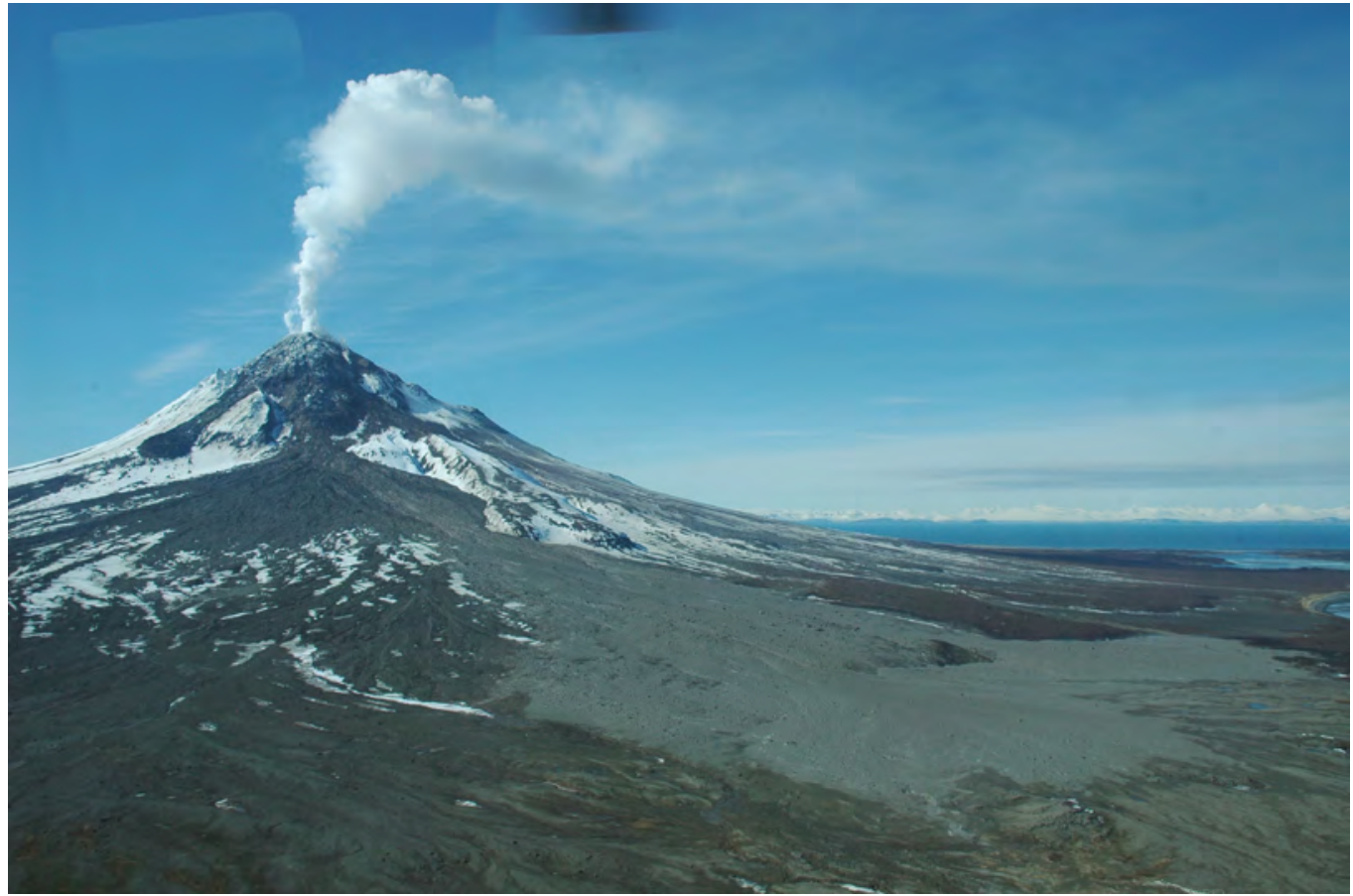

Figure 17A. View of the north flank of Augustine Volcano with a towering steam and gas plume rising from the 2006 lava dome at the summit, May 2006. The light-colored fan of material extending towards the lower right is the still-hot Rocky Point pyroclastic flow that was emplaced in late January 2006. Photograph by Kate Bull, AVO/ADGGS.

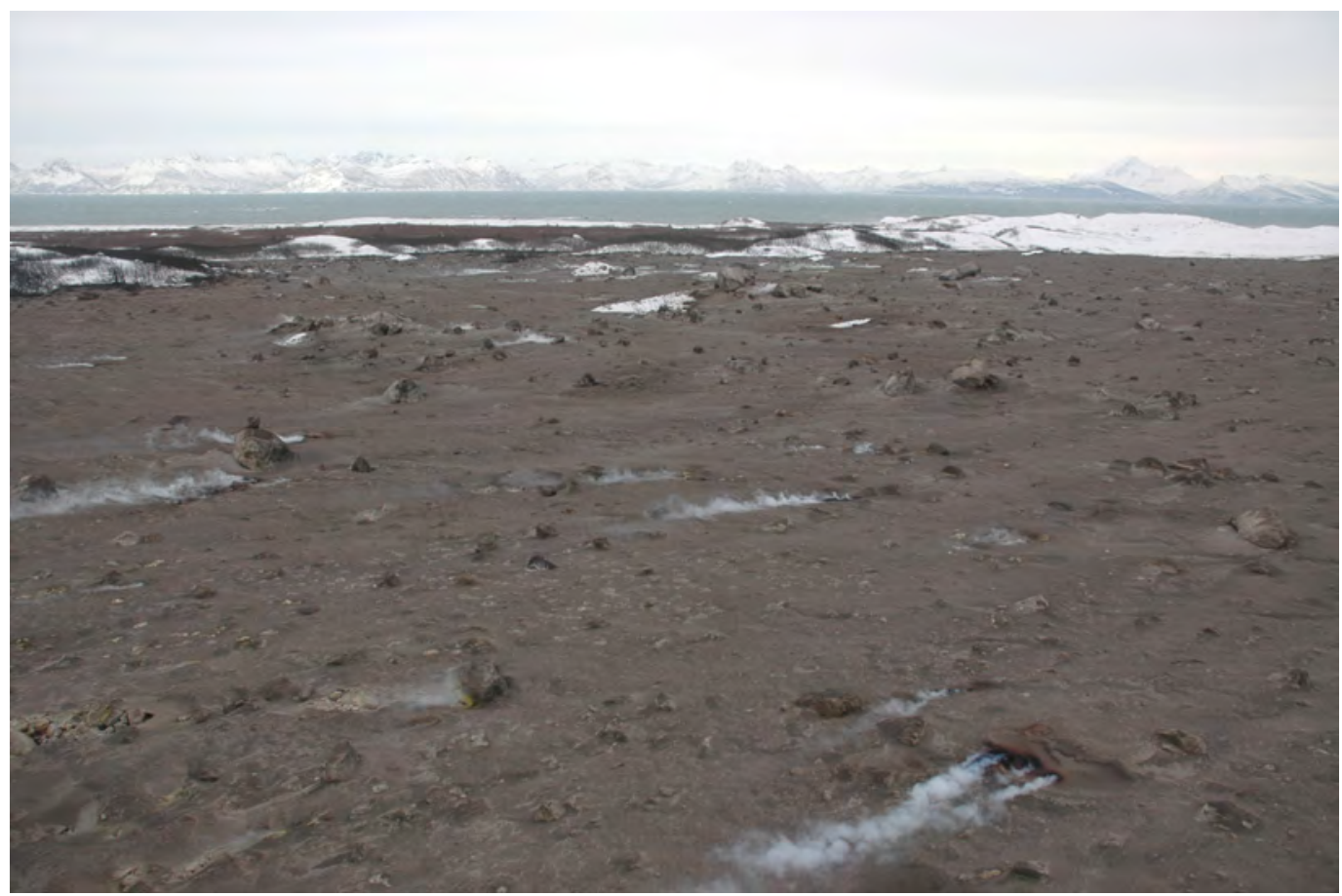

Figure 17B. Steaming blocks of dome rock on the surface of the Rocky Point pyroclastic flow fan on the north flank of Augustine Volcano, February 8, 2006. These flows were emplaced during the continuous phase of the eruption in late January. Hot lava blocks on the surface are up to several meters across. Photograph by Michelle Coombs, AVO/USGS. AVO database image at URL: http://www. avo.alaska.edu/image. $p h p ? i d=7536$. 


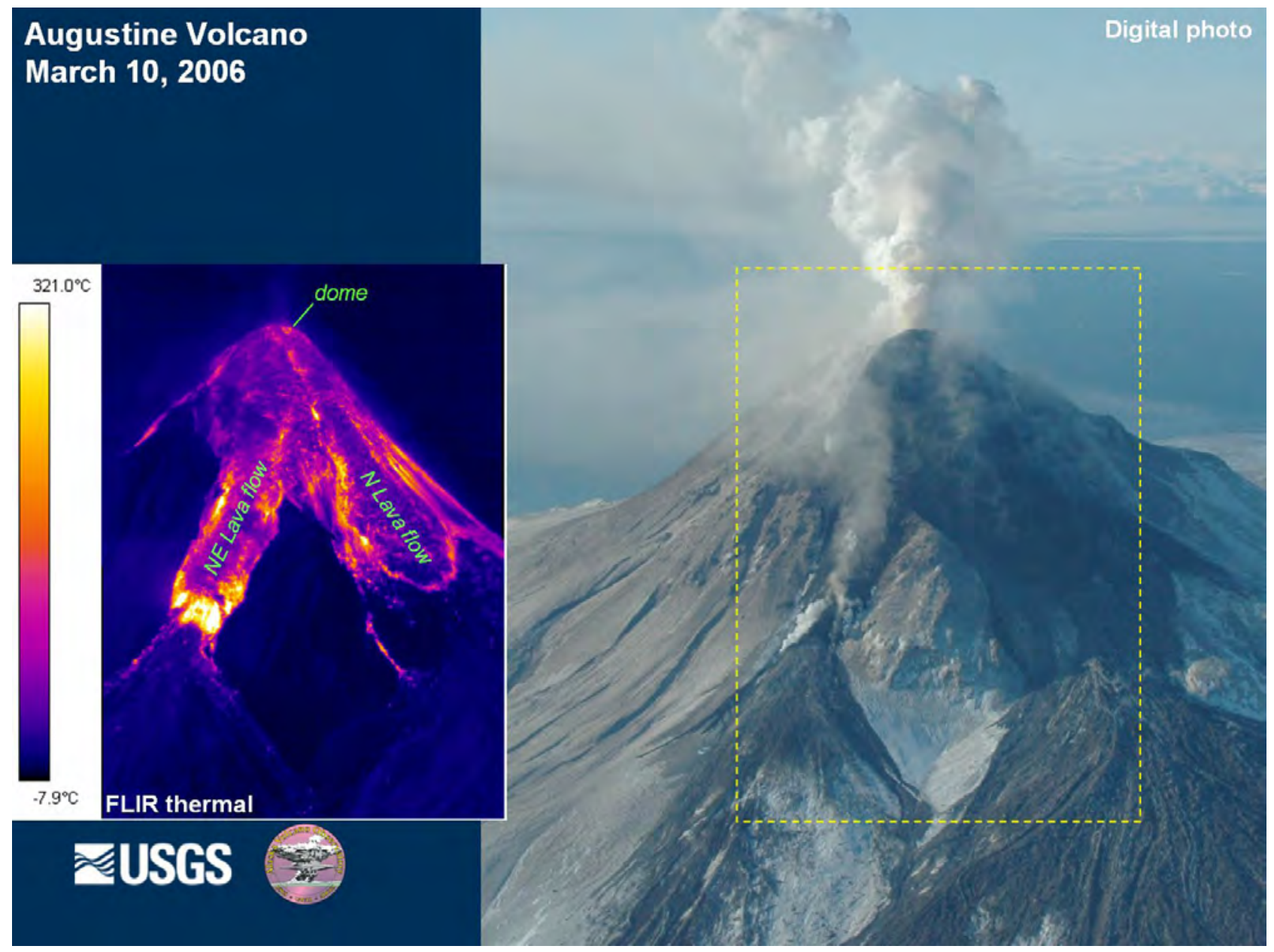

Figure 18. Forward Looking Infrared Radiometer (FLIR) and visual images of Augustine Volcano's north flank showing the active lava-flow lobes and summit lava dome. The thermal image also shows that the thicker northeast lava-flow lobe has hotter temperatures (some areas more than $1,000^{\circ} \mathrm{F}\left[540^{\circ} \mathrm{C}\right]$ ) in the toe while the thinner north lava flow edge is $\mathrm{cooler}\left(<600^{\circ} \mathrm{F}\right.$ $\left.\left[315^{\circ} \mathrm{C}\right]\right)$. FLIR image and photograph by R.L. Wessels, AVO/USGS, March 10, 2006, during vigorous extrusion of lava from the summit vent.

The eruption waned by the end of March; however, the exact date effusion ceased is uncertain. Through the end of 2006, Augustine Volcano produced little seismicity of significance with the exception of occasional rockfall and small avalanche signals which diminished in number over time. The lava dome and flows and pyroclastic flow fan to the north of the summit cooled slowly (figs. 20 and 21). Snowfall began to accumulate on many surfaces in October. Small lahars of fine-grained, oxidized, pinkish muddy material were produced during heavy rains in late summer and into the fall (Kate Bull, ADGGS, oral commun., 2006).

The final 2006 lava dome and flows contain an estimated $0.096 \mathrm{~km}^{3}$ of material. Combined with the preliminary figures for bulk eruptive volume of tephra-fall and -flow deposits (fig. 22), this results in an estimated 2005-06 bulk eruption volume of about 118 million cubic meters $\left(\sim 0.1 \mathrm{~km}^{3}\right.$; Coombs and others, 2006b) — about a third of the 1989-90 Redoubt eruptive volume (Gardner and others, 1994) and similar to the 1992 Mount Spurr/Crater Peak eruptive volume (Neal and others, 1995a). Previous eruptions at Augustine in 1986 and 1976 produced an estimated $0.264 \mathrm{~km}^{3}$ and $0.387 \mathrm{~km}^{3}$ of material (bulk volume) for comparison (Coombs and others, 2006b).

Juvenile material erupted during the 2005-06 activity at Augustine consisted of two end member compositions (lowsilica andesite and hi-silica andesite) and mixtures of the two; proportions of the end member compositions varied through the eruption and have been interpreted to reflect changes in the flux of new melt into the Augustine plumbing system and remobilization of melt left over from the 1976 and 1986 events (Coombs and others, 2006b). 


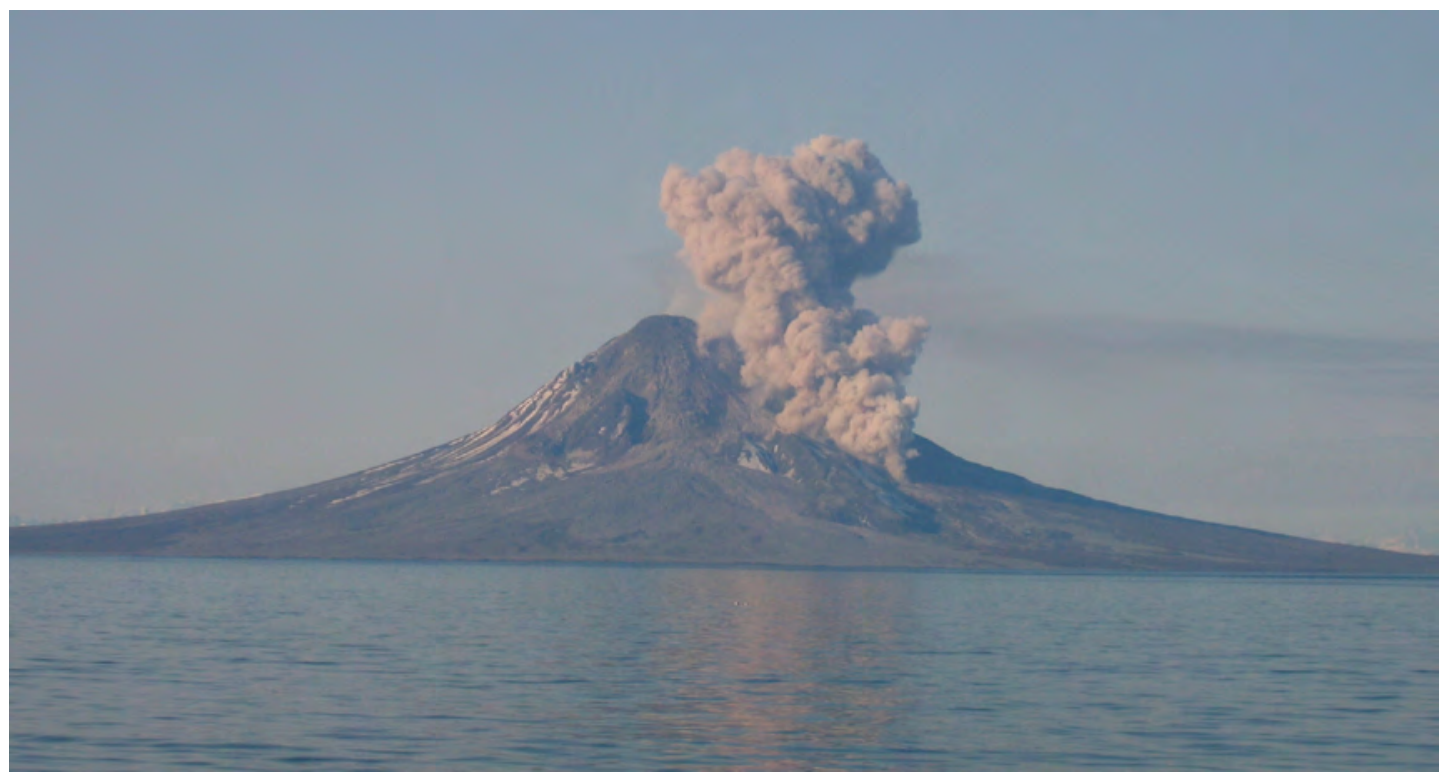

Figure 19. Spalling of hot rock from the front of the unstable northern lava flow created this block and ash avalanche and elutriate cloud as photographed from offshore about 8:00 a.m. ADT, May 26, 2006. Photograph courtesy Mike Byerly, Alaska Department of Fish and Game (ADFG; used with permission).

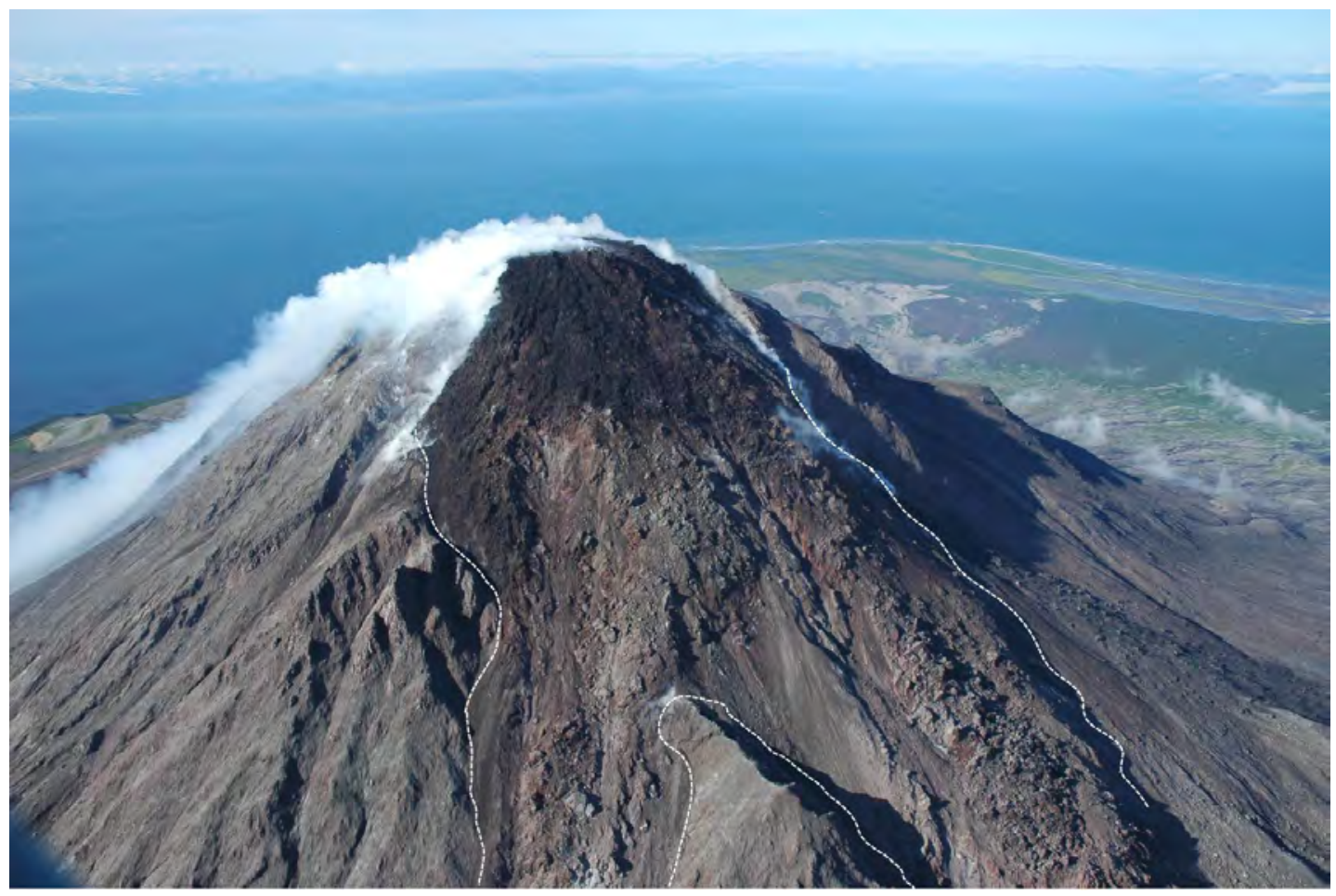

Figure 20. Oblique aerial view, towards the southwest, of the summit region of Augustine Volcano, August 7, 2006. The dark surface is the top of the new extrusive lava dome which transitions down the north slope into two prominent lava-flow lobes (white dotted lines; see fig. 22). Light colored interior of the lava flow at left has been exposed by spalling of lava blocks that formed a proximal apron of debris. The steep lava flow fronts of each lobe are not visible in this photograph, extending downslope out of the field of view. Photograph by Michelle Coombs, AVO/USGS. AVO database image at URL: http://www.avo.alaska. edu/image. php?id=11242. 


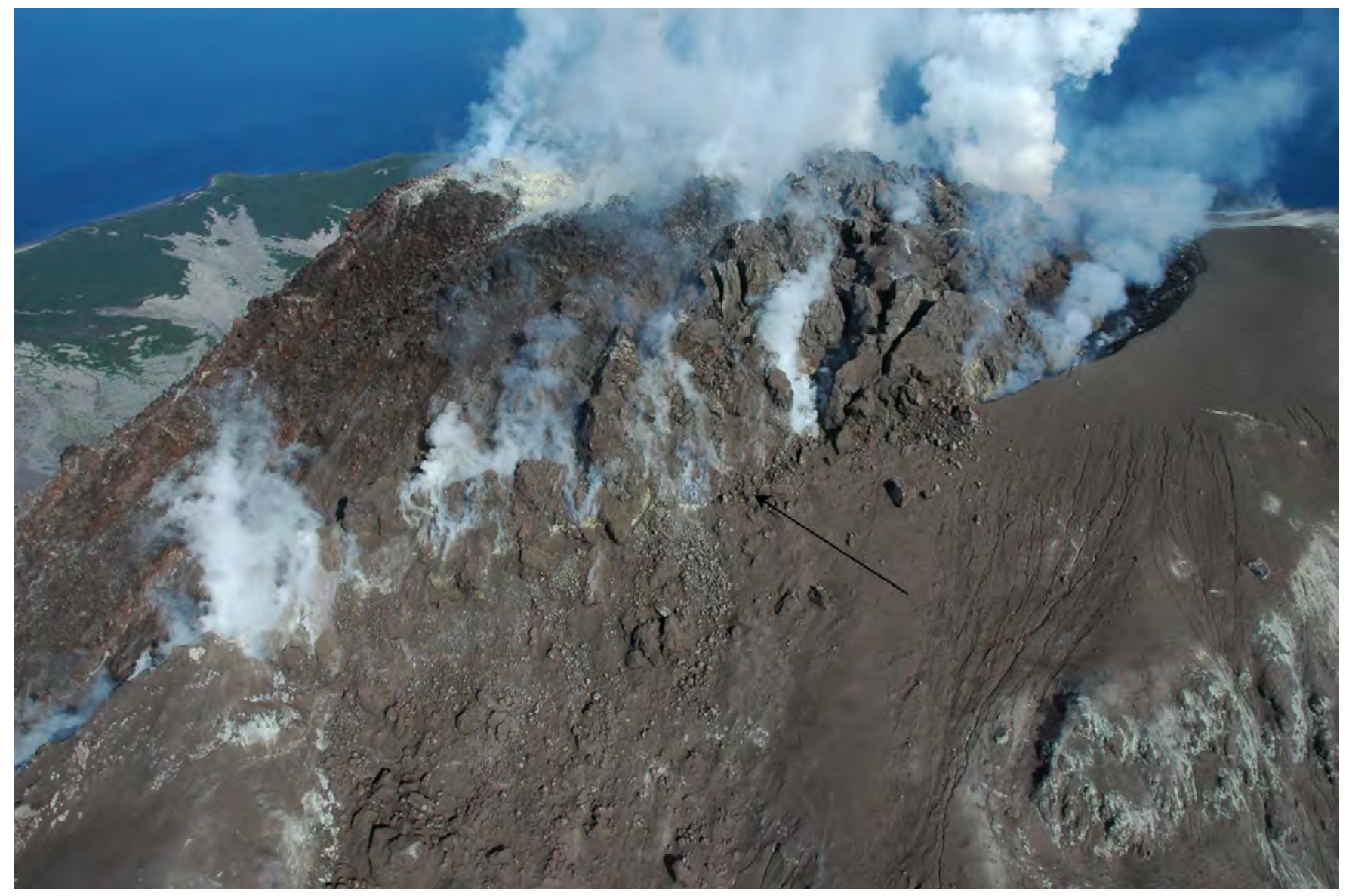

Figure 21. Aerial view of the 2006 lava dome and upper reaches of the lava-flow lobes showing the diversity of surface textures related to extrusion. Blocks of 2006 dome material have spilled over the western (nearest) rim of the remains of the pre-eruption summit crater rim (arrow). The smooth-looking surface at right is a coarse, proximal tephra blanket and raised rim formed during successive explosions in early 2006. Photograph by Michelle Coombs, AVO/USGS, August 6, 2006. AVO database image at URL: http://www.avo.alaska.edu/image.php?id=11297.

More than a dozen airborne-gas measurement flights were made during the eruption (McGee and others, 2006, 2008; Doukas and McGee, 2007). $\mathrm{SO}_{2}$ output ranged from 660 ton/d following the first significant phreatic eruptions in December 2005 to as high as 8,650 ton/d on March 1, 2006. Carbon dioxide measurements were made less frequently during the eruption, and ranged from about 5,000 to 6,000 ton/d during the mid-January activity to a high of 13,000 ton/d during the vigorous March extrusive pulse. Hydrogen sulfide measurements never exceeded the 8.2 ton/d measured on January 19. After effusion ceased, gas output for $\mathrm{CO}_{2}$ and $\mathrm{SO}_{2}$ steadily decreased but remained above pre-eruption levels through the last measurement of 2006 and into 2007.

The Augustine explosions in early 2006 interrupted air travel into and out of south-central Alaska on several days. One encounter between a jet and a distal, primarily volcanic- gas cloud required an inspection and cleaning. No damage occurred. A large turbine helicopter encountered the ash cloud over Cook Inlet resulting in minor damage. AVO received an ambiguous pilot report of a possible encounter with a largely gaseous cloud over southwest Alaska on January 30, but the details of this observation remain unverified. Schools, some businesses, and government offices were closed at least once during the eruption out of concern for potential ashfall on the Kenai Peninsula, and the communities of Kodiak, Iliamna, Homer, and other small communities in the Cook Inlet region experienced dustings of ash $(<1 \mathrm{~mm}$; Wallace and others, 2006). During the ramp up to explosive activity, citizens throughout southern Alaska stocked up on emergency supplies, air filters for automobiles, and dust masks.

A preliminary summary of the Augustine eruption chronology is listed in table 7 and the Level of Concern Color Code history for the Augustine eruption as reported by AVO 


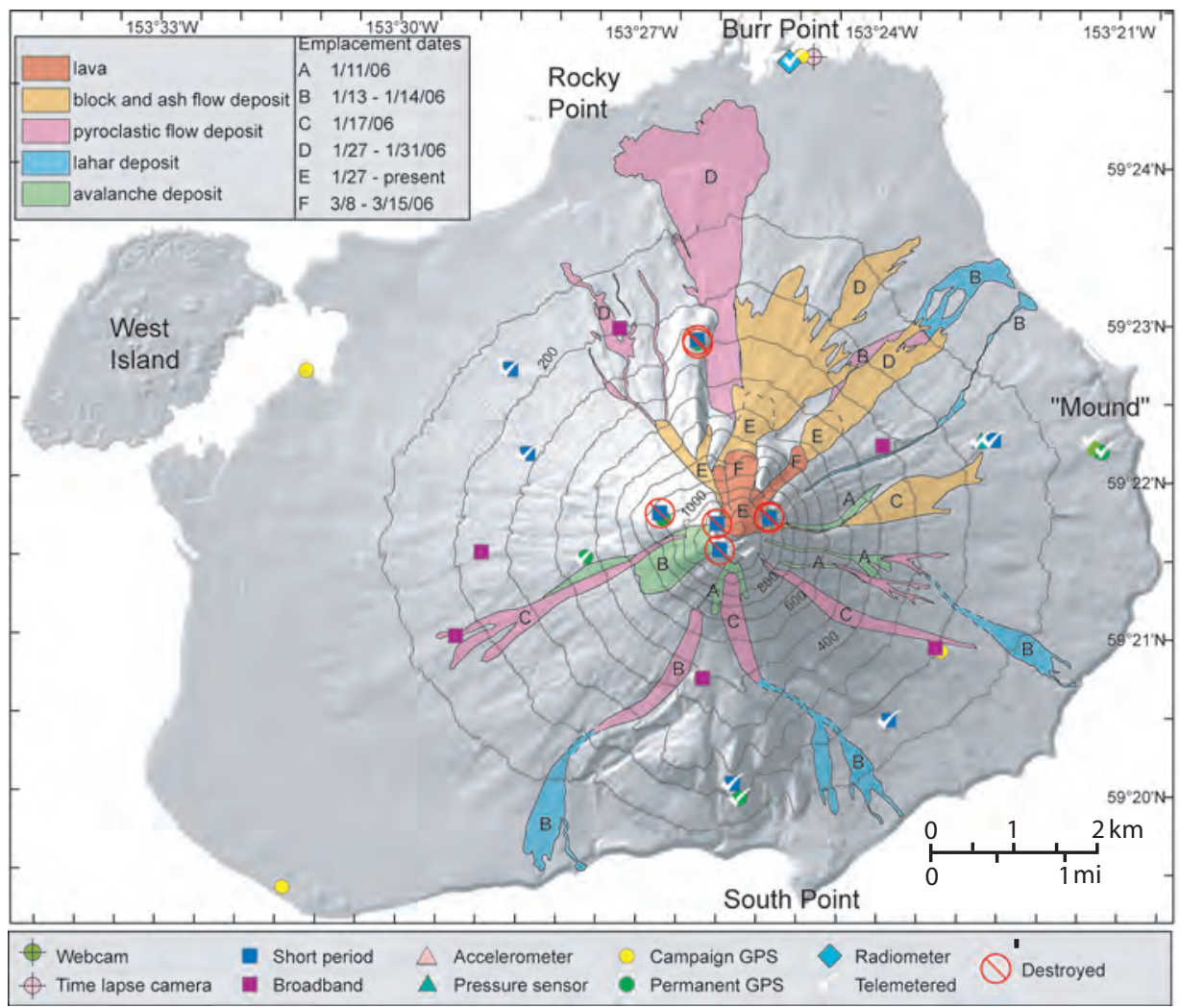

Modified from Power and others (2006)

Figure 22. Preliminary geologic map of products from the 2005-06 eruption of Augustine Volcano and location of primary geophysical and visual monitoring instrumentation sites. Figure courtesy M. Coombs, USGS.

is listed in table 3 . This eruption was the first major event near populated areas in Alaska since the Mount Spurr eruption in 1992 and demands for information were significant. To manage the scientific and hazard warning response to this eruption, AVO staff from Anchorage and Fairbanks, reinforced by colleagues from volcano observatories and other USGS offices from Hawaii, California, and Washington, operated a 24-hour crisis room from January 10 to May 19 (Adleman, 2006). The AVO Scientist in Charge established an eruption "Command Team" to assist in managing various aspects of the response from scientific and field coordination to media and hazard message management. AVO also employed a formal "Information Scientist" to assist with hazard information and press inquiries. AVO participated in an interagency press conference in December prior to the onset of significant explosive activity, and addressed likely eruption scenarios and hazards. AVO also arranged for a public interagency briefing and meeting in Homer, Alaska, in January to address concerns of the communities closest to the volcano.

AVO issued 84 information releases, 27 updates, and 222 status reports regarding Augustine activity to the public, media, airlines, and interagency cooperators in 2006 (Jennifer
Adleman, USGS, written commun., 2007). Each explosive event prompted call-downs according to interagency protocols (National Oceanic and Atmospheric Administration, 2004). Intense demand for up-to-date, web-based information prompted creation of an informal 'update box' on our web page where the duty scientist could post a brief statement regarding the most recent development (or lack of change).

AVO's scientific response to the eruption included deployment of additional monitoring equipment such as web cameras, time-lapse cameras, radiometers, pressure sensors, lightning-detection systems, broadband seismometers, and campaign GPS surveys. AVO staff conducted regular overflights for observations, photography, and airborne-gas surveys. Helicopter work included FLIR surveys, sampling, maintenance and deployment of additional instrumentation and fuel caches. A month-long field camp on the island in August supported a variety of field studies of deposits and impacts as well as work on the prehistoric geologic record and maintenance of damaged geophysical equipment. Together, the rich data sets from instrumental monitoring networks, remote sensing observations, and field and laboratory investigations are providing fodder for important studies of the eruption and the behavior of Augustine Volcano. 
Table 7. Preliminary chronology of major events and selected formal Alaska Volcano Observatory notifications pertaining to the 2005-06 unrest and eruption of Augustine Volcano, Alaska.

[Compiled from Alaska Volcano Observatory (AVO) web site archives, internal logs, and master AVO chronology spreadsheet designed by K. Wallace and maintained by many AVO staff members during and following the eruption. Times listed for Information Releases are formal time stamps on the header of Information Release documents; these times will differ slightly from those listed on our web page. Announcements of Color Code changes via our telephone call down system typically occur tens of minutes before official release of the Information Release via email, fax, and web posting. Plume height estimates came from a variety of sources (radar, satellite-derived cloud top temperatures, pilot reports) and were often obtained at different times by different methods during an individual event. Reconciling differences among the estimates, each of which have errors, is beyond the scope of this report. Time of explosions based on preliminary analysis by AVO seismologists. Universal time: (UT), Alaska daylight time (ADT) + 8 hours, Alaska standard time (AST) + 9 hours; *, next day in UT. Altitudes are above sea level. Shaded entries are key volcanic events. GPS, Global Positioning System; IR, Information Release; PIREP, pilot weather report; SIGMET, Significant Meteorologic Event; TFR, Temporary Flight Restriction; ft, foot; , approximately]

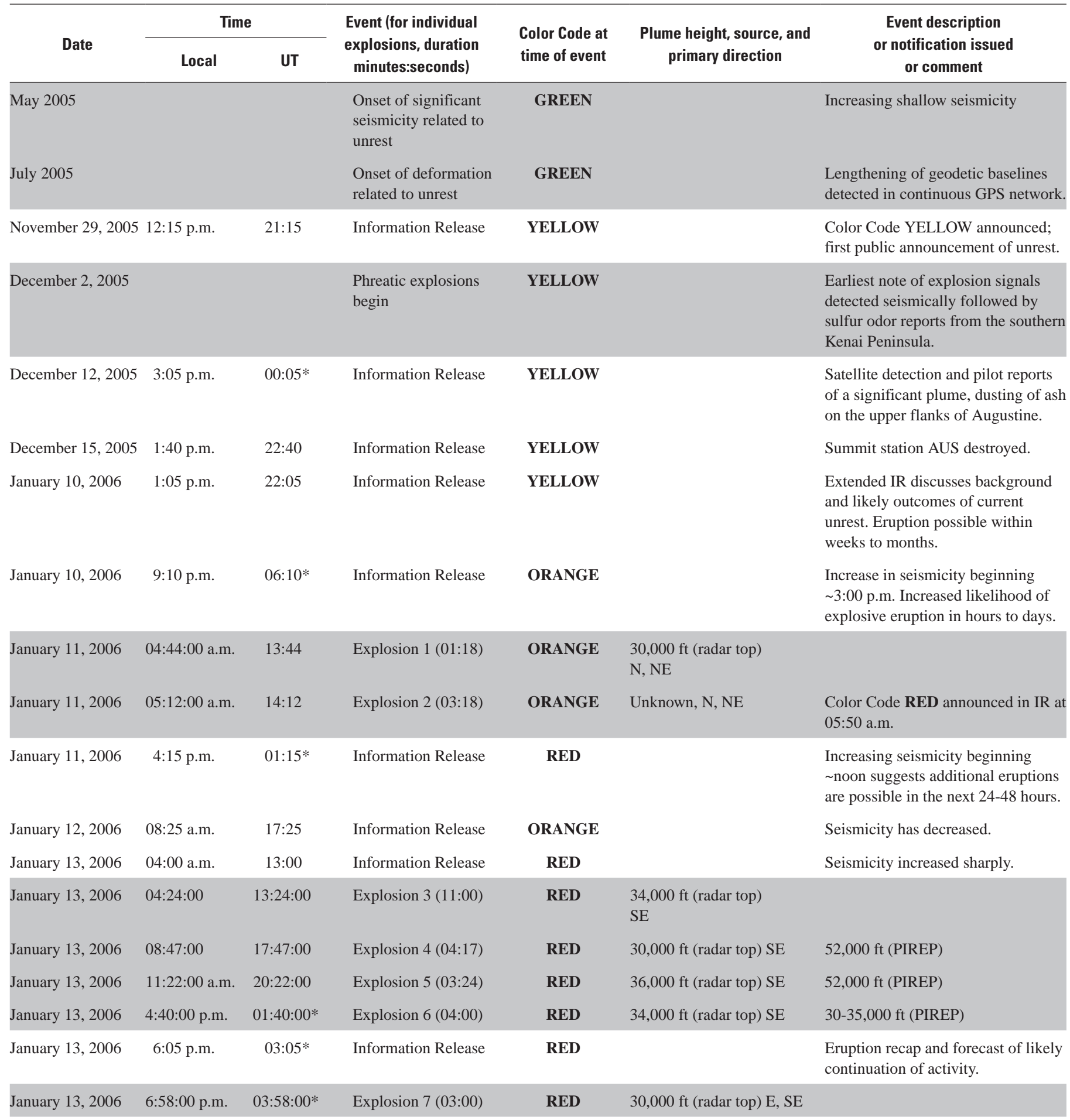


Table 7. Preliminary chronology of major events and selected formal Alaska Volcano Observatory notifications pertaining to the 2005-06 unrest and eruption of Augustine Volcano, Alaska.-Continued

[Compiled from Alaska Volcano Observatory (AVO) web site archives, internal logs, and master AVO chronology spreadsheet designed by K. Wallace and maintained by many AVO staff members during and following the eruption. Times listed for Information Releases are formal time stamps on the header of Information Release documents; these times will differ slightly from those listed on our web page. Announcements of Color Code changes via our telephone call down system typically occur tens of minutes before official release of the Information Release via email, fax, and web posting. Plume height estimates came from a variety of sources (radar, satellite-derived cloud top temperatures, pilot reports) and were often obtained at different times by different methods during an individual event. Reconciling differences among the estimates, each of which have errors, is beyond the scope of this report. Time of explosions based on preliminary analysis by AVO seismologists. Universal time: (UT), Alaska daylight time (ADT) + 8 hours, Alaska standard time (AST) + 9 hours; *, next day in UT. Altitudes are above sea level. Shaded entries are key volcanic events. GPS, Global Positioning System; IR, Information Release; PIREP, pilot weather report; SIGMET, Significant Meteorologic Event; TFR, Temporary Flight Restriction; ft, foot; , approximately]

\begin{tabular}{|c|c|c|c|c|c|c|}
\hline \multirow{2}{*}{ Date } & \multicolumn{2}{|c|}{ Time } & \multirow{2}{*}{$\begin{array}{l}\text { Event (for individual } \\
\text { explosions, duration } \\
\text { (minutes:seconds) }\end{array}$} & \multirow{2}{*}{$\begin{array}{l}\text { Color Code at } \\
\text { time of event }\end{array}$} & \multirow{2}{*}{$\begin{array}{l}\text { Plume height, source, and } \\
\text { primary direction }\end{array}$} & \multirow{2}{*}{$\begin{array}{c}\text { Event description } \\
\text { or notification issued } \\
\text { or comment }\end{array}$} \\
\hline & Local & UT & & & & \\
\hline January 14, 2006 & 0:14:00 & 09:14:00 & Explosion 8 (03:00) & RED & ? E, SE & \\
\hline January 14, 2006 & 08:40 a.m. & $17: 40$ & Information Release & RED & & $\begin{array}{l}\text { Eruption recap and forecast of } \\
\text { likelihood of continuing activity. }\end{array}$ \\
\hline January 14, 2006 & 4:15 p.m. & $01: 15^{*}$ & Information Release & RED & & $\begin{array}{l}\text { No change at volcano; PIREPS of } \\
\text { ash and sulfur smell over SE Alaska. }\end{array}$ \\
\hline January 15, 2006 & 09:45 a.m. & $18: 45$ & Information Release & ORANGE & & $\begin{array}{l}\text { Decreasing seismicity; additional } \\
\text { explosions could occur suddenly. }\end{array}$ \\
\hline January 16, 2006 & & & $\begin{array}{l}\text { First visual } \\
\text { observation of new } \\
\text { lava dome }\end{array}$ & ORANGE & & \\
\hline January 17, 2006 & 07:40 a.m. & $16: 40$ & Information Release & ORANGE & & $\begin{array}{l}\text { Seismicity up markedly in the last } \\
\text { hour; explosive eruption likely. }\end{array}$ \\
\hline January 17, 2006 & 07:58:00 & $16: 58$ & Explosion $9(04: 11)$ & ORANGE & $45,000 \mathrm{ft}$ (radar top), $\mathrm{NW}$ & 45,000ft (PIREP?) \\
\hline January 17, 2006 & 08:00 a.m. & $17: 00$ & Information Release & RED & & $\begin{array}{l}\text { Onset of Explosion } 9 \text { at } 07: 58 \text {; Color } \\
\text { Code changed. }\end{array}$ \\
\hline January 17, 2006 & 4:25 p.m. & $01: 25^{*}$ & Information Release & RED & & Recap of Explosion 9. \\
\hline January 18, 2006 & 09:05 a.m. & $18: 05$ & Information Release & ORANGE & & Decreased seismicity. \\
\hline January 26, 2006 & 4:50 p.m. & $01: 50^{*}$ & Information Release & ORANGE & & $\begin{array}{l}\text { Additional intervals of increased } \\
\text { seismicity during the day indicate } \\
\text { movement of magma. }\end{array}$ \\
\hline January 27, 2006 & $8: 24: 00$ p.m. & 05:24:00 & Explosion $10(09: 00)$ & ORANGE & $30,000 \mathrm{ft}$ (radar top), $\mathrm{SE}$ & \\
\hline January 27, 2006 & 08:35 p.m. & $05: 35^{*}$ & Information Release & RED & & Color Code RED announced. \\
\hline January 27, 2006 & 11:37:21 p.m. & $08: 37: 21 *$ & Explosion $11(01: 02)$ & RED & $<10,000 \mathrm{ft}$ (radar top), S, SE & \\
\hline January 28, 2006 & 02:04:13 a.m. & 11:04:13 & Explosion 12 (02:06) & RED & $26,000 \mathrm{ft}$ (radar top), S, SE & \\
\hline January 28, 2006 & 07:42:00 a.m. & $16: 42: 00$ & Explosion $13(03: 00)$ & RED & $25,000 \mathrm{ft}$ (radar top) S, SE & 35,000 ft (PIREP) \\
\hline January 28, 2006 & 08:45 a.m. & $17: 45$ & Information Release & RED & & $\begin{array}{l}\text { Recap of four explosions in the last } \\
12 \text { hours and ash cloud information. } \\
\text { Further explosions may occur. }\end{array}$ \\
\hline January 28, 2006 & 2:30 p.m. & $22: 30$ & $\begin{array}{l}\text { Continuous ash } \\
\text { emission begins }\end{array}$ & RED & & \\
\hline January 29, 2006 & 6:30 p.m. & $03: 30 *$ & Information Release & RED & $\begin{array}{l}\text { Up to } 30,000 \mathrm{ft} \text { (radar, } \\
\text { satellite, observation flight) } \\
\text { WSW, S }\end{array}$ & $\begin{array}{l}\text { Ash emission continues, pyroclastic } \\
\text { flows, ash clouds. }\end{array}$ \\
\hline January 30, 2006 & 09:15 a.m. & $18: 15$ & Information Release & RED & Up to $25,000 \mathrm{ft}$ (radar) & $\begin{array}{l}\text { Three strong seismic events within } \\
\text { continuous ash emission signal. }\end{array}$ \\
\hline January 30, 2006 & 4:55 p.m. & $01: 55^{*}$ & Information Release & RED & $\begin{array}{l}16,000 \mathrm{ft} \text { (satellite and } \\
\text { observation flight) } \mathrm{N}\end{array}$ & Ash emission continues. \\
\hline
\end{tabular}


Table 7. Preliminary chronology of major events and selected formal Alaska Volcano Observatory notifications pertaining to the 2005-06 unrest and eruption of Augustine Volcano, Alaska.-Continued

[Compiled from Alaska Volcano Observatory (AVO) web site archives, internal logs, and master AVO chronology spreadsheet designed by K. Wallace and maintained by many AVO staff members during and following the eruption. Times listed for Information Releases are formal time stamps on the header of Information Release documents; these times will differ slightly from those listed on our web page. Announcements of Color Code changes via our telephone call down system typically occur tens of minutes before official release of the Information Release via email, fax, and web posting. Plume height estimates came from a variety of sources (radar, satellite-derived cloud top temperatures, pilot reports) and were often obtained at different times by different methods during an individual event. Reconciling differences among the estimates, each of which have errors, is beyond the scope of this report. Time of explosions based on preliminary analysis by AVO seismologists. Universal time: (UT), Alaska daylight time (ADT) +8 hours, Alaska standard time (AST) +9 hours; *, next day in UT. Altitudes are above sea level. Shaded entries are key volcanic events. GPS, Global Positioning System; IR, Information Release; PIREP, pilot weather report; SIGMET, Significant Meteorologic Event; TFR, Temporary Flight Restriction; ft, foot; , approximately]

\begin{tabular}{|c|c|c|c|c|c|c|}
\hline Date & \multicolumn{2}{|c|}{ Time } & $\begin{array}{l}\text { Event (for individual } \\
\text { explosions, duration } \\
\text { (minutes:seconds) }\end{array}$ & $\begin{array}{l}\text { Color Code at } \\
\text { time of event }\end{array}$ & $\begin{array}{l}\text { Plume height, source, and } \\
\text { primary direction }\end{array}$ & $\begin{array}{l}\text { Event description } \\
\text { or notification issued } \\
\text { or comment }\end{array}$ \\
\hline January 31, 2006 & 6:00 p.m. & 03:00* & Information Release & RED & Up to $15,000 \mathrm{ft}$ (radar) $\mathrm{N}$ & $\begin{array}{l}\text { Recap of continuous activity; } \\
\text { discrete explosion frequency } \\
\text { diminishing. }\end{array}$ \\
\hline February 1, 2006 & 9:45 a.m. & $18: 45$ & Information Release & ORANGE & & $\begin{array}{l}\text { Color Code ORANGE announced; } \\
\text { decreasing height of ash clouds. } \\
\text { Continuous ash production, } \\
\text { pyroclastic flows, continue. }\end{array}$ \\
\hline February 2, 2006 & & & $\begin{array}{l}\text { Seismicity reflecting } \\
\text { effusion and block } \\
\text { and ash flows begins }\end{array}$ & ORANGE & & \\
\hline April 28, 2006 & 09:45 a.m. & $17: 45$ & Information Release & YELLOW & & $\begin{array}{l}\text { Color Code YELLOW announced; } \\
\text { dome and lava flow activity ceased. }\end{array}$ \\
\hline May 19, 2006 & 9:10 a.m. & $17: 10$ & Information Release & YELLOW & & AVO ends $24 / 7$ staffing. \\
\hline August 9, 2006 & 3:00 p.m. & 23:00 & Information Release & GREEN & & Color Code GREEN announced. \\
\hline
\end{tabular}

The protracted eruption also exercised the warning systems of AVO and other Federal and State agencies. Mariners were warned of ash fall and the possibility of floating volcanic debris near the island. The National Weather Service (NWS) issued numerous SIGMETs, Volcanic Ash Advisories (VAAs), Ashfall Advisories, and other public special weather statements. The Federal Aviation Administration (FAA) maintained a temporary flight restriction around Augustine from December 13, 2005, through April 28, 2006. State and municipal health agencies issued air-quality alerts and public reminders of ash fall preparedness on numerous occasions. Despite the many explosive events and ash clouds, no significant ash fell on any community, reflecting the relatively small volume and short duration of individual explosions.
Augustine Volcano is frequently active, close to populated areas and is one of the most visible and accessible of volcanoes in south-central Alaska. As such, it was extremely well monitored by instrumentation prior to the onset of unrest (Power and others, 2006). The volcano forms the bulk of Augustine Island, an $8 \times 11 \mathrm{~km}(5 \times 7 \mathrm{mi})$ island in lower Cook Inlet; uplifted Jurassic and Cretaceous sediments are exposed on the south side of the island. Augustine is a conical, central dome and lava flow complex surrounded by a more gently sloping apron of fragmental deposits. Its pre-eruption height was $1,260 \mathrm{~m}(4,134-\mathrm{ft})$ and we have yet to determine the exact change to summit elevation following the 2006 activity. Repeated sector collapses during the late Holocene have produced debris avalanches into Cook Inlet (Beget and Kienle, 1992). Previous historical eruptions include significant activity in 1883, 1835, 1963-64, 1976, and 1986. 


\section{Fourpeaked Volcano}

CAVW\# 1102-26

$58^{\circ} 46^{\prime} \mathrm{N} 153^{\circ} 40^{\prime} \mathrm{W}$

$2,104 \mathrm{~m}(6,903 \mathrm{ft})$

Cook Inlet/Alaska Peninsula

PHREATIC ERUPTION AND VIGOROUS VOLCANIC DEGASSING

As fall arrived in Alaska, a phreatic eruption from a volcano not considered active in the Holocene surprised AVO and residents of south-central Alaska. Late on Sunday, September 17, AVO received several citizen telephone reports of a dark plume, fed by what appeared to be two sources, rising from the area near Cape Douglas in lower Cook Inlet (fig. 23). Satellite analysis indicated the source of the plumes to be roughly between closely spaced Douglas and Fourpeaked volcanoes (fig. 24). The drifting cloud produced by these rising plumes persisted throughout the night, reaching a minimum altitude of $20,000 \mathrm{ft}(6,100 \mathrm{~m}$ based on radar data; Dave Schneider, USGS, written commun., 2006), but drifting only $20 \mathrm{~km}$ (12 mi) downwind in an unusually calm and clear atmosphere over south-central Alaska.
The next day, AVO issued an information release mentioning Douglas and Fourpeaked volcanoes, but stated that the exact nature and source of the plumes remained unclear. Neither volcano was monitored seismically, and data from the nearest stations at Katmai and Augustine initially showed nothing dramatic. Deteriorating weather conditions precluded visual observations, but an overflight was scheduled for the first clear window. On the afternoon of September 18, NWS relayed a pilot report of a strong sulfur odor $300 \mathrm{~km}$ (190 mi) northwest of Fourpeaked. This was an area likely to be impacted by drift of the September 17 cloud according to PUFF, a volcanic ash tracking model used by AVO (Searcy and others, 1998). Pilots in the Lake Iliamna area (fig. 24) on the morning of September 18 also reported a strong sulfur odor, a locality also consistent with likely cloud drift on the 17 th.

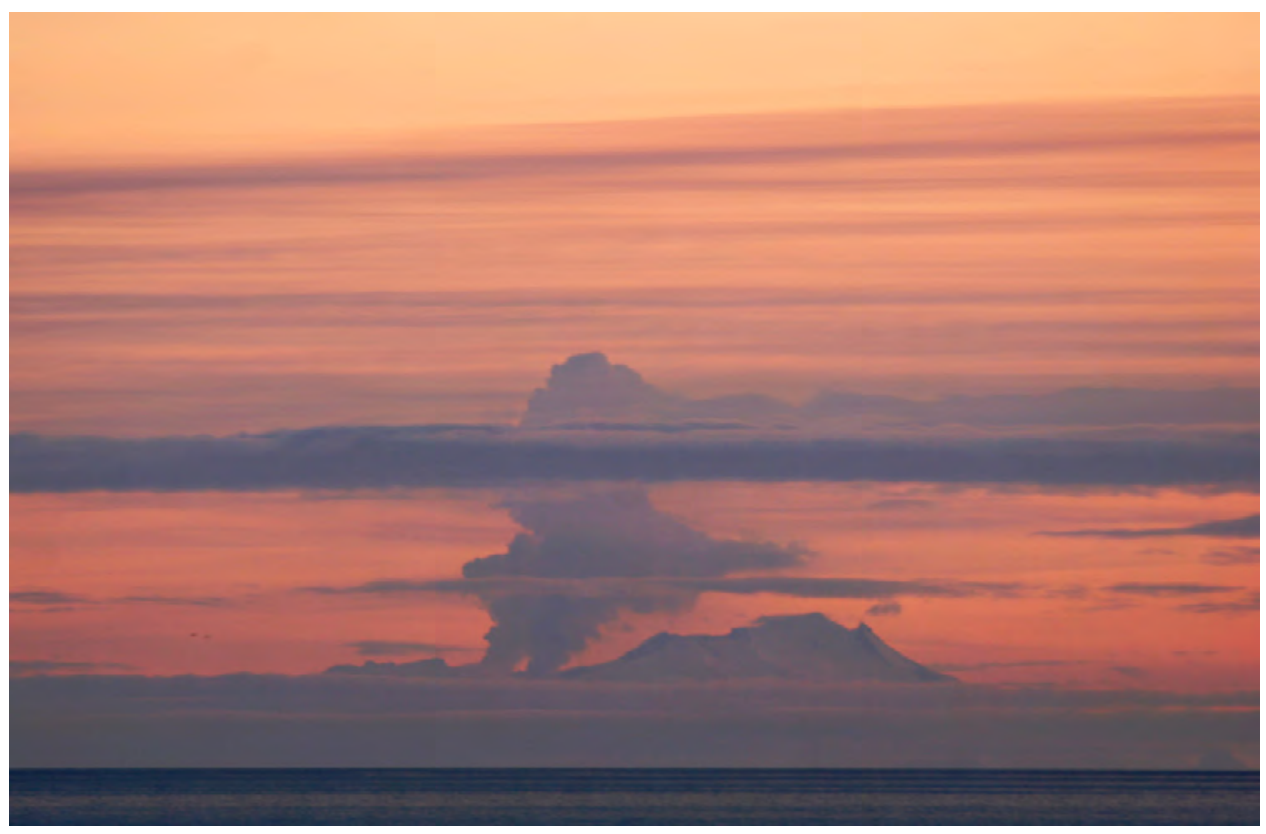

Figure 23. Eruptive plume rising above Fourpeaked volcano on September 17, 2006. Photograph taken from Main Street in Homer, Alaska, by Lanny Simpson (used with permission), Alaska High Mountain Images. 


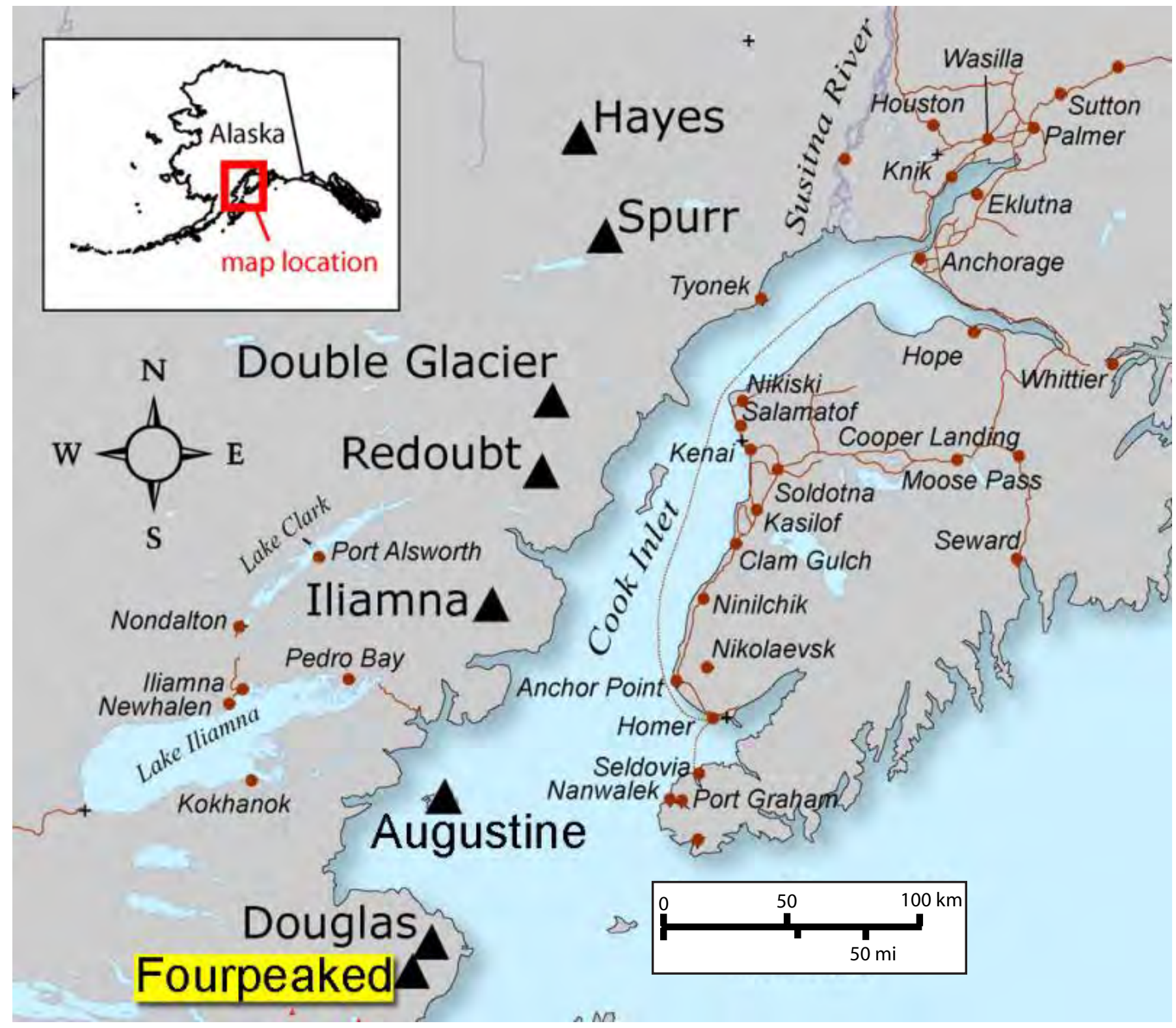

Figure 24. Cook Inlet showing the location of Fourpeaked volcano (highlighted). Map courtesy of J. Schaefer, ADGGS. AVO database image at URL: http://www.avo.alaska.edu/image.php?id=11084.

On September 20, AVO received NWS radar and other satellite data indicating particulate and sulfur-bearing properties in the cloud of September 17, confirming a volcanic source for the event. Based on this, AVO announced Level of Concern Color Code YELLOW for both Douglas and Fourpeaked volcanoes because the source was still uncertain. NEXRAD Doppler radar images from King Salmon (fig. 1) showed a particulate cloud in the atmosphere from at least 12:00 p.m. to 9:45 p.m. ADT on September 17 (fig. 25). The cloud appeared most energetic (dense) in the first 2 hours (Dave Schneider, USGS written commun., 2006). The bulk of the cloud remained over the point of origin for much of this time, reflecting very calm atmospheric conditions on that day. In addition, Ozone Monitoring Equipment onboard National Aeronautics and Space Administration's (NASA) Aura satellite indicated a pod of $\mathrm{SO}_{2}$ gas in the general vicinity of the eruption plume at 3:00 p.m. ADT (fig. 26). Subsequently, AVO received reports of a very fine-ash dusting at Nonvianuk Lake outlet (fig. 26; $110 \mathrm{~km}$ or $70 \mathrm{mi}$ west northwest of Fourpeaked) and near Homer (fig. 26; $150 \mathrm{~km}$ or 90 mi northeast of Fourpeaked; fig. 24). The Nonvianuk report stated, "We have a heavy sulfuric smell in the air and ash 


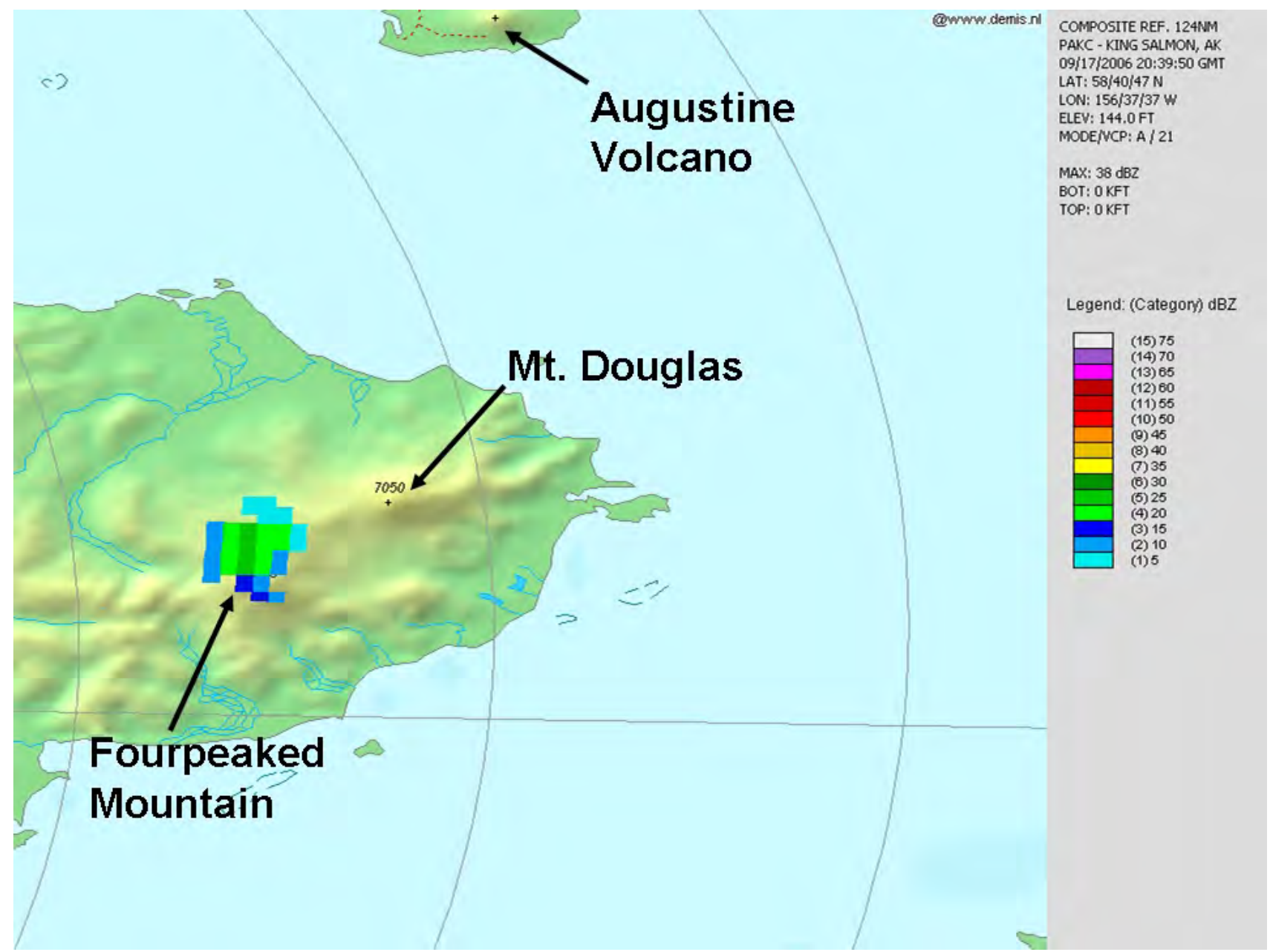

Figure 25. Radar data for the September 17 plume from Fourpeaked volcano. These data were collected by the National Weather Service King Salmon NEXRAD weather radar at 12:40 p.m. ADT (20:40 UTC). The color scheme shows a scale of radar reflectivity from light blue (low) to dark green (moderate). Figure courtesy of D. Schneider, AVO/USGS.

filling the air. The wind here is blowing from the ESE..." No samples were retrievable from either location for analysis, but the Nonvianuk report is consistent with PUFF trajectories for a cloud reaching about $20,000 \mathrm{ft}(6,100 \mathrm{~m})$ on the afternoon of September 17. Interestingly, multi-spectral satellite images showed no ash signature in the plume on September 17, but AVO analysts did note a thermal anomaly in the vicinity of Fourpeaked (J. Dehn, University of Alaska Fairbanks Geophysical Institute (UAFGI), written commun., 2006). Following the initial event on September 17th, no further particulate clouds were imaged by radar or other means.

An AVO overflight on September 20 confirmed Fourpeaked as the source of volcanic activity. Despite cloud cover of the actual summit, observers in a fixed-wing aircraft circled several distinct vapor clouds rising through the cloud deck above Fourpeaked. Visible patches of discolored snow and ice, especially north and west of the Fourpeaked summit, suggested ash fallout. An AVO helicopter crew later on the same day photographed a lobate, dark debris-flow tongue that had emerged from glacial ice about 3,000 ft (900 m) below the cloud-covered Fourpeaked summit (fig. 27); patchy areas of grey ash on the glacial ice around the summit and to the northeast also were noted. Clouds and fuel limitations prevented any further exploration of the area.

Aerial inspection of the Fourpeaked area on September 23 finally revealed the source of the September 17 plume and continuing fumarolic emissions. Water vapor and volcanic gas billowed from a dramatic, linear series of pits or vents extending about $1,250 \mathrm{~m}(4,100 \mathrm{ft})$ across the heavily crevassed and disrupted glacial-ice cover on the north side of the summit region (figs. 28 and 29). Multiple sources of vapor from these vents explain the apparent double plume seen in 


\section{Aura/OMI - 09/17/2006 00:40-23:02 UT - Orbit 11573}

$\mathrm{SO}_{2}$ mass: $0.271 \mathrm{kt}$; Area: $3746 \mathrm{~km}^{2} ; \mathrm{SO}_{2}$ max: $6.52 \mathrm{DU}$ at lon: -153.41 lat: 58.95

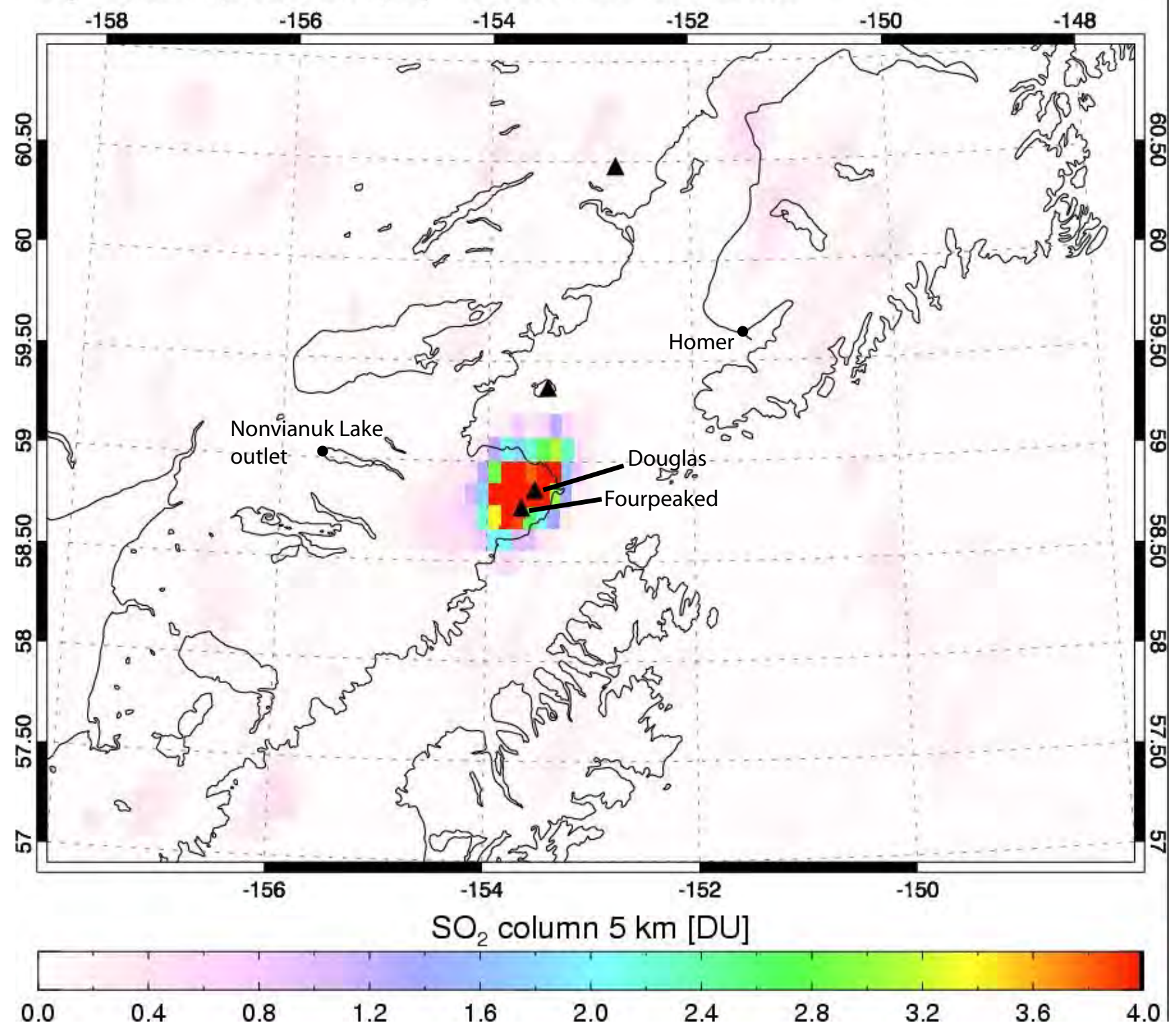

Figure 26. Sulfur-dioxide cloud detected on September 17, 2006, by the OMI sensor. Colors represent sulphur-dioxide concentration in Dobson Units (DU). Figure courtesy of S. Carn, Volcanic Emissions Group at University of Maryland Baltimore County.

the photograph of September 17 (fig. 23). A light dusting of dark material surrounded some of the open pits (fig. 28), and several elongate dark stripes leading down slope from at least one vent probably represented remobilized fragmental ejecta mixed with melted ice and snow (or plume condensate). A subtle series of snow-mantled rills leading down slope in the same area (fig. 29) indicated several episodes of surface debris or water flow. Stormy weather between September 17-23, produced new snowfall indicating that the ejecta collars and small debris flows observed on September 23 had occurred after the initial event (figs. 28 and 29). 


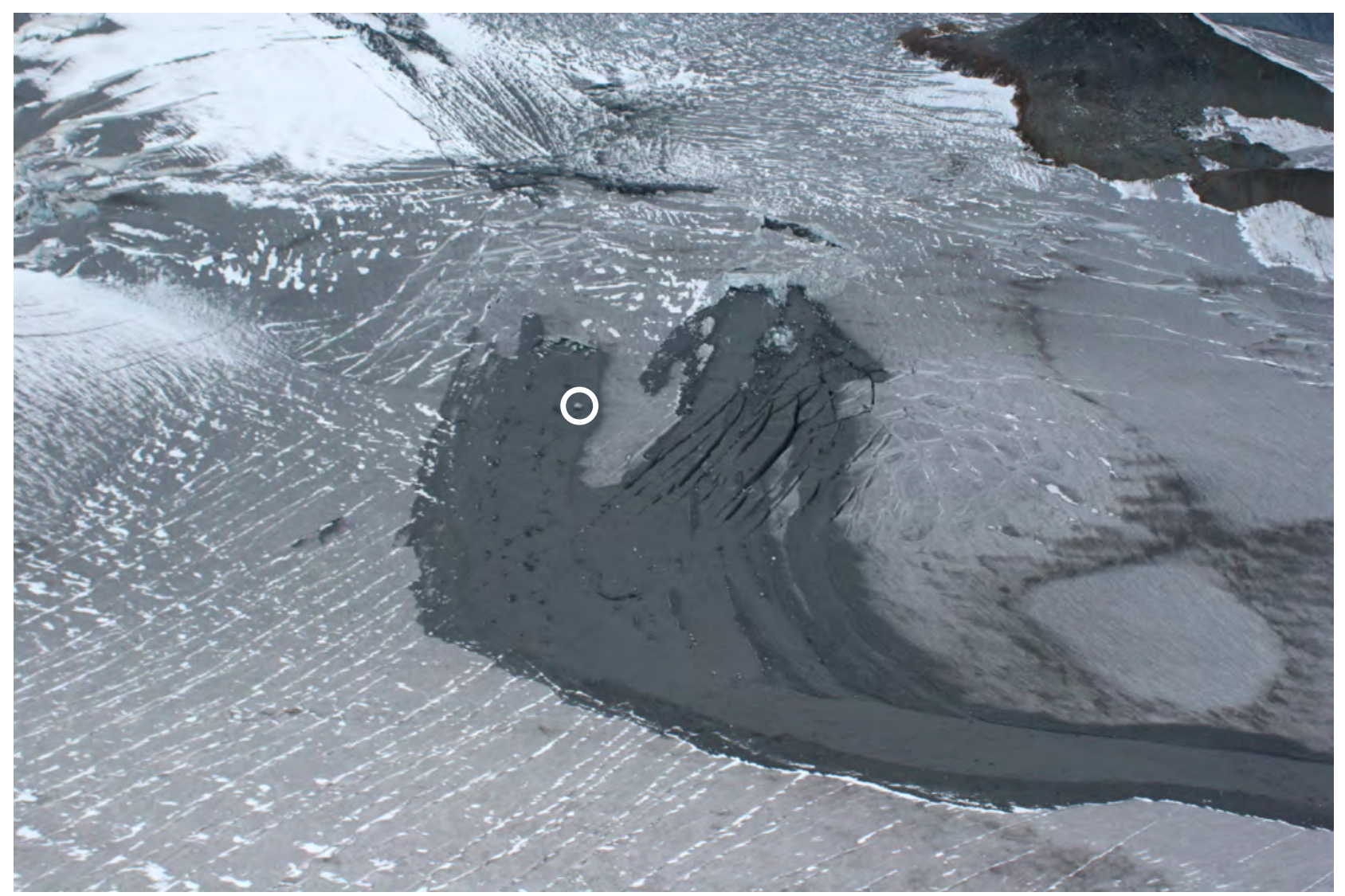

Figure 27. Dark, muddy debris flow that exited cracks in glacial ice about $4 \mathrm{~km}(2.5 \mathrm{mi})$ north of Fourpeaked summit on September 17, 2006. Flow direction is towards the lower right. Width of debris flow where two separate lobes merge about $250 \mathrm{~m}$ (820 ft). Note prominent block of rafted ice about $5 \mathrm{~m}(16 \mathrm{ft}$ ) across (circled). This debris flow was the first evidence that the event of September 17 included an outburst-flood component. Note lighter gray fine-ash mantle on most of the glacier surface around the debris flow. Areas of bare ice and snow may have been stripped by high winds or rain during bad weather between September 17 and 20. Photograph by G. Tygat, UAFGI, September 20, 2006. AVO database image at URL: http://www.avo.alaska.edu/image.php?id=11163.

AVO scientists visited the area by helicopter on September 24 and 25. The vent area consisted of as many as nine discrete craters or pits, and between three and five were venting steam and volcanic gas at any one time. The vents occurred along a line trending north from the summit basin, inferred to be a glacial cirque, obliquely down-slope across a northwest trending, ice-covered ridge. The bottoms of nonsteaming pits were covered with blocks of debris-mantled ice (fig. 30). The upper craters within the Fourpeaked summit cirque had coalesced creating a heavily disrupted ice zone. Most craters were surrounded by fine (?) debris collars that did not extend very far from their rims; there was no evidence of additional, significant ash emission since September 17. FLIR imaging of the pits indicated elevated temperatures as high as $75^{\circ} \mathrm{C}\left(167^{\circ} \mathrm{F}\right)$; however, these values are minimums due to steam obscuration. A strong sulfur odor was noted downwind of the vents as far as $50 \mathrm{~km}(30 \mathrm{mi})$.

The glacial outburst associated with the September 17 event originated from beneath a chaotic ice jumble on the unnamed north-trending glacier at an elevation of about 5,000 $\mathrm{ft}$. This flood apparently scoured a steep-walled canyon more than $100 \mathrm{~m}$ (330 ft) deep in places (figs. 31, 32, and $\underline{33}$ ). Blocks of ice up to $5 \mathrm{~m}$ (16 ft) or more across had been rafted in a mixture of water and fine-grained to cobble-boulder sized, heterolithologic volcanic debris (fig. 34) at least $6 \mathrm{~km}$ (4 mi) down slope, where material spilled off the front of the glacier 


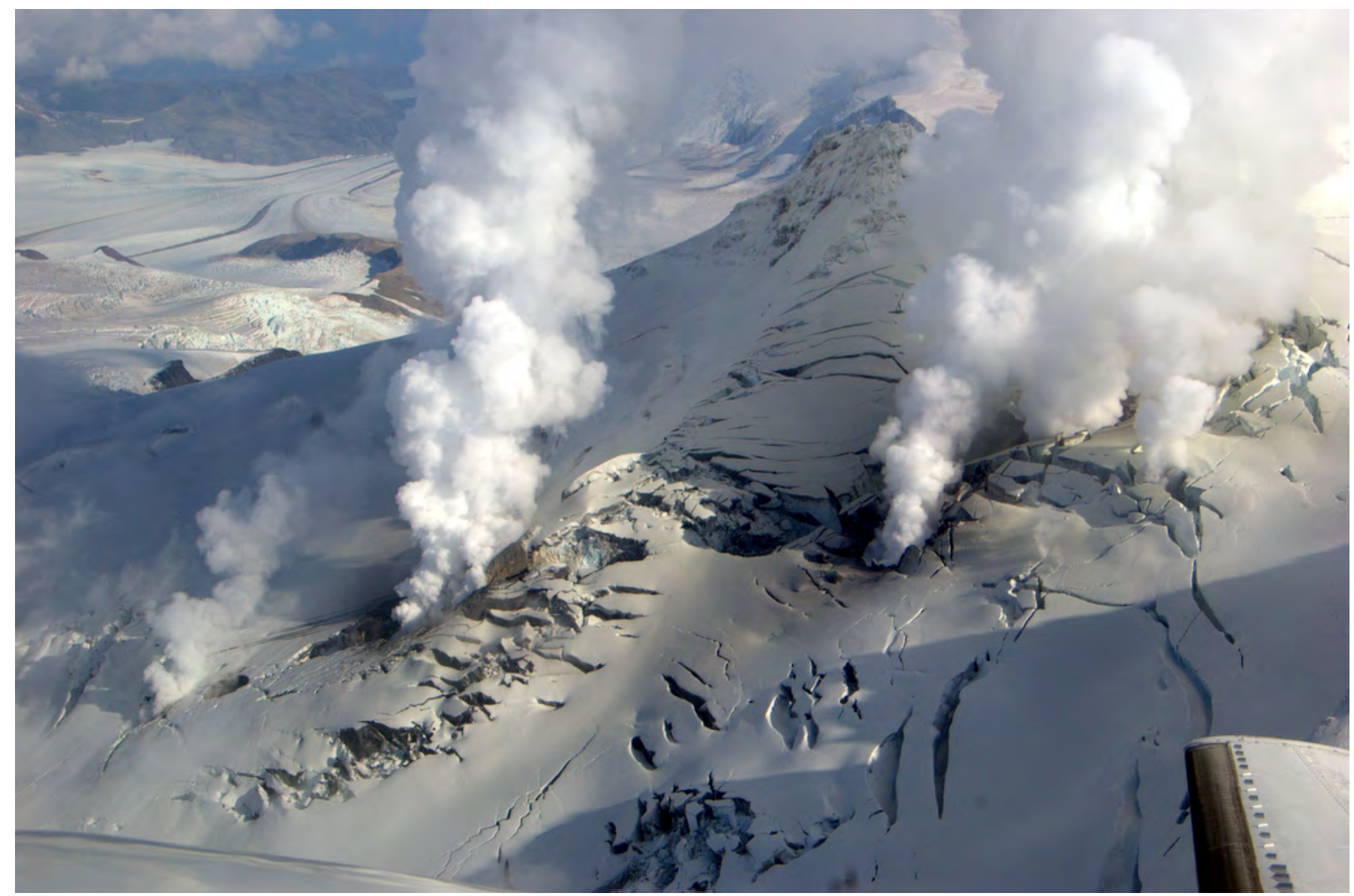

Figure 28. Aerial view of vents through glacial ice and the source of the September 17, 2006, eruption at Fourpeaked volcano. Distance from the uppermost steaming vent or pit to the lowermost is about $1,250 \mathrm{~m}(4,100 \mathrm{ft})$. View is to the east. Fourpeaked Glacier is marked by prominent medial moraines in the distance. The actual 6,903-ft ASL summit of Fourpeaked Mountain is obscured by steam at right. Photograph by C. Read, AVO/USGS, September 24, 2006. AVO database image at URL: http://www.avo.alaska.edu/image.php?id=11205.

ice and traveled an unknown distance into the Douglas River drainage (fig. 35). Levees of ice, sediment, and rock clasts as much as 10-15 m (33-50 ft) high marked the margins of the deposit. Where traced into the Douglas River drainage about 3-4 km (2-2.5 mi) from the glacier snout, the deposit was thin (about $2 \mathrm{~cm}$ or $0.8 \mathrm{in}$ ) and fine grained with a maximum clast size of about $1 \mathrm{~cm}(0.4 \mathrm{in})$. The field crew flew the length of the Douglas River to Cook Inlet and noted evidence of a flooding event represented by recently emplaced fine-grained gray sediment on beaches and river banks. On the day of observation, there was no evidence of continuing discharge of meltwater or debris down this newly carved drainage system. A map with a sketch of the upper outburst-flood deposits, location of vents and other relevant features is shown in figure 35 .
AVO scientists collected samples of the fine, gray ashfall deposit from the September 17 event (fig. 36). Deposits were most impressive west of the vent area where they were estimated to be $1-2 \mathrm{~mm}$ (less than 0.1 in) thick. Other flanks of the volcano received a mere dusting $(<1 \mathrm{~mm})$; based on these few observations and the outlier reports of extremely light ash fall noted at two distant locations, the fall deposit likely represents well under 1 million $\mathrm{m}^{3}$ of material. Preliminary petrographic analyses indicate the tephra consists of hydrothermally altered volcanic rock and crystal fragments, notably pyrite, and other accessory minerals (J. Larsen, UAFGI, written commun., 2006).

AVO geologists in the field on September 24-25 also reported loud rumbling sounds associated with sudden bursts of water from the ice-bedrock contact at an elevation of approximately 4,000 ft on the northwest flank of Fourpeaked; these flows lasted several seconds and then disappeared. 


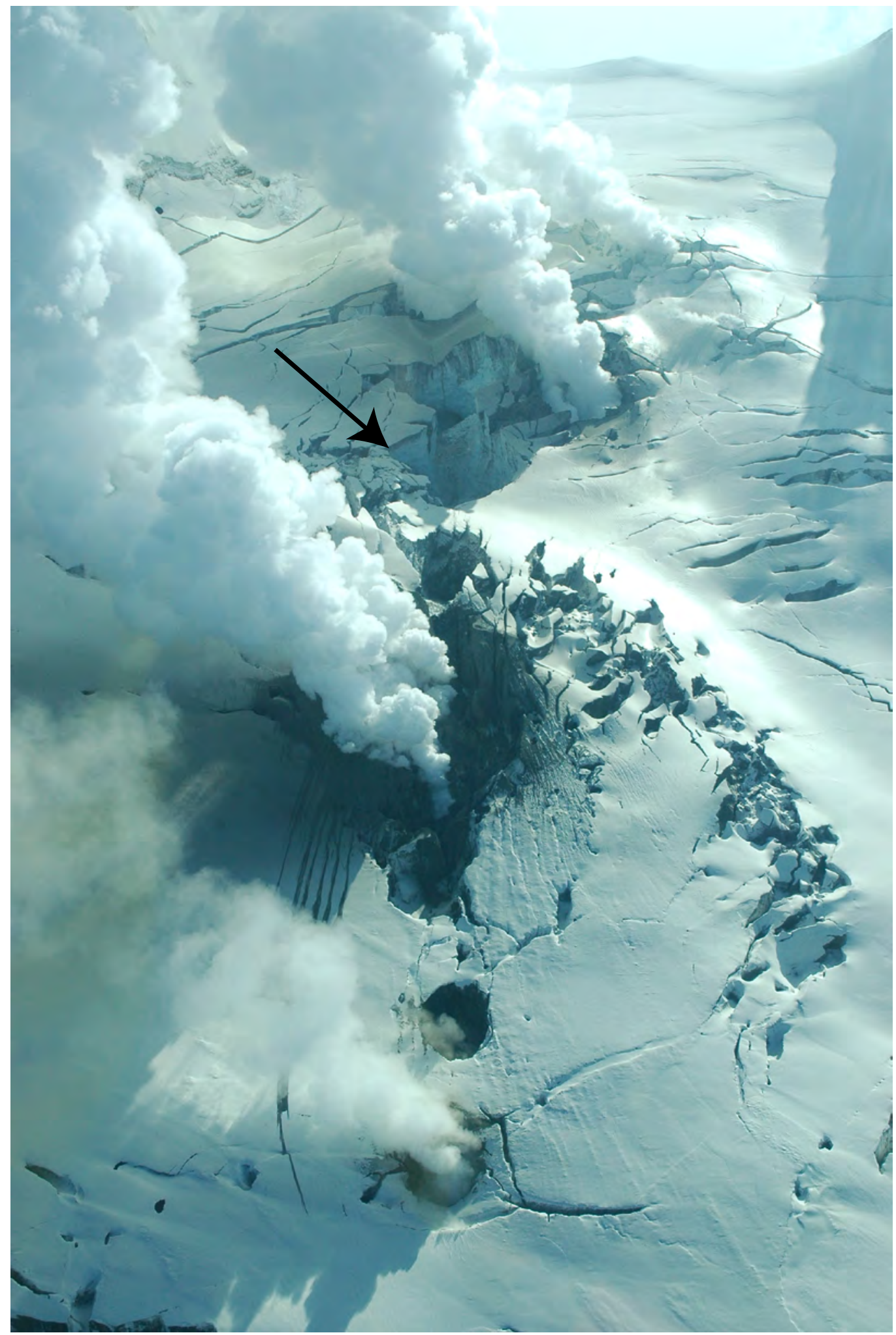

Figure 29. Aerial view of vents and pits through glacial ice and the source of the September 17, 2006, eruption at Fourpeaked volcano. Narrow rilling and dark surface flows of remobilized material emanate from the rim of the large central pit. Note dark fragmental material beneath new snow on the rim of the upper pits (arrow). Photograph by C.A. Neal, AVO/USGS, September 24, 2006. AVO database image at URL: http://www.avo.alaska.edu/image.php?id=11201. 


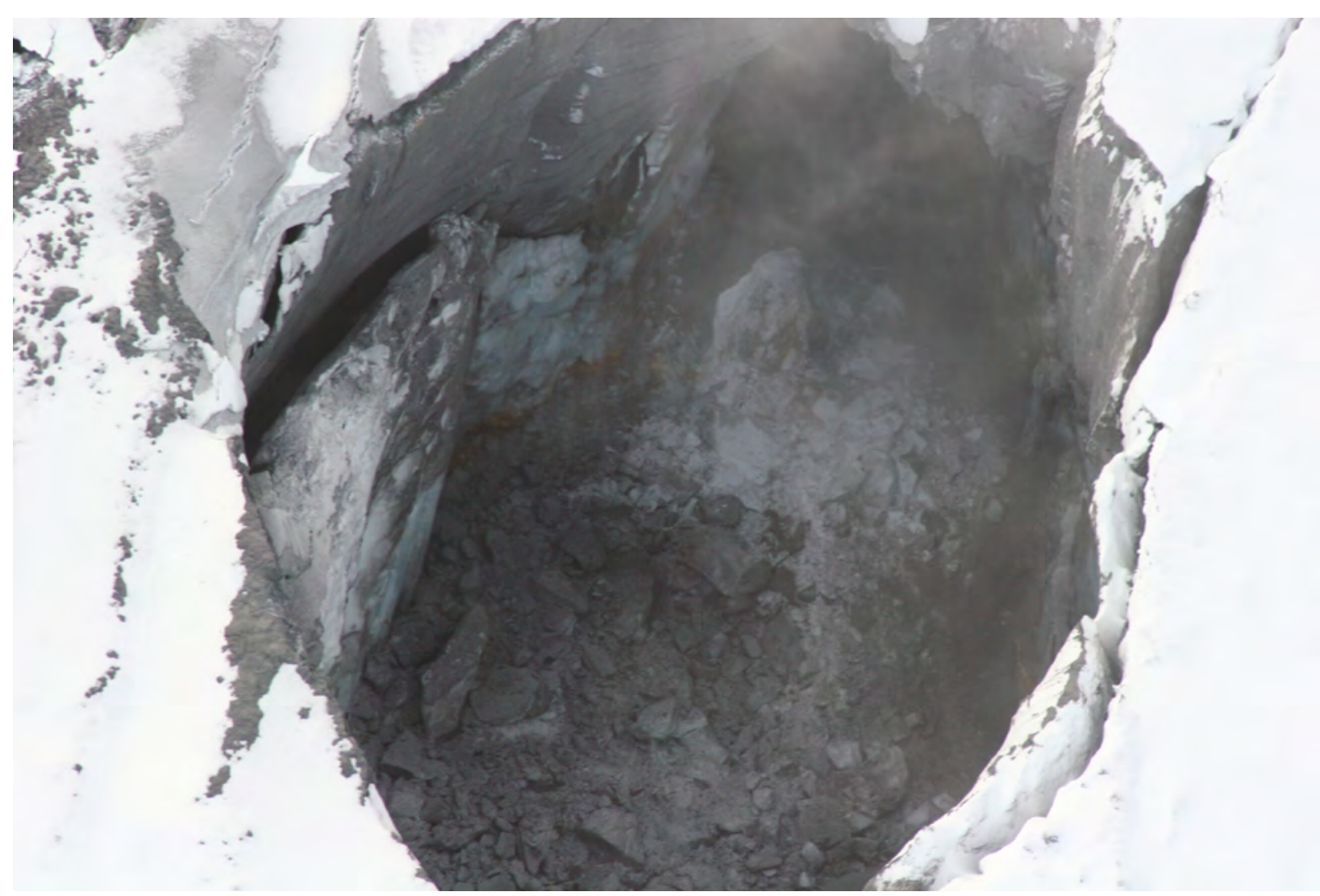

Figure 30. View into the bottom of one of the non-venting pits at Fourpeaked volcano. The diameter of this circular collapse pit is about $50 \mathrm{~m}$ (160 ft). Walls expose glacial ice. Ash-mantled blocks of ice lie in the bottom. Photograph by K.L. Wallace, AVO/USGS, September 25, 2006. AVO database image at URL: http://www.avo.alaska.edu/image.php?id=11858.

An overflight of the cliff below these outbursts did not reveal anything unusual, and any relationship between these periodic outbursts of water with the events of September 17 is uncertain.

AVO geologists made further ground-based observations of the deposits and features related to this unrest in midOctober. Close helicopter passes of the vent area on October 14 revealed that several of the original craters had coalesced and the rims of the sheer-walled pits had retreated, enlarging most by perhaps tens of meters. The pit rims were blanketed by fresh snow indicating no additional ash emission of significance since the explosion on September 17. However, intermittent, vigorous fumarolic activity capable of entraining a small amount of locally derived material may have continued and gone undetected between overflights. Field observers saw no sign of large ballistics littering the surface, so any ongoing phreatic emissions were not very energetic. Yellow-stained (most likely sulfur) snow surrounded the upper crater.
Deposits related to the outburst flood into the Douglas River were examined more closely and consisted of gray, soggy, water-saturated, sulfur-smelling silty material containing cobble-sized clasts of dense, altered, volcanic rock and pyrite (and possibly marcasite). Preliminary results from $\mathrm{x}$-ray diffraction and $\mathrm{x}$-ray fluorescence analyses of a nonpyritic material indicate that the volcanic rock composition primarily is dacite, and that the fine fraction also contains minor gypsum and minor smectite (K. Bull, ADGGS, written commun., 2007). Interestingly, near the snout of the glacier impacted by this outburst flood, AVO geologists noted multiple layers of similar, sulfurous, heterolithologic material exposed in the ice stratigraphy, and postulated that these may represent prior (possibly historical in age) debris-flow events captured in the ice.

Eight airborne gas measurements were obtained between September 23 and November 18, 2006. Sulfur dioxide output was steady and high for a non-erupting volcano ranging 


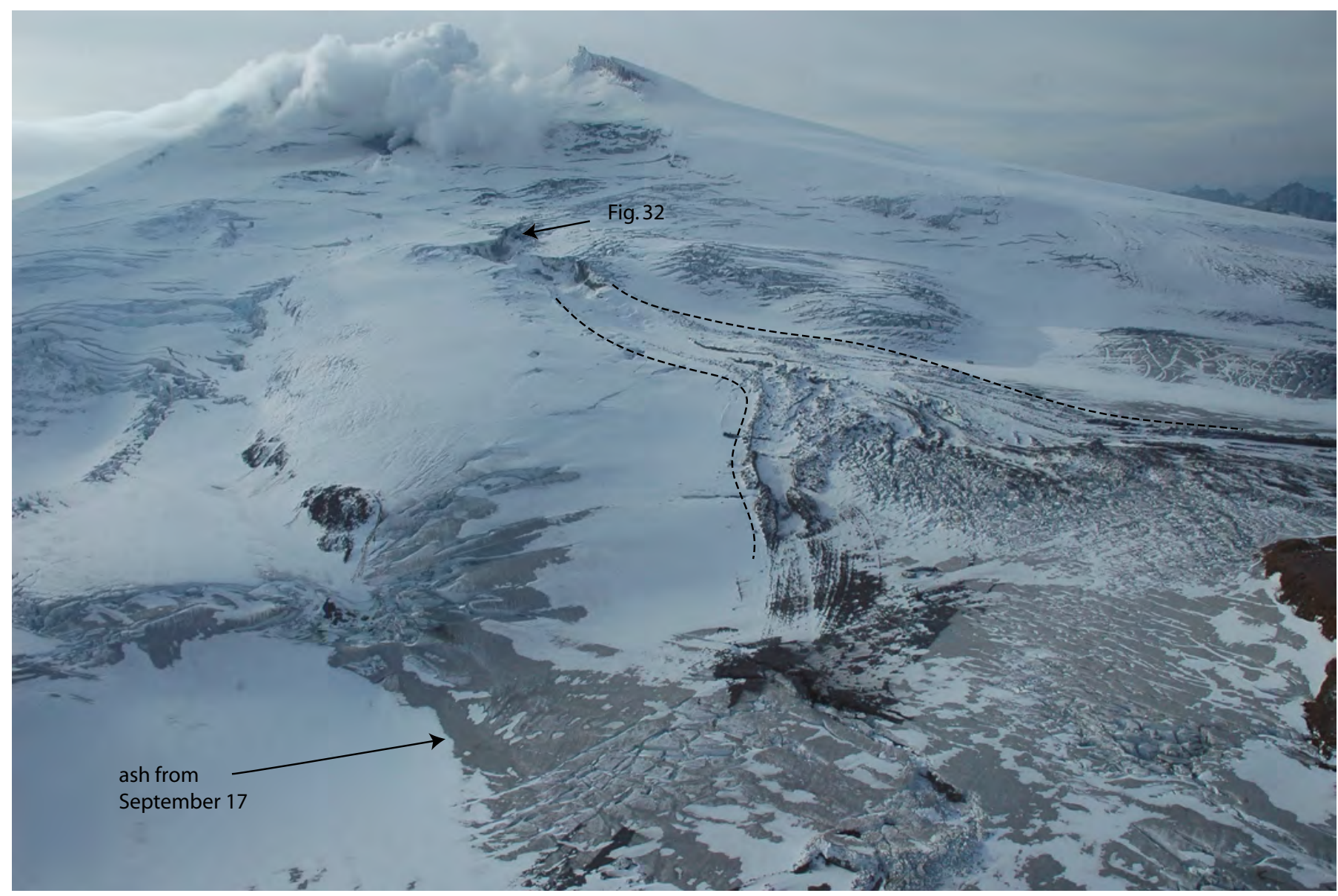

Figure 31. Aerial view of debris outflow chasm below the eruption site at Fourpeaked volcano. The primary path of the debris flow is marked by striated surface and prominent levees extending to the lower right from the steep-walled, ice-floored canyon (enclosed by dashed lines). Patches of fallout from the September 17 explosion still visible through new snow at lower left (arrow). Actively venting area is visible in the upper left near the volcano's summit. Photograph by R.L. Wessels, AVO/USGS, September 25, 2006. AVO database image at URL: http://www.avo.alaska.edu/image.php?id=11458.

between 820-2,940 ton/d (Doukas and McGee, 2007). For the same period, $\mathrm{CO}_{2}$ flux was between $340-834$ ton/d. In contrast to Augustine Volcano (McGee and others, 2006), $\mathrm{H}_{2} \mathrm{~S}$ output from Fourpeaked remained quite high, between 70-140 ton/d, likely reflecting the dominance of a wet hydrothermal system at this ice-clad volcano. In addition to these onsite, airborne measurements, Ozone Mapping Instrument (OMI) sensors occasionally detected $\mathrm{SO}_{2}$ clouds in the area. Beginning in October, low sun angles prevented good results and AVO stopped receiving reports from the OMI satellite team at the University of Maryland (D. Schneider, USGS, oral commun., 2006).
Seismic activity as recorded on the three new stations installed following the event on September 17 remained relatively low through the end of the year, typically with only a few volcanic earthquakes captured on most days. These three stations augmented coverage by regional seismic station CCDN about $17 \mathrm{~km}(\sim 11 \mathrm{mi})$ northeast of Fourpeaked. On October 3, a swarm consisting of tens to hundreds of very small, non-locatable earthquakes occurred in the vicinity of Fourpeaked. A second swarm on November 5-6 occurred within the new Fourpeaked subnet and 75 events were located. Seismicity remained elevated with occasional small swarms of activity (10 located events per day or less) through the end of the year. Small explosion signals also began to be recorded in the spring; these signals may have reflected transient increases in fumarolic emission. 


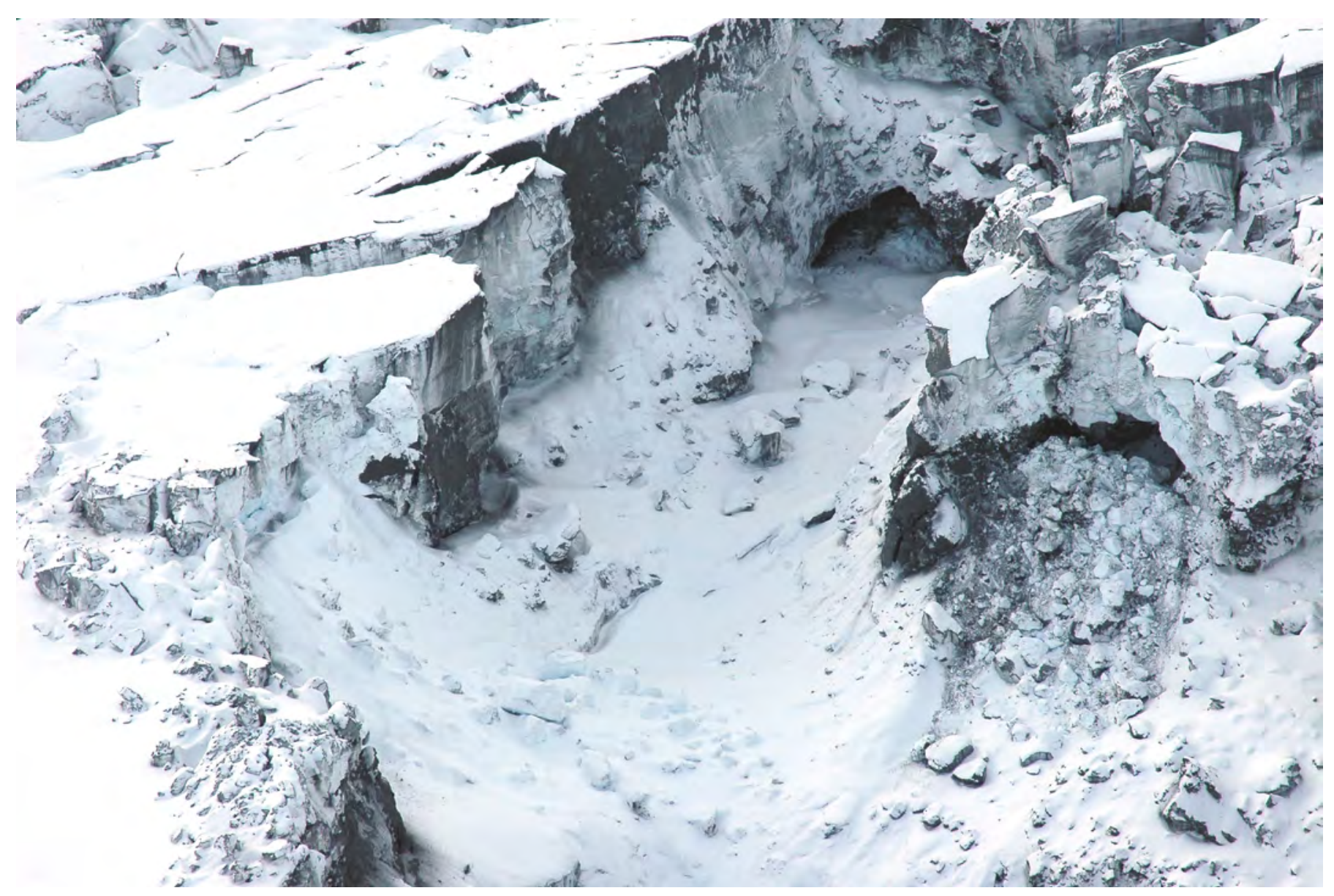

Figure 32. Close-up photograph of the cavernous point of origin of the September 17, 2006, outflow event at an elevation of about $5,000 \mathrm{ft}(1500 \mathrm{~m})$ on the glacier draining the northwest flank of Fourpeaked volcano. Relief from the pre-eruption glacier surface to the bottom of the incised channel is on the order of $100 \mathrm{~m}$ (330 ft). This area was covered with new snow between September 17 and 25. Dark material draping ice faces is inferred to be fallout from the September 17 event. See fig. 31 for location of this image. Photograph by K.L. Wallace, AVO/USGS, September 25, 2006. AVO database image at URL: http://www.avo.alaska.edu/image.php?id=11837.

Further analysis of Katmai area seismic stations during the time period of the eruption cloud and opening of vents in the ice revealed a small swarm of earthquakes between 11:48 a.m. and 3:50 p.m. ADT on September 17 (M. West, UAFGI, oral commun., 2006) coincident in time with the onset and development of the plume seen in radar images. The University of Alaska Fairbanks infrasound array also detected a signal at about 20:50 UTC on September 17, likely an explosion source, at a time and location consistent with the plume sighting (S.R. McNutt, UAFGI, oral commun., 2006).

AVO concluded that the unrest at Fourpeaked volcano most likely involved the presence of new magma at fairly shallow (less than a few kilometers) levels, accounting for the seismicity and degassing, and providing a heat and gas source for a phreatic explosion, vigorous phreatic emission of gas and fine particulates, and a glacial outburst of meltwater, glacial ice, and hydrothermally altered debris on September 17.
A shallow, degassing intrusion of fresh magma also would account for the ongoing gas emissions (K. McGee, USGS, oral commun., 2006). The lack of a seismic network at Fourpeaked precludes exact determination of the onset of seismicity that may have been associated with an intrusion. However, the swarm detected on the Katmai network on September 17 likely captured the most vigorous phase of the event, including the onset of phreatic eruption.

Through the remainder of 2006 and into 2007, a variably robust plume of vapor and volcanic gas discharged from the linear chain of pits in the ice. Overflights into mid-November documented minor changes in the pit morphologies, primarily related to coalescence and widening. No further ash emissions of significance were noted, although an increasingly visible coating of a yellow, likely sulfurous deposit stained snow and ice cover around the Fourpeaked summit. 


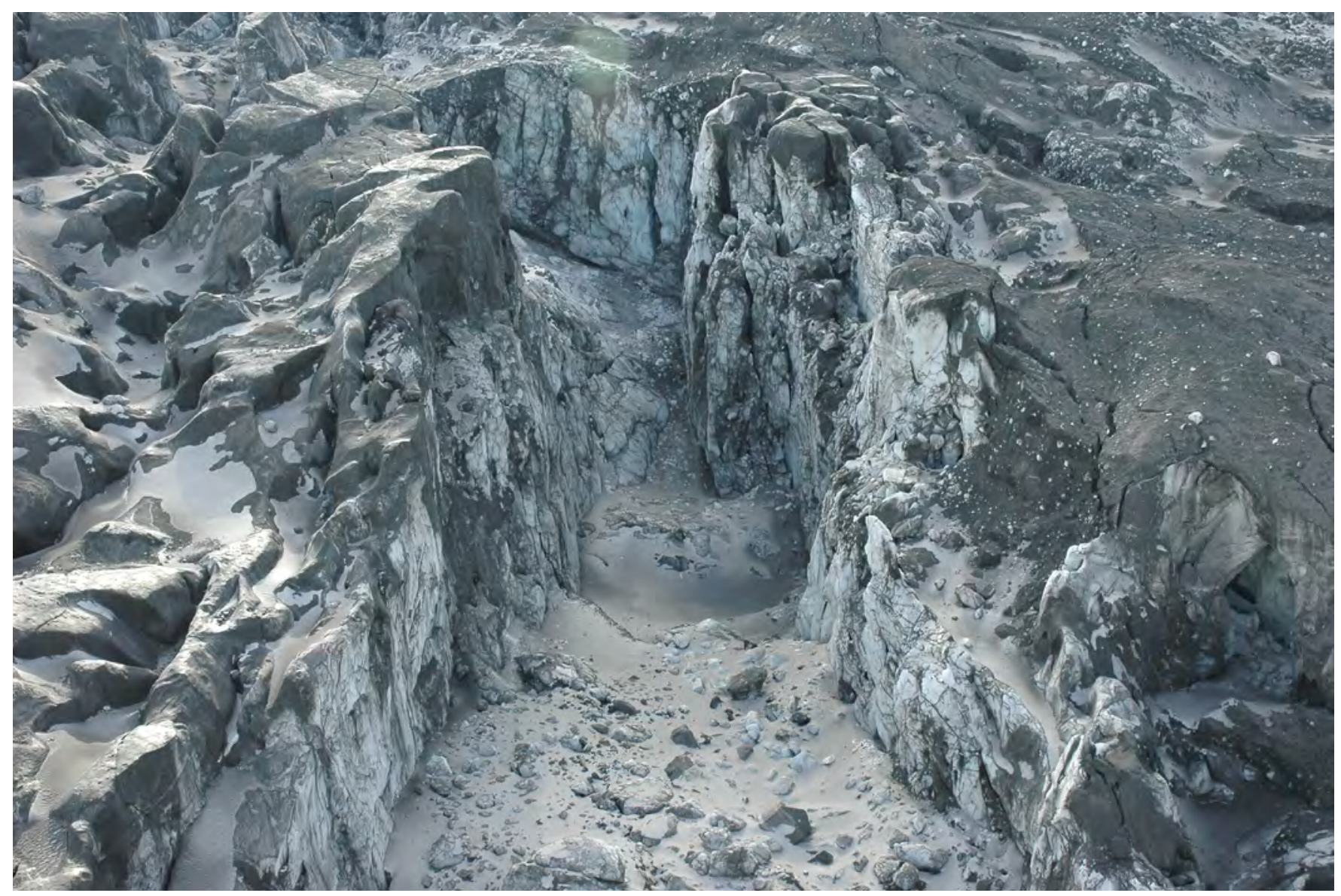

Figure 33. View looking upslope into the deeply incised canyon produced during the outflow event (see fig. 35 for the approximate location of image.) Canyon walls are on the order of 50-100 m (160-330 ft) tall; the width of the outflow channel is about $100 \mathrm{~m}$ $(330 \mathrm{ft})$. White ice blocks within dark matrix indicate that the glacier surface adjacent to the canyon was overrun by a debris flow prior to or coincident with incision of the canyon. Photographic and field evidence suggest multiple pulses of debris flow generation, perhaps spanning the duration of ash fallout on September 17. Although taken on the same day as figure 32, there is no new snowfall covering this area which was likely below snow-line. Photograph by K.L. Wallace, AVO/USGS, September 25, 2006. AVO database image at URL: http://www.avo.alaska.edu/image.php?id=11848.

In response to the eruption and continuing fumarolic activity at Fourpeaked, AVO mounted a number of observational and FLIR overflights and geologic site visits by fixed wing and helicopter. Airborne gas measurements were important in defining the magmatic contribution to the unrest. AVO installed three new telemetered short-period seismic stations and a temporary broadband station to track earthquake activity and also installed a web camera $16 \mathrm{~km}(10 \mathrm{mi})$ north of the volcano. A fourth seismic station near Douglas Volcano was repaired. AVO ruled out installation of any deformation monitoring equipment due to cost and the challenging icecovered terrain. AVO hosted a number of widely attended scientific discussion and coordination calls during the first few months of unrest at Fourpeaked. AVO also deployed a forward stash of helicopter fuel to Hallo Bay south of Fourpeaked and commercial aerial photography was flown in October.
A high level of interest in the surprise renewal of activity at a volcano thought to be inactive prompted AVO to visit National Park Service (NPS) offices in King Salmon in the weeks following the eruption. During their visit, AVO staff described the event, likely outcomes, and hazards of concern at the time. The NWS issued a one-time SIGMET when AVO declared Level of Concern Color Code YELLOW, but no formal notices or restrictions on air traffic were put in place. On September 25, based on the accumulated data and field observations, AVO issued an information release summarizing the eruption, Fourpeaked geology and eruptive history, and describing the range of possible outcomes of this period of unrest. 


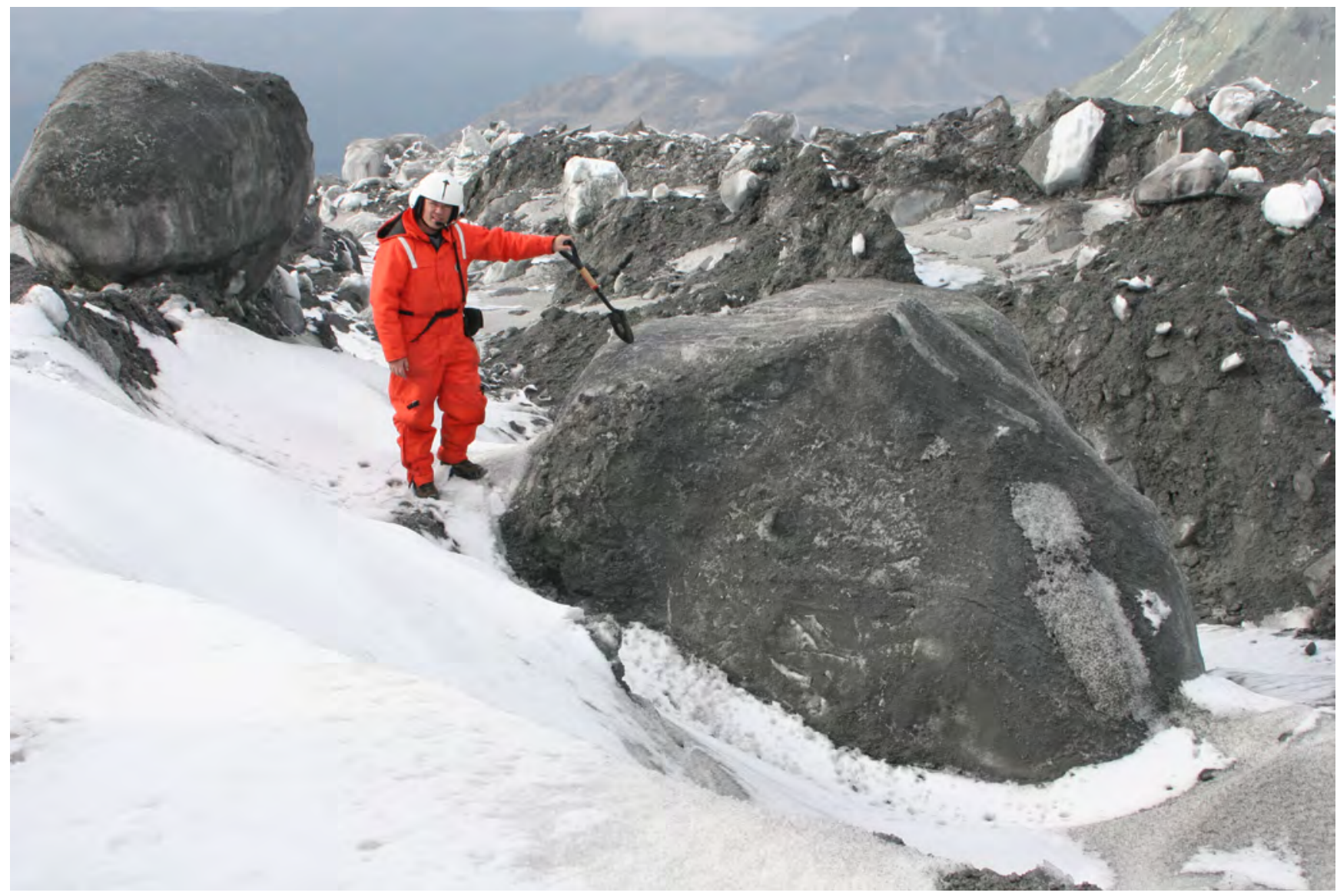

Figure 34. Block of glacial ice in levee produced by the outburst flood from Fourpeaked volcano, September 17, 2006. Geologist stands atop new snowfall that blankets a mixture of hydrothermally altered material and ice of varying clast sizes. At this location, the channel width between levees was about $500 \mathrm{~m}(1,640 \mathrm{ft})$ across. See fig. 35 for the location of this image. The largest ice clasts in this deposit were as much as 5-10 m (16-33 ft) across. Photograph by K.L. Wallace, AVO/USGS, September 25, 2006. AVO database image at URL: http://www.avo.alaska.edu/image.php?id=11677.

In October 2006, Oliver Holm of Kodiak contacted AVO to share an intriguing historical observation of a steam and gas plume at or near the summit of Fourpeaked. The sighting occurred during the summer of 1965 during a boat trip up Shelikof Strait, when Holm saw a steam plume coming from at, or near, the summit of Fourpeaked. Holm reports that the plume was about the same height as the mountain is tall, from his perspective, suggesting a column several thousand feet in vertical extent. He did not notice any ash on the snow, or any discoloration in the plume. The report seems quite credible, however, and combined with geologic observations of highly altered bedrock in the summit area, argues for a periodically re-invigorated hydrothermal system at Fourpeaked.
Other than this one historical report of steaming noted above, Fourpeaked is not known to have erupted historically and the age of the last eruption is not known but is thought to be pre-Holocene (J. Fierstein, USGS, oral commun., 2006). The range of sizes and styles of past eruptions are not well constrained, however, past eruptions of andesite and dacite indicate that eruptions of Fourpeaked can be explosive, possibly producing plumes that reach in excess of $10 \mathrm{~km}$ $(33,000 \mathrm{ft}) \mathrm{ASL}$ and local ash fall. Fourpeaked lies within the northeast corner of Katmai National Park and Preserve on the Alaska Peninsula, $7.5 \mathrm{mi}(12 \mathrm{~km})$ southwest of Mount Douglas. The volcanic edifice consists of small, isolated exposures of lava along ridge crests and cliff faces that radiate out from the ice-covered summit. 


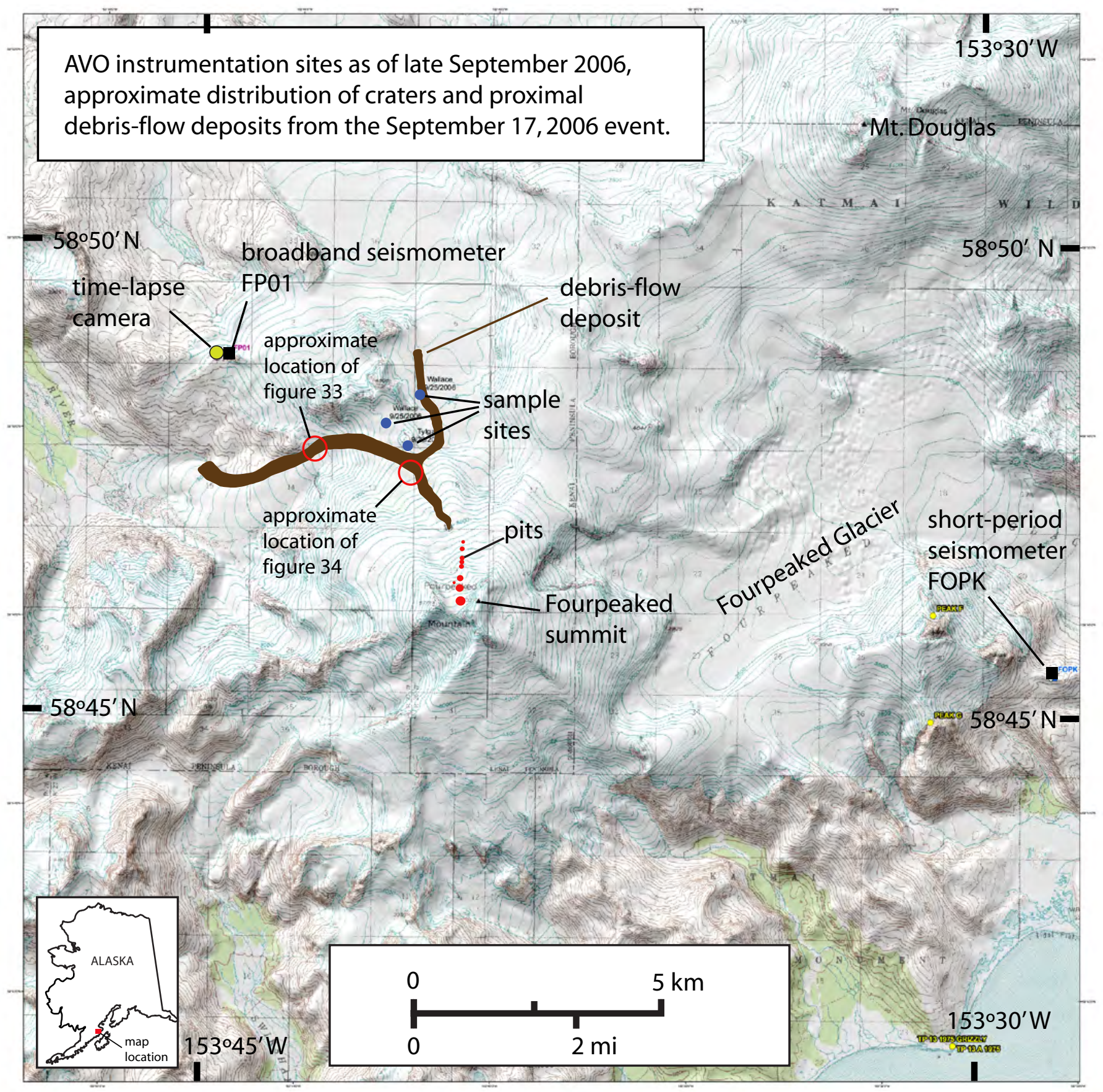

Figure 35. Preliminary map of selected features and deposits related to the September 17, 2006, eruption of Fourpeaked volcano. Modified from K.L. Wallace and R.L. Wessels, AVO/USGS. 


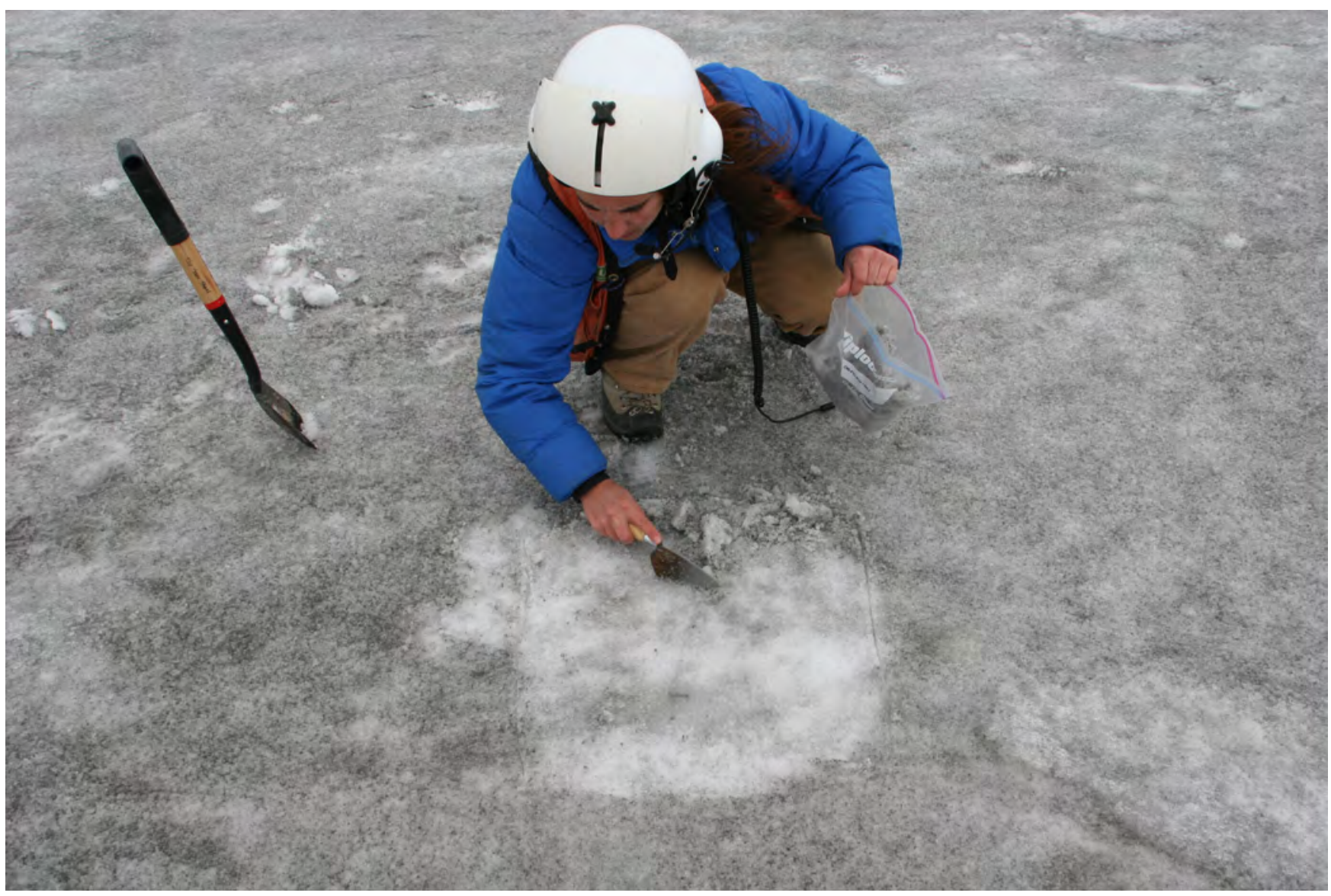

Figure 36. Alaska Volcano Observatory geologist samples very fine dusting of ash from the September 17, 2006, phreatic eruption of Fourpeaked volcano. This site is atop the glacier surface north-northwest of the Fourpeaked summit (fig. 35). Photograph by R.L. Wessels, AVO/USGS, September 25, 2006. AVO database image at URL: http://www.avo.alaska.edu/image.php?id=11675. 


\section{KATMAI GROUP: Mount Martin}

CAVW\# 1102-14

$58^{\circ} 10^{\prime} \mathrm{N} 155^{\circ} 21^{\prime} \mathrm{W}$

$1,860 \mathrm{~m}(6,102 \mathrm{ft})$

Alaska Peninsula

SEISMIC SWARM does not lead to eruption

Mount Martin, one of the Katmai group of volcanoes on the Alaska Peninsula, has no confirmed historical eruptions, but has a very active fumarolic field within a large, open crater at its summit (fig. 37). Over the years, AVO has often received reports of vapor plumes above Mount Martin from pilots or from residents of the King Salmon and Naknek communities about $100 \mathrm{~km}$ (62 mi) from the volcano. Periodic airborne-gas surveys of Mount Martin show consistent outgassing of $\mathrm{CO}_{2}$, $\mathrm{H}_{2} \mathrm{~S}$, and $\mathrm{SO}_{2}$ (Doukas and McGee, 2007).

On January 10, 2006, AVO raised the Level of Concern from GREEN to YELLOW after a sharp increase in earthquake activity beneath Mount Martin that had begun on January 8 (Dixon and others, 2007). Roughly 300 earthquakes were located in just over 2 days (fig. 38), a significant increase over the long-term average rate of less than one event per day since the seismic network was installed in 1996. Satellite data did not indicate any obvious changes at the surface.

Elevated seismicity continued for about 2 weeks after which the rate of shallow volcano-tectonic earthquakes decreased to levels considered background for Mount Martin. On January 27, AVO downgraded the Level of Concern to GREEN. Throughout this seismic swarm, no surface manifestations of the increase in seismicity were noted in satellite imagery or by passing pilots. The cause of this swarm remains uncertain (John Power, USGS, oral commun., 2007).

Mount Martin and adjacent Mount Mageik are stratovolcanoes within Katmai National Park and Preserve on the Alaska Peninsula (fig. 1) about $475 \mathrm{~km}$ (295 mi) southwest of Anchorage. Martin's summit cone sits at an elevation of roughly $1,860 \mathrm{~m}(6,102 \mathrm{ft})$. A summit crater about $300 \mathrm{~m}(980$ $\mathrm{ft}$ ) across contains an ephemeral, shallow lake, and vigorous fumaroles that emit jets of sulfur-rich, volcanic gases (fig. 37). No historical eruptions of Mount Martin are known, but the fumarolic field frequently produces towering vapor plumes as high as 1,000 $\mathrm{m}(\sim 3,300 \mathrm{ft})$ above its summit. A series of thick lava flows, the oldest of which were emplaced prior to about 6,000 years ago, extend north and northwest from the summit crater area (Fierstein and Hildreth, 2001).

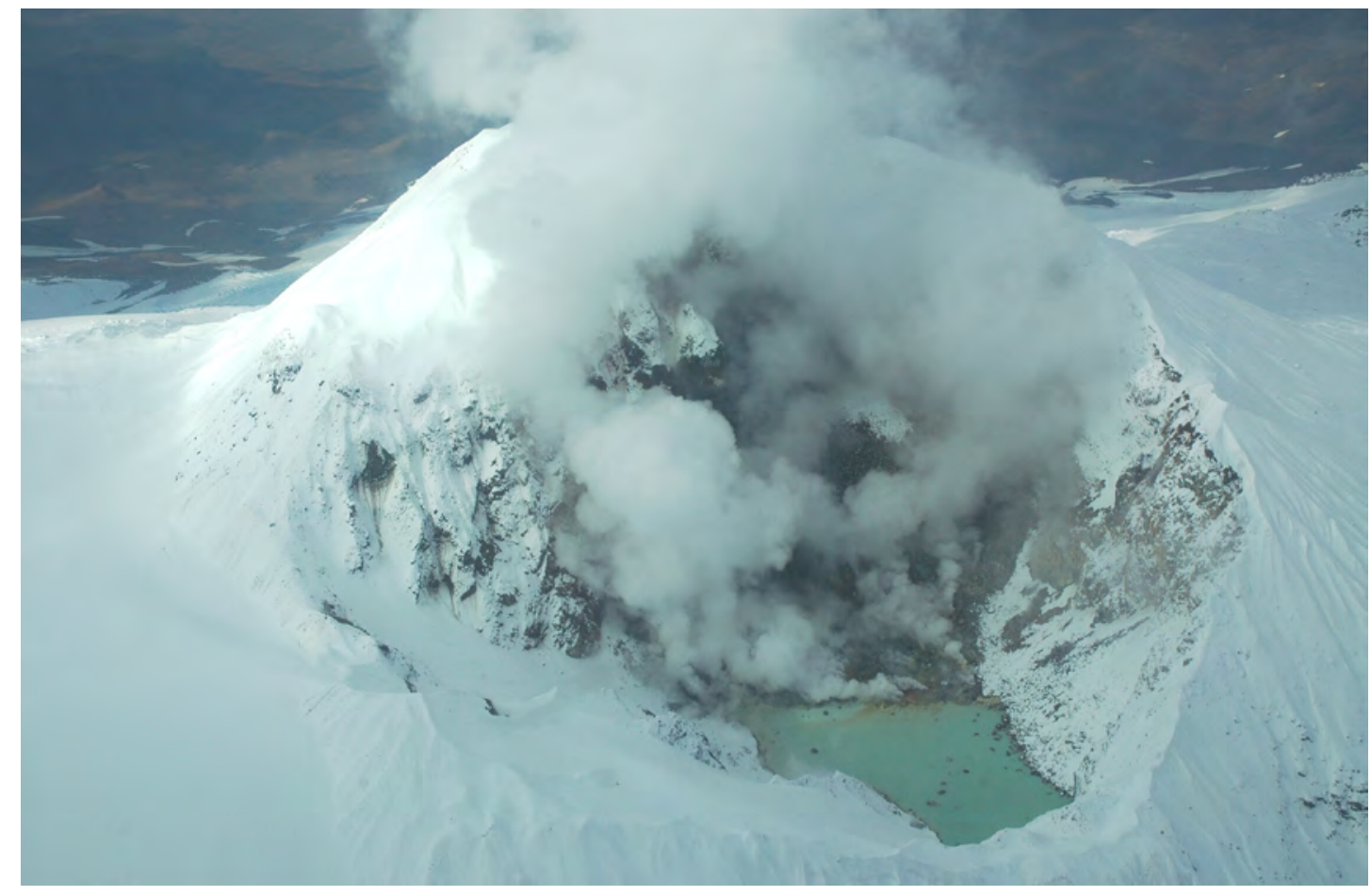

Figure 37. Summit crater, shallow lake, fumaroles, and plume at Mount Martin, one of the Katmai group volcanoes. Photograph by C.A. Neal, AVO/USGS, September 24, 2006. AVO database image at URL: http:// www.avo.alaska.edu/image.php?id=11182. 
Martin/Mageik Volcano Seismicity 01-Jan-2006 - 01-Feb-2006
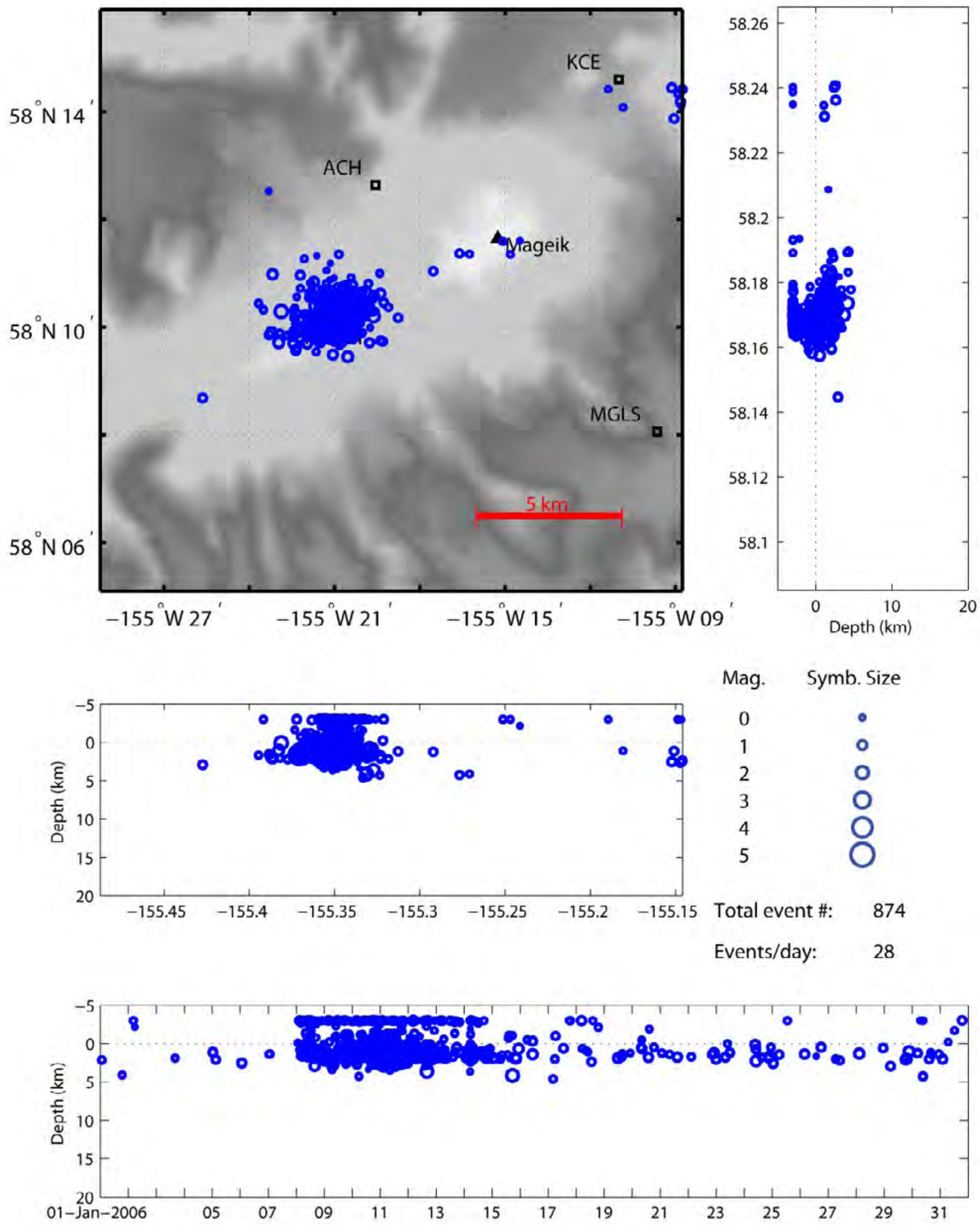

Figure 38. Seismicity reflecting the seismic swarm at Mount Martin, January 2006. 


\section{Mount Veniaminof Volcano}

CAVW\# 1102-07

$56^{\circ} 12^{\prime} \mathrm{N} 159^{\circ} 23^{\prime} \mathrm{W}$

$2,507 \mathrm{~m}(8,225 \mathrm{ft})$

Alaska Peninsula

MINOR PHREATIC AND STROMBOLIAN (?) ERUPTION Intermittent, small, ash-poor plumes from the intracaldera cone. Ash fall limited to ice-filled summit caldera

Long-term, low-level eruptive activity at Veniaminof Volcano had diminished in frequency and intensity in late 2005 (McGimsey and others, 2007) and the volcano began 2006 at Level of Concern Color Code GREEN. Weak ash emissions resumed in early March and were captured on the AVO web camera, prompting AVO to raise the Level of Concern Color Code to YELLOW on March 3. These eruptions of ash were very minor, producing small, diffuse plumes that rose at most a few hundred meters above the intracaldera cinder and spatter cone (fig. 39). Ash clouds dissipated rapidly and did not extend far beyond the caldera rim. Any fallout was mostly confined to within the caldera as well.

Intermittent, low-altitude emissions of steam and ash continued infrequently through the spring and into summer. A pilot reported an ash plume reaching $10,000 \mathrm{ft}$ (about $2,000 \mathrm{ft}$ above the summit of the cone) on April 6 and again on June 16; deposits from some of these ash bursts were photographed by passing aircraft (fig. 40). The Veniaminof seismic network experienced outages throughout the year, hampering AVO's ability to locate seismicity at the volcano.

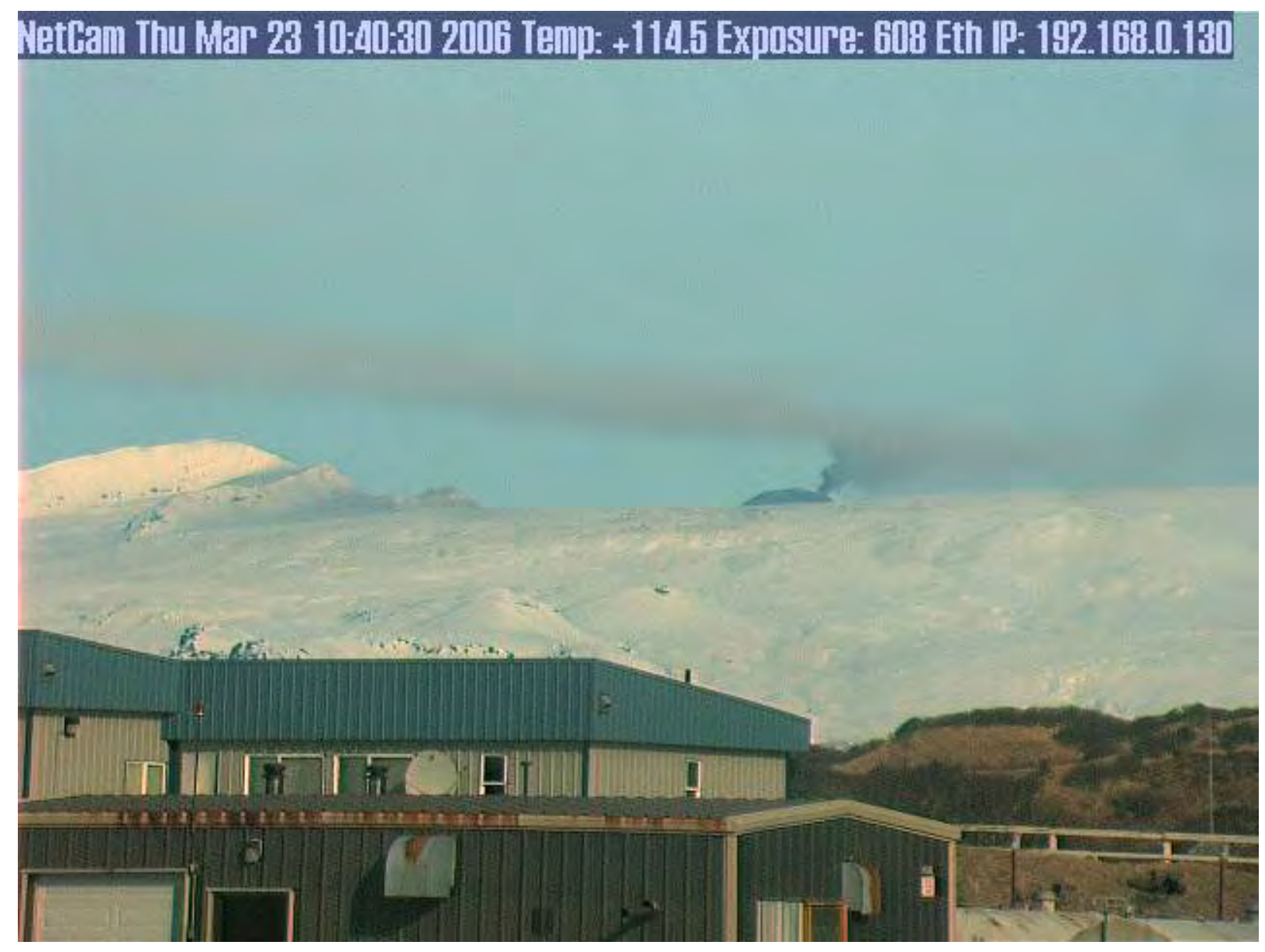

Figure 39. Alaska Volcano Observatory web camera image from Perryville showing a low-level ash and gas emission from the intracaldera cone of Veniaminof Volcano, March 23, 2006. This level of activity was observed intermittently at Veniaminof throughout 2006. No ash fall on nearby Perryville (see fig. 1 for location) was reported to AVO. 
Seismicity remained low but above background for the remainder of 2006. Web camera views, when clear, almost always showed a wispy vapor plume above the intracaldera cone. Toward the end of October and into the first few days of November, small steam and ash bursts rose a few hundred meters above the intracaldera cone as seen in the AVO web camera - a slight intensification of ash production compared to the previous 5 months. A weak thermal anomaly coincided with this period of increased activity, but ash from these small bursts did not travel beyond the caldera rim. Following the November activity, no further ash emissions were detected on the web camera through year's end. Frequent periods of poor weather, however, may have hidden minor activity. Compared to more vigorous eruptive pulses in previous years when incandescent material was sighted on the web camera and by residents, 2006 was a quiet year for Veniaminof Volcano. GPS sites on and around the volcano were not reoccupied in 2006 precluding further analysis of possible volcanic deformation reported by Fournier and Freymueller (2006).
Veniaminof is an andesitic stratovolcano with an icefilled, $10-\mathrm{km}$ diameter $(6 \mathrm{mi})$ summit caldera on the Alaska Peninsula, $775 \mathrm{~km}$ (480 mi) southwest of Anchorage and 35 $\mathrm{km}(22 \mathrm{mi})$ north of Perryville (fig. 1). Veniaminof is one of the largest and most active volcanoes in the Aleutian Arc (Miller and others, 1998). Low-level Strombolian and phreatic (?) ash explosions from the approximately 350-m-high $(1,150 \mathrm{ft})$ intracaldera cone have occurred intermittently since 2002 (McGimsey and others, 2005b; Neal and others, 2005a, 2005b). The last significant magmatic eruption occurred in 1993-95 (Neal and others, 1995b; McGimsey and Neal, 1996; Neal and others, 1996). This eruption was characterized by intermittent, low-level emissions of steam and ash, and production of a small lava flow that melted a pit in the calderaice field. Previous historical eruptions have produced ash plumes that reached 6,000 $\mathrm{m}(\sim 20,000 \mathrm{ft}) \mathrm{ASL}$ and ash fallout that affected areas within about $40 \mathrm{~km}(25 \mathrm{mi})$ of the volcano.

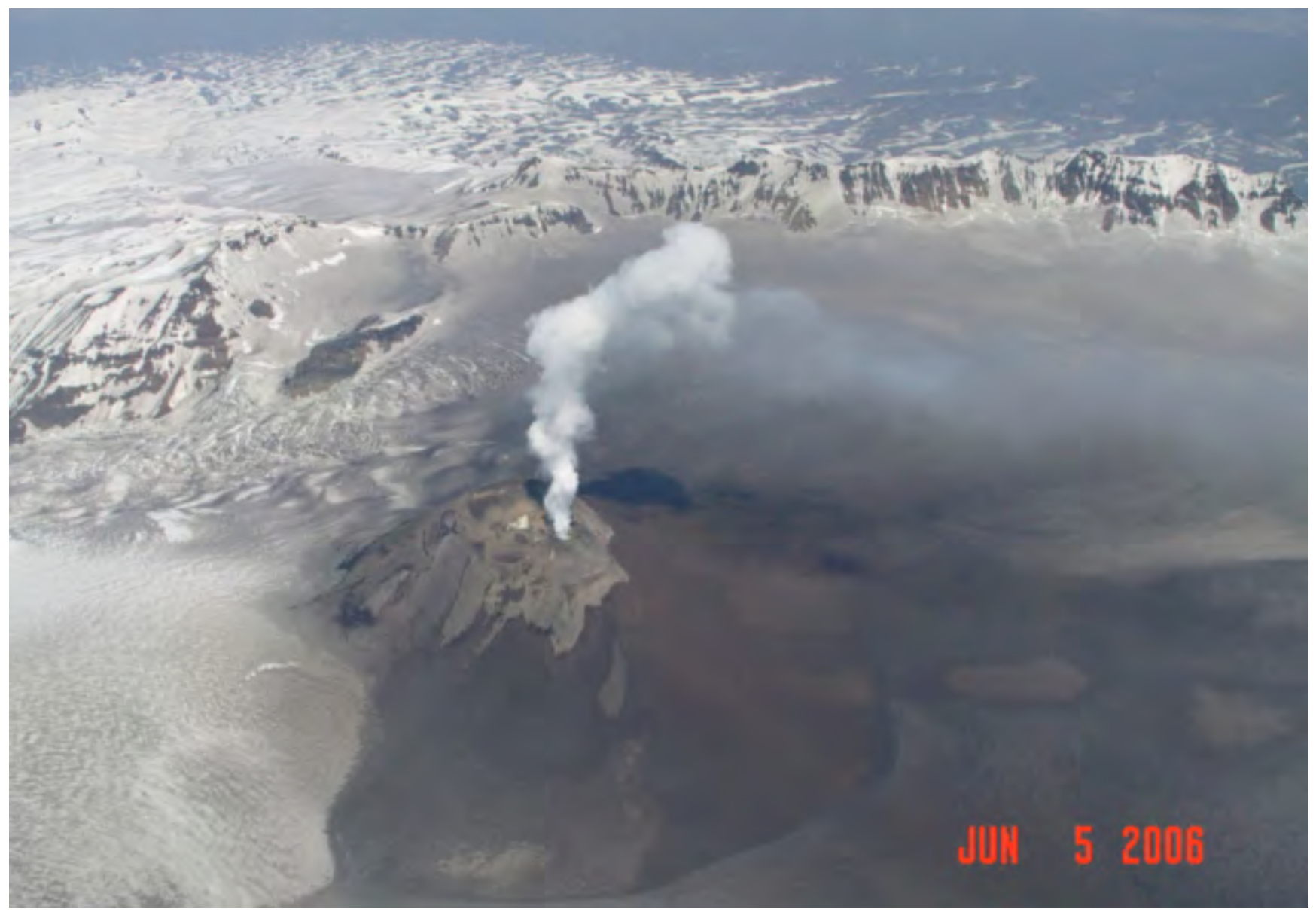

Figure 40. Aerial view of the summit caldera of Veniaminof Volcano, June 5, 2006. The approximately 350-m-high (1,150 $\mathrm{ft})$ intracaldera cone is producing a prominent steam plume, possibly containing other volcanic gases, that rises a few hundred meters above the ground; recent ash fall on the ice surface is indicated by the extensive area of brownish-gray discoloration. Darker brown areas on cone probably are wetter areas due to snow and ice melt and greater exposure of cone scoria. View looking north-northeast. Photograph by Sam Egli (used with permission) of Egli Air. AVO database image at URL: http://www.avo.alaska.edu/image.php?id=11026. 


\section{Cleveland Volcano}

CAVW\# 1101-24

$52^{\circ} 49^{\prime} \mathrm{N} 169^{\circ} 57^{\circ} \mathrm{W}$

$1,730 \mathrm{~m}(5,676 \mathrm{ft})$

Chuginadak Island, east-central Aleutian Islands

INTERMITTENT EXPLOSIONS

Ash clouds, thermal anomalies

Cleveland volcano on Chuginadak Island in the central Aleutians (fig. 1) is unmonitored by ground-based instrumentation. In an area of frequent thick cloud cover, even satellite remote sensing is severely limited in application to reliably detect thermal anomalies and ash clouds resulting from explosions. Activity at Mount Cleveland in 2006 included a possible increase in frequency of explosions compared to the years immediately following the three significant eruptions of 2001 (table 8; Dean and others, 2004; McGimsey and others, 2007).

The first known explosive eruption in 2006 occurred on February 6, and was detected in routine Advanced Very High Resolution Radiometer (AVHRR) satellite image analysis by
AVO staff. Satellite-derived temperatures indicated an initial cloud height of about 6-8 km (22,000-26,000 ft). The eruption appeared to be short lived and had ceased several hours before detection on satellite imagery, but AVO raised the Level of Concern Color Code to RED and NWS issued a SIGMET. The cloud was tracked for more than $400 \mathrm{~km}(250 \mathrm{mi})$ southeast of the volcano before it largely dissipated in satellite images. By day's end, with no further reports or images of ash production at Cleveland, AVO downgraded the Color Code to ORANGE. For the duration of condition RED, the FAA imposed a temporary flight restriction (TFR) from the surface to $50,000 \mathrm{ft}$ within a 5 nautical mile radius of the volcano.

Table 8. 2006 activity at Cleveland volcano, compiled from Alaska Volcano Observatory information-release statements, internal-log entries, and summaries.

[Information shared by J. Dehn, University of Alaska, Fairbanks Geophysical Institute (UAFGI). AVO, Alaska Volcano Observatory; AVHRR, Advanced Very High Resolution Radiometer satellite imagery; ISS, International Space Station; PUFF, a volcanic ash tracking model; km, kilometer; ft, foot]

\begin{tabular}{|c|c|c|}
\hline Date & Observation & Source or comments \\
\hline February 6 & $\begin{array}{l}\text { Ash cloud eruption detected in AVHRR data to } 8 \mathrm{~km} \text { based } \\
\text { on satellite temperatures and PUFF comparison. }\end{array}$ & $\begin{array}{l}\text { Ash cloud tracked as far as } 423 \mathrm{~km} \text { downwind in } \\
\text { AVHRR imagery. Thermal anomalies associated with } \\
\text { this event. }\end{array}$ \\
\hline March 24 & Possible ash cloud in satellite data. & Very low-level, possibly orographic. \\
\hline May 5 & Possible ash cloud in satellite data. & Thermal anomalies associated with this event. \\
\hline May 23 & $\begin{array}{l}\text { Ash cloud photographed and observed in AVHRR, satellite } \\
\text { estimated cloud top } 22,000 \mathrm{ft} \text {. }\end{array}$ & $\begin{array}{l}\text { Reported by astronaut aboard the ISS (fig. } 41 \text { ). } \\
\text { Thermal anomalies associated with this event. } \\
\text { Detected also on UAFGI infrasound array. }\end{array}$ \\
\hline August 24 & $\begin{array}{l}\text { Ash cloud, ash fall, eruption in progress. Visually estimated } \\
\text { cloud top } 10,000 \mathrm{ft} \text {. Followed by intermittent faint thermal } \\
\text { anomaly in satellite images. }\end{array}$ & $\begin{array}{l}\text { Filmed and reported by mariners (fig. } 42 \text { ). Also } \\
\text { detected on infrasound array at UAFGI. }\end{array}$ \\
\hline October 28 & $\begin{array}{l}\text { Ash cloud, pilot estimate of cloud above the volcano at } \\
36,000 \mathrm{ft} \text { and a lower portion drifting east northeast at } 30,000 \mathrm{ft} \\
\text { (approximately } 0000 \mathrm{UTC} \text { ). AVO analysis of satellite } \\
\text { imagery about } 30 \text { minutes later suggested a minimum } \\
\text { of } 15,000 \mathrm{ft} \text { based on cloud-top temperature. }\end{array}$ & $\begin{array}{l}\text { Pilot report initial notification; subsequent satellite } \\
\text { data confirms cloud. Lahar deposits extending } \\
\text { down from the summit seen in satellite data from } \\
\text { November } 4 \text {. Thermal anomalies associated with this } \\
\text { event. }\end{array}$ \\
\hline November 6 & Infrasound signal received at UAFGI. & $\begin{array}{l}\text { Cleveland origin permissible; also could have been a } \\
\text { Seguam event. }\end{array}$ \\
\hline Late October-late November & New rockfalls, avalanches. & $\begin{array}{l}\text { Satellite data confirms some explosive activity } \\
\text { between October } 28 \text { and November } 20 .\end{array}$ \\
\hline
\end{tabular}


AVO downgraded Cleveland to Color Code YELLOW 5 days later on February 11. Cloud cover persisted during most of this interval, and AVO's information release on February 11 noted that undetected, low-level unrest could continue. No further indication of activity led AVO to further downgrade Cleveland to a Color Code of "Not Assigned" on February 20. (AVO policy is that a volcano lacking seismic instrumentation cannot be known to be at background, and hence cannot be assigned a Color Code GREEN).

On May 5, AVO reported a thermal anomaly and continuous plume of volcanic gas from Cleveland. The plume was visible over the course of 6 hours but traveled only 48 $\mathrm{km}$ (30 mi) southwest of the volcano and appeared to be at a relatively low altitude and devoid of ash. Cleveland remained "Not Assigned."

On May 23, an astronaut aboard the International Space Station (ISS) contacted ground control with a report of an eruption from a volcano in the Aleutians. Subsequent communication with AVO, including receipt of a photograph (fig. 41) and a telephone call from the ISS, confirmed
Cleveland as the source. The plume was ash rich and by the time it was detected in AVHRR imagery, it was a detached ash cloud about $130 \mathrm{~km}$ (80 mi) southwest of the volcano. Satellite cloud-temperature data indicated a cloud top of about $6,700 \mathrm{~m}$ $(22,000 \mathrm{ft})$ ASL. AVO raised the Level of Concern Color Code for Cleveland to YELLOW, and subsequently downgraded to "Not Assigned" on May 26 after no further activity was detected.

On August 24, AVO received notice from NWS that a ship had reported an ash eruption from Cleveland volcano. Days later, AVO received video footage from the crew of this fishing vessel showing a definite ash plume reaching about $3 \mathrm{~km}(\sim 10,000 \mathrm{ft})$ ASL (fig. 42). Importantly, neither a broadband regional network seismic station in Nikolski (fig. 1; M. West, UAFGI, written commun., 2006) nor any timecorrelative satellite imagery showed evidence of this eruption. On September 7, after reviewing video footage of the August 24 event and noting an intermittently present thermal anomaly at the volcano, AVO raised the Level of Concern Color Code to YELLOW.

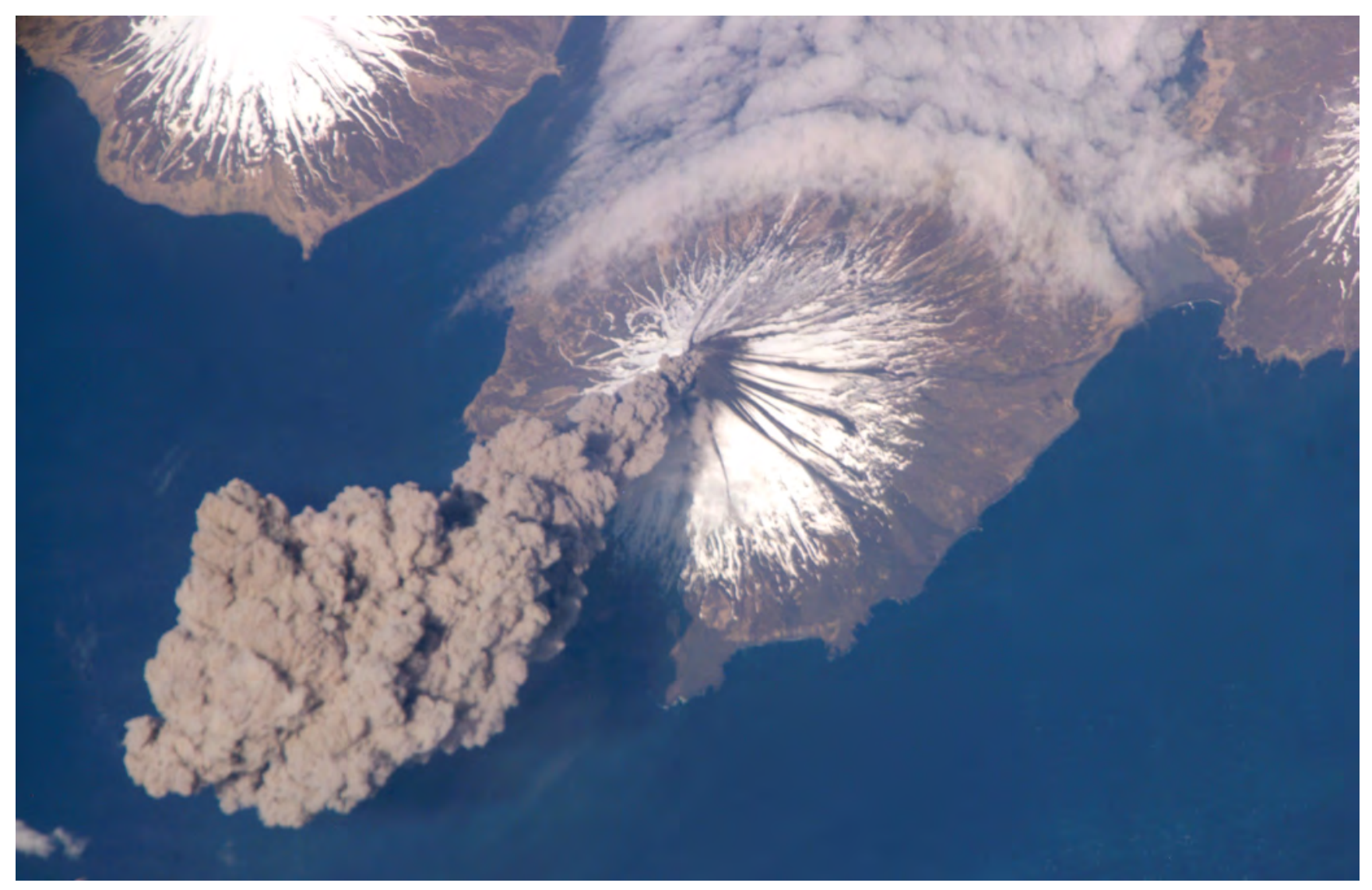

Figure 41. Eruption cloud from Cleveland volcano as seen from the International Space Station, May 23, 2006. North is at the top. The lower slopes of Carlisle Volcano are visible northwest of erupting Cleveland. To our knowledge, this represents the first time that an eruption in Alaska has ever been first spotted by an astronaut who reported the event to ground control. Image courtesy of Image Science and Analysis Laboratory, NASA-Johnson Space Center. 
AVO was alerted by NWS of another Cleveland eruption on October 28 after a pilot report to the Anchorage Air Traffic Control Center. The pilot of a jetliner indicated an initial cloud over the volcano reaching their flight level of $36,000 \mathrm{ft}$ $(11,000 \mathrm{~m}) \mathrm{ASL}$, and a drifting cloud moving east-northeast at a lower level of 30,000 ft $(9,100 \mathrm{~m})$ ASL. Satellite-derived cloud top temperature estimates placed the plume much lower. Utilizing the new warning scheme adopted by United States Volcano Observatories in October, AVO declared Aviation Color Code ORANGE and Volcanic Activity Alert Level WATCH for Cleveland about 2 hours after receipt of the pilot report, and reverted to YELLOW/ADVISORY on October 30 after no indications of further activity. On clear days under optimal satellite viewing conditions, a weak thermal anomaly was detected in the vicinity of the summit crater at Cleveland into November (fig. 43).

Ash explosions likely occurred more often at Cleveland than were detected in either satellite imagery or by pilots or other observers. An infrasonic signal received at the Geophysical Institute in Fairbanks on November 6 may have been produced by an explosion at Cleveland (or a nearby volcano); however, with no corroborating evidence, AVO took no action (S.R. McNutt, UAFGI, written commun., 2006). A summary of 2006 explosions and other key observations of Cleveland over the course of the year is presented in table 8 . AVO tracked and responded to Cleveland activity in 2006 by relying heavily on remote sensing of the volcano and rapid response to reports received from pilots or other sources. Automatic PUFF runs of hypothetical ash trajectories appeared on the PUFF web site at URL: http://puff.images. alaska.edu/monitoring.shtml. The NWS issued SIGMETs as required for each detected cloud. Air-traffic disruptions were minimal.

Cleveland volcano forms the western portion of Chuginadak Island, an uninhabited island in the east-central Aleutians. Cleveland is located about $75 \mathrm{~km}(45 \mathrm{mi})$ west of the community of Nikolski, and 1,500 km (940 mi) southwest of Anchorage. Historical eruptions have been characterized by short-lived ash explosions, lava fountaining, lava flows, and pyroclastic avalanches down the flanks. In February 2001, three explosive events produced ash clouds as high as $12 \mathrm{~km}$ $(39,000 \mathrm{ft})$ ASL (Dean and others, 2004), a rubbly lava flow, and a hot avalanche that reached the sea.

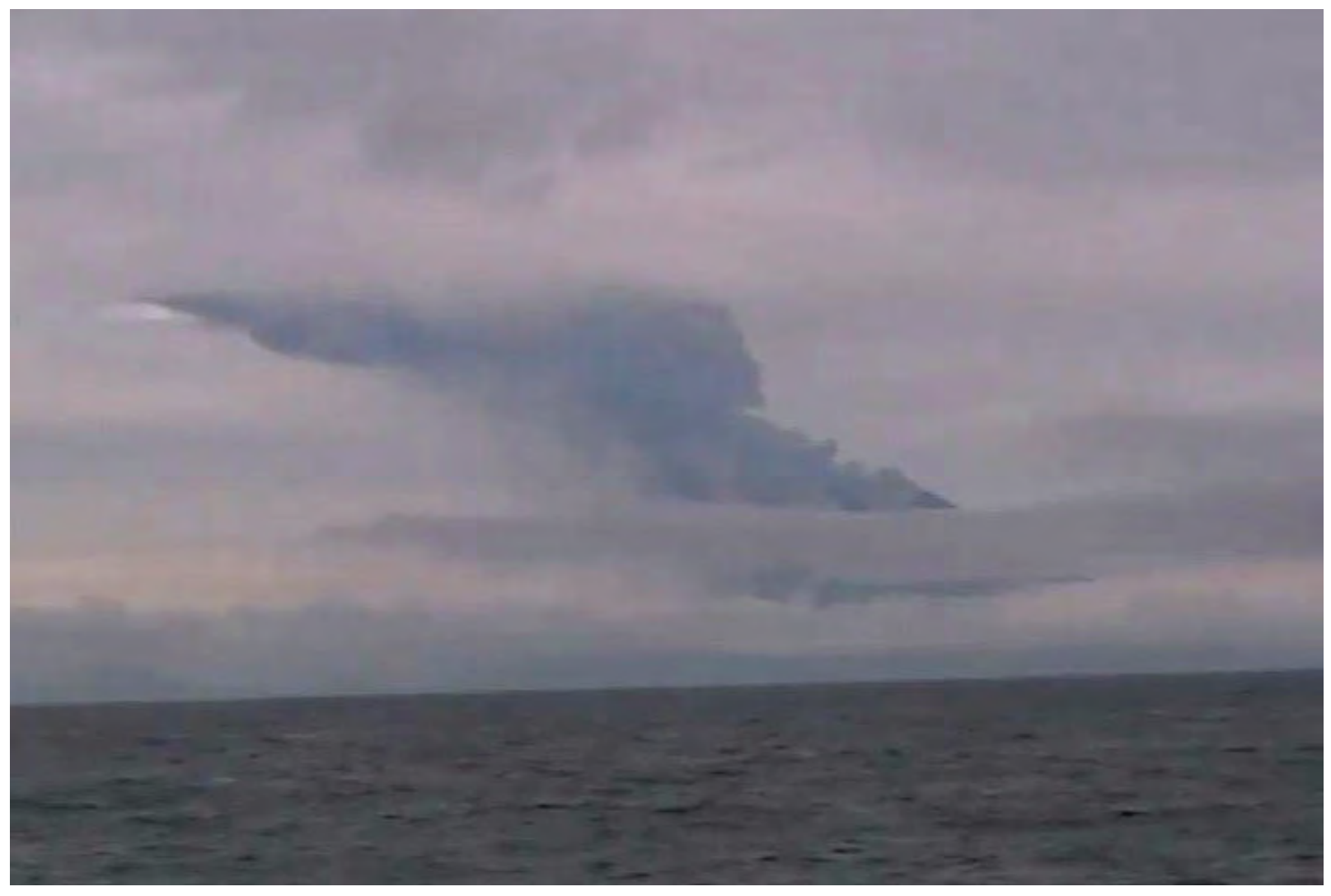

Figure 42. Video frame grab of an eruption in progress at Cleveland volcano, August 24, 2006. This video footage was shared by the crew of the F/V Shady Lady (Jane and Dan VeerHeusen and Jack Ness). The Shady Lady was passing by Cleveland when the eruption occurred. They estimated the height of the ash cloud to be about 10,000 $\mathrm{ft} \mathrm{ASL}$. The eruption was brief, lasting only minutes. AVO database image at URL: http://www.avo.alaska.edu/image.php?id=11003. 

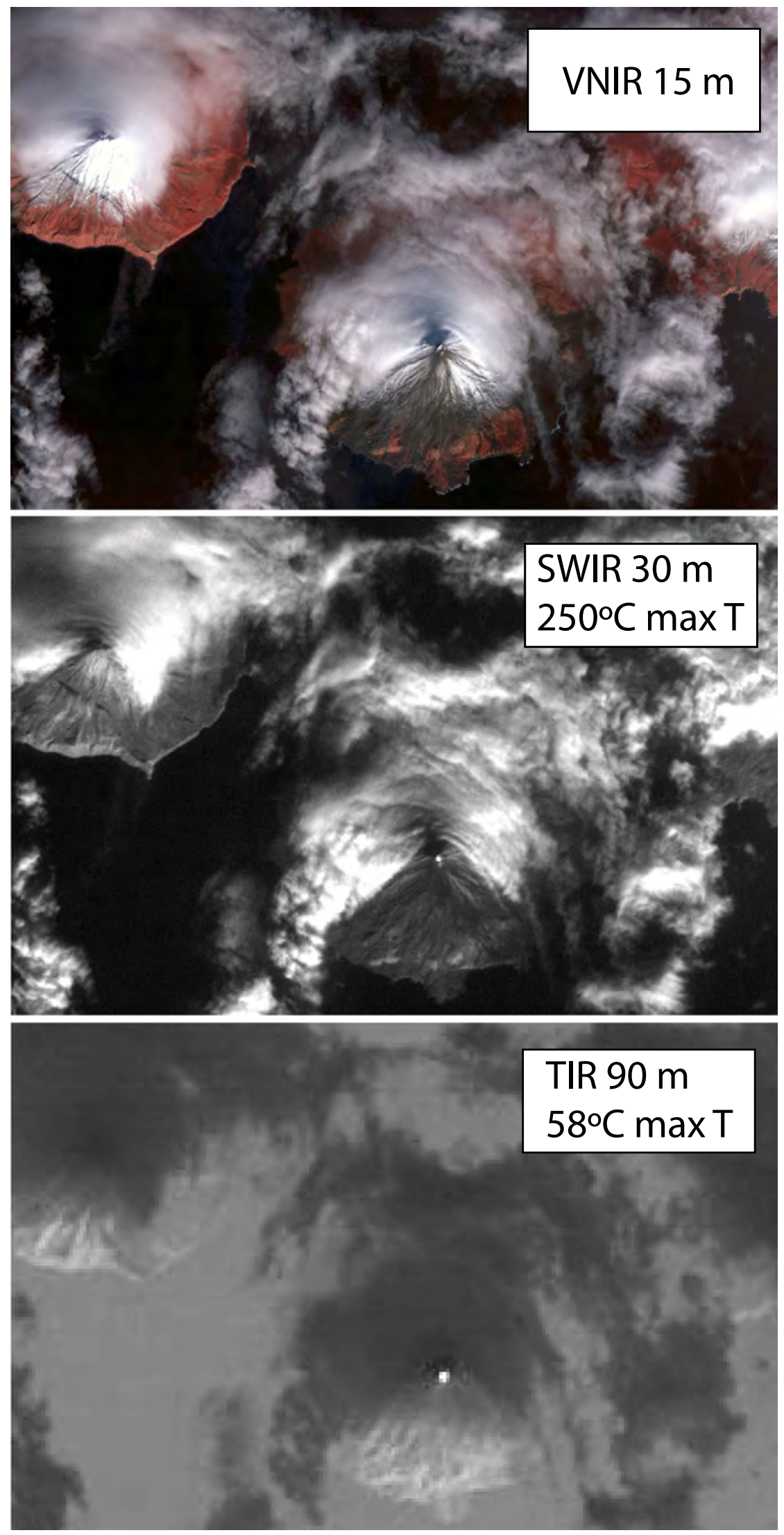

Figure 43. Collection of daytime thermal images of Cleveland taken by the Advanced Spaceborne Thermal Emission and Reflection Radiometer (ASTER) sensor at 22:35 UTC on November 4, 2006. Note cluster of white pixels indicating hightemperature area in the summit crater (Short Wave Infrared [SWIR] and Thermal Infrared [TIR] images at middle and bottom) and dark deposits on the south flank (Very Near Infrared [VNIR] image at top). Pixel resolution indicated on each frame. The age of the deposits in the VNIR image is not known but may represent activity in late October. Image compilation by R.L. Wessels, AVO/USGS. 


\title{
Korovin Volcano (Atka)
}

\author{
CAVW\# 1101-16
}

$52^{\circ} 23^{\prime} \mathrm{N} 174^{\circ} 10^{\prime} \mathrm{W}$

$1,533 \mathrm{~m}(5,030 \mathrm{ft})$

Atka Island, west-central Aleutian Islands SEISMIC SWARMS, TREMOR, UPLIFT, INCREASED FUMAROLIC ACTIVITY

Korovin volcano on Atka Island in the west-central Aleutians has been the site of relatively high background seismicity since the AVO network was installed in 2004. Beginning on January 16, a brief (minutes-long) increase over this background level was noted. Additional bursts of tremorlike signals occurred on January 17-18, 21, and February 21-22, prompting AVO to raise the Level of Concern Color Code to YELLOW. Satellite imagery of the volcano showed nothing unusual, although clouds frequently obscured the region. AVO did not receive reports of activity from residents of Atka Village, despite periods of clear weather in late February.

Seismicity stabilized and then decreased in early March, and AVO downgraded the Level of Concern Color Code to GREEN on March 8. Clear satellite looks and overflights by commercial pilots indicated no significant surface changes in the vicinity of Korovin. In the spring, there were several week-long outages where fewer than the minimum number of stations required to locate earthquakes were operational.

The number of earthquakes in the vicinity of Korovin began to increase again in July. Episodes of volcanic tremor were recorded again in September and October, increasing in number, strength, and duration into the fall. White plumes of water vapor reaching several hundred meters above the volcano were photographed from Atka on October 29 (fig. 44), about coincident in time with a strong tremor burst about 5 minutes in duration captured on the Korovin network. The shallow lake in the main Korovin crater, present on September 12 according to satellite data, had disappeared by October 19, and remained absent through the end of the year. On November 5, the strongest earthquake swarm ever recorded by the AVO seismic network occurred. AVO decided to upgrade the level of concern for Korovin, based on this sustained increase in seismic activity and visual confirmation of increased fumarolic activity and disappearance of the lake. Utilizing the new warning scheme adopted by the United States Volcano Observatories in October, AVO declared Aviation Color Code YELLOW and Volcanic Activity Alert Level ADVISORY for Korovin on November 6.
Seismicity at Korovin remained above background through the year's end. Periodic strong, short-duration (tens of seconds to several minutes) signals recorded on the entire network may have been phreatic explosions or sudden hydrothermal boiling events. Similarly, several-minutelong, low-frequency tremor bursts at rates of several per hour occurred intermittently. ASTER satellite images from November 18 indicated an exposure of dark-gray ash on the eastern flank of Korovin's main crater (fig. 45); this ash was not present in a similarly clear image from November 21. Still, it is not known exactly when and by what process ash was emitted from Korovin; it also is possible that the ash visible in satellite imagery represents remobilization of older ash high on the cone, as may have been photographed during fieldwork in 2004 (figs. 46 and 47). Thermal bands in ASTER imagery showed warm areas in the Korovin crater, not a surprise given the known, ongoing fumarolic activity within the crater (fig. 46).

In late November, AVO learned that the Korovin volcano area had undergone significant deformation during the second half of the year. InSAR results comparing data from July and October 2006 for Korovin indicated a very prominent, circular pattern of uplift of as much as $5 \mathrm{~cm}$ (2 in) centered about $5.5 \mathrm{~km}$ (3.4 mi) southwest of Korovin (fig. 48; Z. Lu and P. Cervelli, USGS, written commun., 2006). This location generally is consistent with locations of earthquake swarms beginning in the summer. Two possible explanations for this uplift were considered: (1) a pressurizing and inflating hydrothermal system, plausible given the robust, disseminated hot springs around Korovin and neighboring Kliuchef volcanoes (Motyka and others, 1993) or (2) a rising magmatic intrusion and related deformation.

Residents of Atka continued to photograph particularly large, at times 'puffing' white-vapor plumes emanating from Korovin on December 11, 21, and 24 (figs. 49 and $\underline{50}$ ). At least one of these reports suggested the possibility of ash within the plume; the observer further clarified that he saw ash falling below the cloud after it attained some altitude. Ash on the ground was not verified. Satellite data did not detect any rise in ground temperature nor any ash in the atmosphere or on the ground through the end of 2006. 


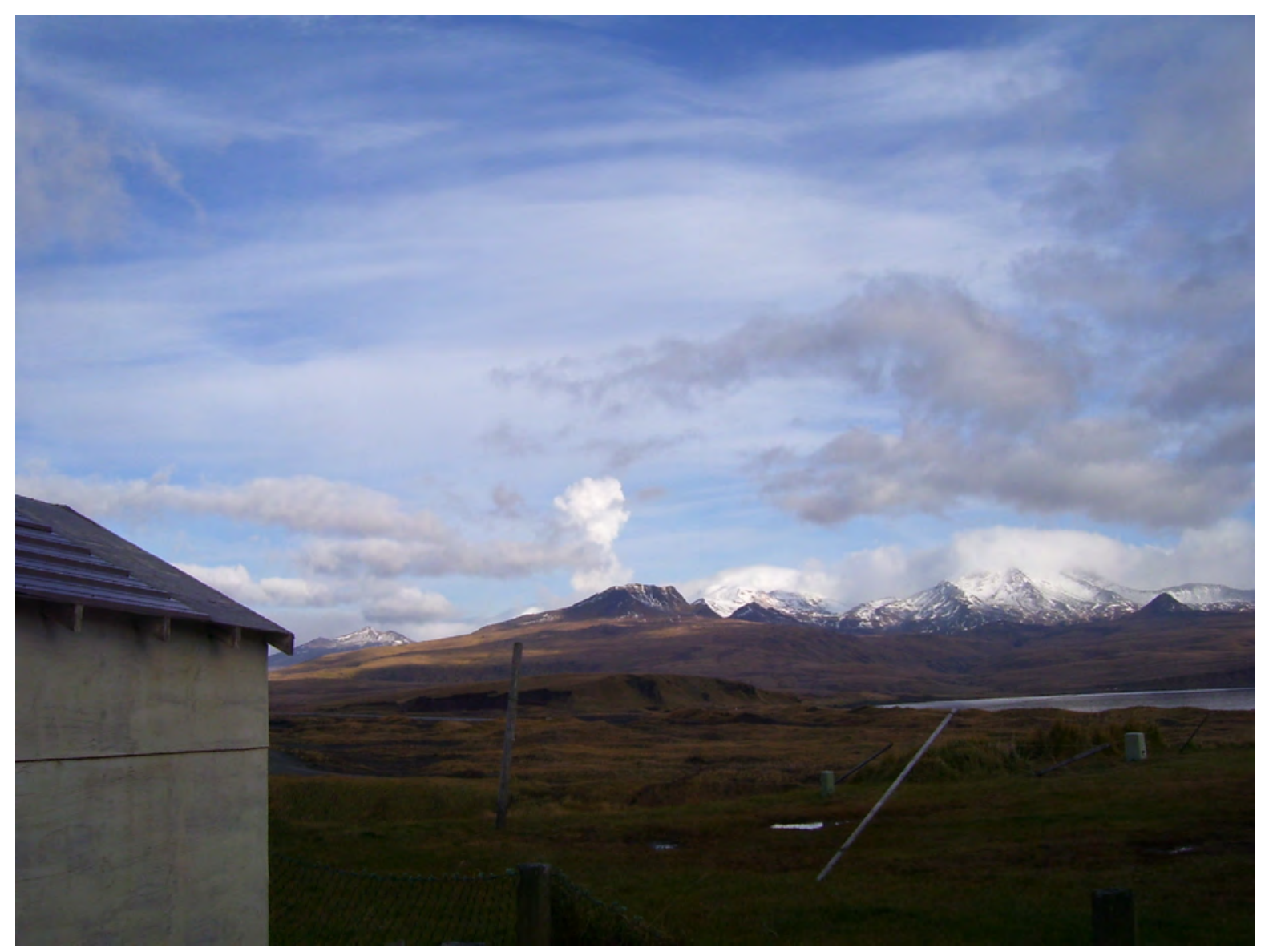

Figure 44. A vapor plume rises above the Korovin volcano summit crater, October 29, 2006. The actual summit of Korovin is obscured by topography. Photograph by L. Nevzeroff (used with permission) of Atka Village. 


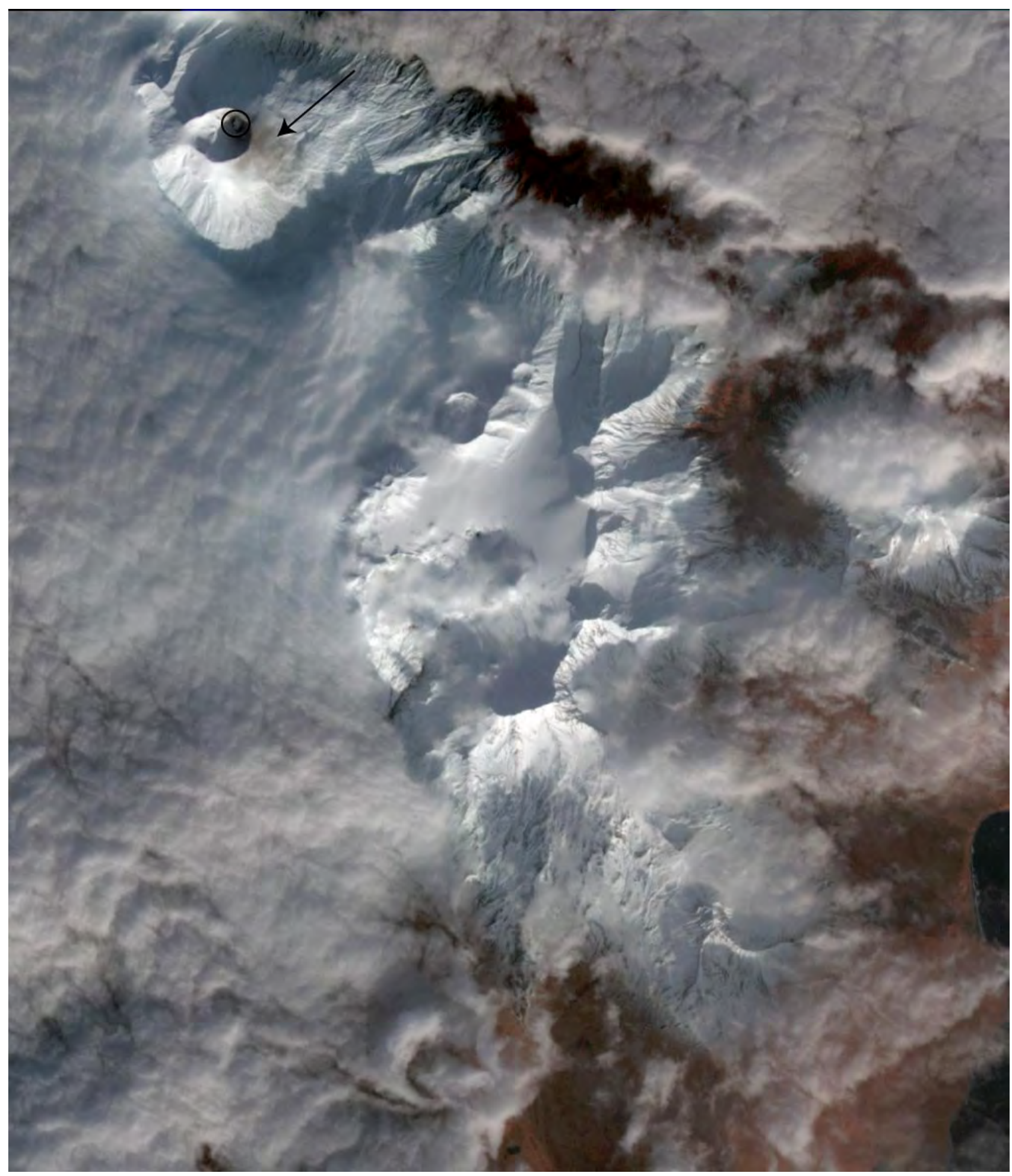

Figure 45. ASTER satellite image of a portion of Atka Island showing a fresh ash (?) deposit on the upper flank and crater rim of Korovin (upper left; arrow), November 18, 2006. Similar localized ash deposits have been seen in this sector on several occasions since 2004 (see figure 47). A small water-vapor plume is visible deep in the inner crater of Korovin (circle). Clouds obscure much of the terrain below the volcanic peaks. The partially visible crater to the lower right of Korovin is the summit of Kliuchef. ASTER satellite-image data courtesy of NASA/GSFC/METI/ERSDAC/JAROS, and U.S./Japan ASTER Science Team and R.L. Wessels, AVO/USGS. Image processed by AVO/USGS. 


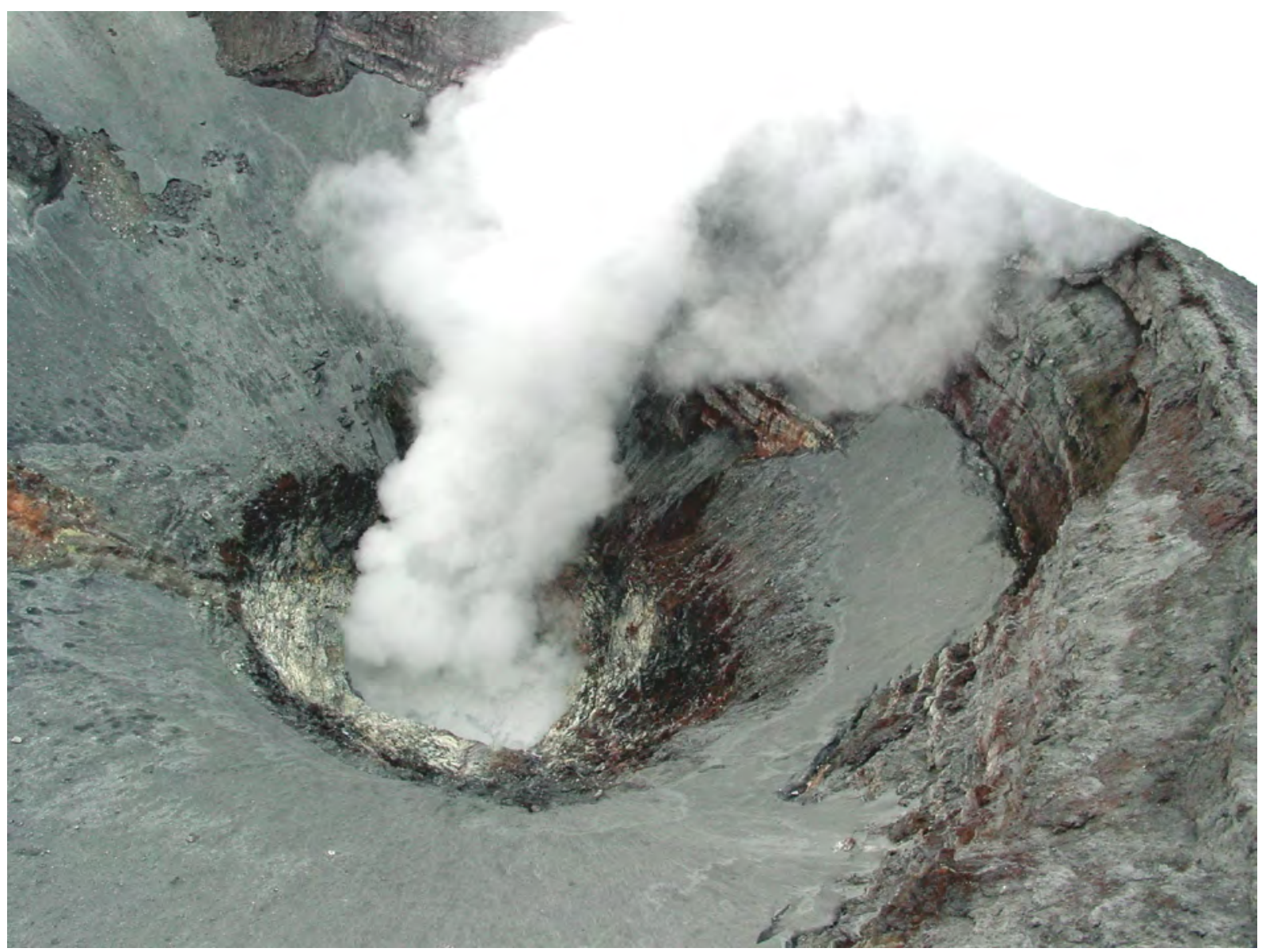

Figure 46. Aerial view into the summit crater of Korovin. This level of fumarolic emission from the slightly oblong, 60-90 m (200-300 ft) diameter, sheer-walled orifice at the bottom of the crater is apparently fairly typical and can account for the periodic observations of plumes from Atka Village. At times, a shallow body of gray, turbid water partially fills the inner crater and, in 2004, was observed roiling. Phreatic explosions from this water-rich, hightemperature system may be responsible for the occasional localized ash-fall deposits seen on the upper flanks of Korovin. Photograph by R.G. McGimsey, AVO/USGS, July 19, 2004. AVO database image at URL: http://www.avo.alaska. edu/image. php?id=12465. 


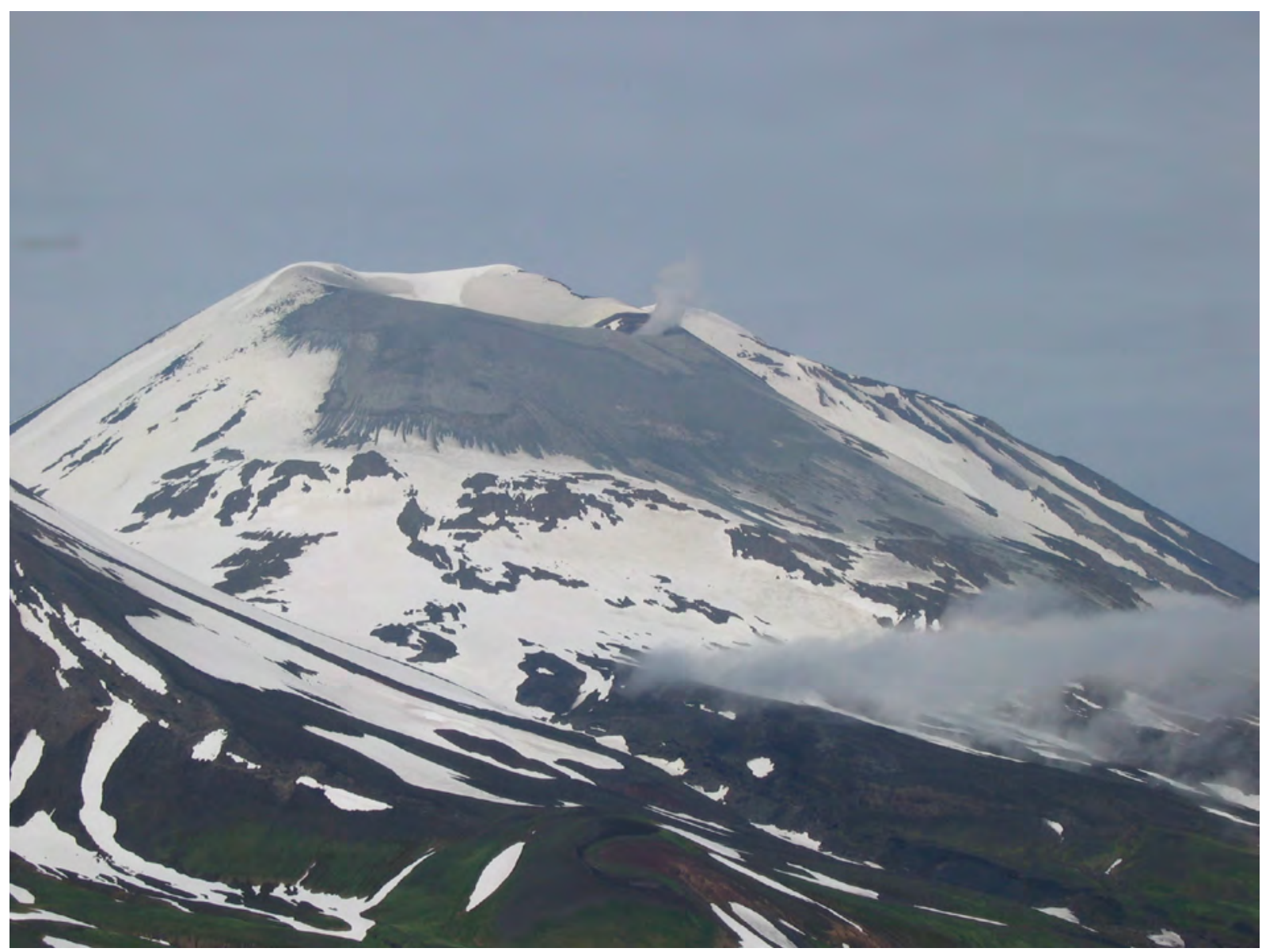

Figure 47. View of the east flank of Korovin volcano, July 7, 2004. Gray-ash deposit similar to that in the ASTER image in figure 45 clearly is visible atop the snow, although its significance is unclear. The deposit may be the result of phreatic explosions or vigorous wind remobilization of ash from within the summit crater. Photograph by T. Fournier (used with permission), UAFGI. AVO database image at URL: http://www.avo.alaska.edu/image.php?id=12526. 


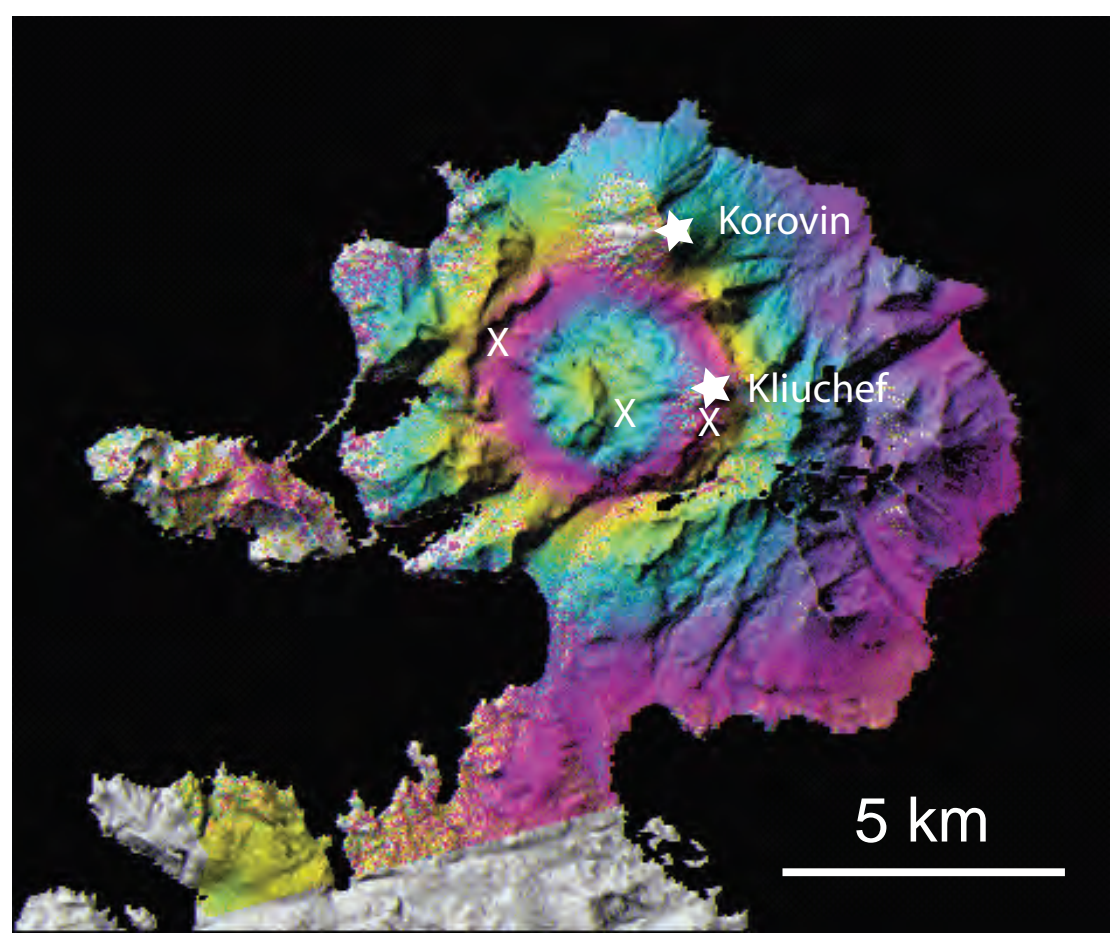

\section{range change}

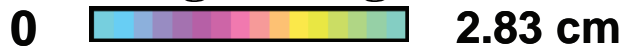

Figure 48. InSAR interferogram for the northern part of Atka Island showing the circular pattern of uplift that occurred during July through October 2006. Summits of young volcanoes Korovin and Kliuchef noted with stars. Approximate position of known thermal areas shown with "X" adapted from Motyka and others, 1993. Figure courtesy of Z. Lu, USGS.

AVO tracked activity at Korovin using seismic and satellite data. Several times during the year, AVO staff contacted Atka residents by telephone or email to gather additional observations or clarify AVO reports. In February, AVO asked Peninsula Airways (Pen Air) pilots flying into Atka to pass along any pertinent observations. On February 22 , Pen Air reported no sign of ash or anything unusual at the volcano.

Korovin volcano is $1,533 \mathrm{~m}(5,030 \mathrm{ft})$ ASL. This stratovolcano is on the northern part of Atka Island, about 184 $\mathrm{km}(110 \mathrm{mi})$ east of Adak, $540 \mathrm{~km}$ (330 mi) west of Dutch Harbor, and 1,760 km (1,100 mi) southwest of Anchorage. Korovin has two distinct summit craters, about $600 \mathrm{~m}$ $(2,000 \mathrm{ft})$ apart, that have been the sites of eruptive activity as recently as June 1998; reported heights of the ash plume produced by the 1998 eruption ranged from 4,900 to 9,200 $\mathrm{m}$ (from 16,000 to 30,000 ft) ASL (Neal and others, 2003). The most recently active of the craters hosts a small, roiling lake that occasionally produces energetic steam emissions. Thermal springs and fumaroles are on and near Korovin and nearby Kiuchef (fig. 51). Korovin has erupted several times historically; known events occurred in 1907, 1951, 1953, 1954, 1973, 1976, 1986, 1987, 1996, and 1998 (Miller and others, 1998). All these eruptions produced minor amounts of ash and one (1973) produced a small lava flow. Periods of increased seismicity, such as that which occurred in early 2006 appears to be common at Korovin, perhaps in response to its very active hydrothermal system (Motyka and others, 1993). 


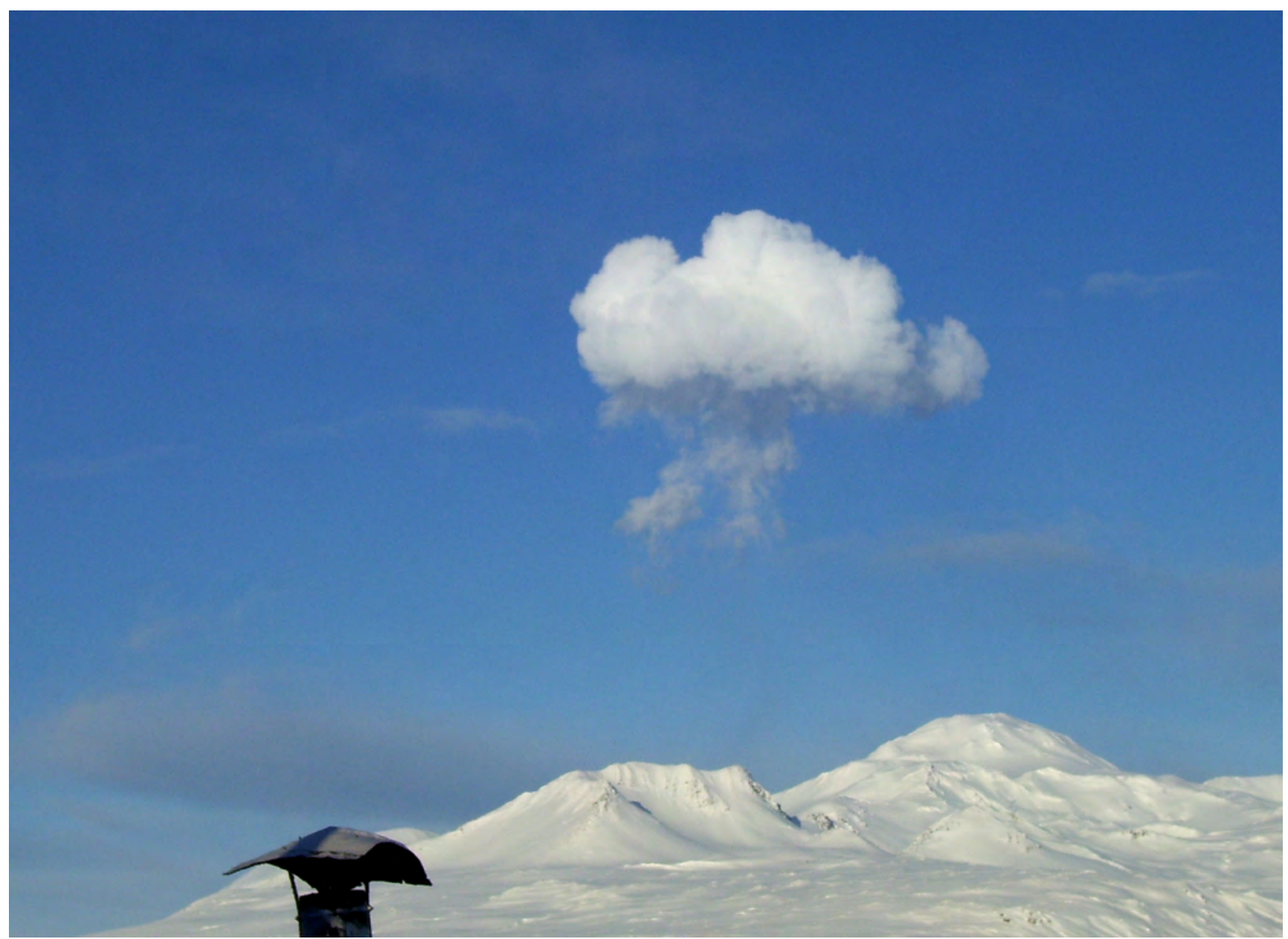

Figure 49. A puff of vapor rises above the Korovin summit crater, December 21, 2006. The actual Korovin summit is obscured by topography. The prominent peak to the right of the cloud on the skyline is Kliuchef. Photograph by L. Nevzeroff (used with permission) of Atka Village.

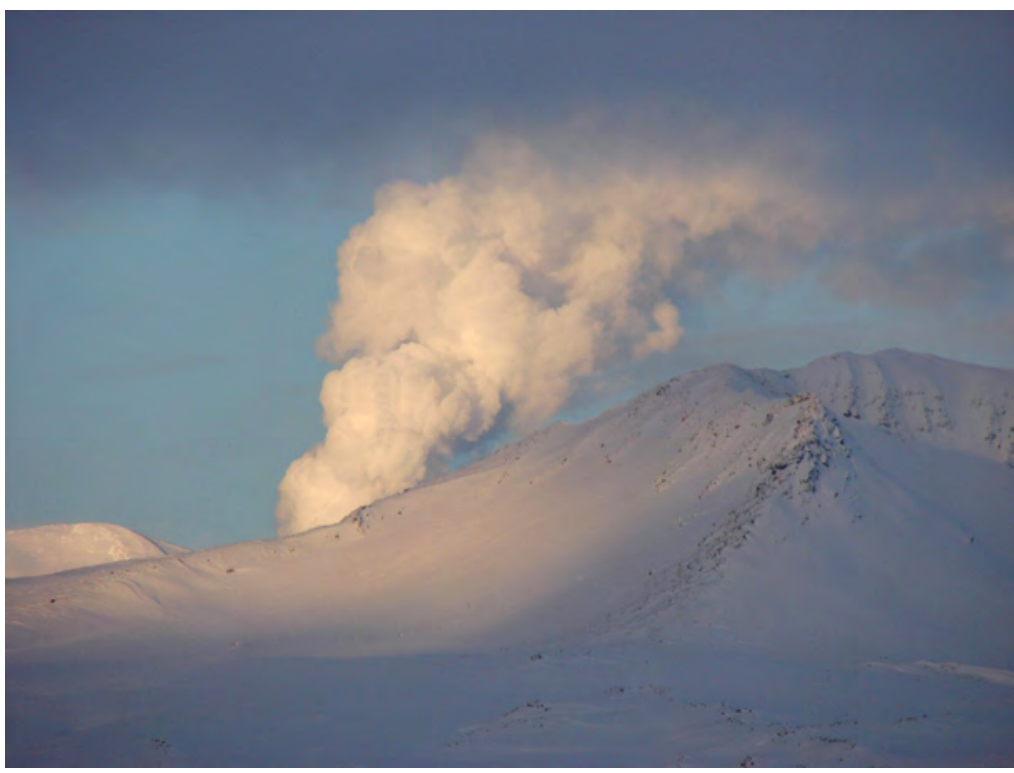

Figure 50. Telephoto image showing a robust, continuous plume of water vapor rises from Korovin volcano, December 24, 2006. Telephoto image taken by Lynne Moore (used with permission) of Atka Village. 


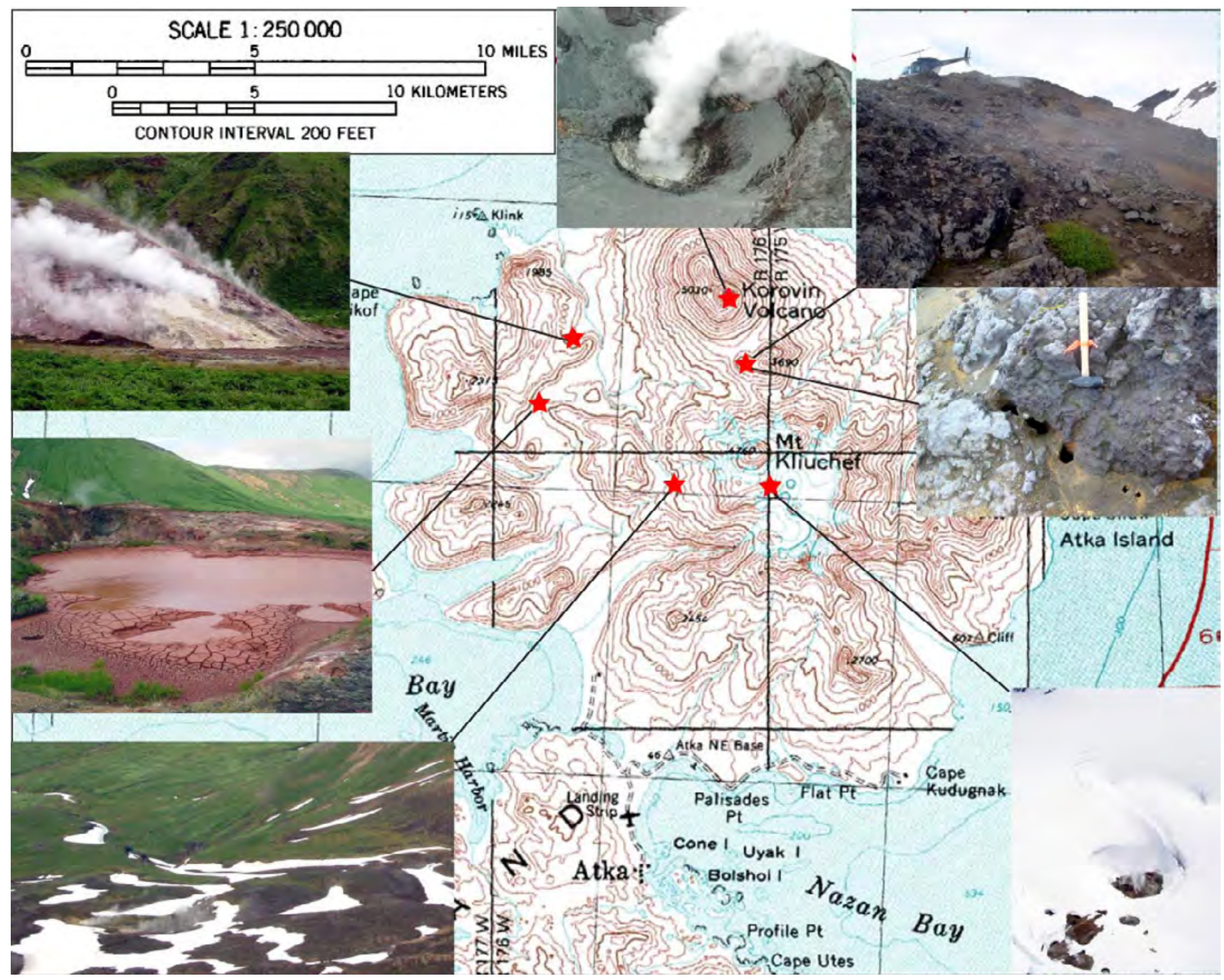

Figure 51. Thermal areas on north Atka Island based on fieldwork in 2004. 


\section{Kasatochi Volcano}

CAVW\# 1101-13

$52^{\circ} 10^{\prime} \mathrm{N} 175^{\circ} 31^{\prime} \mathrm{W}$

$314 \mathrm{~m}(1,030 \mathrm{ft})$

Kasatochi Island, west-central Aleutian Islands

VOLCANIC DEGASSING (?) Change in crater lake activity

Bubbling from the Kasatochi crater lake was first reported in the summer of 2005 (McGimsey and others, 2007) and continued into 2006. U.S. Fish and Wildlife Service (USFWS) scientist Brie Drummond, who has spent several summers on the island and was the principal observer of the 2005 activity, visited the south caldera rim on the morning of June 2, 2006. The day was overcast but calm and the lake surface was 'like glass.' Drummond noted a disturbance on the water surface on the west side of the lake, easily visible with the naked eye and very similar to what she had seen in 2005. The disturbance was in the same sector of the lake as in 2005 although perhaps smaller in area (figs. 52 and $\underline{53}$ ).
She described it as similar to 'rain falling onto a smooth lake surface.' However, in the absence of rain, it probably was a gentle effervescence. The spot on the lake surface was too far from the sheer rock walls to be explained by falling debris disturbing the water, and no birds or other biological activity were observed on the lake to account for the phenomenon.

Drummond described the bubbling as patchy with variable concentrations of bubbles, some occurring almost in a straight line. The bubbling was rapid and did not appear to change markedly over the course of 30 minutes of observation. As in 2005, Drummond noted no steam, no smell or odd discoloration of the water; gulls floated on the far side of

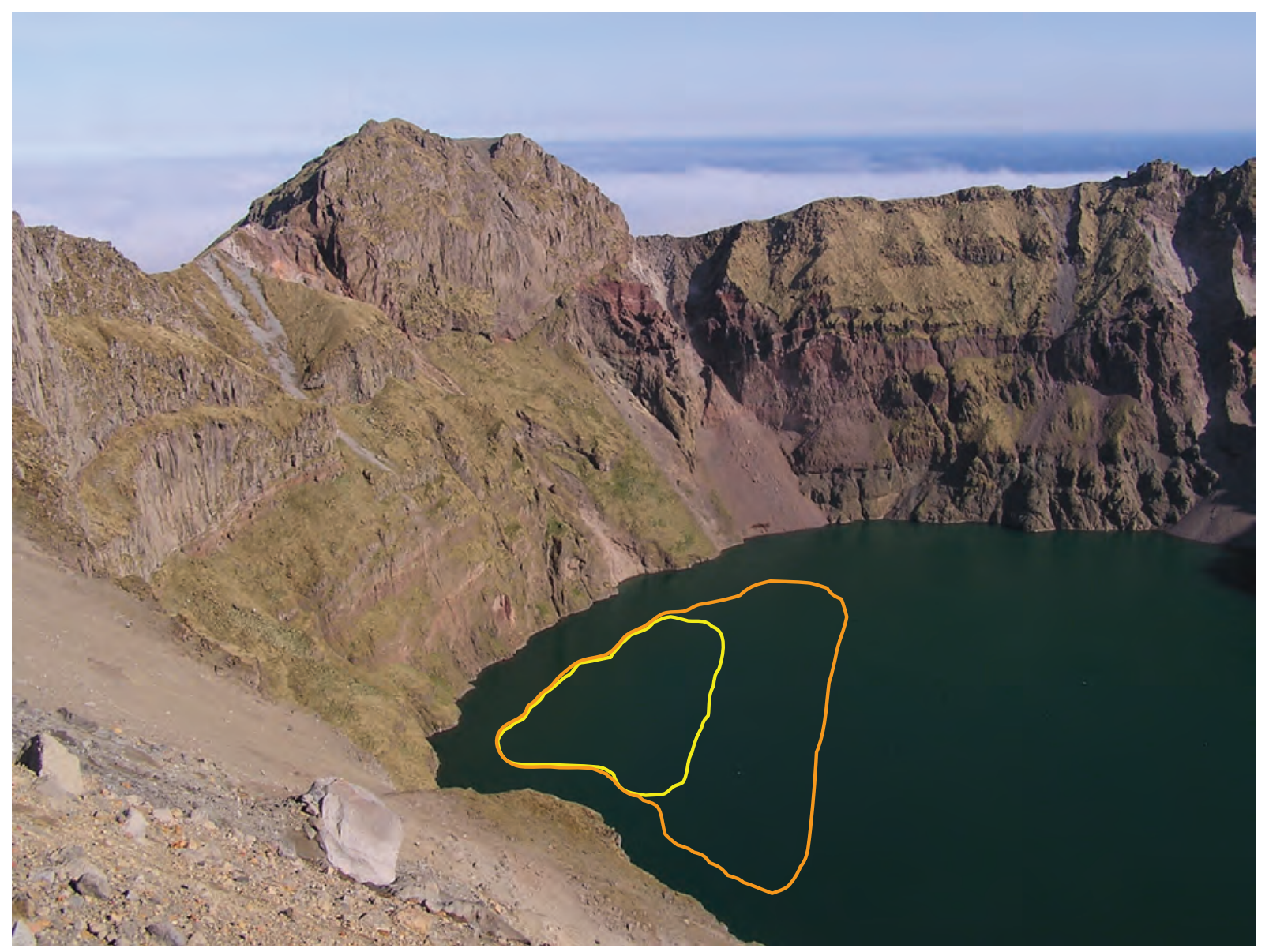

Figure 52. View of the lake at Kasatochi from the south rim of the caldera, May 26, 2006. Colored lines enclose the approximate area of the lake surface observed bubbling in 2005 (orange) and 2006 (yellow). Photograph and annotation by Brie Drummond, USFWS. 


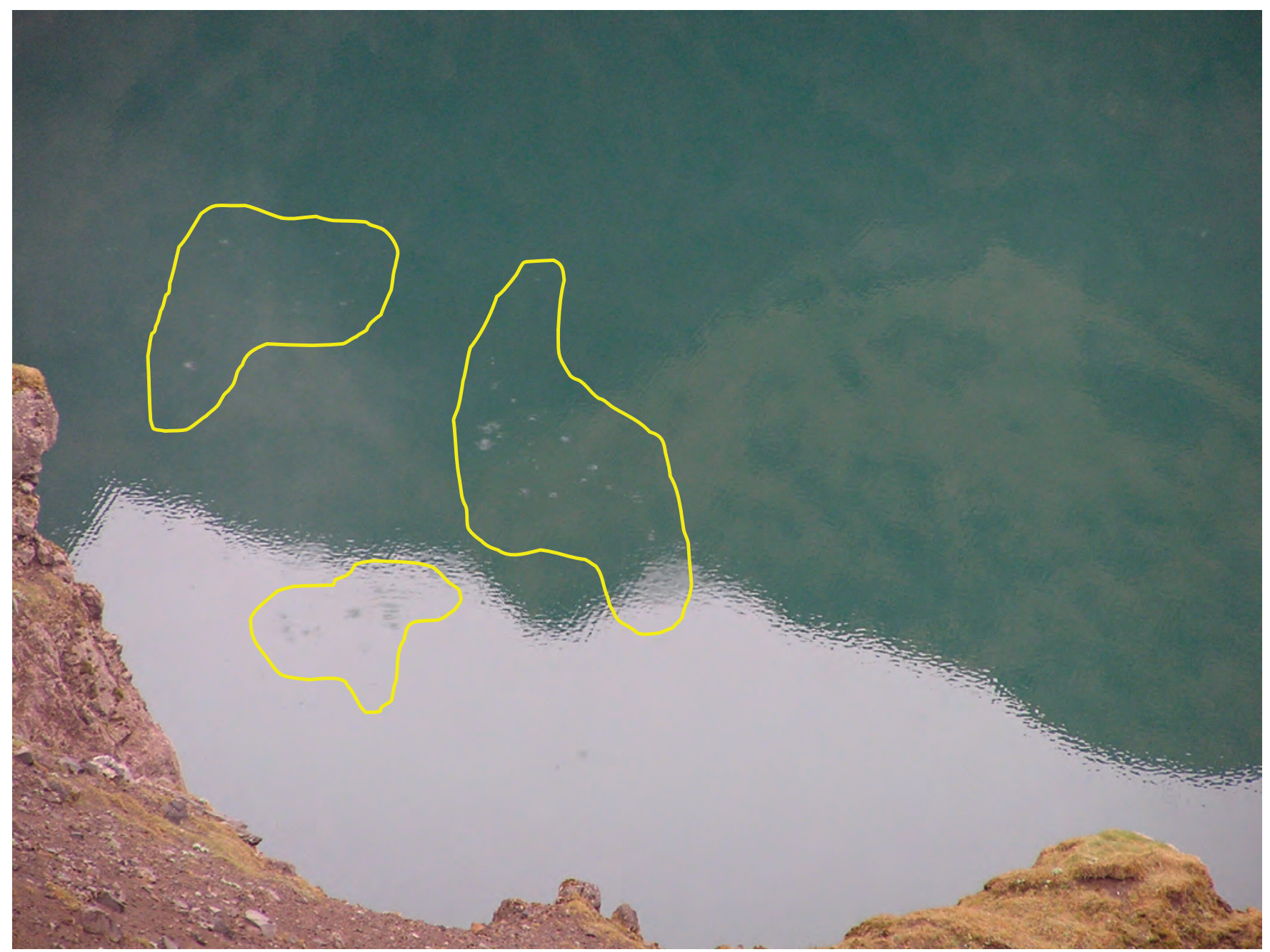

Figure 53. Telephoto view of the lake at Kasatochi from the south rim of the caldera, June 2, 2006. Yellow lines enclose areas of most prominent bubbling or effervescing in 2006. Other less concentrated bubble clusters are not visible in this photograph. The rim of the caldera is about $330 \mathrm{~m}(1,100 \mathrm{ft})$ above the surface of the lake at this point. Photograph by Brie Drummond, USFWS.

the lake. On a windy day a week prior (May 26, 2006), Drummond's field party did not see the bubbling, but it may well have been masked by the strong surface wave action due to high winds. Based on Drummond's sketch, the bubbling zone in 2006 was about 100-200 $\mathrm{m}(\sim 330-660 \mathrm{ft})$ across (figs. 52 and $\underline{53}$ ).

Sampling of lake water was logistically impossible due to difficult, hazardous access, and we have no direct analyses of water or the gas phase to investigate the source of the bubbling. USGS chemist Bill Evans (written commun., 2007) prefers magmatic or hydrothermal processes to explain the bubbling observed in this young volcanic crater lake based on the apparent high flux, the scarcity of vegetation on the crater walls to provide a source for organic decomposition, and the very localized nature of the bubbling areas. The youthfulness of this crater would be consistent with ongoing fumarolic activity that now is submerged. Trains of bubbles rising vertically from subaqueous-gas vents are common at similar volcanic lake settings such as at Mount Spurr and Gas Rocks. The apparent intermittent nature of the bubbling 


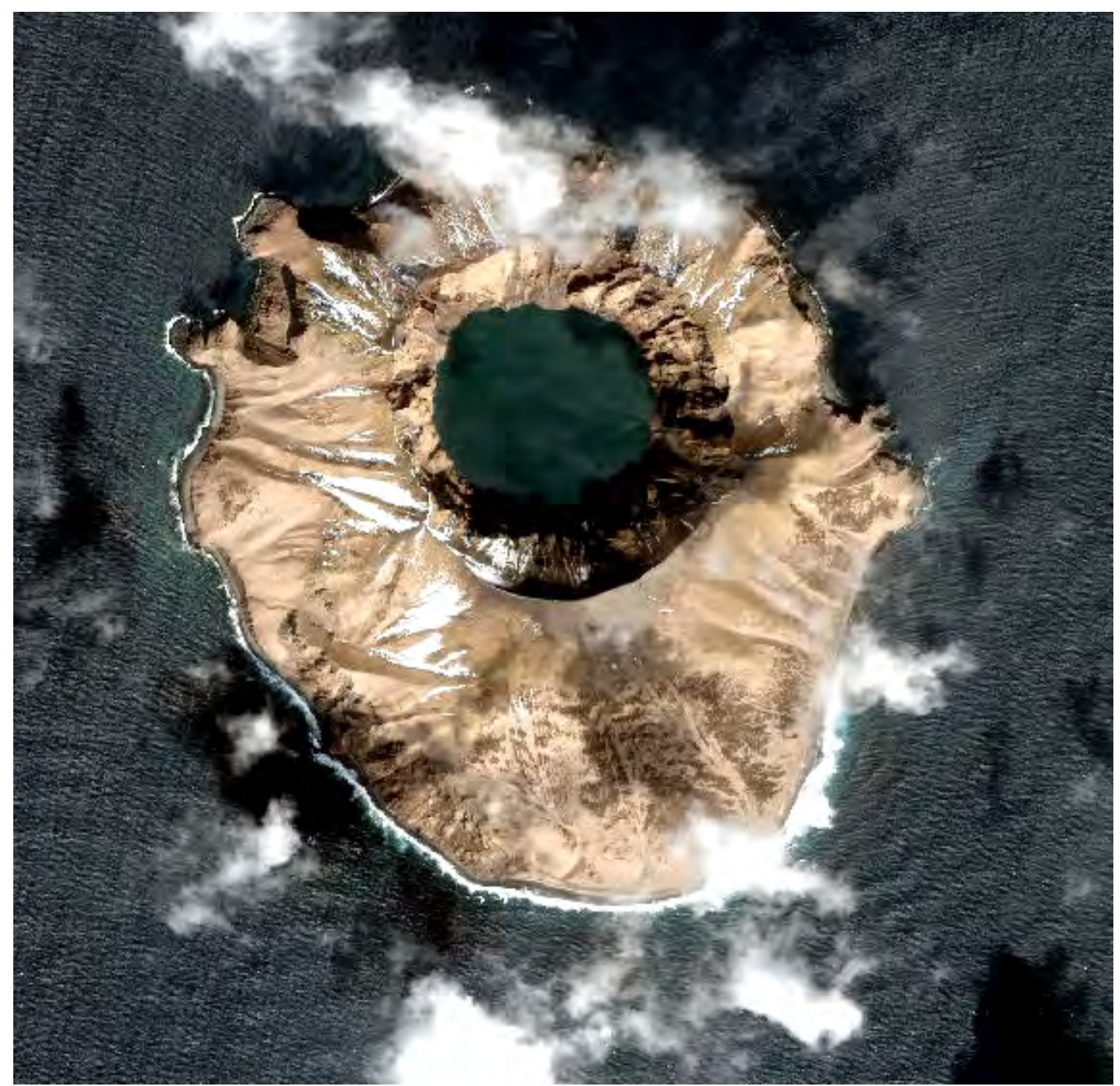

Figure 54. QuickBird satellite image of Kasatochi volcano taken at 22:45:59 UTC on April 9, 2004. North is at the top. Image 771030_01_P001. Copyright Digital Globe, 2004.

simply may reflect a strong dependence on meteorological conditions favorable to viewing or some seasonal variability depending on water depth. Another possibility put forth by Evans proposes degassing of a volatile-enrich, deeper water layer during disturbance of a salinity-controlled stratified water column.

Kasatochi Island is the exposed summit of a remote 400-m-high (1,300 ft) volcano formed atop the northern end of a $15-\mathrm{km}$ (9-mi) long, 6-km (4-mi) wide submarine ridge in the central Aleutians about $840 \mathrm{~km}(\sim 522 \mathrm{mi})$ west-southwest from the tip of the Alaska Peninsula. The island measures about $2.6 \times 3 \mathrm{~km}(1.6 \times 2 \mathrm{mi})$ and has a central lake-filled summit crater about $0.8 \mathrm{~km}(0.5 \mathrm{mi})$ in diameter (figs. 54 and 55). The surface of the lake was estimated to be about $50 \mathrm{ft}$ (15 m) ASL in 2005 using the helicopter's radar altimeter. The record of historical eruptive activity is poorly known. The island was reported as "emerging" in 1760 by Grewingk (cited in Miller and others, 1998) and as "smoking" in 1827 and 1828. USFWS observers reported 'increased steaming' at Kasatochi volcano following a 6.0 magnitude earthquake in June 1996 (Neal and McGimsey, 1997); however, the exact location of steaming is not recorded. 


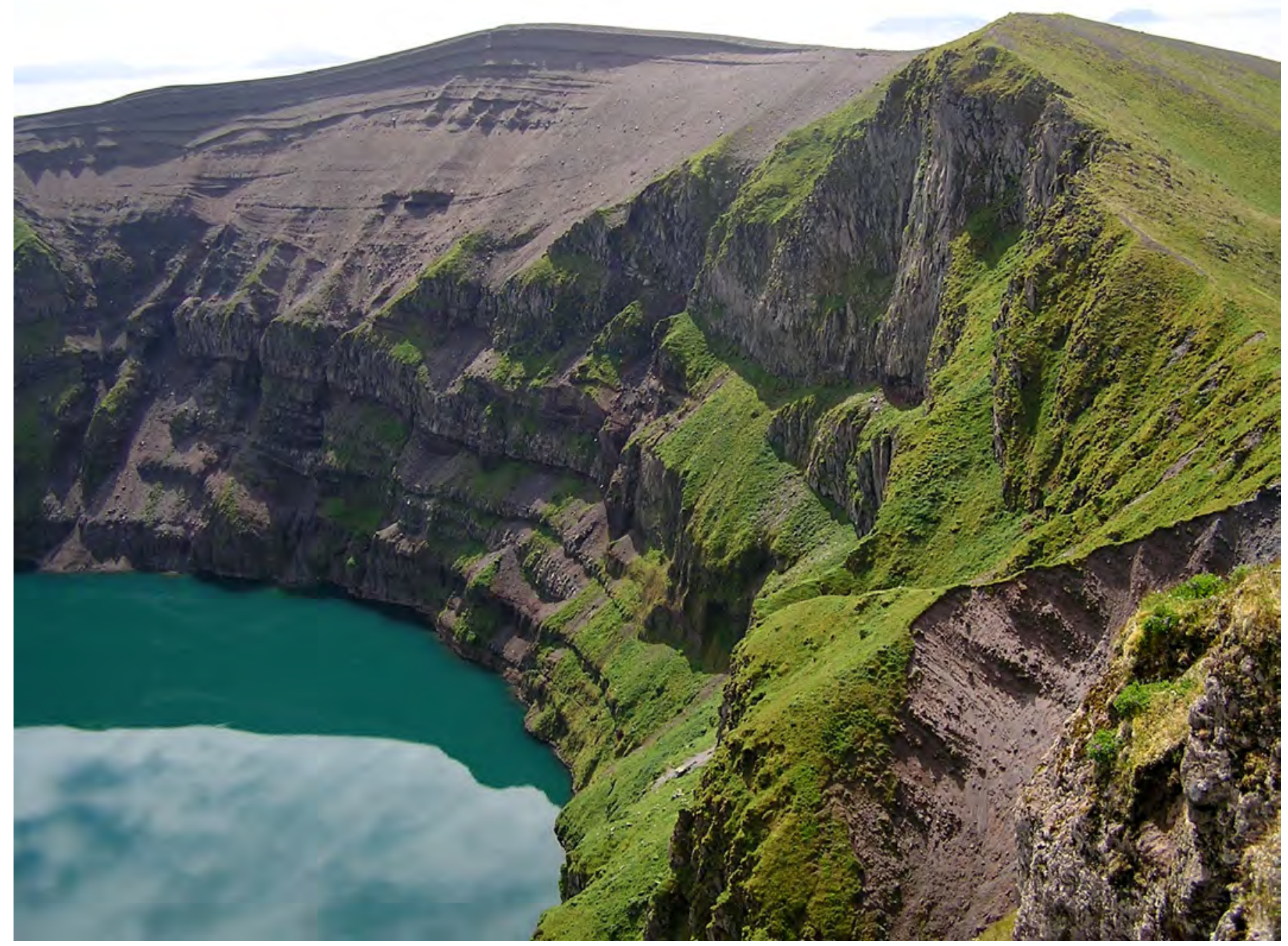

Figure 55. View towards the southeast from the rim of the lake-filled summit crater of Kasatochi volcano, August 3, 2004. Young (possibly historical in age), grey, pyroclastic deposits likely from the caldera-forming eruption cap the southern rim. Photograph by Brie Drummond, USFWS. 


\section{Volcanic Activity, Kamchatka Peninsula, and the Northern Kurile Islands, Russia}

Active volcanoes on Russia's Kamchatka Peninsula pose a serious threat to aircraft in the North Pacific, especially for planes on the North Pacific, Russian Trans-East, and CrossPolar routes. For this reason, AVO plays an ongoing role in satellite monitoring and dissemination of hazard information regarding Kamchatkan eruptions. AVO's responsibilities are codified in an annual operational agreement signed by the AVO Scientist in Charge and the Directors of the two institutes that comprise KVERT - the Institute of Volcanology and Seismology (IVS) and the Kamchatkan Branch of Geophysical Surveys (KBGS; formerly the Kamchatkan Experimental and Methodical Seismological Department [KEMSD]).
Scientists affiliated with KVERT monitor 11 of the most frequently active volcanoes in Kamchatka and on the north Kurile Islands of Paramushir and Atlasova with one or more short-period seismometers (fig. 56; table 9). In addition, they receive visual reports of volcanic activity from scientific observers in the communities of Severo-Kurilsk (population 2,000-3,000, 7 km [4 mi] east of Ebeko); Klyuchi (population 6,000-7,000, $46 \mathrm{~km}$ [29 mi] south of Sheveluch); and Kozyrevsk (population 2,000-3,000, $50 \mathrm{~km}$ [31 mi] west of Klyuchevskoy) to the north and west of the Klyuchevskaya group of volcanoes. This group consists of active volcanoesKlyuchevskoy, Bezymianny, Plosky Tolbachik, Ushkovsky, and inactive volcanoes-Kamen, Krestovsky, Sredny, Ostry Tolbachik, Bolshaya Udina, Malaya Udina, Ostraya Zimina, Ovalnaya Zimina, and Gorny Zub (O.A. Girina, KVERT, written commun., 2004). KVERT also receives occasional reports from scientific field parties near Karymsky Volcano, and pilot reports are increasingly available from the local Civil

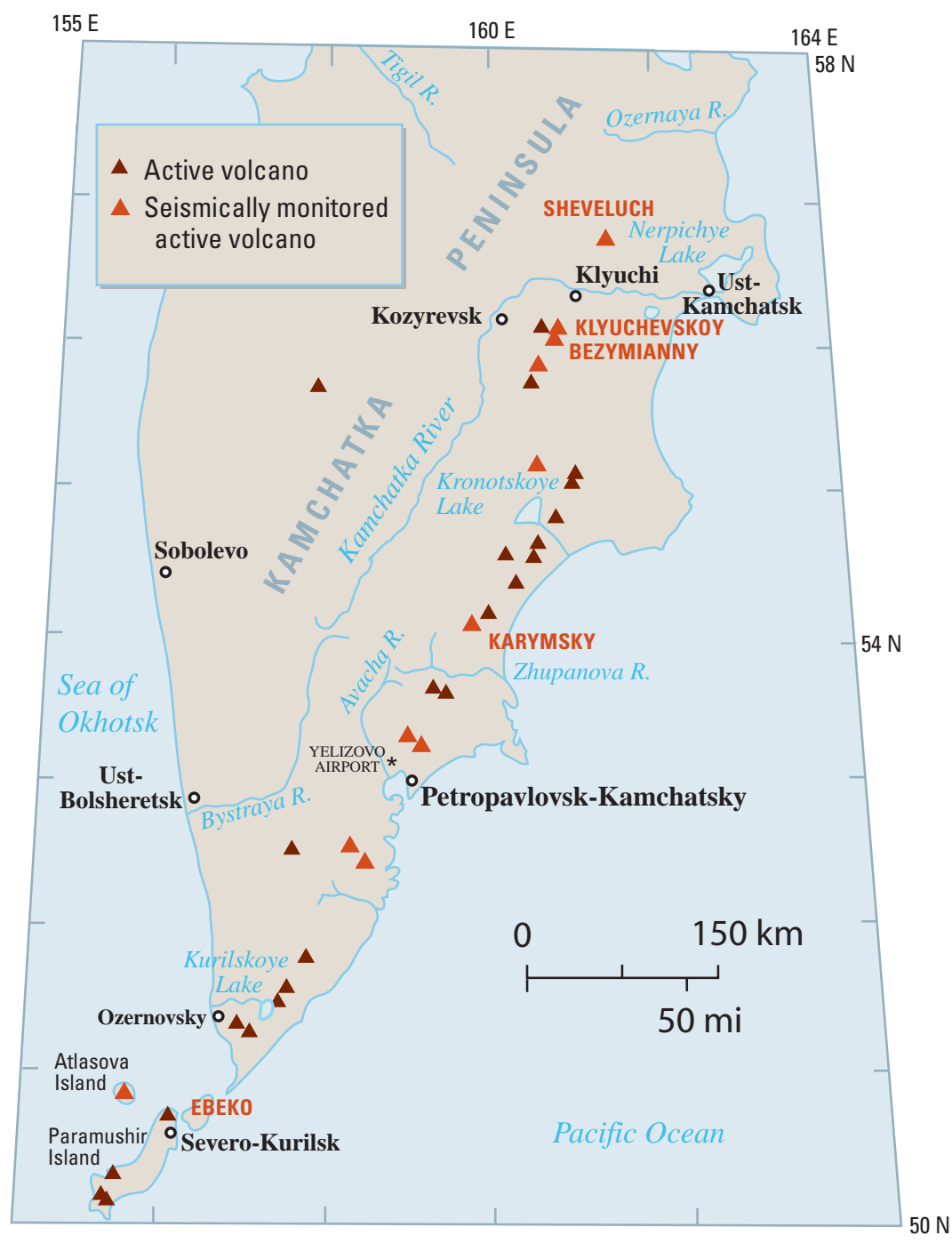

Figure 56. Kamchatka Peninsula and the northern Kurile Islands of Alaid and Paramushir. Volcanoes discussed in this report are labeled with bold red type. 
Table 9. Seismically monitored volcanoes of Kamchatka as of December 2006.

[Compiled by Sergey Senyukov, Kamchatka Branch of Geophysical Surveys (KBGS), and C.A. Neal, Alaska Volcano Observatory. Prior to 1979, other Russian scientific institutes maintained programs of volcano monitoring in Kamchatka (a partial listing includes: 1961-71, Pacific Seismological Department of Institute of Earth Physics; 1972-78, Institute of Volcanology). KEMSD, Russian Kamchatka Experimental and Methodical Seismology Department; PK, Petropavlovsk, capital city of Kamchatka, Russia]

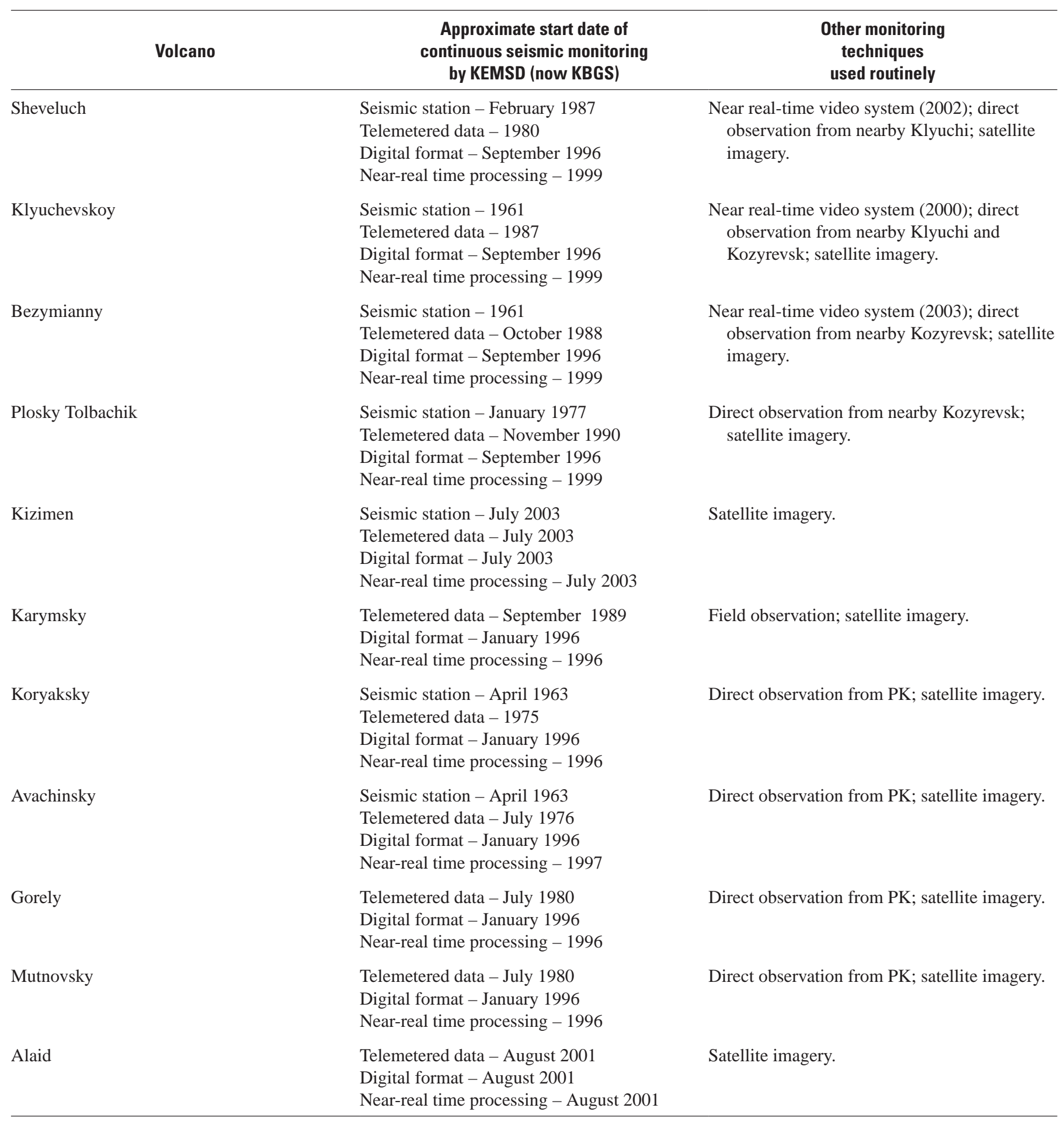


Aviation Meteorological Center at Yelizovo Airport. Near realtime, web-camera images of Sheveluch, Klyuchevskoy, and Bezymianny Volcanoes also are part of the routine monitoring data used by KVERT and AVO and many others. Summaries of volcanic activity and related color code changes for Russian volcanoes are listed in tables 10 and 11 .

KBGS scientists routinely retrieve and analyze National Oceanic and Atmospheric Administration (NOAA) 16 and 17 images in Petropavlovsk-Kamchatsky through an agreement between KBGS and Federal State Unitary Enterprise "Kamchatkan Center of Communication and Monitoring" that manages a NOAA receiving station. Beginning in 2006, KBGS scientists began determining temperature data from AVHRR data to evaluate thermal anomalies and estimate cloud heights by comparison to atmospheric profiles. KVERT also receives daily Satellite-based Moderate Resolution Imaging Spectroradiometer (MODIS) images from colleagues at the Russian Geological Fund (formerly the Far East Geological Information Center) of the Ministry of Natural Resources in

Table 10. Summary of VOLCANIC ACTIVITY on Kamchatka Peninsula and in the Kurile Islands, Russia, 2006.

[Location of volcanoes shown in figures 56 and 68]

\begin{tabular}{|c|c|c|}
\hline Volcano & Date of Activity & Type of Activity \\
\hline Sheveluch & $\begin{array}{l}\text { Significant pulse of } \\
\text { activity in December }\end{array}$ & $\begin{array}{l}\text { Lava dome growth, short- } \\
\text { lived, explosive episodes, } \\
\text { pyroclastic flows, ash } \\
\text { clouds, localized ash fall. }\end{array}$ \\
\hline Klyuchevskoy & December & $\begin{array}{l}\text { Period of elevated seismicity, } \\
\text { reappearance of thermal } \\
\text { anomaly, no eruption. }\end{array}$ \\
\hline Bezymianny & $\begin{array}{l}\text { Intermittently } \\
\text { throughout the year; } \\
\text { two large explosions } \\
\text { on May } 9 \text { and } \\
\text { December } 24\end{array}$ & $\begin{array}{l}\text { Short-lived explosive } \\
\text { eruptions, pyroclastic flows, } \\
\text { ash fall. Periods of gas and } \\
\text { steam plume generation. }\end{array}$ \\
\hline Karymsky & $\begin{array}{l}\text { Intermittently } \\
\text { throughout the year }\end{array}$ & $\begin{array}{l}\text { Periods of increased } \\
\text { seismicity continuation of } \\
\text { low-level Vulcanian and } \\
\text { Strombolian explosions, } \\
\text { avalanches, degassing. }\end{array}$ \\
\hline Ebeko & January 2006 & $\begin{array}{l}\text { Increased fumarolic activity } \\
\text { and magmatic outgassing }\end{array}$ \\
\hline Severgin & August 2006 & $\begin{array}{l}\text { Possible small ash plume } \\
\text { related to fumarolic or } \\
\text { phreatic activity. }\end{array}$ \\
\hline Berga & November 2006 & Possible steam and gas plume. \\
\hline
\end{tabular}

Yuzhno-Sakhalinsk. AVO satellite monitoring reports include coverage of Kamchatkan volcanoes, and these twice-daily reports are shared with KVERT staff via email. If AVO is the first to detect Kamchatkan eruption clouds the aviation community is alerted and KVERT is contacted by telephone.

In 2006, four Kamchatkan volcanoes were active, with a flurry of explosive activity occurring in December. The following summaries contain reported events according to Kamchatkan local dates and Coordinated Universal Time (UTC), which equals ADT +8 hours and AST +9 hours. The equivalent local Kamchatkan time [herein referred to as Kamchatkan Daylight Time (KDT) or Kamchatkan Standard Time (KST)] is 21 hours ahead of Alaska. This compilation is derived from a number of sources including KVERT weekly updates, unpublished AVO internal files and documentation, Global Volcanism Program Volcanic Activity reports and other information available at URL: http://www.volcano.si.edu/ reports/index.cfm.

Table 11. Kamchatkan volcanoes with Color Code changes in 2006.

[Description of Level of Concern Color Codes is shown in appendix 1. Local times are only shown where Color Code changes were short-lived during rapidly evolving events. Dates are from the KVERT Information Release and reflect the date in Kamchatka]

\begin{tabular}{|l|l|}
\multicolumn{1}{c}{ Color Code } & \multicolumn{1}{c}{ SHEVELUCH } \\
\hline \multicolumn{2}{|c|}{ J change } \\
\hline YELLOW & January 1 - December 5 \\
\hline ORANGE & December 5 - December 26 \\
\hline RED & December 26 - December 28 \\
\hline ORANGE & December 28- December 31 \\
\hline \multicolumn{2}{|c|}{ KLYUCHEVSKOY } \\
\hline GREEN & January 1 - December 19 \\
\hline YELLOW & December 19 - December 31 \\
\hline \multicolumn{2}{|c|}{ BEZYMIANNY } \\
\hline YELLOW & January 1 - May 7 \\
\hline ORANGE & May 7 - May 9 \\
\hline RED & May 9 - May 10 1040 \\
\hline ORANGE & May 10 1040 - May 11 \\
\hline YELLOW & May 11 - December 24 0830 \\
\hline ORANGE & December 24 0830 - December 24 1440 \\
\hline RED & December 24 1440 - December 25 1930 \\
\hline ORANGE & December 25 1930 - December 31 \\
\hline \multicolumn{2}{|c|}{ KARYMSKY } \\
\hline ORANGE & January 1 - September 8 \\
\hline YELLOW & September 8 - September 15 \\
\hline ORANGE & September 15 - December 31 \\
\hline \multicolumn{2}{|c|}{ EBEKO } \\
\hline YELLOW & January 1 - February 24 \\
\hline GREEN & February 24 - December 31 \\
\hline
\end{tabular}


\begin{tabular}{|l|}
\hline Sheveluch Volcano \\
CAVW\# 1000-27 \\
$56^{\circ} 39^{\prime} \mathrm{N} 161^{\circ} 21^{\prime} \mathrm{E}$ \\
$3,283 \mathrm{~m}(10,768 \mathrm{ft})$ \\
Kamchatka Peninsula \\
LAVA DOME GROWTH CONTINUES \\
After months of relative quiescence, explosions and avalanches from the active dome resume in December. \\
\hline
\end{tabular}

The ongoing dome-growth eruption of Sheveluch Volcano entered 2006 quietly, with no reported or observed avalanches or ash plumes during the first 11 months of the year. Seismicity remained at or below background levels and KVERT maintained Level of Concern Color Code YELLOW. A weak fumarolic plume was frequently sighted over the new lava dome, and on occasion, satellite imagery revealed a small thermal anomaly. Brief periods of weak tremor and shallow volcano-tectonic earthquakes also occurred. Despite a flurry of activity in December 2006, dome growth did not produce major morphologic changes in the Sheveluch dome as determined by photographic comparison through the year (Y. Demyanchuk, IVS, written commun., 2007).

Relative quiescence ended abruptly on December 5 with a 14-minute period of strong explosions and avalanches from the dome that extended 3-5 km (2-3 mi) down slope.
No precursory seismicity had been detected. Ash rose to 4-6 $\mathrm{km}(13,000-20,000 \mathrm{ft})$ and the resulting cloud extended as far as $150 \mathrm{~km}$ (90 mi) downwind. Following the explosions, a vigorous fumarolic plume containing minor ash persisted above the dome. KVERT declared Level of Concern Color Code ORANGE at the onset of this event.

Additional brief but violent ash-emission events occurred into late December. Some were produced by impulsive explosions from the lava dome and others were precipitated by gravitational collapses of the dome. Visual and satellite analysis of these events indicated ash plumes reaching possibly as high as $10 \mathrm{~km}$ (33,000 ft) ASL on December 17 (fig. 57); the cloud from this event eventually extended more than $500 \mathrm{~km}$ (310 mi) east and northeast of the volcano. AVO staff tracked ash clouds on satellite imagery and conducted call-down notification of agencies each time an event produced

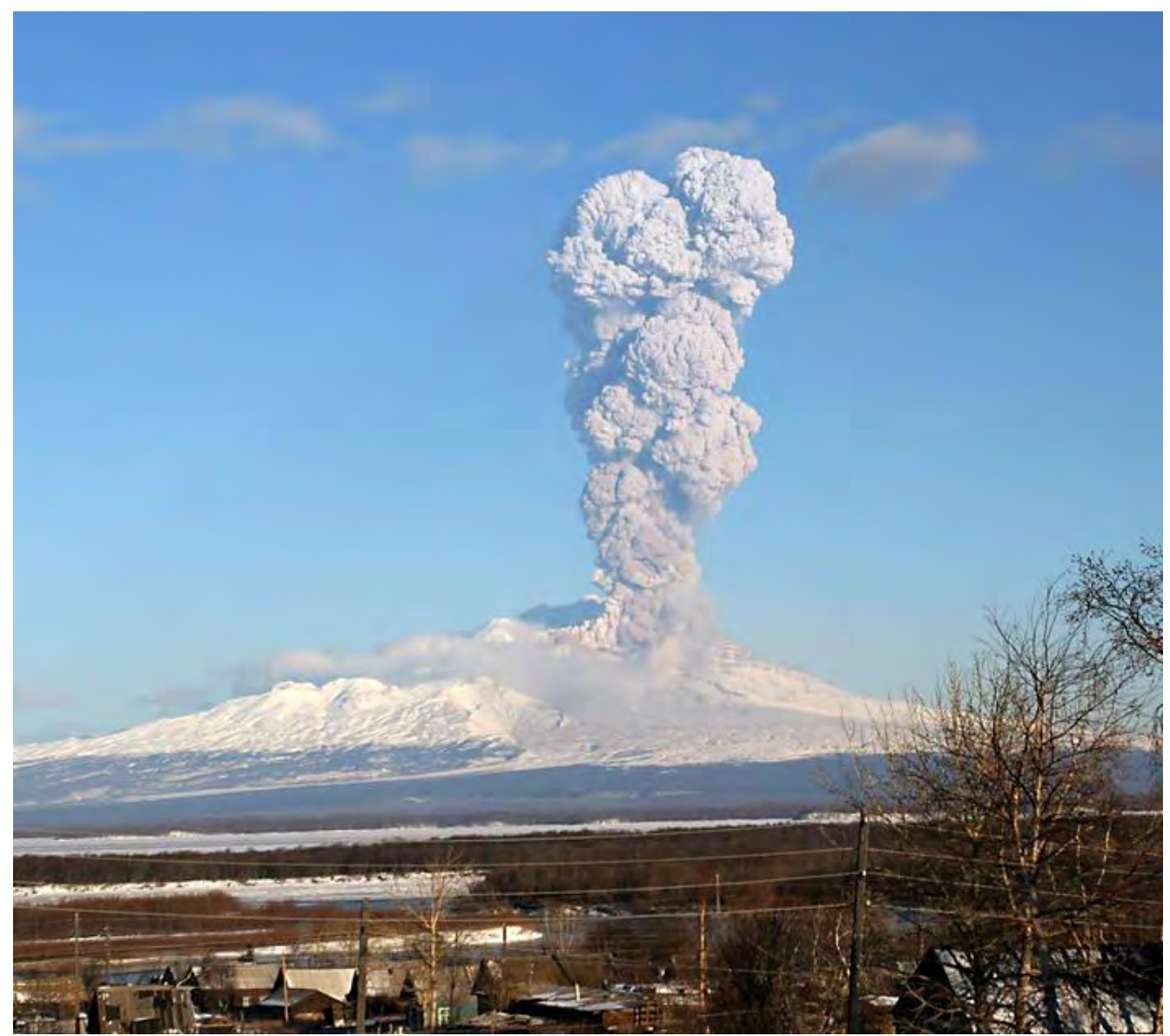

Figure 57. Sheveluch Volcano in eruption viewed to the north from Klyuchi, December 17, 2006. Photograph by Yuri Demyanchuk, IVS. 
ash that approached or exceeded 20,000 ft ASL and was announced by KVERT or KBGS via email. Multiple SIGMETs were issued by the Petropavlovsk Meteorological Watch Office at Yelizovo Airport and by the Alaska Aviation Weather Unit (AAWU). The Tokyo Volcanic Ash Advisory Center (VAAC) also issued numerous VAAs. For all these events of significance, AVO conducted a formal call-down of key agencies and faxed KVERT information releases to a predefined user list.

On December 25 (in the United States), Sheveluch produced another ash plume that reached $10 \mathrm{~km}(33,000 \mathrm{ft})$ ASL. The cloud drifted northeast and was tracked for more than $150 \mathrm{~m}$ (90 mi). KVERT raised the Level of Concern Color Code for Sheveluch to RED. Following this large explosion, Sheveluch entered a period of more continuous ash emission, with plumes reaching 4.5-6 km (5,000-20,000 ft) over the course of several days (fig. 58). KVERT declared Color Code ORANGE 2 days later. Periodic ash clouds related to avalanches and explosions from the lava dome continued through the end of the month.

The late 2006 activity prompted numerous notifications from Russian sources including KVERT, KBGS, the Tokyo VAAC. Additionally, the Yelizovo Airport Aviation Meteorological Center in Petropavlovsk released many dozens of SIGMETs to authorities in the United States, Japan, and to air carriers. AVO staff on duty received email notifications of significant ash plumes and conducted call downs as needed.

Sheveluch Volcano, the northernmost active volcano in Kamchatka, is one of the largest and most active volcanoes in Russia with at least 60 large eruptions during the Holocene (Bogoyavlenskaya and others, 1985; Ponomareva and others, 1998). Historical eruptive activity has been characterized by lava-dome growth and explosive collapse, often accompanied by large debris avalanches. Its most recent catastrophic collapse event in 1964 formed the modern amphitheater within which the active lava dome is now growing (Zharinov and others, 1995). The current, protracted phase of intermittent lava-dome growth began in late September 1980 and continues into 2007. The repetitive nature of this ongoing activity has enabled KGBS scientists to develop a reliable method of using seismic data to estimate plume heights (Sergey Senyukov, KBGS, written commun., 2006).

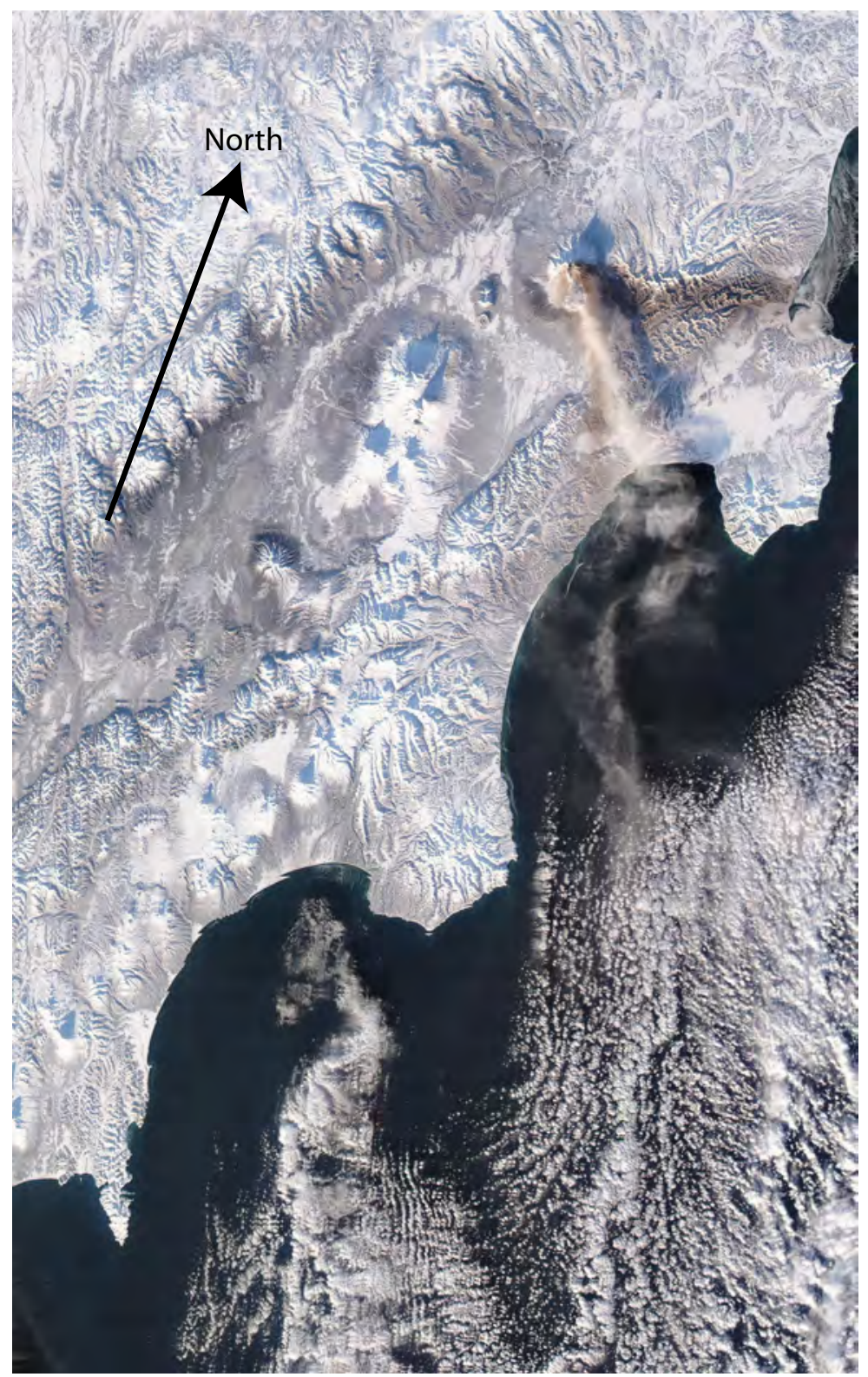

Figure 58. MODIS image of ash cloud from Sheveluch Volcano on December 27, 2006, at 0135 UTC. 


\begin{tabular}{l}
\hline Klyuchevskoy Volcano \\
CAVW\# $1000-26$ \\
$56^{\circ} 03^{\prime} \mathrm{N} 160^{\circ} 39^{\prime} \mathrm{E}$ \\
$4,750 \mathrm{~m}(15,589 \mathrm{ft})$ \\
Kamchatka Peninsula, Russia \\
INCREASED SEISMICITY; THERMAL ANOMALY RETURNS IN MID-DECEMBER \\
No eruption.
\end{tabular}

Following its last phase of vigorous Strombolian and Vulcanian activity in January-March 2005 (McGimsey and others, 2007), Klyuchevskoy Volcano remained at Level of Concern Color Code GREEN until a period of increasing seismicity that began in mid-December. Based on this, KVERT raised the volcano to Level of Concern Color Code YELLOW on December 19. This seismicity was accompanied by a small thermal anomaly at the summit crater that emitted an intermittently visible fumarolic plume. The volcano remained at Color Code YELLOW with slightly elevated seismicity through the end of the year.
Klyuchevskoy is a classic, symmetrical stratovolcano (fig. 59) and, at 4,750 m (15,589 ft) ASL, it is the highest of the active European and Asian volcanoes. Klyuchevskoy is frequently active with Strombolian to Vulcanian explosions and occasional lava-flow production from the main vent in the steep-walled summit crater or from flank vents (Khrenov and others, 1991). Explosive eruptions have been recorded in nearly every decade and at multiple times during most years since the early 1700s (Simkin and Siebert, 1994).

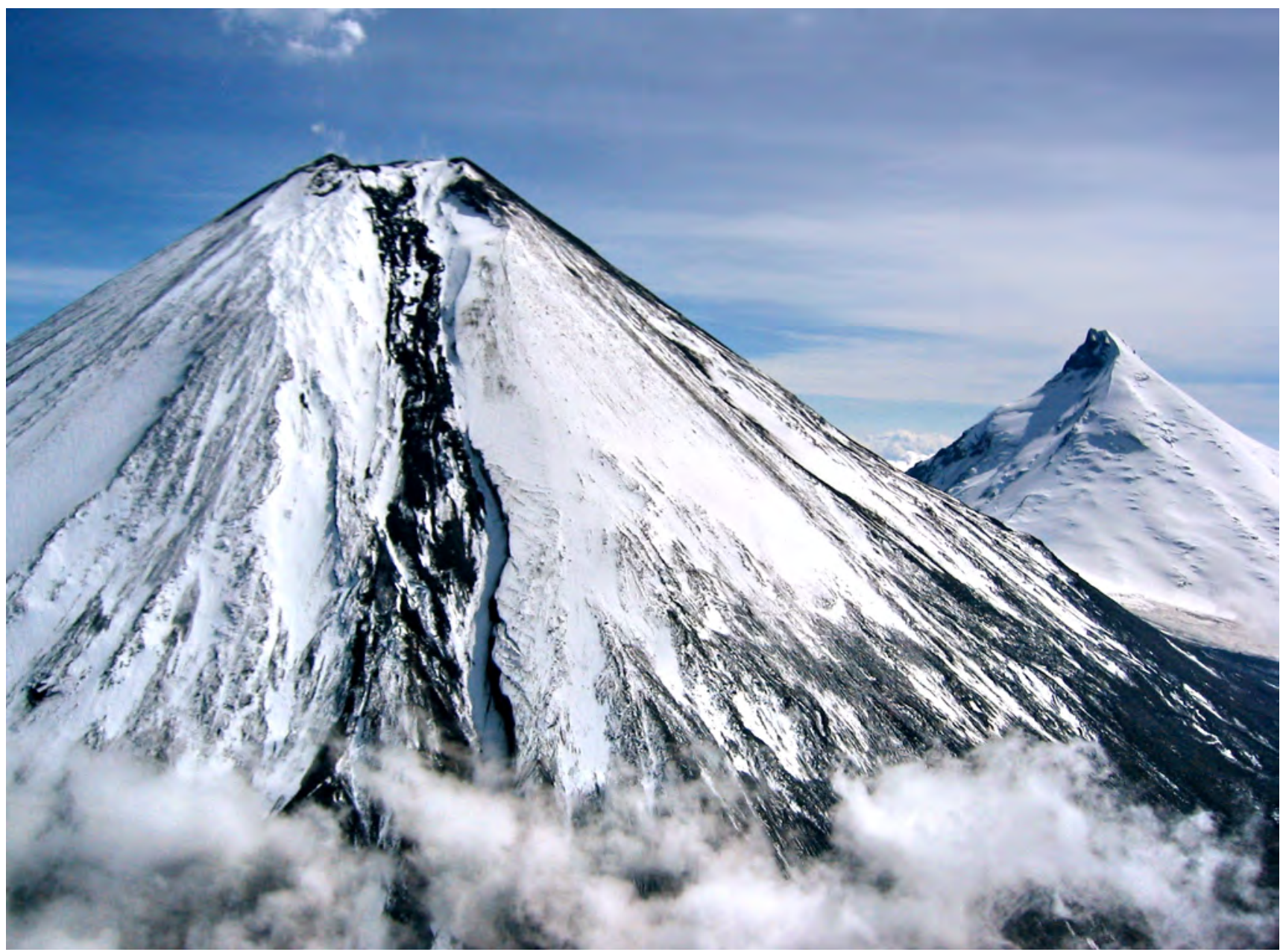

Figure 59. Aerial view of Klyuchevskoy Volcano during a helicopter overflight, August 11, 2006. The 2005 lava flow forms the dark stripe down the near flank. Inactive Kamen Volcano at right. Photograph by Wendy Stovall (used with permission), University of Hawaii. 


\section{Bezymianny Volcano}

CAVW\# 1000-25

$55^{\circ} 58^{\prime} \mathrm{N} 160^{\circ} 36^{\prime} \mathrm{E}$

$2,882 \mathrm{~m}(9,455 \mathrm{ft})$

Kamchatka Peninsula, Russia

INTERMITTENT LAVA DOME GROWTH, LARGE EXPLOSIVE EVENTS IN MAY AND DECEMBER

Bezymianny Volcano continued its decades-long, intermittent lava-dome growth activity in 2006. Beginning the year at Level of Concern Color Code YELLOW with seismicity rarely exceeding background levels, KVERT nonetheless inferred that active lava effusion continued. Fumarolic plumes were frequently sighted above the dome and satellite imagery detected a thermal anomaly of varying size coincident with the active dome in the summit crater.

On April 7, KVERT reported a new 'lava block' extruding from a north-south fissure across the summit of the lava dome (fig. 60) and suggested the volcano was moving towards an explosive eruption. On May 5, KVERT reported an increased likelihood of explosive eruption within the next 4 weeks. Seismicity was above background for much of this period and began to increase in mid-May.
On May 7, KVERT raised the Level of Concern Color Code to ORANGE, noting an increasing number of hot avalanches from the unstable dome. Fumarolic plumes containing ash rose above the summit and numerous shallow earthquakes were recorded under the volcano. Two days later, after the appearance of intermittent spasmodic tremor, a strong thermal anomaly, and a continuing high level of avalanche activity, KVERT declared Level of Concern Color Code RED and indicated that an explosive eruption was possible in the next several days.

The forecast was correct. On May 9 at 08:21 UTC, a 24-minute-long explosive eruption accompanied by significant pyroclastic avalanches sent ash to $15 \mathrm{~km}(49,000 \mathrm{ft}) \mathrm{ASL}$ (fig. 61). The ash cloud extended south-southeast and then later northeast from the volcano. Satellite images tracked this

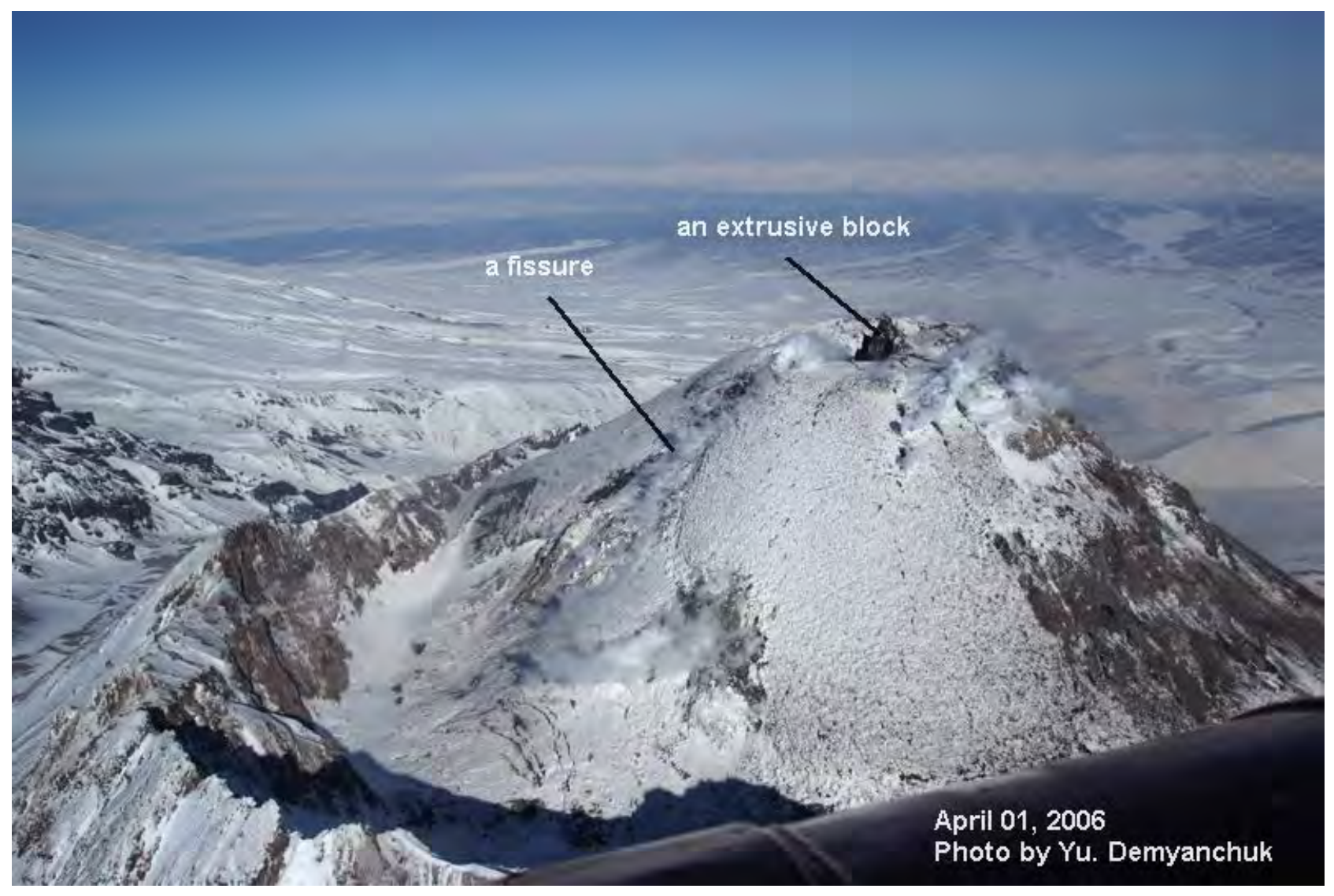

Figure 60. Aerial view of the summit crater and active dome of Bezymianny Volcano, April 1, 2006. Actively extruding block of lava was noted by KVERT in an Information Release in early May when they announced the increasing likelihood of an explosive eruption. Photograph by Yuri Demyanchuk, IVS. 


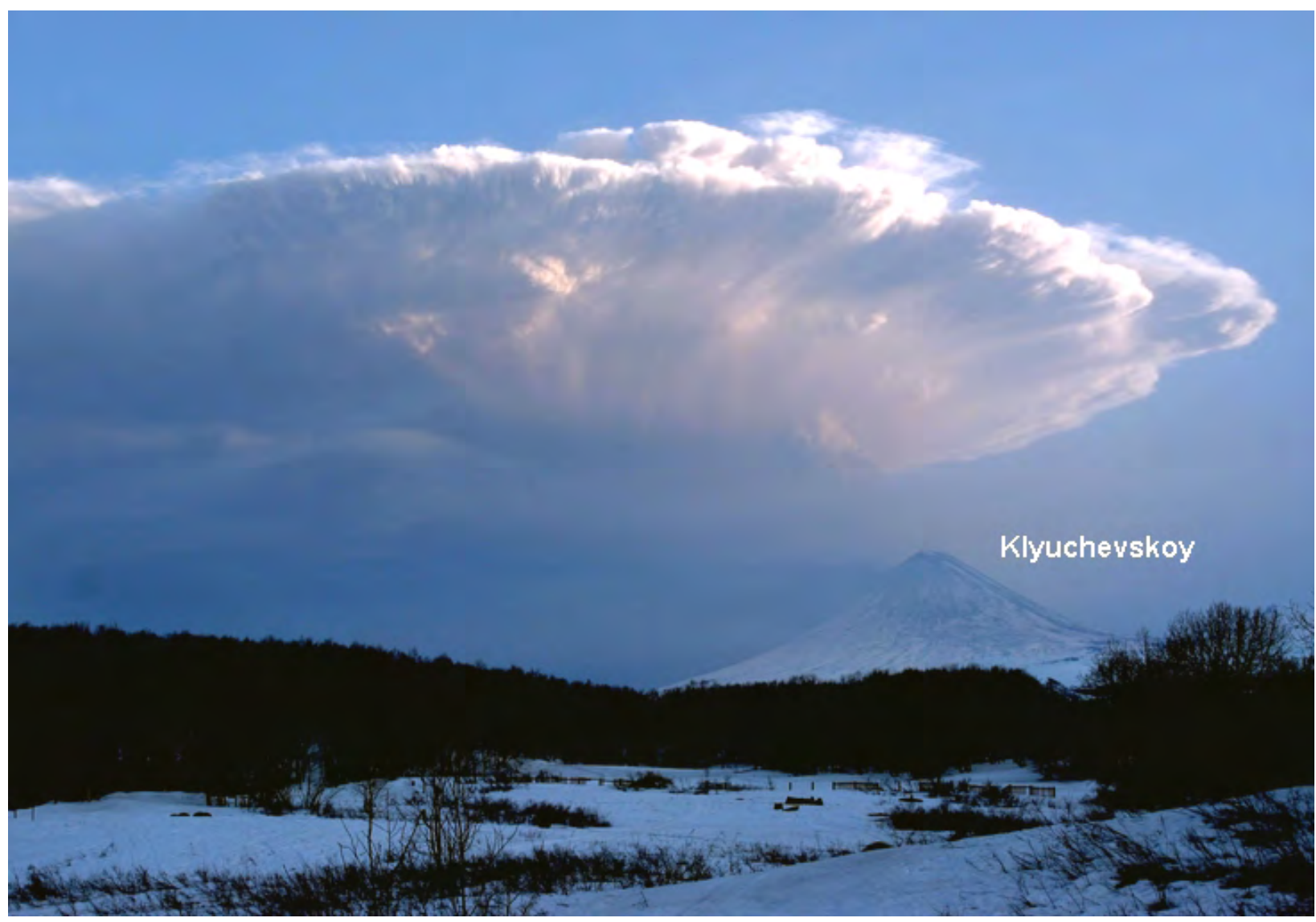

Figure 61. Bezymianny eruption cloud, May 9, 2006. Photograph by Yury Demyanchuk, IVS. The Bezymianny edifice is obscured. Klyuchevskoy Volcano is labeled in the foreground. View is from the north in the town of Klyuchi.

cloud for more than $500 \mathrm{~km}$ (310 mi). In response, the AAWU issued several SIGMETs and Tokyo VAAC issued several VAAs. Several air carriers rerouted their planes to avoid the ash cloud. A pilot report of ash between an estimated 40,00045,000 ft (12.2-13.7 km) ASL about $250 \mathrm{mi}(400 \mathrm{~km})$ west of Shemya in the far western Aleutian Islands was followed within a few hours by an ash-fall advisory for the western Aleutians; no ash fall was subsequently reported.

The Level of Concern Color Code reverted to ORANGE on May 10 and YELLOW on May 11 as seismicity returned to background levels and quiet effusion of lava resumed. A strong thermal anomaly and fumarolic plume persisted above the lava dome. A helicopter overflight on July 31 noted a new extrusive lobe of lava in the southwestern portion of the active dome.

During the summer of 2006, KBGS installed two new permanent seismic stations to augment the existing Bezymianny network (figs. 62 and $\underline{63}$ ).
The size of the summit thermal anomaly and background seismicity began to increase again in mid-December and on December 22, KBGS scientist Sergey Senyukov shared a formal prediction of an eruption within the next month at the 90 percent confidence level. The next day, this forecast was modified to indicate a likely eruption window of December 23-31. Within 24 hours, seismicity accelerated significantly and video monitoring detected an increasing number of avalanches off the dome. KVERT issued Level of Concern Color Code ORANGE on the morning of December 24 in Kamchatka and then RED 6 hours later. Ash clouds from ensuing avalanches ascended to 20,000 ft ASL.

Less than 9 hours after raising the alert level to RED, a significant explosive event began at Bezymianny, sending ash to an estimated $10 \mathrm{~km}(33,000 \mathrm{ft})$. The cloud drifted generally northeast from the volcano and did not significantly impact traffic on North Pacific Air Corridor (NOPAC), Russian TransEast, or Cross-Polar flight routes. 


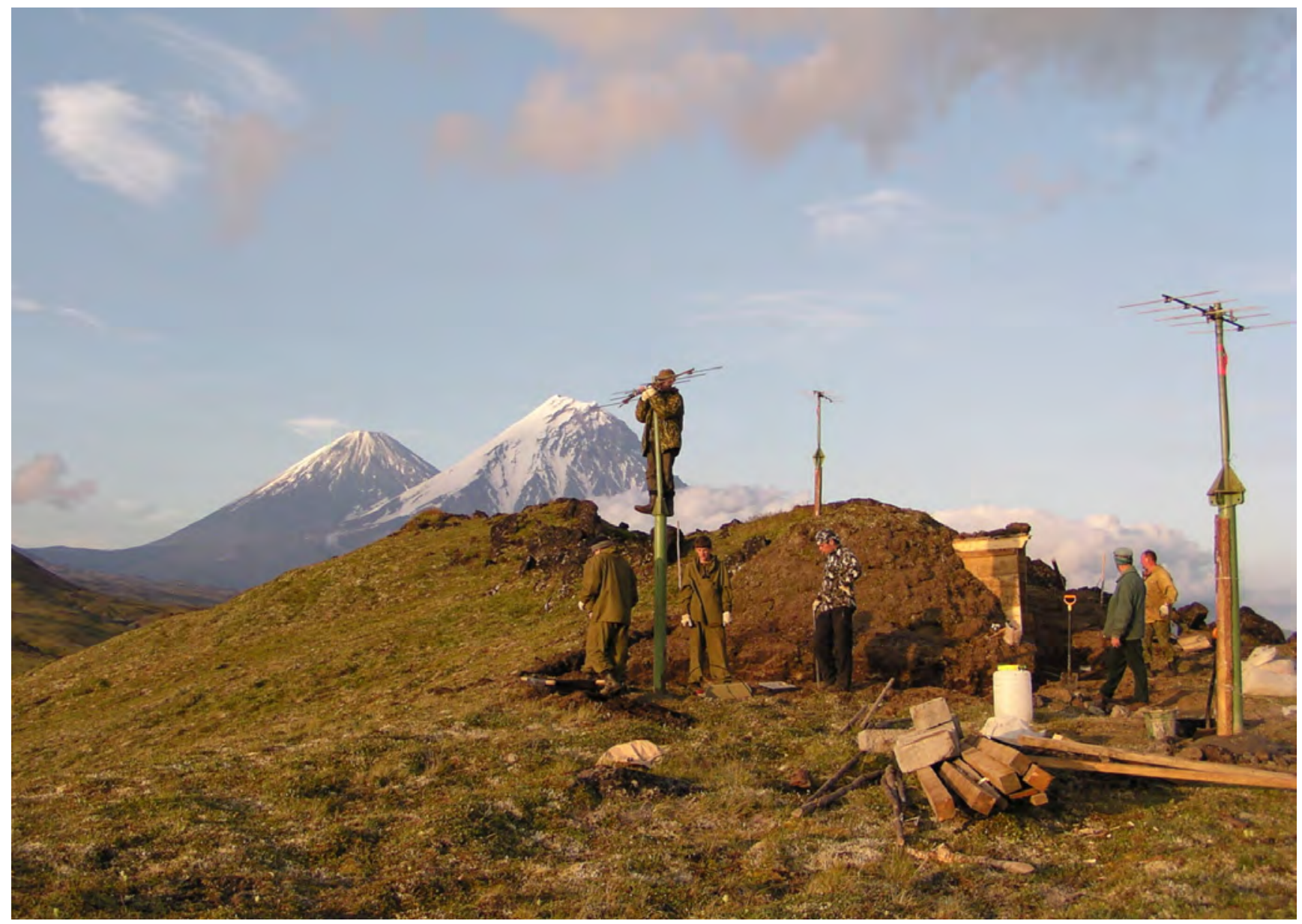

Figure 62. New seismic station being installed as part of a network for monitoring Bezymianny Volcano. This new station is called KIR and is about $6.5 \mathrm{~km}$ (4 mi) west of the volcano. Klychevskoy and Kamen Volcanoes are in the distance to the northeast of this new station; Bezymianny is out of the photograph to the right. Photograph by Sergey Senyukov, KBGS.

KVERT downgraded to Level of Concern Color Code ORANGE the next afternoon after seismicity and ash emission decreased and remained there through the end of the year. A significant thermal anomaly in the vicinity of the dome and extending southeast from the dome area indicated emplacement of new, hot material, likely pyroclastic-avalanche deposits from the active dome area. KVERT reported that viscous lava was likely erupting at the active dome. A helicopter overflight in late December confirmed that a portion of the dome had been destroyed in the December explosion; new pyroclastic-flow deposits extended down the flank of the volcano (fig. 64).
In October 1955, Bezymianny emerged from a 900-1,000 year period of quiescence into an eruption that culminated on March 30, 1956, with the catastrophic failure and accompanying debris avalanche and lateral blast similar to what occurred at Mount St. Helens in 1980 (Voight and others, 1981). Since then, lava extrusion has produced a dome that periodically collapses, generating pyroclastic flows and shortlived ash plumes (Girina and others, 1993; McGimsey and others, 2005a). 


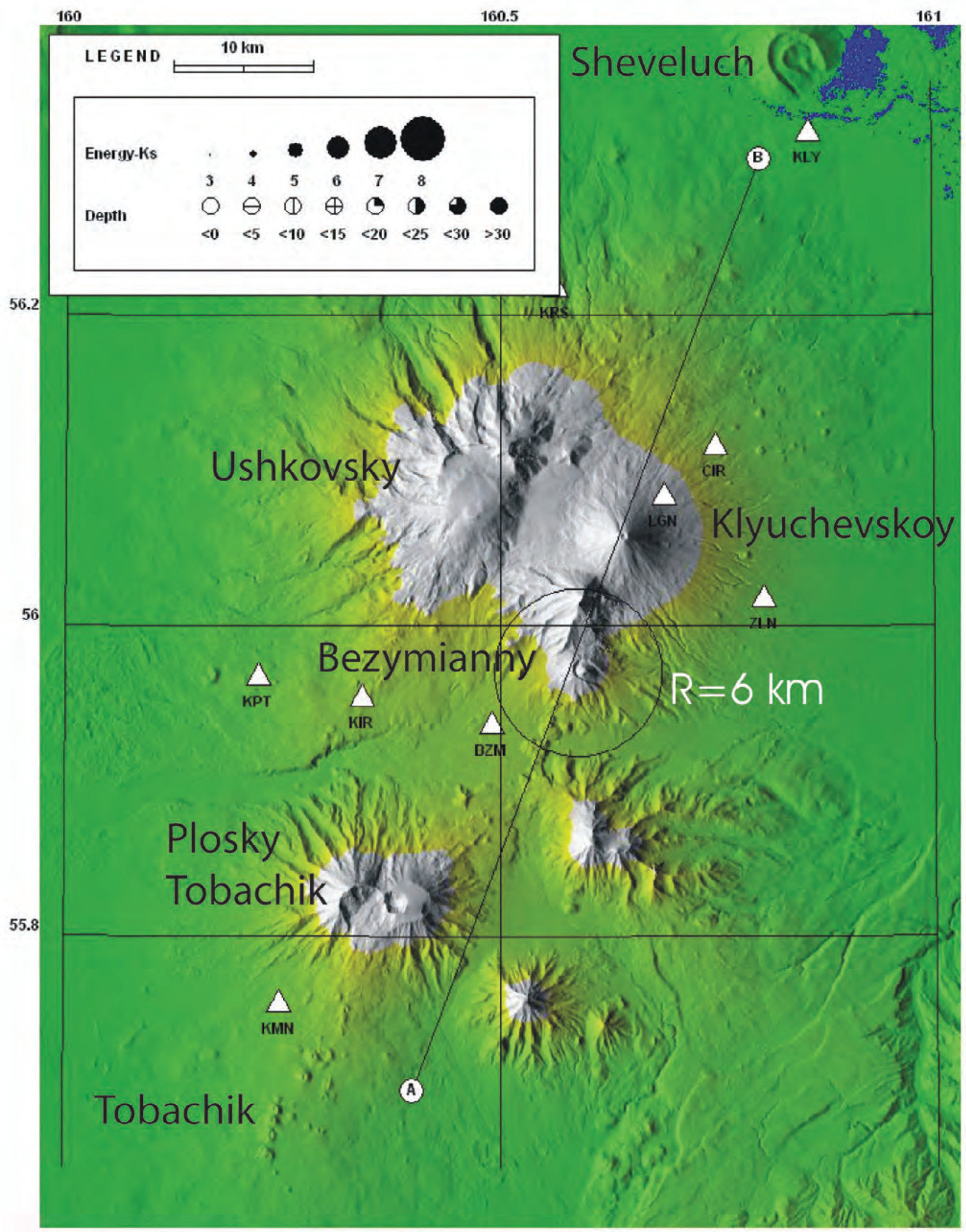

Figure 63. Seismic stations (white triangles) in the vicinity of the Klyuchevskoy group of volcanoes and Sheveluch (northernmost volcano), 2006. Map courtesy of Sergey Senyukov, KBGS. 


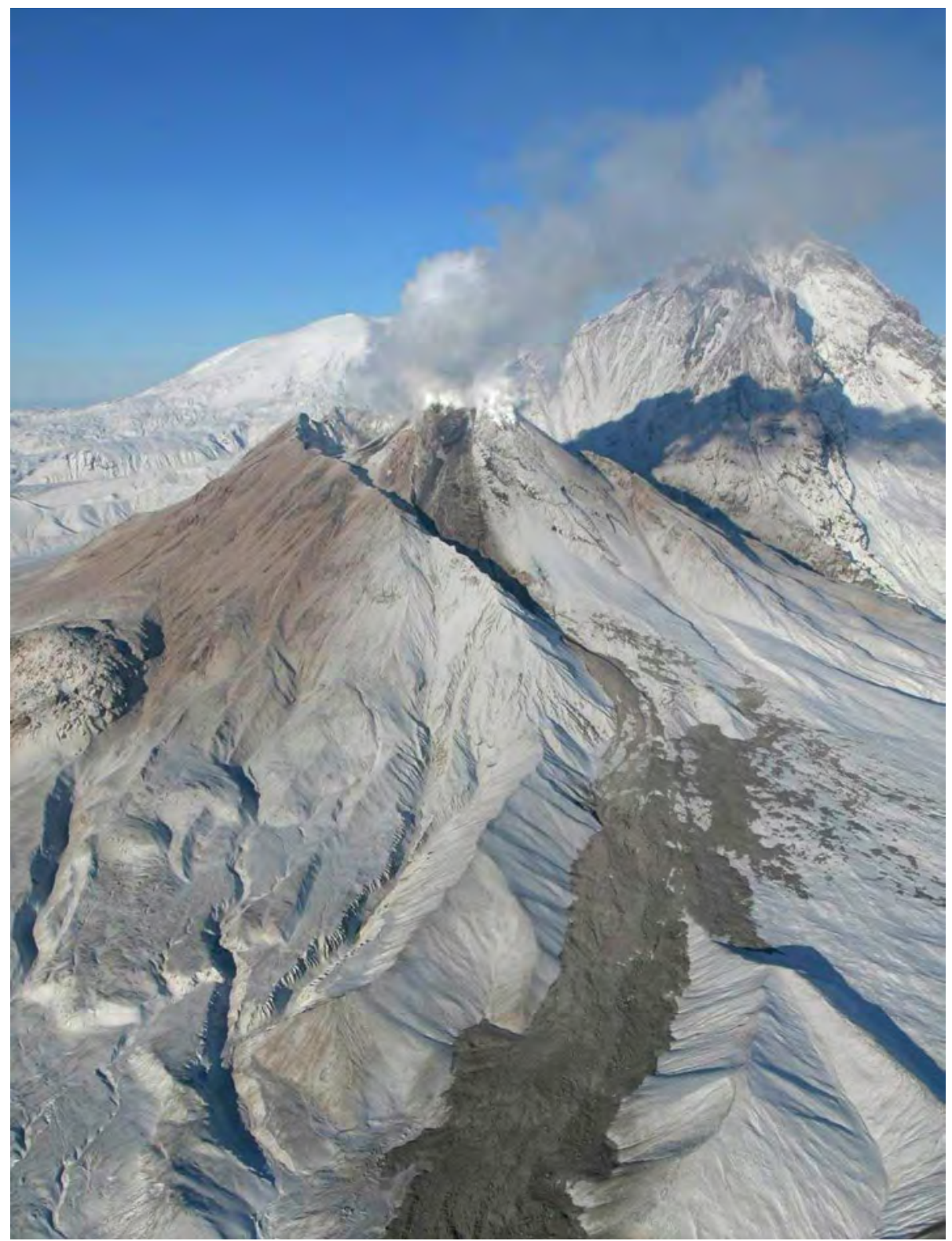

Figure 64. Bezymianny Volcano from the south, December 27, 2006. Lobate pyroclasticflow deposits extend downslope from the south side of the active lava dome. Photograph by Yuri Demyanchuk, IVS. 


\title{
Karymsky Volcano
}

\author{
CAVW\# 1000-13
}

$54^{\circ} 03^{\prime} \mathrm{N} 159^{\circ} 27^{\prime} \mathrm{E}$

$1,486 \mathrm{~m}(4,876 \mathrm{ft})$

Kamchatka Peninsula, Russia

STROMBOLIAN / VULCANIAN ERUPTION CONTINUES INTERMITTENTLY

Ash clouds, local ash fall.

Karymsky Volcano completed its $11^{\text {th }}$ year of eruption, remaining at Level of Concern Color Code ORANGE for nearly all of 2006. Vulcanian explosions from the summit crater, occurring at rates of four to five bursts per hour on occasion, produced short-lived, small-volume ash plumes, usually well below $6 \mathrm{~km}(20,000 \mathrm{ft})$ and extending a few tens to more than $200 \mathrm{~km}(124 \mathrm{mi})$ from the volcano (figs. 65 and 66). Significant thermal anomalies were detected frequently on satellite images. Many explosions were reported by pilot reports during the year; however, most explosions were detected only on the basis of seismicity. Periods of tremor and many hundreds to more than 1,000 earthquakes per day were detected during phases of multiple, closely spaced explosions (fig. 67). A handful of explosions sent ash above $20,000 \mathrm{ft}$ $(6 \mathrm{~km})$ ASL. Several gaps in seismic data occurred over the course of the year; during these times, eruptions were detected only via pilot reports or the occasional serendipitous satellite image.
Karymsky is the most active volcano on the Kamchatkan Peninsula (Simkin and Siebert, 1994). Explosive and effusiveexplosive eruptions of andesitic tephra and lava flows alternating with periods of repose are typical of Karymsky (Ivanov and others, 1991). The current phase of unrest began in mid-April 1995 with increasing seismicity and culminated in an explosive eruption that began on January 1, 1996. Initial eruptive activity occurred simultaneously at Karymsky Volcano and from a vent at the north part of Karymsky Lake a distance of about $10 \mathrm{~km} \mathrm{(6} \mathrm{mi;} \mathrm{(Fedotov,} \mathrm{1998;} \mathrm{Belousov}$ and Belousova, 2001). For the next several years, periods of explosive eruptions of ash and small blocks alternated with periods of lava-flow production.

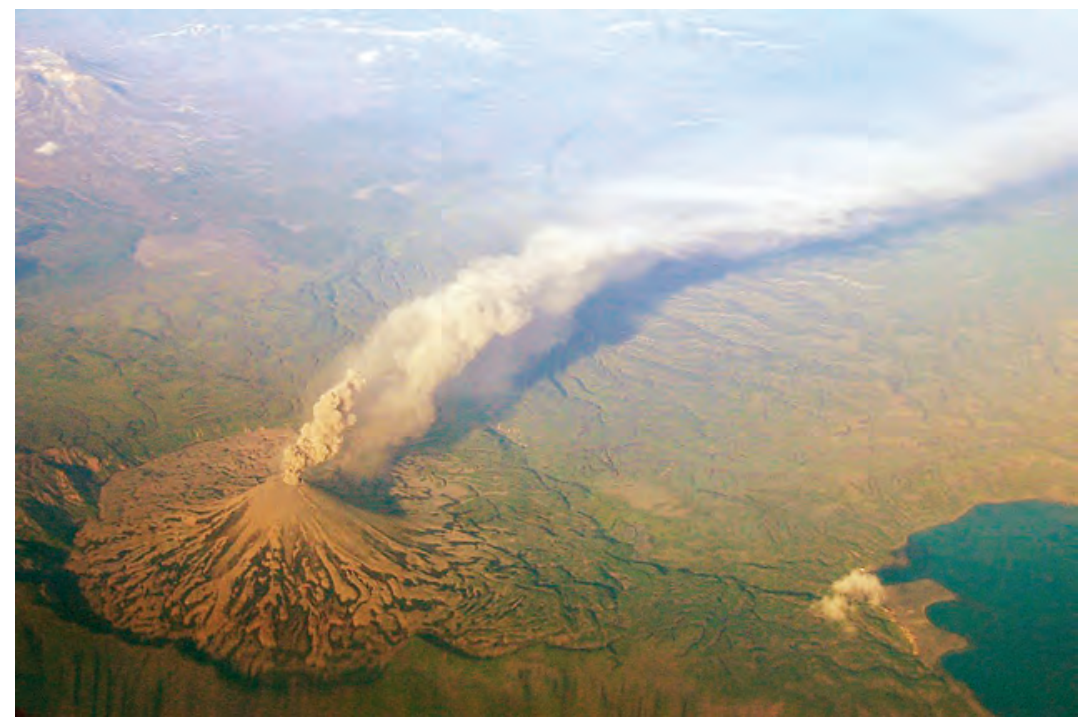

Figure 65. Karymsky Volcano in eruption as seen through the haze from the cockpit of a jet flying at 9,100 m altitude $(29,800 \mathrm{ft})$ ASL, June 28, 2006. Photograph by pilot Hiroshi Ando (used with permission) on Russia TransEast Route G583 between waypoints GEFAR (N54 12.8, E159.48.1) and IRKAN (N55.20.0, E162.56.4). 


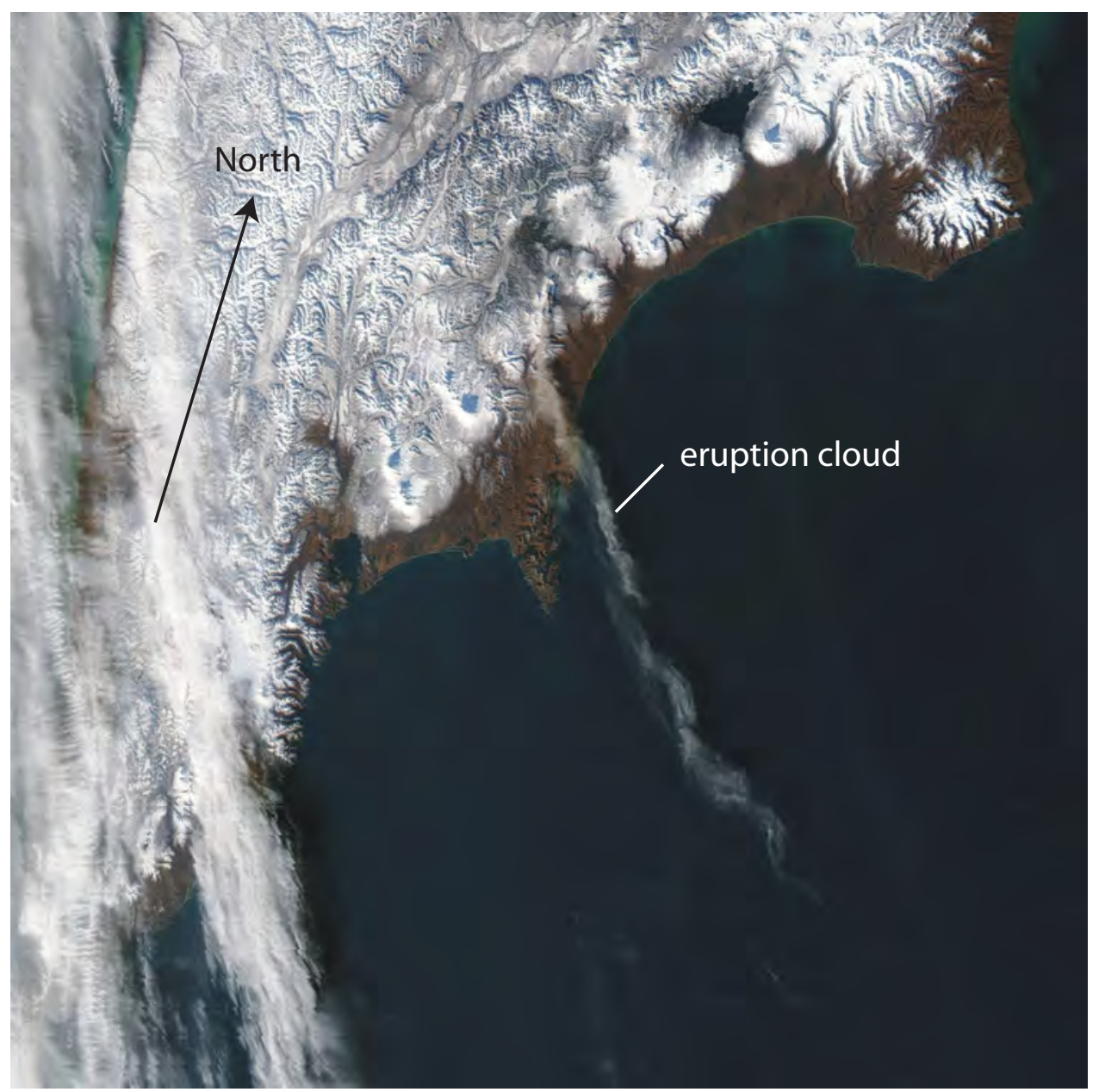

Figure 66. MODIS image of

Karymsky Volcano eruption cloud, November 7, 2006. MODIS image courtesy of Sergey Senyukov, KBGS.

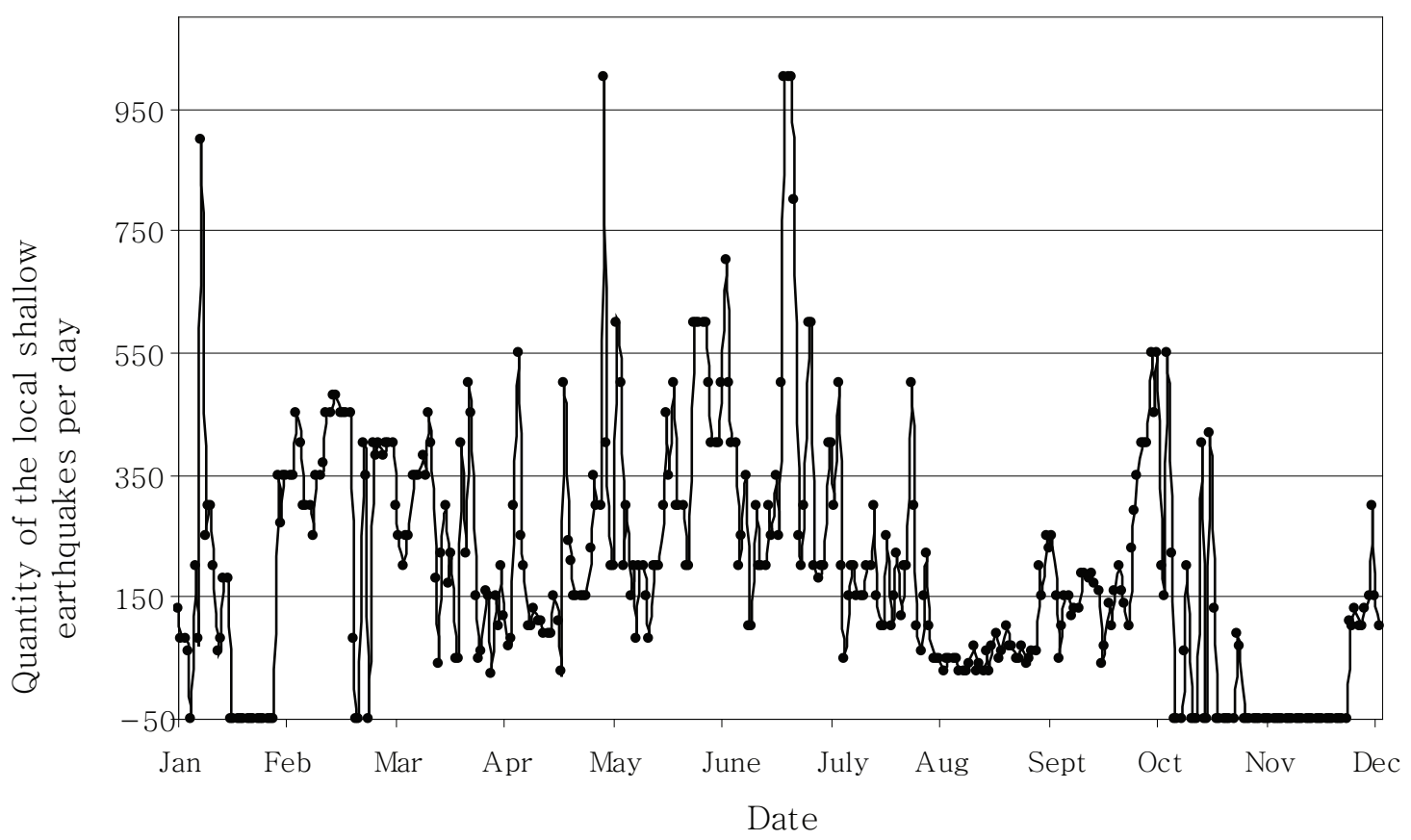

Figure 67. Number of shallow earthquakes per day at Karymsky Volcano, 2006. Most of the shallow earthquakes correspond to gas-ash plumes. Values of $(-50)$ indicate no data due to station outages. Plot prepared by A. Manvich, IVS. 


\section{Volcanic Activity, Kurile Islands}

The Institute of Marine Geology and Geophysics (IMGG), the host institute for the Sakhalin Volcanic Eruption Response Team (SVERT; Rybin and others, 2004), reports on activity at Kurile Island volcanoes (fig. 68). SVERT uses twice-daily MODIS imagery of the Kurile Islands, timedelayed seismic data from Kunashir and Iturup Islands, and visual observations from several southern Kurile Islands. By agreement between SVERT and KVERT, the northernmost Kurile Islands of Paramushir and Alaid are under the reporting jurisdiction of KVERT.

In 2006, a period of heightened fumarolic activity occurred at Ebeko Volcano. Plumes of possible volcanic origin were noted at two other Kurile volcanoes, Berga and Severgin.

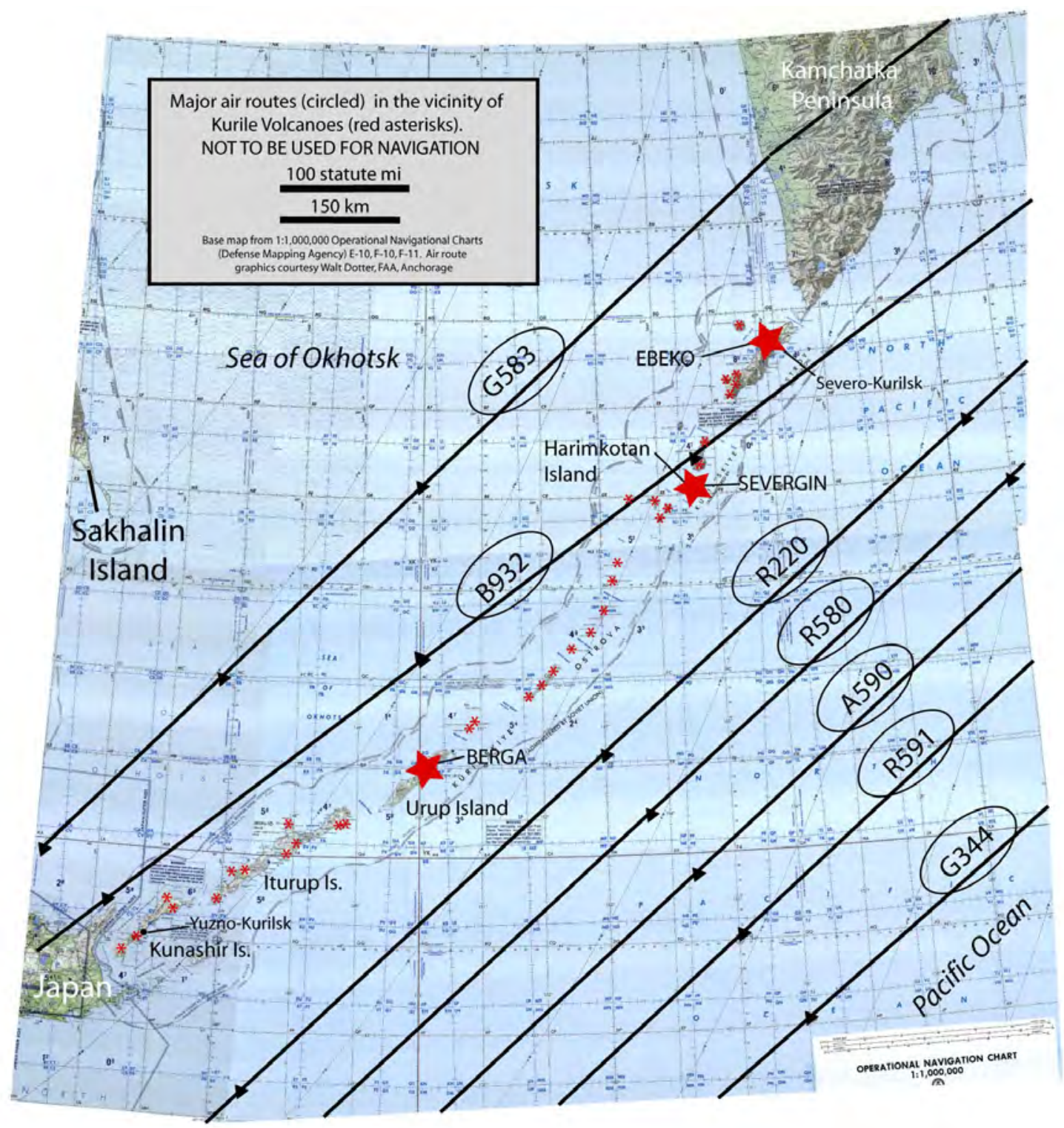

Figure 68. Kurile Islands with place names used in this report. Mosaic of Operational Navigation Charts F10, F11, and E10 (Defense Mapping Agency) for the NOPAC showing major air routes (bold black lines, numerical designator of each airway is circled) and locations of active volcanoes of the Kuriles (red asterisks). Selected airway navigational fixes are shown as black triangles. Volcanoes mentioned in this report are labeled. 


\section{Ebeko Volcano}

CAVW\# 0900-38

$50^{\circ} 41^{\prime} \mathrm{N} 156^{\circ} 01^{\prime} \mathrm{E}$

$1,156 \mathrm{~m}(3,793 \mathrm{ft})$

Paramushir Island, North Kuriles, Russia

STRONG FUMAROLIC ACTIVITY

Ebeko Volcano began 2006 at Level of Concern Color Code YELLOW. Strong fumarolic activity from the summit area was accompanied by strong odors of hydrogen sulfide and chorine gas in Severo-Kurilsk. A robust volcanic gas plume from Ebeko is not uncommon in this community when wind conditions are unfavorable. No explosive activity was noted and magmatic gas odors gradually decreased into February. On February 24, KVERT downgraded Ebeko to Color Code GREEN.

Ebeko is a 1,156 m (3,793 ft) high composite stratovolcano with a central cone and three summit craters on the northern end of Paramushir Island in the North Kuriles (Gorshkov, 1970). The northernmost of the Ebeko craters has at times contained a small, cold lake (Gorshkov, 1970) and the middle crater contains a lake as well as numerous solfataras that occur along the lakeshore and the floor of the lake. The central Ebeko cone is at the northern end of a complex of five volcanic cones. Lava flows and pyroclastic material range in composition from basaltic to andesitic (Gorshkov, 1970). Historic eruptive characteristics include central-vent eruptions, explosive eruptions, phreatic explosions (often involving the crater lakes), lahars, fumarolic activity, and radial-fissure eruptions. The north crater has been the focus of activity since at least the 1987-89 eruption (Siebert and Simkin, 2002-). The most recent eruption, in 2005 (VEI 2), was characterized by gas, steam, and some ash emissions (Siebert and Simkin, 2002-; Smithsonian Institution, 2005; McGimsey and others, 2007). No seismometers are installed on or near Ebeko; KVERT uses satellite imagery and occasional ground-based observations to monitor activity at the volcano. 


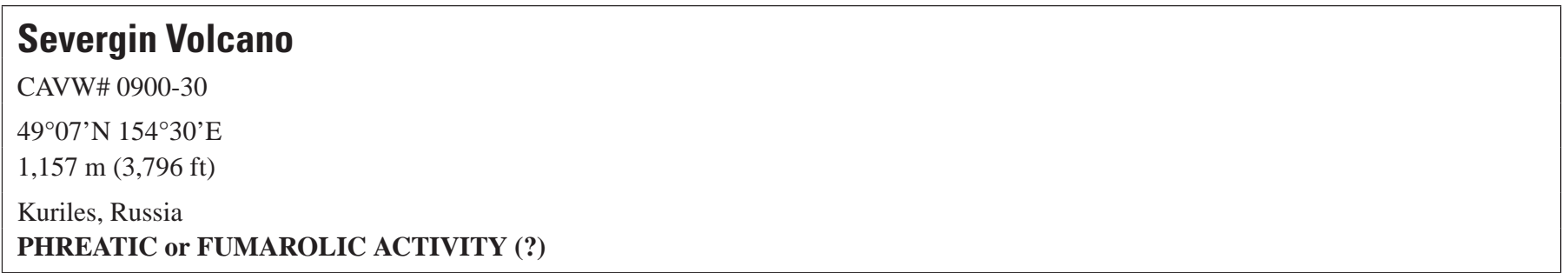

In a routine daily report from SVERT on August 27, scientists at the IMGG noted a possible ash plume from Severgin Volcano in the North Kuriles during examination of MODIS imagery (fig. 69). The cloud was not large and no ground-based confirmation was received for activity on this remote, uninhabited, and seismically unmonitored volcano.

Severgin is a composite, mostly dacitic stratovolcano that makes up Harimkotan Island (fig. 68). The volcano has a complex structure resulting from repeated flank failures and large eruptions (Gorshkov, 1970). Severgin is notable for the largest historical explosive eruption in the Kurile Islands, a VEI 5 eruption in 1933 (Siebert and Simkin, 2002-). This eruption produced a debris avalanche that created a tsunami up to $20 \mathrm{~m}$ (66 ft) high that hit the coast of Onekotan and Paramushir Island; two people were killed (Siebert and Simkin, 2002-). A lava dome formed in the crater left by the destroyed cone at the end of the 1933 eruption (Gorshkov, 1970). Other historic eruptions are reported in the years 1713 , 1846, 1848(?), 1883, and 1931.
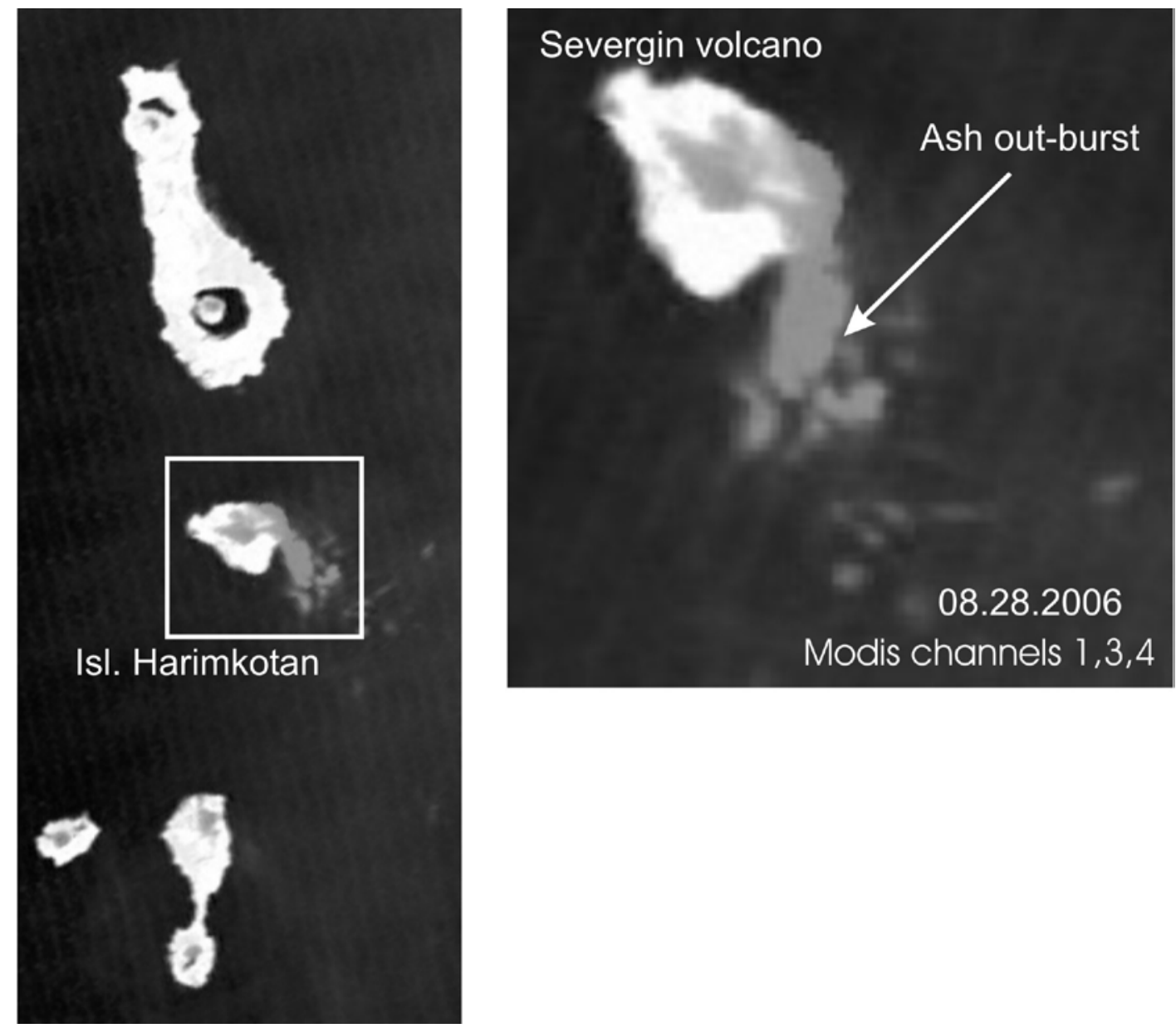

Figure 69. Satellite image composites of possible activity from Severgin Volcano. Harimkotan Island is about 8 by $12 \mathrm{~km}$ across ( 5 by $7 \mathrm{mi}$ ). 


\author{
Berga Volcano (Kolokol Group) \\ CAVW\# 0900-12 \\ $46^{\circ} 03^{\prime} \mathrm{N} 150^{\circ} 04^{\prime} \mathrm{E}$ \\ $980 \mathrm{~m}(3,215 \mathrm{ft})$ \\ Kuriles, Russia \\ PHREATIC Or FUMAROLIC ACTIVITY
}

SVERT staff noted a possible steam and gas plume from Berga Volcano on Urup Island on November 7. AVO remote sensing specialists examined visual MODIS imagery of the scene reported by SVERT and did not identify any cloud of volcanic origin. No further reports of activity were forthcoming and neither AVO nor SVERT conducted any formal call downs.
Centrally located on the western side of Urup Island in the South Kuriles (fig. 68), Berga Volcano is a composite stratovolcano considered part of the Kolokol Group of volcanoes. Known eruptions of Berga occurred in 1946, 1951-52, 1970, and 2005 and ranged in size from VEI 2 to VEI 3. Vigorous fumarolic activity at Berga is, at times, quite impressive (figs. 70 and $\underline{71}$ ).

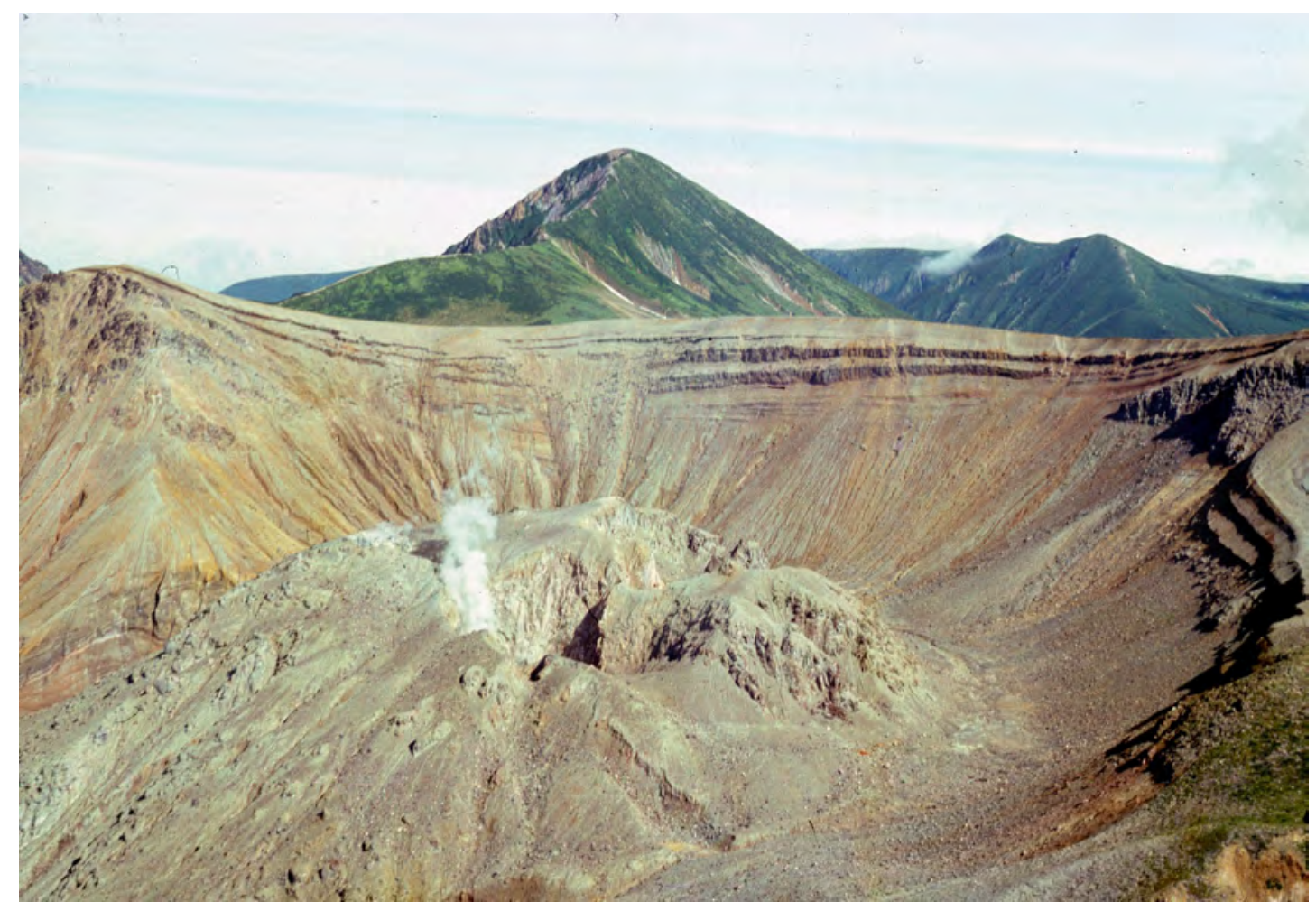

Figure 70. Berga Volcano showing central lava dome with active fumarolic emission within the 2-km (1.2-mi) diameter Berg caldera, 1996. View from the north. Inactive Kolokol Volcano is against the background. Photograph by Alexander Rybin, IMGG. 


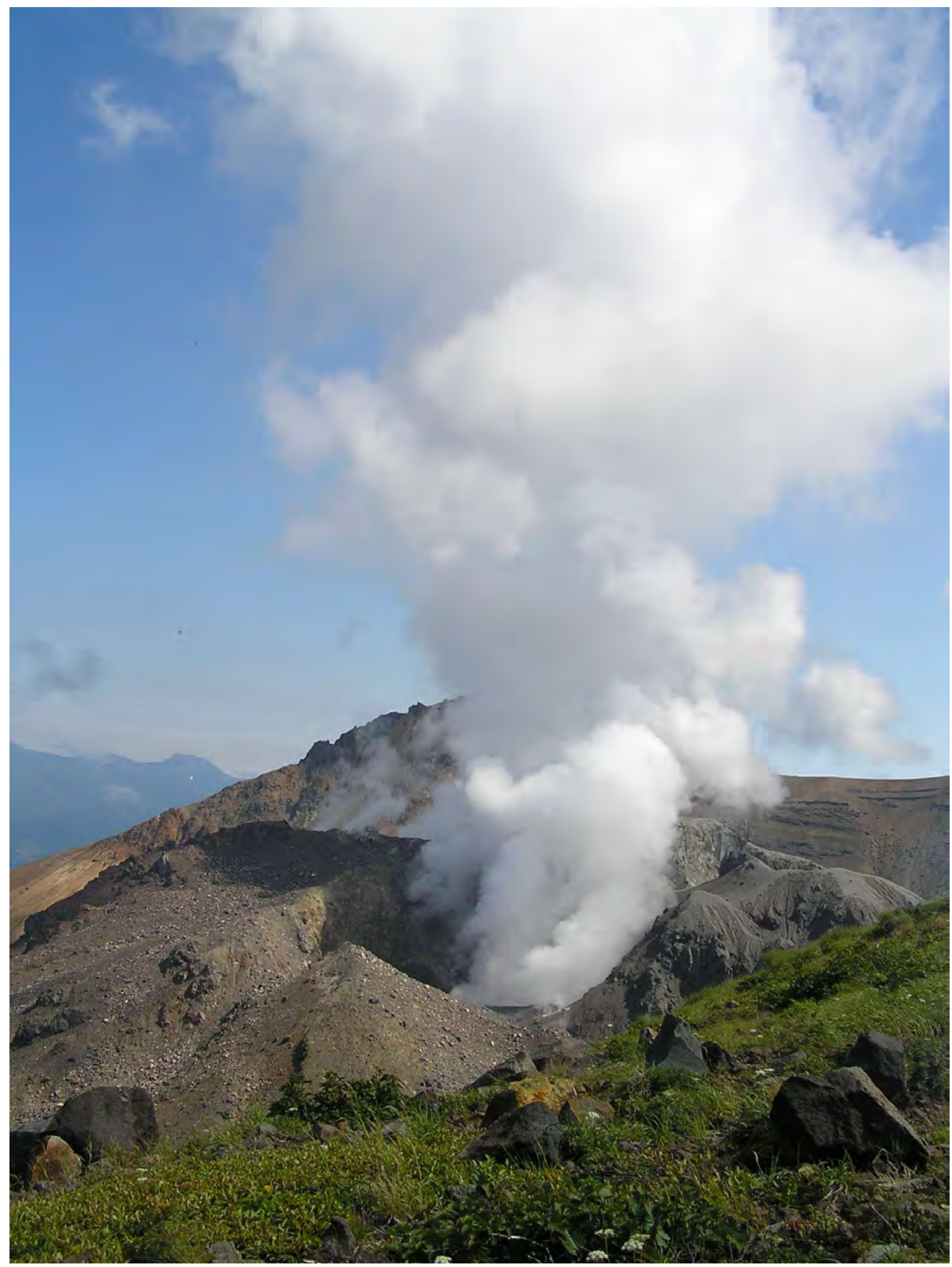

Figure 71. Strong water vapor and volcanic-gas emission at Berga Volcano, 2005. Photograph by V. Galversten, IMGG. 


\section{Summary}

The Alaska Volcano Observatory and colleagues at collaborating institutions in Russia had a very busy 2006. Staff responded to volcanic unrest at or near nine separate volcanic centers in Alaska including the first eruption in 14 years within several hundred kilometers of principal population centers at Augustine Volcano in lower Cook Inlet. A surprise eruption at glaciated Fourpeaked volcano, thought to have been inactive in the Holocene, was a reminder that many volcanic centers in Alaska are still only understood at a reconnaissance level. Multiple eruptions from ongoing eruptions at several Kamchatkan volcanoes sent ash repeatedly across the heavily traveled North Pacific and Russian TransEast air routes, however, no aircraft encounters with ash occurred.

\section{Acknowledgments}

This report represents the work of the entire Alaska Volcano Observatory, colleagues from other USGS Volcano Observatories, staff at cooperating agencies, and the public. Russian activity documented here reflects tenacious monitoring, documentation, and analysis by scientists at the Institute of Volcanology and Seismology, the Kamchatkan Branch of Geophysical Surveys, and the Institute of Marine Geology and Geophysics. In particular, we thank Sergey Senyukov of KBGS for his generous sharing of information and insights. We also acknowledge the significant contributions of our colleagues at ADGGS for design and maintenance of the Alaska Volcano Observatory logs and image database, powerful tools for review of activity through the year. Technical reviews by Kate Bull and Bill Burton significantly improved the content and presentation. All images and photographs from our colleagues and the public in this report are appreciated and used with permission. The authors wish to acknowledge partial funding support for this work from the Federal Aviation Administration.

\section{Sources of Photographs in This Report and Other Images of Alaska and Russia}

Online sources of digital images from this report and related to volcanoes covered in this report:

http://libraryphoto.cr.usgs.gov/

http://www.avo.alaska.edu/downloads/searchimg.php

http://pubs.usgs.gov/dds/dds-39/

http://pubs.usgs.gov/dds/dds-40/

http://www.kscnet.ru/ivs/kvert/current/index eng.php

\section{References Cited}

Adleman, J.N., 2006, Response of the Alaska Volcano Observatory to public inquiry concerning the 2006 eruption of Augustine Volcano, Cook Inlet, Alaska: Eos, Fall Meeting Supplement, v. 87, n. 52, Abstract V41F-02.

Beget, J.E., and Kienle, Juergen, 1992, Cyclic formation of debris avalanches at Mount St. Augustine Volcano: Nature, v. 356, no. 6371, p. 701-704, doi: 10.1038/356701a0.

Belousov, A., and Belousova, M., 2001, Eruptive process, effects, and deposits of the 1996 and the ancient basaltic phreatomagmatic eruptions in Karymsky lake, Kamchatka, Russia, in White, J.D., and Riggs, N.R. (eds.), Lacustrine Volcanoclastic Sedimentation, Special Publications of the International Association of Sedimentologists, v. 30, p. 235-260, available at URL: http://www.kscnet.ru/ivs/lavdi/ staff/belousov/lake.pdf.

Bogoyavlenskaya, G.E., Braitseva, O.A., Melekestsev, I.V., Kiriyanov, V.Yu., and Miller, C.D., 1985, Catastrophic eruptions of the directed-blast type at Mount St. Helens, Bezymianny and Shiveluch Volcanoes: Journal of Geodynamics, v. 3, p. 189-218.

Bull, K.F., Vallance, J.W., and Coombs, M.L., 2006, Pyroclastic flows, lahars, and mixed avalanches generated during the 2005-2006 eruption of Augustine Volcano, Alaska: Eos, Fall Meeting Supplement, v. 87, no. 52, Abstract V41F-07.

Cervelli, P.F., Fournier, Tom, Freymueller, J., and Power, J.A., 2006, Ground deformation associated with the precursory unrest and early phases of the January 2006 eruption of Augustine Volcano, Alaska: Geophysical Research Letters, v. 33, 5 p., doi: 10.1029/2006GL027219.

Coombs, M.L., Bull, K.F., Nye, C.J., Schneider, D.J., Vallance, J.W., and Wessels, R., 2006b, Timing, distribution, and character of the proximal products of the 2006 eruption of Augustine Volcano, Alaska: Eos, Fall Meeting Supplement, v. 87, n. 52, Abstract V51C-1689.

Coombs, M.L., Neal, C.A., Wessels, R.L., and McGimsey, R.G., 2006a, Geothermal disruption of summit glaciers at Mount Spurr Volcano, 2004-06: An unusual manifestation of volcanic unrest, in Haeussler, P.J., and Galloway, J.P., Studies by the U.S. Geological Survey in Alaska, 2005: U.S. Geological Survey Professional Paper 1732-B, 33 p., available at URL: http://pubs.usgs.gov/pp/pp1732/pp1732b/.

Dean, K.G., Dehn, Jonathan, Papp, K.R., Smith, Steve, Izbekov, Pavel, Peterson, Rorik, Kearney, Courtney, and Steffke, Andrea, 2004, Integrated satellite observations of the 2001 eruption of Mt. Cleveland, Alaska: Journal of Volcanology and Geothermal Research, v. 135, p. 51-73. 
Dixon, J.P., Prejean, S.G., and Power J.A., 2007, The January 2006 volcano-tectonic earthquake swarm at Mount Martin, Alaska [abs.]: Seismological Research Letters, v. 78, no. 2, p. 255 .

Dixon, J.P., Stihler, S.D., Power, J.A., Tytgat, Guy, Estes, Steve, and, McNutt, S.R., 2006, Catalog of earthquake hypocenters at Alaska volcanoes: January 1 through December 31, 2005: U.S. Geological Survey Open-File Report 2006-1264, 78 p., available at URL: http://pubs.usgs. gov/of/2006/1264.

Doukas, M.P., and McGee, K.A., 2007, A compilation of gas emission-rate data from volcanoes of Cook Inlet (Spurr, Crater Peak, Redoubt, Iliamna, and Augustine) and Alaska Peninsula (Douglas, Fourpeaked, Griggs, Mageik, Martin, Peulik, Ukinrek Maars, and Veniaminof), Alaska, from 1995-2006: U.S. Geological Survey Open-File Report 2007-1400, 13 p., available at URL: http://pubs.usgs.gov/ of/2007/1400/.

Fedotov, S.A., 1998, The 1996 eruption in the Karymsky volcanic center and related events: Special issue of Volcanology and Seismology, v. 19, n. 5, p. 521-767 (L.N. Rykunov, Editor in Chief, Preface and 10 papers, English translation), Gordon \& Breach Science Publishers (ISBN 0742-0463).

Fierstein, Judy, and Hildreth, Wes, 2001, Preliminary volcanohazard assessment for the Katmai volcanic cluster, Alaska: U.S. Geological Survey Open-File Report 00-489, 50 p., available at URL: http://geopubs.wr.usgs.gov/open-file/ of00-489/of00-489.pdf.

Fournier, T.J., and Freymueller, J.T., 2006, Tectonic and volcanic deformation at Veniaminof Volcano Alaska: Chapman Conference on Active Tectonics and Seismic Potential of Alaska, Girdwood, Alaska, May 11-14, 2006.

Gardner, C.A., and Guffanti, M.C., 2006, U.S. Geological Survey's alert notification system for volcanic activity: U.S. Geological Survey Fact Sheet 2006-3139, 4 p., available at URL: http://pubs.usgs.gov/fs/2006/3139/.

Gardner, C.A., Neal, C.A., Waitt, R.B., and Janda, R.J., 1994, Proximal pyroclastic deposits from the 1989-1990 eruption of Redoubt Volcano, Alaska - stratigraphy, distribution, and physical characteristics, in Miller, T.P., and Chouet, B.A. (eds.), The 1989-1990 eruptions of Redoubt Volcano, Alaska, Journal of Volcanology and Geothermal Research, v. 62 , no. 1, p. 213-250.

Girina, O.A., Bogoyavlenskaya, G.E., and Demyanchuk, Yu.V., 1993, Bezymianny eruption of August 2, 1989: Volcanology and Seismology, v. 15, no. 2, p. 135-144 (in Russian).
Gorshkov, G.S., 1970, Catalog of the active volcanoes of the world including solfatara fields. Part VII. Kurile Islands: International Volcanology Association, Via Tasso 199, Napoli, Italy, 99 p.

Ivanov, B.V., Braitseva, O.A., and Zubin, M.I., 1991, Karymsky Volcano, chapter 21, in Fedotov, S.A., and Masurenkov, Yu.P. (eds.), Active volcanoes of Kamchatka, Moscow: Nauka Publishers (Moscow), v. 2, p. 202-203.

Iverson, R.M., Dzurisin, Daniel, Gardner, C.A., Gerlach, T.M., LaHusen, R.G., Lisowski, Michael, Major, J.J., Malone, S.D., Messerich, J.A., Moran, S.C., Pallister, J.S., Qamar, A.I., Schilling, S.P., and Vallance, J.W., 2006, Dynamics of seismogenic volcanic extrusion at Mount St. Helens in 2004-05: Nature, v. 444, November 23, 2006, p. 439-443.

Keith, T.E.C., ed., 1995, The 1992 eruptions of Crater Peak Vent, Mount Spurr Volcano, Alaska: U.S. Geological Survey Bulletin 2139, 220 p.

Khrenov, A.P., Dvigalo, V.N., Kirsanov, I.T., Fedotov, S.A., Gorel'chik, I., and Zharinov, N.A., 1991, Klyuchevskoy Volcano, chapter 6, in Fedotov, S.A., and Masurenkov, Yu.P. (eds.), Active volcanoes of Kamchatka, Moscow: Nauka Publishers (Moscow): v. 1, p. 146-163.

Kirianov, V.Yu., Neal, C.A., Gordeev, E.I., and Miller, T.P., 2002, Kamchatkan Volcanic Eruptions Response Team (KVERT): U.S. Geological Survey Fact Sheet 064-02, 2 p., in English and Russian. Available in English at URL: $\underline{\text { http:// }}$ pubs.usgs.gov/fs/2002/fs064-02/fs064-02.pdf.

Lu, Zhong, 2007, InSAR imaging of volcanic deformation over cloud-prone areas - Aleutian Islands: Photogrammetric Engineering and Remote Sensing, v. 73, no. 3, p. 245-257.

Lu, Zhong, Dzurisin, Daniel, Wicks, C.J., Power, John, Kwoun, O. and Rykhus, R., 2007, Diverse deformation patterns of Aleutian volcanoes from satellite interferometric synthetic aperture radar (InSAR), in: in Eichelberger, John. Gordeev, Evgenii, Kasahara, Minoru, Izbekov, Pavel, and Lees, Jonathan, (eds.), Volcanism and Tectonics of the Kamchatka Peninsula and Adjacent Arcs, American Geophysical Union Monograph Series 172, p. 249-261.

Lu, Zhong, Wicks, Charles, Jr., Dzurisin, Daniel, Power, John, Thatcher, Wayne, and Masterlark, Timothy, 2003, Interferometric synthetic aperture radar studies of Alaska volcanoes: Earth Observation Magazine, v. 12, no. 3, p. 8-18.

McGee, K.A., Doukas, M.P., McGimsey, R.G., Wessels, R.L., and Neal, C.A., 2006, Gas emissions from Augustine Volcano, Alaska 1995-2006: Eos Trans. AGU, 87(52), Fall Meeting Supplement, Abstract V51C-1687. 
McGee, K.A., Doukas, M.P., McGimsey, R.G., Neal, C.A., and Wessels, R.L., 2008, Atmospheric contribution of gas emissions from Augustine Volcano, Alaska during the 2006 eruption: Geophysical Research Letters, v. 35, L03306, doi: 10.1029/2007GL032301, 5 p.

McGimsey, R.G., and Neal, C.A., 1996, 1995 Volcanic activity in Alaska and Kamchatka: Summary of events and response of the Alaska Volcano Observatory: U.S. Geological Survey Open-File Report 96-738, 23 p., available at URL: $\underline{\text { http:// }}$ geopubs.wr.usgs.gov/open-file/of96-738/1995_Summary. pdf.

McGimsey, R.G., Neal, C.A., Dixon, J.P., and Ushakov, Sergey, 2007, 2005 Volcanic activity in Alaska, Kamchatka, and the Kurile Islands: Summary of events and response of the Alaska Volcano Observatory: U.S. Geological Survey Scientific Investigations Report 2007-5269, 94 p., available at URL: http://pubs.usgs.gov/sir/2007/5269/pdf/ sir20075269.pdf.

McGimsey, R.G., Neal, C.A., and Girina, O.A., 2005a, 2001 Volcanic activity in Alaska and Kamchatka: Summary of events and response of the Alaska Volcano Observatory: U.S. Geological Survey Open-File Report 2004-1453, 53 p., available at URL: http://pubs.usgs.gov/of/2004/1453/ of2004-1453.pdf.

McGimsey, R.G., Neal, C.A., and Girina, O.A., 2005b, 2003 Volcanic activity in Alaska and Kamchatka: Summary of events and response of the Alaska Volcano Observatory: U.S. Geological Survey Open-File Report 2005-1310, 58 p., available at URL: http://pubs.usgs.gov/of/2005/1310/ of2005-1310.pdf.

McGimsey, R.G., and Wallace, K.L., 1999, 1997 Volcanic activity in Alaska and Kamchatka: Summary of events and response of the Alaska Volcano Observatory: U.S. Geological Survey Open-File Report 99-448, 42 p. , available at URL: http://geopubs.wr.usgs.gov/open-file/ of99-448/.

Miller, T.P., McGimsey, R.G., Richter, D.H., Riehle, J.R., Nye, C.J., Yount, M.E., and Dumoulin, J.A., 1998, Catalog of the historically active volcanoes of Alaska: U.S. Geological Survey Open-File Report 98-582, 104 p., available at URL: http://www.avo.alaska.edu/downloads/catalog.php.

Motyka, R.J., Liss, S.A., Nye, C.J., and Moorman, M.A., 1993, Geothermal resources of the Aleutian Arc: Alaska Division of Geological \& Geophysical Surveys Professional Report 114, 17 p., 4 sheets, scale 1:1,000,000, available at URL: http://www.dggs.dnr.state.ak.us/pubs/ pubs? reqtype $=$ citation $\& I D=2314$.

National Oceanic and Atmospheric Administration, Federal Aviation Administration, U.S. Geological Survey, 2004, Alaska interagency operating plan for volcanic ash episodes: 29 p.
Neal, C.A., Doukas, M.P., and McGimsey, R.G., 1995b, 1994 Volcanic activity in Alaska: Summary of events and response of the Alaska Volcano Observatory: U.S. Geological Survey Open-File Report 95-271, 19 p., available at URL: http://geopubs.wr.usgs.gov/open-file/ of95-271/.

Neal, C.A., and McGimsey, R.G., 1997, 1996 Volcanic activity in Alaska and Kamchatka: Summary of events and response of the Alaska Volcano Observatory: U.S. Geological Survey Open-File Report 97-433, 34 p., available at URL: http:// pubs.er.usgs.gov/usgspubs/ofr/ofr97433.

Neal, C.A., McGimsey, R.G., Dixon, Jim, and Melnikov, Dmitry, 2005b, 2004 Volcanic activity in Alaska and Kamchatka: Summary of events and response of the Alaska Volcano Observatory: U.S. Geological Survey Open-File Report 2005-1308, 67 p., available at URL: http://pubs.usgs. gov/of/2005/1308/of2005-1308.pdf.

Neal, C.A., McGimsey, R.G., and Doukas, M.P., 1996, 1993 Volcanic activity in Alaska: Summary of events and response of the Alaska Volcano Observatory: U.S. Geological Survey Open-File Report 96-24, 21 p., available at URL: http://geopubs.wr.usgs.gov/open-file/of96-24/.

Neal, C.A., McGimsey, R.G., Gardner, C.A., Harbin, M.L., and Nye, C.J., 1995a, Tephra-fall deposits from the 1992 eruptions of Crater Peak, Mount Spurr Volcano, Alaska: Preliminary report on distribution, stratigraphy and composition, in Keith, T.E.C. (ed.), The 1992 eruptions of Crater Peak vent, Mount Spurr Volcano, Alaska: U.S. Geological Survey Bulletin 2139, chap. 7, p. 65-79, available at URL: http://www.avo.alaska.edu/pdfs/B2139 p65to79.pdf.

Neal, C.A., McGimsey, R.G., and Girina, O.A., 2003, 1998 Volcanic activity in Alaska and Kamchatka: Summary of events and response of the Alaska Volcano Observatory: U.S. Geological Survey Open-File Report 03-423, 35 p., available at URL: http://pubs.usgs.gov/of/2003/of03-423/.

Neal, C.A., McGimsey, R.G., and Girina, O.A., 2005a, 2002 Volcanic activity in Alaska and Kamchatka: Summary of events and response of the Alaska Volcano Observatory: U.S. Geological Survey Open-File Report 2004-1058, 51 p., available at URL: http://pubs.usgs.gov/of/2004/1058/.

Nichols, D.R., and Yehle, L.A., 1961, Analyses of gas and water from two mineral springs in the Copper River basin, Alaska, in Short papers in the geologic and hydrologic sciences, articles 293-435: Geological Survey Research 1961: U.S. Geological Survey Professional Paper 424-D, p. D191-D194.

Nye, C.J., and Turner, D.L., 1990, Petrology, geochemistry, and age of the Spurr volcanic complex, eastern Aleutian arc: Bulletin of Volcanology, v. 52, no. 3, p. 205-226. 
Ponomareva, V.V., Pevzner, M.M., and Melekestsev, I.V., 1998, Large debris avalanches and associated eruptions in the Holocene eruptive history of Shiveluch Volcano, Kamchatka, Russia: Bulletin of Volcanology, v. 59, no. 7, p. 490-505.

Power, J.A, 2004, Renewed unrest at Mount Spurr Volcano, Alaska: Eos, v. 85, no. 43, p. 434.

Power, J.A., Nye, C.J., Coombs, M.L., Wessels, R.L., Cervelli, P.F., Dehn, J., Wallace, K.L., Freymueller, J.T., and Doukas, M.P., 2006, The reawakening of Alaska's Augustine Volcano: Eos, v. 87, no. 37, p. 373-377.

Richter, D.H., Rosenkrans, D.S., and Steigerwald, M.J., 1995, Guide to the volcanoes of the western Wrangell Mountains, Alaska-Wrangell-St. Elias National Park and Preserve: U.S. Geological Survey Bulletin 2072, 31 p.

Richter, D.H., Symonds, R.B., Rosenkrans, D.S., McGimsey, R.G., Evans, W.C., and Poreda, R.J., 1998, Report on the 1997 activity of Shrub Mud Volcano, Wrangell-St. Elias National Park and Preserve, south-central Alaska: U.S. Geological Survey Open-File Report 98-128, 13 p.

Riehle, J.R., 1985, A reconnaissance of the major Holocene tephra deposits in the upper Cook Inlet region, Alaska: Journal of Volcanology and Geothermal Research, v. 26, no. $1-2$, p. 37-74.

Rybin, A.V., Karagusov, Y.V., Izbekov, Pavel, Terentyev, N.S., Guryanov, V.B., Neal, C.A., and Dean, Ken, 2004, Status of monitoring active volcanoes of the Kurile Islands: Present and future, in Proceedings of the Second International Conference on Volcanic Ash and Aviation Safety. Published by the Office of the Federal Coordinator for Meteorological Services and Supporting Research, p. 61-66.

Searcy, Craig, Dean, Ken, and Stringer, William, 1998, PUFF: A high-resolution volcanic ash tracking model: Journal of Volcanology and Geothermal Research, v. 80, no. 1-2, p. $1-16$.
Siebert Lee, and Simkin, Tom, 2002-, Volcanoes of the World: An illustrated catalog of Holocene volcanoes and their eruptions: Smithsonian Institution, Global Volcanism Program Digital Information Series, GVP-3, available at URL: http://www.volcano.si.edu/world/.

Simkin, Tom, and Siebert, Lee, 1994, Volcanoes of the World [2 $2^{\text {nd }}$ ed.]: Tucson, Arizona, Geoscience Press, Inc., 349 p.

Smithsonian Institution, 2005, Ebeko: Bulletin of Global Volcanism Network, v. 30, no. 6 (BGVN 30:60).

Sorey, M.L., Werner, Cindy, McGimsey, R.G., and Evans, W.C., 2000, Hydrothermal activity and carbon-dioxide discharge at Shrub and upper Klawasi mud volcanoes, Wrangell Mountains, Alaska: U.S. Geological Survey Water-Resources Investigations Report 00-4207, 12 p.

Turner, D.L., and Wescott, E.M. (eds.), 1986, Geothermal energy resource investigations at Mt. Spurr, Alaska: University of Alaska Fairbanks, Geophysical Institute Report UAGR-308, p. 41-65, 1 sheet, scale 1:2,860.

Voight, Barry, Glicken, Harry, Janda, R.J., and Douglass, P.M., 1981, Catastrophic rockslide avalanche of May 18, in Lipman, P.W., and Mullineaux, D.R., (eds.), The 1980 eruptions of Mount St. Helens, Washington: U.S. Geological Survey Professional Paper 1250, p. 347-378.

Wallace, K.L., Neal, C.A., McGimsey, R.G., 2006, Timing, distribution, and character of tephra fall from the 2005-2006 eruption of Augustine Volcano, Alaska: Eos, Transactions, American Geophysical Union 87(52), Fall Meeting Supplement, Abstract V41F-06.

Zharinov, N.A., Bogoyavlenskaya, G.E., Khubunaya, S.A., and Demyanchuk Yu.V., 1995, A new eruption cycle of Shiveluch Volcano, 1980-1993: Volcanol Seismol 17: p. 21-30 (in Russian). 


\section{Glossary of Selected Terms and Acronyms}

\author{
AAWU: "Alaska Aviation Weather Unit" of \\ the National Weather Service. \\ ‘’a: Hawaiian term for lava flows \\ characterized by a rough, jagged, blocky \\ surface.
}

ADGGS: Alaska Division of Geological \& Geophysical Surveys.

ADT: "Alaska Daylight Time"; UTC -8 hours ADT.

AEIC: Alaska Earthquake Information Center.

AFTN: Aeronautical Fixed Telecommunications Network.

andesite: volcanic rock composed of about 53-63 percent silica $\left(\mathrm{SiO}_{2}\right.$, ; an essential constituent of most minerals found in rocks).

ash: fine fragments (less than 2 millimeters across) of lava or rock formed in an explosive volcanic eruption.

ASL: above sea level.

AST: "Alaska Standard Time"; UTC -9 hours AST.

ASTER: Advanced Spaceborne Thermal Emission and Reflection Radiometer.

AVHRR: "Advanced Very High Resolution Radiometer"; AVHRR provides one form of satellite imagery.

AVO: Alaska Volcano Observatory.

basalt: general term for dark-colored igneous rock, usually extrusive, containing about 45-52 weight percent silica $\left(\mathrm{SiO}_{2}\right.$, an essential constituent of most minerals found in rocks).

bomb: boulder-size chunk of partly solidified lava explosively ejected from a volcano.

caldera: a large, roughly circular depression usually caused by volcanic collapse or explosion.

CAVW: Smithsonian Institute's "Catalog of Active Volcanoes of the World" (Simkin and Siebert, 1994). cinder cone: small, steep-sided conical hill built mainly of cinder, spatter, and volcanic bombs.

COSPEC: "Correlation Spectrometer," a device for measuring sulfur-dioxide emissions.

CWSU: "Center Weather Service Unit" of the National Oceanic and Atmospheric Administration, stationed at the Air Route Traffic Control Center.

FAA: Federal Aviation Administration.

fallout: a general term for debris which falls to the Earth from an eruption cloud.

fault: A fracture along which the blocks of the Earth's crust on either side have moved relative to one another parallel to the fracture.

FIR: Flight Information Region.

fissure: a roughly linear or sinuous crack or opening on a volcano; a type of vent which commonly produces lava fountains and flows.

FLIR: "Forward Looking Infrared

Radiometer," used to delineate objects of different temperature.

fumarole: a small opening or vent from which hot gases are emitted.

glaciolacustrine: pertaining to sediments deposited in glacial lakes, and resulting landforms.

GMS: Geostationary Meteorological Satellite.

GOES: Geostationary Operational

Environmental Satellite.

GPS: Global Positioning System.

GVN: "Global Volcanism Network" of the Smithsonian Institution.

Holocene: geologic epoch extending from the present to 10,000 years ago.

IMGG: Russian "Institute of Marine Geology and Geophysics.”

incandescent: glowing red or orange due to high temperature. 
InSAR: Interferometric Synthetic Aperture Radar.

intracaldera: refers to something within the caldera.

ISS: International Space Station.

IVS: Russian "Institute of Volcanology and Seismology."

JMA: Japanese Meteorological Agency.

JPEG: "Joint Photographic Experts Group," type of digital photographic file.

Ka: thousands of years before the present.

KDT: "Kamchatkan Daylight Time" equals ADT +21 hrs.

KBGS: Kamchatka Branch of Geophysical Surveys.

KEMSD: Russian "Kamchatka Experimental and Methodical Seismological Department."

KST: "Kamchatka Standard Time" equals AST + 21 hours.

KVERT: Kamchatkan Volcanic Eruption Response Team.

lapilli: pyroclasts or volcanic fragments that are between $2 \mathrm{~mm}$ and $64 \mathrm{~mm}$ in diameter.

lava: molten material at the Earth's surface. magma: molten material below the surface of the Earth.

MODIS: Satellite-based "Moderateresolution Imaging Spectroradiometer."

MWO: Meteorological Watch Office.

NASA: National Aeronautics and Space Administration.

NOAA: National Oceanic and Atmospheric Administration.

NOPAC: North Pacific air route corridors.

NOTAM: "Notice to Airmen," a notice containing information [not known sufficiently in advance to publicize by other means] concerning the establishment, condition, or change in any component [facility, service, or procedure of, or hazard in the National Airspace System] the timely knowledge of which is essential to personnel concerned with flight operations.

NPS: National Park Service.

NWS: National Weather Service.
OMI: Ozone Mapping Instrument.

phreatic activity: an explosive eruption caused by the sudden heating of ground water as it comes in contact with hot volcanic rock or magma.

phreatic ash: fine fragments of volcanic rock expelled during phreatic activity; this ash usually is derived from existing rock and not from new magma.

PIREP: "Pilot Weather Report"; a report of meteorological phenomena encountered by aircraft in flight.

pixel: contraction of "picture element." A pixel is one of the many discrete rectangular elements that form a digital image or picture on a computer monitor or stored in memory. In a satellite image, resolution describes the size of a pixel in relation to area covered on the ground. More pixels per unit area on the ground means a higher resolution.

PK: "Petropavlovsk"; capital city of Kamchatka, Russia.

Pleistocene: geologic epoch extending from 2-3 million years ago to approximately 10,000 years before present.

PUFF: a volcanic ash tracking model (see at URL: http://puff.images.alaska.edu/ monitoring.shtml).

pyroclast: an individual particle ejected during a volcanic eruption; usually classified by size, for example, ash, lapilli.

regional earthquake: earthquake generated by fracture or slippage along a fault; not caused by volcanic activity.

RFE: Russian Far East.

SAB: "Synoptic Analysis Branch" of NOAA.

SAR: Synthetic Aperture Radar.

satellite cone: a subsidiary volcanic vent located on the flank of a larger volcano.

seismic swarm: a flurry of closely spaced earthquakes or other ground shaking activity; often precedes an eruption.

shield volcano: a broad, gently sloping volcano usually composed of fluid lava flows of basalt composition (for example, Mauna Loa, Hawaii).

SI: Internation System of Units. 
SIGMET: SIGnificant METeorological information statement, issued by NWS.

Stratovolcano: Also called a stratocone or composite cone, a steep-sided volcano, usually conical in shape, built of interbedded lava flows and fragmental deposits from explosive eruptions.

Strombolian: type of volcanic eruption characterized by intermittent bursts of fluid lava, usually basalt, from a vent or crater as gas bubbles rise through a conduit and burst at the surface.

sub-plinian: style of explosive eruptions characterized by vertical eruption columns and widespread dispersal of tephra.

SVA: Suspect Volcanic Activity.

SVERT: "Sakhalin Volcanic Eruption Response Team" monitors and reports on Kurile Island volcanoes.

SWIR: Short Wave Infrared.

tephra: a general term covering all fragmental material expelled from a volcano (ash, bombs, cinders, etc.).

TFR: "Temporary Flight Restriction," issued by FAA.

TIR: Thermal Infrared.
UAFGI: University of Alaska Fairbanks Geophysical Institute.

USCG: United States Coast Guard.

USFWS: United States Fish and Wildlife Service.

USGS: United States Geological Survey.

UTC: "Coordinated Universal Time"; same as Greenwich Mean Time (GMT).

UUA: Urgent pilot report.

VAAC: Volcanic Ash Advisory Center

VAA: Volcanic Ash Advisory.

vent: an opening in the earth's surface through which magma erupts or volcanic gasses are emitted.

VNIR: Very Near Infrared.

volcano-tectonic earthquakes: earthquakes generated within or near a volcano from brittle rock failure resulting from strain induced by volcanic processes.

Vulcanian: style of explosive eruption consisting of repeated, violent ejection of incandescent fragments of viscous lava, usually in the form of blocks, along with volcanic ash. Sometimes, Vulcanian eruptions involve water mixing with erupting magma. 
This page intentionally left blank. 


\section{Appendix 1. Level of Concern Color Code for Volcanic Activity Used in Alaska (until October 1, 2006) and Kamchatka.}

[After October 1, AVO began using a new alert system described in appendix 2. KVERT continues to use this format as of late 2007]

\section{Level of Concern Color Code: Generic}

To more concisely describe our level of concern about possible or ongoing eruptive activity at an Alaskan volcano, the Alaska Volcano Observatory (AVO) uses the following color-coded classification system. Definitions of the colors reflect AVO's interpretations of the behavior of the volcano. Definitions are listed below followed by general descriptions of typical activity associated with each color.

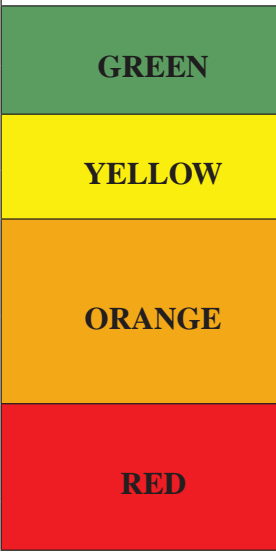

No eruption anticipated.

Volcano is in quiet "dormant" state.

An eruption is possible in the next few weeks and may occur with little or no additional warning.

Small earthquakes detected locally and (or) increased levels of volcanic gas emissions.

Explosive eruption is possible within a few days and may occur with little or no warning. Ash plume(s) not expected to reach 25,000 feet above sea level.

Increase numbers of local earthquakes. Extrusion of a lava dome or lava flows (non-explosive eruption) may be occurring.

Major explosive eruption expected within 24 hours. Large ash plume(s) expected to reach at least 25,000 feet above sea level.

Strong earthquake activity detected even at distant monitoring stations. Explosive eruption may be in progress. 
This page intentionally left blank. 


\section{Appendix 2. Volcano Alert Levels and Revised Aviation Color Codes Used by United States Observatories.}

In the fall of 2006, AVO implemented a new scheme to describe the level of activity at Alaskan volcanoes. This was part of a national effort to bring consistency across the various United States Volcano Observatories (Gardner and Guffanti, 2006). New terms, defined below, are assigned based on instrumental and visual monitoring data and the known history and potential hazards of each volcano.

Alert levels address the overall activity at the volcano, not just the hazard to aviation. There may be situations where a volcano is producing lava flows that are dangerous on the ground and merit a WATCH or WARNING, however, the hazard to aviation is minimal. Alert levels announcements contain additional explanation of volcanic activity and expected hazards where possible.

\begin{tabular}{|c|l|}
\hline \multicolumn{2}{|c|}{ Alert Levels } \\
\hline NORMAL & $\begin{array}{l}\text { Typical background activity of a volcano in a non-eruptive state. } \\
\text { Or, after a change from a higher level: } \\
\text { Volcanic activity considered to have ceased and volcano reverted to its normal, non-eruptive state }\end{array}$ \\
\hline ADVISORY & $\begin{array}{l}\text { Elevated unrest above known background activity. } \\
\text { Or, after a change from a higher level: } \\
\text { Volcanic activity has decreased significantly but continues to be closely monitored for possible renewed increase. }\end{array}$ \\
\hline WATCH & Volcano is exhibiting heightened or escalating unrest with increased potential for eruptive activity. \\
& Or: \\
& A minor eruption is underway that poses limited hazards. \\
\hline WARNING & Highly hazardous eruption underway or imminent. \\
\hline
\end{tabular}

\section{Level of Concern Codes for Aviation}

AVO will continue to use the color-coded level of concern designation that has been in place since 1990. Colors will now reflect only the hazards posed to the aviation community. Definitions of each color have changed slightly. Typically, this means that color codes indicate the likelihood or presence of airborne ash and ash clouds that threaten aircraft.

\begin{tabular}{|l|l|}
\hline \multicolumn{1}{|c|}{ GREEN } & $\begin{array}{l}\text { Volcano is in a normal, non-eruptive state. } \\
\text { Oolcanic activity considered to have ceased and volcano reverted to its normal, non-eruptive state }\end{array}$ \\
\hline YELLOW & $\begin{array}{l}\text { Volcano is exhibiting signs of elevated unrest above known background levels. } \\
\text { Or, after a change from a higher level: } \\
\text { Volcanic activity has decreased significantly but continues to be closely monitored for possible renewed increase. }\end{array}$ \\
\hline ORANGE & $\begin{array}{l}\text { Or: } \\
\text { Volcano is exhibiting heightened unrest with increased likelihood of eruption. }\end{array}$ \\
\hline RED & $\begin{array}{l}\text { Eruption is forecast to be imminent with significant emission of ash into the atmosphere likely. } \\
\text { Eruption is underway with significant emission of ash into the atmosphere. }\end{array}$ \\
\hline
\end{tabular}


This page intentionally left blank. 
Manuscript approved for publication, November 3, 2008

Prepared by the USGS Publishing Network,

Bill Gibbs

Linda Rogers

For more information concerning the research in this report, contact the Director, Alaska Science Center

U.S. Geological Survey

4210 University Dr.

Anchorage, Alaska 99508-4650

http://alaska.usgs.gov 


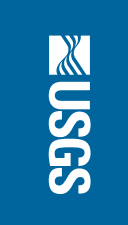

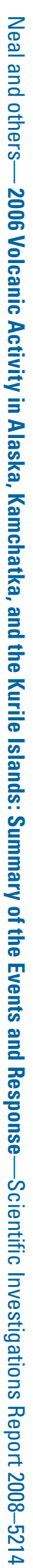

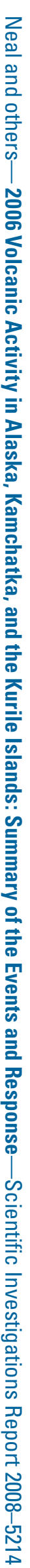

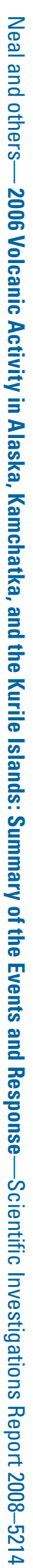

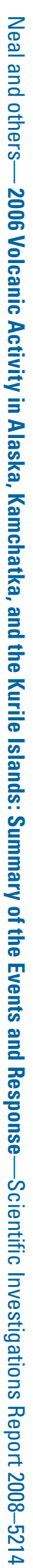

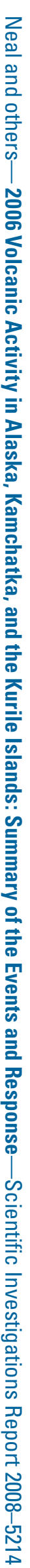

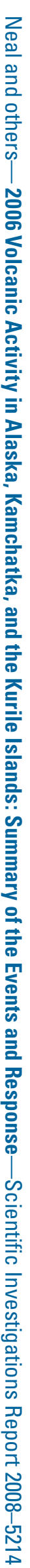

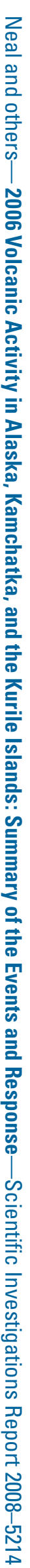

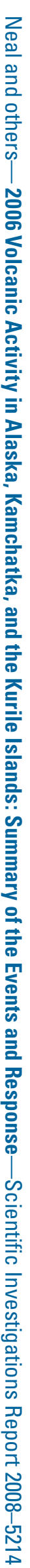

9 Printed on recycled paper 